UNIVERSIDADE DE SÃO PAULO

ESCOLA DE EDUCAÇÃO FÍSICA E ESPORTE

\title{
O PORTFÓLIO COMO UMA POSSIBILIDADE DE INTERVENÇÃO PEDAGÓGICA EM EDUCAÇÃO FÍSICA
}

Luciene Farias de Melo

SÃO PAULO

2008 


\title{
O PORTFÓLIO COMO UMA POSSIBILIDADE DE INTERVENÇÃO PEDAGÓGICA EM EDUCAÇÃO FÍSICA
}

\author{
LUCIENE FARIAS DE MELO
}

\begin{abstract}
Dissertação apresentada à Escola de Educação Física e Esporte da Universidade de São Paulo, como requisito parcial para obtenção do título de Mestre em Educação Física.
\end{abstract}


Melo, Luciene Farias de

O portfólio como uma possibilidade de intervenção pedagógica em educação física / Luciene Farias de Melo. - São Paulo : [s.n.], 2008.

xiii, 311p.

Dissertação (Mestrado) - Escola de Educação Física e Esporte da Universidade de São Paulo.

Orientador: Prof. Dr. Osvaldo Luiz Ferraz.

1. Educação Física Escolar I. Título. 


\section{AGRADECIMENTOS}

À minha mãe, Maria Dolores, meu pai, Josenildo, e minhas irmãs Érica, Roberta e Daniela, pelo apoio e compreensão em todos os momentos de minha vida e por me ensinarem a acreditar que quando se quer algo é somente ir em busca.

Ao meu marido, Eduardo Guida, pelo incentivo, apoio e paciência.

À minha cunhada, Andréa Guida, pelas sugestões de revisão em algumas partes do trabalho.

Ao Prof. Dr. Osvaldo L. Ferraz, pessoa fundamental para que toda essa trajetória se tornasse real, pois me ensinou, sobretudo, a acreditar mais em mim e contribuiu muito para meu processo de aprendizagem.

À banca examinadora, pessoas ilustres e amigas que participam no momento decisivo deste trabalho. Registro aqui meus agradecimentos e minha admiração pelo Prof. Dr. Luiz Dantas e, em especial, pela Profa. Dra. Vilma Nista-Píccolo, que foi quem me abriu as portas para a vida acadêmica.

Aos muitos professores que colaboraram para a aprendizagem neste estudo, especialmente a Profa. Dra. Kátia Rúbio e o Prof. Dr. Nilson José Machado.

Aos alunos que participaram da pesquisa, agradeço o carinho e a disposição que tiveram durante o trabalho.

À instituição de ensino em que foi desenvolvida a pesquisa de campo, pelo apoio de todos os que estiveram presentes durante o trabalho.

Aos amigos, que cruzam nosso caminho e passam a compartilhar momentos importantes de nossa vida. Enfrento a dura tarefa de listar apenas alguns nomes: Profa. Dra. Elaine Prodócimo, Profa. Dra. Carmem Brandl, Profa. Dra. Greice K. Oliveira, Prof. Dr. Marcos G. Neira, Ana Leite, Rodrigo e todos os integrantes do LAPEM. Em especial, Simone Azevedo, pelo apoio e as 
reuniões que me ajudaram a desenvolver a proposta de estudo no colégio, e Profa. Dra. Tatiana Zylberbergue, a quem admiro por sua competência acadêmica, agradecendo o incentivo e a ajuda na organização de minhas idéias e palavras durante a construção do trabalho. 
RESUMO

\title{
O PORTFÓLIO COMO UMA POSSIBILIDADE DE INTERVENÇÃO PEDAGÓGICA EM EDUCAÇÃO FÍSICA
}

\author{
Autora: LUCIENE FARIAS DE MELO \\ Orientador: PROF. DR. OSVALDO LUIZ FERRAZ
}

O objetivo deste trabalho é investigar as possibilidades do portfólio na Educação Física escolar, por meio de uma intervenção pedagógica, para subsidiar uma discussão através da interpretação e análise de indícios extraídos dos registros dos seguintes participantes: a professora-pesquisadora e 23 alunos do quarto ano do Ensino Fundamental de um colégio particular da cidade de Guarulhos. Trata-se de pesquisa qualitativa, baseada na modalidade de pesquisa: paradigma indiciário. As fontes primárias foram o portfólio dos alunos e o diário da professora-pesquisadora. O estudo mostra que planejar, vivenciar, refletir e registrar a experiência de ensino com o portfólio contribuiu positivamente para a formação da professora-pesquisadora: tanto auxiliou a prática pedagógica de avaliação como melhorou sua competência de investigadora em estudos de enfoque qualitativo. Além disso, permitiu que as noções relativas ao processo de ensino e avaliação fossem reelaboradas em um movimento dialógico entre a teoria e a prática. Favoreceu a percepção de modificações na relação entre a professora e os alunos, com aumento da participação deles durante a avaliação, tornando-se mais conscientes de suas responsabilidades diante da aprendizagem, da identificação das dificuldades e de como fazer para melhorá-las. Em síntese, a experiência propiciou aprendizagem docente e discente. Todavia, a avaliação dos resultados aponta a necessidade de se criarem condições nas escolas para o professor 
implementar a proposta em suas aulas; do ponto de vista da pesquisa-ação, destaca-se a dificuldade de se distanciar da própria prática.

Palavras-chave: avaliação; portfólio; Educação Física escolar. 


\begin{abstract}
THE PORTFOLIO AS A POSSIBILITY OF PEDAGOGICAL INTERVENTION IN THE PHYSICAL EDUCATION IN SCHOOLS
\end{abstract}

\author{
Author: LUCIENE FARIAS DE MELO \\ Adviser: PROF. DR. OSVALDO LUIZ FERRAZ
}

The objective of this work is to investigate the possibilities of using portfolio in physical education classes through pedagogical intervention, aiming to provide a discussion after analyzing and interpreting clues extracted from notes from a teacher-researcher and 23 students from the forth year of the elementary school, studying in a private school in the city of Guarulhos. This work follows a model of qualitative research, using method such as evidential paradigm. The notes in the students' portfolio and the teacher's diary were used as instruments in this research. The study shows that planning, living, reflecting and registering the teaching experience with a portfolio contributed positively to the formation of the teacher-researcher: it helped the assessment pedagogical practice and improved the competence of investigation in qualitative focus. Besides it allowed that the teaching and evaluation processes could be reorganized in a dialogic movement between theory and practice. It also supported some changes in the teacher students relation, within their participation during the assessment process when they became more aware of their responsibility as learners and the identification of their difficulties and what to do to improve. Summing up, the experience provided learning for both students and teacher. However, the results point out the need to create conditions in schools so that the teachers could implement the proposals in their 
classes. From the research-action point of view, it was made clear indeed, that the teacher-researcher found difficult to keep a distance of her own practice.

Key words: assessment, portfolio, physical education 
TABELA 1 - Aula 1 - Observações da professora......................................113

TABELA 2 - Aula 2 - Observações da professora.......................................117

TABELA 3 - Aula 3 - Observações da professora.......................................125

TABELA 4 - Aula 4 - Observações da professora........................................132

TABELA 5 - Aula 5 - Observações da professora........................................134

TABELA 6 - Aula 6 - Observações da professora.........................................149

TABELA 7 - Aula 7 - Observações da professora........................................157

TABELA 8 - Resultados da primeira coleta do portfólio..................................161

TABELA 9 - Primeira auto-avaliação e avaliação das aulas...........................163

TABELA 10 - Aula 11 - Observações da professora.....................................172

TABELA 11 - Aula 12 - Observações da professora.....................................180

TABELA 12 - Aula 13 - Observações da professora.....................................187

TABELA 13 - Aula 14 - Observações da professora....................................193

TABELA 14 - Aula 17 - Observações da professora...................................197

TABELA 15 - Aula 18 - Observações da professora.....................................202

TABELA 16 - Aula 19 - Observações da professora.....................................211

TABELA 17 - Aula 20 - Observações da professora......................................217

TABELA 18 - Aula 21 - Observações da professora....................................224

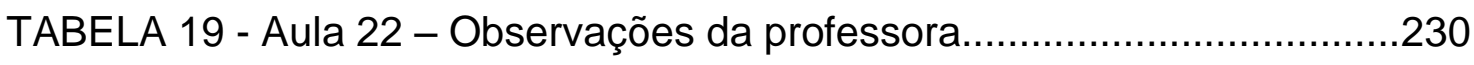

TABELA 20 - Aula 23 - Observações da professora......................................236

TABELA 21 - Resultados da segunda coleta do portfólio...............................246

TABELA 22 - Segunda auto-avaliação e avaliação das aulas..........................247

TABELA 23 - Primeira pergunta norteadora - Aula 1 .................................252

TABELA 24 - Primeira pergunta norteadora - Aula 2....................................253

TABELA 25 - Primeira pergunta norteadora - Aula 3.................................258

TABELA 26 - Primeira pergunta norteadora - Aula 4..................................261

TABELA 27 - Primeira pergunta norteadora - Aula 5..................................265 
TABELA 28 - Segunda pergunta norteadora - Aula 3..................................275

TABELA 29 - Segunda pergunta norteadora - Aula 5...................................275

TABELA 30 - Segunda pergunta norteadora - Aula 6.................................275

TABELA 31 - Segunda pergunta norteadora - Aula 7 .................................276

TABELA 32 - Segunda pergunta norteadora - Aula 11...............................276

TABELA 33 - Segunda pergunta norteadora - Aula 12...............................278

TABELA 34 - Segunda pergunta norteadora - Aula 13 ...............................278

TABELA 35 - Segunda pergunta norteadora - Aula 14 ................................279

TABELA 36 - Segunda pergunta norteadora - Aula 18................................280

TABELA 37 - Segunda pergunta norteadora - Aula 19...............................280

TABELA 38 - Segunda pergunta norteadora - Aula 20...............................280

TABELA 39 - Segunda pergunta norteadora - Aula 21................................281

TABELA 40 - Segunda pergunta norteadora - Aula 22...............................282

TABELA 41 - Segunda pergunta norteadora - Aula 23.................................286

TABELA 42 - Aula 8 - Primeira auto-avaliação - Questões 1 e 2...................285

TABELA 43 - Aula 8 - Primeira auto-avaliação - Questões 3 e 4..................28

TABELA 44 - Aula 8 - Primeira auto-avaliação - Questões 5 e 6 ...................291

TABELA 45 - Aula 25 - Segunda auto-avaliação - Questões 1 e 2................293

TABELA 46 - Aula 25 - Segunda auto-avaliação - Questões 3 e 4 ...............296

TABELA 47 - Aula 25 - Segunda auto-avaliação - Questões 5 e 6 ..............298

TABELA 48 - Quarta pergunta norteadora - Observações sobre a primeira

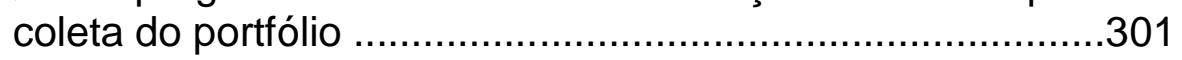

TABELA 49 - Quarta pergunta norteadora - Observações sobre a segunda coleta do portfólio dos alunos............................................. 304

TABELA 50 - Quinta pergunta norteadora - Aula 2 - Observações sobre os registros dos alunos

TABELA 51 - Quinta pergunta norteadora - Aula 2 - Observações sobre os registros dos alunos .307

TABELA 52 - Quinta pergunta norteadora - Aula 5 - Observações sobre os registros dos alunos. .307

TABELA 53 - Sexta pergunta norteadora - Aula 13 - Observações sobre os registros dos alunos. .310 


\section{LISTA DE ANEXOS}

Página

ANEXO I Planejamento da proposta de estudo.....................................105

ANEXO II Diário da professora-pesquisadora............................................112

ANEXO III Indícios da primeira pergunta norteadora..................................252

ANEXO IV Indícios da segunda pergunta norteadora.................................275

ANEXO V Indícios da terceira pergunta norteadora....................................285

ANEXO VI Indícios da quarta pergunta norteadora........................................301

ANEXO VII Indícios da quinta pergunta norteadora.....................................307

ANEXO VIII Indícios da sexta pergunta norteadora ........................................309 
SUMÁRIO

Página

LISTA DE TABELAS........................................................... vii

LISTA DE ANEXOS............................................................

RESUMO

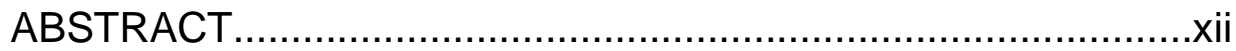

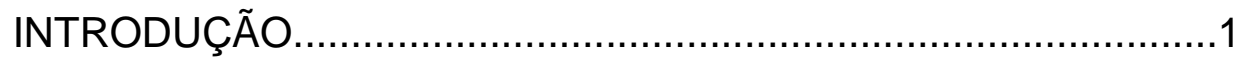

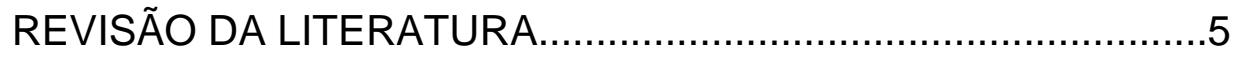

2.1 Vestígios históricos sobre a avaliação da aprendizagem no contexto

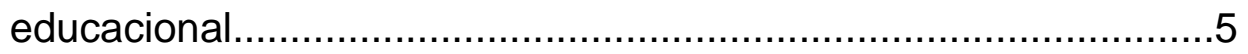

2.2 Avaliação em Educação Física escolar.......................................14

2.3 Pesquisas recentes sobre a avaliação em Educação Física

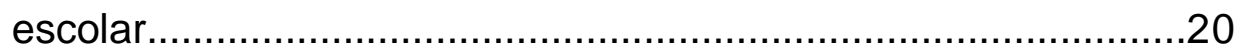

2.3.1 Avaliação como verificação da aprendizagem................................

2.3.2 Ambigüidade no discurso dos professores................................27

2.3.3 Mudanças na escolha do objeto avaliado ...................................28

2.3.4 A nota como instrumento de poder.............................................

2.3.5 Necessidade de formação dos professores...................................30

3

O PORTFÓLIO COMO UMA POSSIBILIDADE DE INTERVENÇÃO PEDAGÓGICA EM EDUCAÇÃO FÍSICA.....................................32

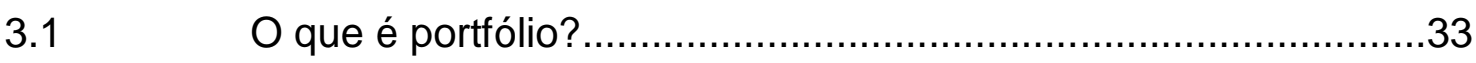

3.2 Como o portfólio deve ser utilizado? ...........................................36

3.3 Aspectos da construção do portfólio..........................................38

3.4 A atuação do professor no trabalho com o portfólio......................44

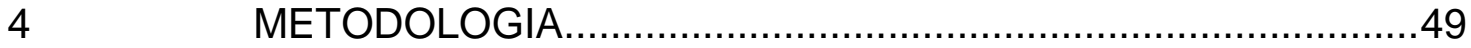

4.1 A pesquisa qualitativa como enfoque metodológico ....................50

4.2 A modalidade de pesquisa utilizada.......................................52

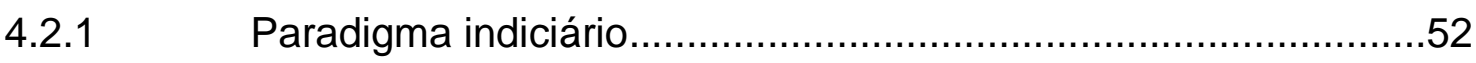

4.3 O espaço, o tempo e os atores da investigação...........................54 
4.3.1 O espaço da investigação....................................................

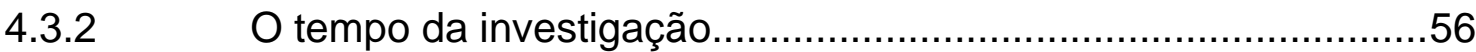

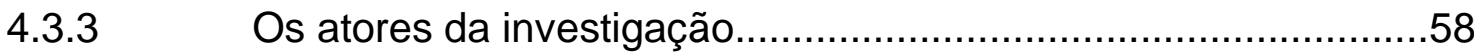

4.4 Os instrumentos de coleta e os procedimentos de análise dos

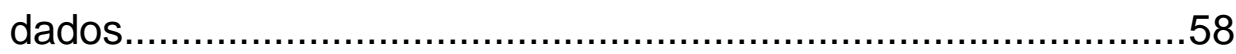

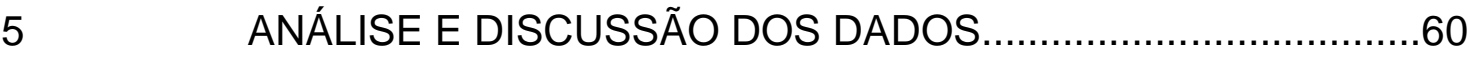

5.1 A primeira pergunta norteadora: $O$ portfólio revelou os conhecimentos trabalhados em aula?..........................................60

5.2 A segunda pergunta norteadora: O portfólio possibilitou aos alunos identificar as dificuldades de aprendizagem e como fazer

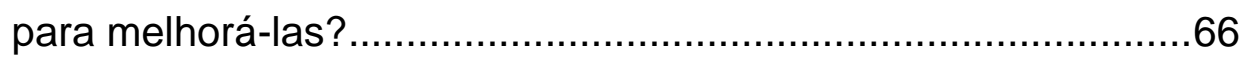

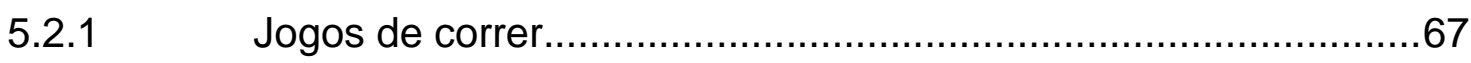

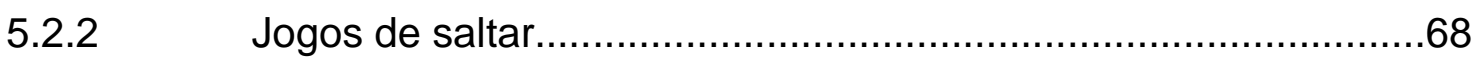

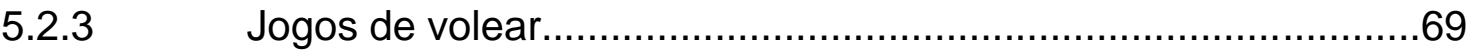

5.2.4 Atitudes que favorecem a solução de problemas por meio do

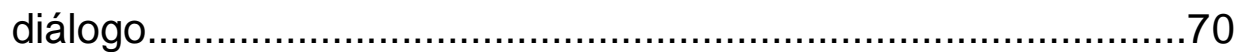

5.2.5 A atitude de persistir frente às dificuldades................................70

5.3 A terceira pergunta norteadora: A auto-avaliação como mais um instrumento inserido no portfólio dos alunos possibilitou a aprendizagem dos aspectos relacionados à postura de

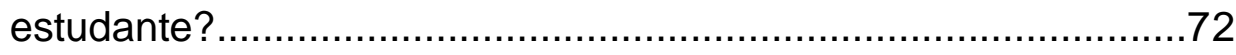

5.3.1 Momentos em que houve dificuldade e a aquisição de

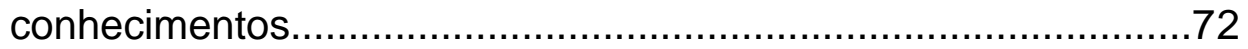

5.3.2 A importância da turma em sua aprendizagem e sua participação na aprendizagem da turma......................................................73

5.3.3 Apontamentos das tarefas que deixou de realizar.......................73

5.3.4 Pesquisa sobre outros materiais e reconhecimento do que aprendeu com as informações encontradas..................................73

5.3.5 Apontamentos dos aspectos que precisam ser melhorados.......74

5.4 A quarta pergunta norteadora: $O$ portfólio possibilitou à professora reflexão sobre sua prática pedagógica?........................................76

5.5 A quinta pergunta norteadora: $O$ portfólio indicou as dificuldades da professora no processo de ensino e aprendizagem? ..............81

5.5.1 Falta de experiência com o portfólio..........................................81 
5.5.2 Necessidade de discutir o trabalho.........................................81

5.5.3 Problemas na prática pedagógica.........................................82

5.5.4 Falta de comprometimento de alguns alunos............................83

5.6 A sexta pergunta norteadora: O portfólio possibilitou à professora conhecimento sobre como melhorar as dificuldades relacionadas

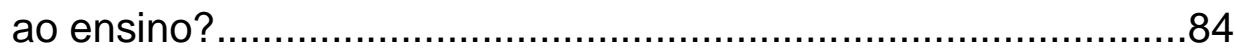

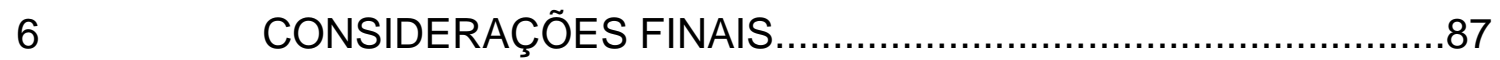

REFERÊNCIAS BIBLIOGRÁFICAS...................................... 98

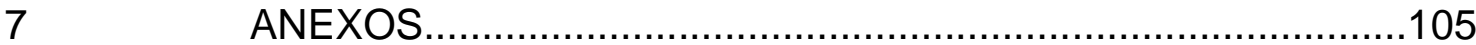




\section{INTRODUÇÃO}

Esta pesquisa está referenciada em minha experiência pedagógica como professora de Educação Física em colégios da rede particular de ensino de Guarulhos (SP), desde 1998. Dessa data até os dias atuais tenho vivenciado problemas significativos na área, principalmente no que se refere à avaliação da aprendizagem dos alunos.

A avaliação é geralmente executada nas aulas de Educação Física como um mecanismo burocrático, que se encerra na atribuição de nota aos alunos no fim do bimestre, realizada por meio de práticas avaliativas desconectadas do conteúdo que foi proposto e do modo como foi ensinado.

Nesse sentido, entende-se que a avaliação, dentro da prática pedagógica dos docentes de Educação Física, tem sido feita com descaso, a partir de propostas sem significado para os alunos. Esse panorama, que decorre, muitas vezes, da falta de um planejamento pedagógico fundamentado, me causa inquietação, uma vez que considero a avaliação como parte do processo de construção de conhecimento, e não uma simples verificação de resultado.

A prática da avaliação na Educação Física escolar precisa ser contemplada com a função de orientar o aluno, situando-o frente a seus avanços e dificuldades e incentivando-o superá-las. Ao mesmo tempo, deve servir ao professor como um procedimento que possibilite fazer um balanço dos objetivos (se e quais foram atingidos ou não), da adequação dos conteúdos e da apropriação das estratégias e metodologias de ensino utilizadas.

No esforço de abranger tais necessidades, a utilização do portfólio se apresenta como estratégia atraente, que pode auxiliar a construção de um processo de avaliação mais apropriado à Educação Física escolar. Esse procedimento possibilita ao aluno refletir sobre a construção de seu conhecimento, pois fornece evidências relacionadas a seus avanços e dificuldades de forma contínua e formativa, recolhidas a partir das atividades realizadas ao longo do processo, e não somente ao término do programa de conteúdo.

Sendo assim, o presente estudo procura investigar as possibilidades de utilização do portfólio em aulas de Educação Física escolar, considerando a revisão 
da literatura sobre o assunto, os registros do portfólio feitos pelos alunos no decorrer do projeto e as anotações no diário de campo da professora.

É importante salientar, de início, que o objeto deste trabalho, ou seja, a utilização do portfólio é pouco investigada na Educação. A escolha de um tema tão pouco desenvolvido e sua aplicação à Educação Física escolar justifica-se pelas evidências de que tal prática avaliativa pode oferecer oportunidades de aprendizagem ao aluno, uma vez que, para selecionar suas melhores produções, ele deve reconhecer os objetivos específicos das atividades e os critérios de avaliação, desenvolver suas tarefas, avaliá-las segundo esses critérios e, depois dessas etapas, trabalhar com vistas ao alcance de outros objetivos.

A vivência desse processo desenvolve princípios de grande relevância no contexto escolar, que são citados por VILLAS BOAS (2004; 2006), tais como construção, reflexão, criatividade, parceria, auto-avaliação e autonomia do aluno diante do trabalho. Para os professores e pais essa prática pode representar um excelente meio para conhecer os alunos aprendem e discutir formas de ajudá-los a darem continuidade ao trabalho.

O processo de construção do portfólio pode possibilitar ao aluno aprender a tomar decisões sobre a própria aprendizagem, formulando idéias, fazendo escolhas e cumprindo objetivos. Além disso, torna possível a avaliação do processo de ensino e aprendizagem por parte do professor, pois promove a reflexão sobre possíveis ajustes na programação, na ação didática, nos critérios estabelecidos e na qualificação dos resultados, com o objetivo de adequá-los à evolução do aluno, estabelecendo novas pautas de atuação.

No que diz respeito à Educação Física, também é importante levar em consideração o problema evidenciado na prática pedagógica dos docentes da área, que em geral têm empregado na avaliação critérios que carecem de fundamento, se considerado o projeto pedagógico da escola.

A utilização do portfólio oportuniza a reflexão sobre as trajetórias escolhidas no processo de aprendizagem, possibilita redefinir os objetivos e critérios escolhidos para avaliar, favorece a comunicação entre alunos e professor para a análise dos avanços e dificuldades, e promove o registro das atividades realizadas nas aulas. 
Esse procedimento de avaliação pode contribuir qualitativamente na prática avaliativa dos professores de Educação Física, pois possibilita o estabelecimento de relações por meio da reflexão sobre o que fazem e a explicitação de informações que contrastam as finalidades educativas e as atividades realizadas, além de permitir ao aluno sentir-se responsável por seu processo de aprendizagem.

Com base nesse enfoque, os eixos norteadores deste estudo se organizam em três capítulos, que compreendem: 1) a revisão da literatura a respeito da avaliação; 2) o portfólio como procedimento de avaliação; 3) a exposição dos aspectos metodológicos da pesquisa de campo; 4) análise dos dados da pesquisa.

O primeiro capítulo aborda o conceito de avaliação e seu deslocamento do âmbito dos valores para o da medida objetiva, bem como as conseqüências desse deslocamento na aplicação ao campo educacional.

Em estudos como os de LIMA (1994) e FRANCO (2005) é contemplada a mudança na concepção de avaliação, a partir de 1980, quando se consolidou a tendência progressista libertadora que se contrapunha à postura técnicometodológica da avaliação. Os avanços mais significativos sobre o assunto fortaleceram-se em meados da década de 90 , quando se passou a refletir sobre a necessidade de considerar o processo de ensino e aprendizagem e as variáveis que nele interferem. As propostas de mudança na prática avaliativa dos professores versadas por HADJI (1994) PERRENOUD (1999), VASCONCELOS (2003) e LUCKESI (2005) recomendam que a avaliação aconteça, sobretudo, na efetivação das intenções educativas, e ressaltam que ela deve ser conduzida com enfoque qualitativo, processual e formativo.

Partindo de uma análise histórica, o tema é contemplado, considerando as diferentes concepções de ensino e aprendizagem que fundamentam as abordagens pedagógicas da área. Ainda, é feita a revisão de alguns estudos e periódicos que apresentam como enfoque a discussão da prática avaliativa do professor de Educação Física, dentre os quais se destacam OHLWEILER (1992), SOUZA (1993), ROMBALDI (1996), DARIDO (1999), MAUD (2003), e AROEIRA E RODRIGUES (2006).

Esses estudos evidenciam que a avaliação na Educação Física escolar tem sido caracterizada somente pela função de verificação de aprendizagem e 
dificuldades sem tomada de decisão frente os resultados atingidos e que os professores apresentam um discurso ambíguo no tocante aos domínios teórico e prático da avaliação. Os critérios de avaliação mais utilizados são: a freqüência do aluno e a observação em aula, e a nota é usada como uma ferramenta de poder do professor perante os alunos. Os estudos também confirmam a formação insuficiente do professor de Educação Física para gerar práticas avaliativas mais adequadas.

O segundo capítulo se propõe a contemplar as características do portfólio, procedimento que se fundamenta em princípios que podem melhorar a avaliação da aprendizagem em aulas de Educação Física escolar, considerando a avaliação dos conhecimentos construídos no decorrer das aulas, a sistematização dos conteúdos ensinados, o registro dos conhecimentos adquiridos e a reflexão sobre o próprio processo de aprendizagem.

- No terceiro capítulo, explicita-se o objetivo da pesquisa, justifica-se a escolha da abordagem qualitativa, caracterizam-se os sujeitos que participaram da pesquisa de campo, explicam-se os procedimentos empregados na coleta de dados, bem como os critérios adotados para o tratamento e a organização das informações recolhidas para posterior análise e interpretação. No capítulo seguinte, os dados colhidos na pesquisa de campo serão expostos e analisados à luz da literatura específica e da metodologia adotada e discutida.

Assim estruturado, este trabalho tenciona expor e analisar as possibilidades de emprego do portfólio na Educação Física escolar, por meio de uma intervenção pedagógica. 


\section{REVISÃO DA LITERATURA}

Para desenvolver este estudo, serão abordados, a título de aporte teórico, os vestígios históricos sobre a avaliação da aprendizagem no contexto educacional, a avaliação em Educação Física escolar e o portfólio como procedimento de avaliação da aprendizagem dos alunos.

\subsection{Vestígios históricos sobre a avaliação da aprendizagem no contexto educacional}

Avaliação é um tema complexo, tradicionalmente relacionado à aferição da aprendizagem para apontar o rendimento escolar. A partir de vestígios históricos, buscamos indícios para refletir sobre essa problemática no contexto da educação atual.

Segundo MACHADO (2002), uma confusão de expressões aproxima a palavra avaliação e os termos medida e valor. Na perspectiva do autor, é necessário, por um lado, sedimentar a definição de avaliação como um juízo de valor e, por outro, desmistificar o significado de que só é possível realizá-la por meio de medidas objetivas que destacam apenas os resultados finais. Assim, uma questão bastante fecunda, sobre a qual é necessária uma investigação sistemática, diz respeito à maneira como o conceito de avaliação foi deslocado do campo dos valores para o domínio da medida.

A palavra avaliar tem origem no latim $a+$ valere, que significa atribuir valor e mérito ao objeto em estudo (KRAEMER, 2006, p.1). São muitos os significados da ação de avaliar. No uso comum, lato sensu, alguns dicionários da língua portuguesa ${ }^{1}$ registram para o termo os significados de ajuizar, apreciar, calcular, compreender, computar, considerar, determinar o preço ou merecimento, o valor ou a valia, fazer idéia, fazer apreciação, reconhecer a força, grandeza ou intensidade, prezar, reputar.

As acepções demonstram que a idéia de avaliar inclui tanto a noção de calcular, determinar numericamente ou expressar algo em valor numérico, como a de

\footnotetext{
${ }^{1}$ Os dicionários consultados constam nas referências bibliográficas, no fim deste trabalho.
} 
atribuir valor ou emitir juízos sobre um processo para a aferição da qualidade de seu resultado.

A consolidação da concepção de avaliação como medida teve início nos séculos XVI e XVII, com o surgimento da educação escolar, que tinha como objetivo promover 0 acesso às dimensões da cultura erudita, mais precisamente a leitura e a escrita. Foi nesse período que apareceram as primeiras provas e exames destinados a avaliar o trabalho intelectual dos alunos, aplicados pelas pedagogias jesuítica ${ }^{2}$ e comeniana ${ }^{3}$, que utilizavam a avaliação como instrumento para a manutenção do exercício de poder (LUCKESI, 2005).

GHIRALDELLI JR. (1997) expõe que esse quadro foi se modificando com o desenvolvimento histórico da instituição escolar, que passou a assumir também a função de preparar as novas gerações para a definição de papéis e posições na sociedade, particularmente no mundo do trabalho. A mudança na visão da avaliação da aprendizagem, segundo MACHADO (2002), aconteceu a partir da segunda metade do século XIX, em decorrência do movimento positivista das ciências naturais.

As ciências naturais influenciaram as práticas pedagógicas escolares, instituindo uma lógica de rigorosidade exagerada para a verificação de resultados na aprendizagem. Grande importância era dada ao desempenho em termos de raciocínio, memória e seqüências lógicas de conhecimento, para que o saber adquirido pelos alunos fosse medido com mais facilidade. Assim, a avaliação afastou-se decididamente do caráter de acompanhamento da aprendizagem dos alunos para se efetivar na busca de resultados irrefutáveis, definidos nos termos das concepções científicas vigentes.

\footnotetext{
2 "A pedagogia jesuítica consistia em aulas de ler, escrever e contar números, para os filhos dos colonos e para os índios mais avançados. (...) Havia orações e missas em latim, com a presença obrigatória não só dos alunos, mas também de todos os seus familiares. Pode-se dizer que a Companhia de Jesus foi a instituição responsável pelo único trabalho intelectual realizado durante os séculos XVI e XVII, no Brasil" (MATOS e NUNES, 2006, p.4)

${ }^{3}$ Sobre o modelo educacional comeniano, é importante considerar que Comenius, no século XVII, "avança uma proposta de organização escolar que prevê quatro graus sucessivos, para cada um dos quais delineia objetivos, conteúdos e métodos, com uma meticulosidade e uma minúcia por vezes excessivas, que desemboca na repetitividade e no pedantismo" (MATOS e NUNES, 2006, p.5).
} 
Segundo FRANCO (2005), isso gerou um emaranhado de estudos sistemáticos que divulgavam testes, criação de escalas para medição da inteligência humana e sistemas de atribuição de notas para os comportamentos observados, tendo como referência aqueles considerados ideais sob o ponto de vista das ciências. Também o centro de acuidade se deslocou da tarefa de avaliar para o desenvolvimento de tecnicidades avaliativas interpostas pelo paradigma da medida objetiva.

Os estudos pioneiros que enfocaram as tecnicidades da avaliação da aprendizagem escolar ocorreram por volta de 1920. Segundo ALMEIDA JÚNIOR (2004), desenvolveu-se na França a docimologia, uma ciência que, no ramo da Educação, consiste no estudo sistemático dos exames e atribuição de notas dos comportamentos dos examinadores e dos examinados, cujo principal propagador foi o francês Pieron. Essa ciência disseminou-se para outros países, como Portugal e Estados Unidos, e a partir de 1931 a avaliação agregou ainda outra área de estudos, a psicometria. Essa se constitui num conjunto de operações que, por meio de provas especiais e técnicas científicas, procura determinar e avaliar as capacidades psíquicas dos indivíduos. Foi um método que se direcionou à busca da exatidão e da credibilidade das ciências psicológicas.

A partir de 1930, foram apresentadas pesquisas e propostas sobre a avaliação da aprendizagem, fomentando investigações que se voltaram às análises de currículo e de programas de ensino. Nesse sentido, segundo SOUZA (2005), Tyler propôs a avaliação centrada em objetivos, bastante difundida na prática dos educadores brasileiros, com a intenção de determinar a equivalência entre os resultados e os objetivos estabelecidos no processo de ensino. Esse modelo, mais tarde ampliado por Smith, contribuiu para definição da avaliação da aprendizagem com características que se assemelham aos processos de produção industrial, pois exalta o controle curricular e a aprendizagem de conteúdos, e desconsidera as diferenças entre os alunos.

Nesse período, a avaliação ainda se caracterizava por práticas de verificação quantitativa de conteúdos e comportamentos, mas algumas mudanças já vinham acontecendo. O foco, que antes se centrava apenas no aluno como objeto a ser 
avaliado, passou a considerar, também, a apreciação do currículo e dos programas de ensino.

Outro vestígio de alteração na visão do processo de avaliação é representado pelos estudos pós-Tyler, com o surgimento das primeiras reflexões que entendiam a avaliação como um elemento integrante do processo de ensino e aprendizagem. É o caso, citado por SOUZA (2005) ${ }^{4}$, da proposta de avaliação da aprendizagem cuja sistematização é denominada Taxonomia de Bloom, em referência a seu autor, Benjamin Bloom, que estabeleceu três categorias para a organização dos objetivos educacionais: cognitiva, afetiva e psicomotora. A intenção dessa proposta era classificar os comportamentos do aluno, demarcando as aquisições e os modos de raciocínio para auxiliá-lo a progredir em direção aos objetivos traçados. Também apontava a necessidade de o professor estabelecer uma relação entre esses objetivos e os comportamentos que os alunos deveriam aprender e que seriam avaliados.

$O$ trabalho de Bloom foi amplamente divulgado e tem sido referência em discussões sobre o tema, já que, como aponta ZAINA (2001), foi a partir desses estudos que surgiram as primeiras ponderações sobre a avaliação formativa, ampliadas por Scriven em 1967.

Entretanto, cabe salientar que a concepção de avaliação demarcada nos métodos de estudiosos como Tyler, Smith e Bloom empenhou um esforço demasiado para a criação de métodos e técnicas de medida arquitetados com foco na necessidade de manter o rigor exagerado nos processos avaliativos. Essa tendência contribuiu para se firmar, especificamente na educação brasileira, uma visão totalmente limitada com relação ao ensino e à avaliação da aprendizagem.

É possível entender a forte influência, na educação brasileira, da tendência de avaliação voltada às técnicas de medida objetiva provindas dos autores americanos supracitados, a partir do que explicita David Neto, citado por SAUL (2006): a avaliação da aprendizagem foi, até meados da década de 50, o tema mais estudado

\footnotetext{
${ }^{4}$ SOUZA (2005) traça um panorama dos especialistas que se debruçaram sobre o tema e influenciaram as práticas avaliativas no Brasil. Dentre eles, destacam-se Tyler, Taba, Fleming, Popham, Bloom, Ebel, Gronlund, Ausubel e Ragan.
} 
na área de educação no âmbito internacional. Os diversos sistemas avaliativos desenvolvidos tinham uma visão de controle do currículo e do planejamento como objetivo principal. Para tanto, valiam-se, conforme LIMA (1994), da medida e manipulação dos dados colhidos por meio de procedimentos matemáticos.

David Neto menciona que a preocupação, no âmbito internacional, a partir desse período, começou a voltar-se para as conseqüências que os processos de ensino, aprendizagem e avaliação traziam ao contexto educacional, como, por exemplo, elevados índices de reprovação e baixo nível de qualidade da educação escolar. Foi assim que, na década de 60, surgiram críticas severas à educação caracterizada pela tendência reprodutora ${ }^{5}$ ou "bancária", como a ela se refere Paulo Freire.

Por outro lado, SAUL (2006) mostra que a invasão dessas críticas no pensamento educacional brasileiro só aconteceu com uma distância de quase duas décadas em relação ao cenário internacional, ou seja, a partir do fim da década de 70 , entrando pela de 80 .

Essa defasagem de 20 anos em relação aos Estados Unidos não se deu por acaso. Embora a educação brasileira já recebesse, na década de 30, influências da psicologia, com a propagação de testes e medidas para avaliar a aprendizagem e a inteligência dos alunos, foi nas décadas de 60 e 70, em função dos empréstimos contraídos pelo Brasil aos EUA, que se consolidou na educação brasileira uma forte marca americana. Essa influência revelou-se nas formas de trabalho, nos livros-texto, nas programações, nas ações de alteração curricular e, conseqüentemente, nas formas de avaliação da aprendizagem dos alunos.

Houve grande afluência de técnicos americanos para oferecer treinamento aos professores brasileiros; por outro lado, vários professores brasileiros fizeram mestrado e doutorado nos Estados Unidos, de onde trouxeram uma bibliografia que influenciou os cursos das universidades brasileiras, bem como a prática pedagógica nas escolas públicas.

\footnotetext{
${ }^{5}$ A tendência reprodutora da educação é a compreensão sobre educação e escola como meros instrumentos, aparelhos ideológicos do Estado. Essa perspectiva de educação considera que o aluno é inicialmente vazio e precisa da escola para ser preenchido, seguindo padrões de ensino e aprendizagem pautados em ideais preconizados pelo Estado, como, por exemplo,

formar cidadãos não-críticos, incapazes de refletir e agir com autonomia.
} 
É mediante esses vestígios históricos que se explicam práticas pedagógicas amparadas por proposições de ensino não-críticas, representadas pela reprodução de conhecimentos e valores descontextualizados, que remontam ao século XIX.

Nesse cenário, o jogo desenvolvido no espaço das intenções escolares subentende uma filosofia de avaliação, rotulada por HADJI (1994) como estimativa. Ou seja, o professor avalia o objeto, utilizando-se de métodos que têm orientação quantitativa determinada por escalas de aferição construídas por especialistas. Assume, do mesmo modo, a postura emblemática de um especialista que mede comportamentos para dizer o peso do ser e captar a realidade, pesando-a. Essa visão redundou na concepção de um indivíduo automatizado e sem subjetividade.

A partir do período que circunscreveu a visão funcionalista do ensino e da avaliação, aspirando a uma nova visão pedagógica, que compreendesse um modelo social igualitário, configurou-se na educação brasileira, por volta de fins da década de 1970 e início da década de 1980, a tendência progressista libertadora. Ela é representada pelo pensamento e a prática pedagógica de Paulo Freire, que se preocupou com os modos de superação do autoritarismo, criticando-o e defendendo o estabelecimento da autonomia do educando e a participação democrática de todos.

Assim, surgiram discussões que situavam a avaliação da aprendizagem sob a ótica qualitativa, contrapondo-se à postura técnico-metodológica da matriz objetivista do sistema educacional brasileiro. Segundo LIMA (1994, p.71), o campo qualitativo caracteriza-se por "sua complexidade, tendo em vista o caráter relativo, intencional e valorativo". A avaliação qualitativa tem por base determinar o valor do ser, e não dizer seu peso. O professor, nesse tipo de avaliação, deve ajudar o aluno no processo de aprendizagem, num contexto propriamente personalista.

FRANCO (2005) aprofunda a discussão sobre a avaliação qualitativa, atribuindo-lhe um caráter diferente: como modelo subjetivista. Nessa perspectiva, a avaliação tem como preocupação principal a apreensão cognitiva das habilidades $\mathrm{e}$ competências dos alunos, adquiridas ou em desenvolvimento. A autora ressalta a importância que o modelo subjetivista conferiu à atividade do sujeito. Entretanto, pode-se dizer que esse modelo assumiu um enfoque excessivamente psicologizante como subproduto das investigações a seu respeito. Tal perspectiva se mostrou insuficiente para explicar a realidade educacional, pois as observações geravam 
análises muito abstratas sobre os alunos.

Os apontamentos da corrente qualitativa/subjetivista apresentam avanços nas discussões sobre avaliação, pois defendem a apreciação do processo em que são obtidos os resultados de aprendizagem. Esse posicionamento tem relação com o que expõe HADJI (1994) sobre a filosofia da avaliação nomeada como apreciativa. Segundo o autor, os métodos utilizados para a avaliação apreciativa são orientados pela matriz qualitativa e designam a valoração dos resultados de aprendizagem, qualificando os dados obtidos no processo, julgados à luz do dever-ser.

Sob a mesma perspectiva, PERRENOUD (1999) pontua que é preciso ficar atento a essa visão de avaliação, pois ela assinala juízos de excelência escolar provenientes da construção intelectual, cultural e social do professor que julga 0 aproveitamento do aluno e sua respectiva qualificação segundo suas próprias teorias.

As proposições de mudança na compreensão do ato de avaliar entendido como medida se fortaleceu em meados da década de 90, o que demonstra quanto tais discussões são recentes e quão poucas pesquisas existem de aplicação na prática escolar.

Nesse período, a ideia da avaliação realizada com instrumentos baseados em provas cabais de determinados comportamentos foi ampliada e as discussões passaram a abordar a necessidade de ponderar outros aspectos, como, por exemplo, a decisão conjunta sobre a aprendizagem e a superação das dificuldades encontradas, incentivando a autonomia intelectual, promovendo a comunicação, o diálogo, à transparência das intenções didáticas, e considerando as diferenças individuais dos alunos e as características do contexto.

Segundo HADJI (1994), esse movimento expressou a terceira grande filosofia da avaliação referenciada na teoria crítica da Educação. Ela preconizou a investigação e a construção de um referente capaz de compreender o aluno em sua singularidade. Desse modo, o ato de avaliar passou a ser visto como um processo que não é passível de mensuração, como não o é a aprendizagem que dele decorre.

Essa visão pode ser considerada a mais promissora para gerar no trabalho docente debates pedagógicos que criem elementos de crítica ao modelo de ensino, aprendizagem e avaliação que está posto. Isso porque, entende-se que essa 
concepção pondera as funções sociais da avaliação escolar e suas repercussões no ensino e na aprendizagem. Confere destaque à "voz" do aluno, utilizando seus significados como meios de revisão do papel do avaliador. Minimiza a normalização da escola, optando pela criatividade e autonomia no trabalho pedagógico. Admite a heterogeneidade entre os alunos e a necessidade de interpretação dos resultados de avaliação à luz das características individuais e do contexto em que os alunos estão inseridos.

Entretanto, essa visão de avaliação parece não ter atingido a prática pedagógica dos professores. Percebe-se que o professor, ao modular o processo de ensino e aprendizagem, avalia de modo a favorecer o rompimento do caráter dialético do desenvolvimento do aluno e do trabalho pedagógico.

PERRENOUD (1999) aponta que as discussões inovadoras que contrapõem essa visão de avaliação são recentes e têm gerado, no imaginário dos professores, visões e práticas que não se baseiam em reflexão ou estudo teórico. Isso se evidencia, por exemplo, na ambigüidade das concepções de avaliação, voltadas tanto à dialética formativa como à prática tradicional.

A avaliação centrada na perspectiva formativa associa-se a dispositivos didáticos a serviço da aprendizagem dos alunos, ou seja, a avaliação é concebida como procedimento de coleta de informações, sistematização e interpretação das informações e, por fim, tomada de decisão para promover o desenvolvimento das aprendizagens. Na avaliação tradicional, por sua vez, as técnicas cumprem a finalidade de verificar as aprendizagens adquiridas e selecionar os alunos, para atender a diversos fins: controle da disciplina, passaporte para a próxima série, garantia de habilidades e competências consideradas necessárias para que o aluno possa ser inserido na sociedade, sobretudo, no mundo do trabalho.

Além de observar esse mesmo panorama, ROMÃO (1998) afirma em seu estudo a existência de distintas concepções de avaliação da aprendizagem no interior das escolas brasileiras: de um lado, a defesa da avaliação quantitativa, classificatória ou periódica; de outro, a consideração de pontos de vista mais recentes, como a perspectiva qualitativa, diagnóstica e formativa, que ficam apenas nos discursos. 
PERRENOUD (1999) entende que para o professor se definir e escolher uma lógica de avaliação adequada é necessário, primeiramente, a escola evoluir e abarcar concepções mais amplas e abertas de avaliação, como é proposto nas novas pedagogias, que procuram adotar práticas avaliativas que sejam democráticas, constantes, contínuas e diversificadas, sistemáticas e intencionais.

Dentre as características apontadas, o caráter democrático se destaca por considerar que a avaliação é o lugar de negociação no movimento de definição de objetivos, critérios e procedimentos adotados. E também por ser o território em que os alunos têm oportunidade de aplicar seus conhecimentos e apresentar suas dúvidas, inseguranças, incertezas. Nesse sentido, segundo DEMO (2005), avaliar democraticamente oportuniza aos alunos e professores um espaço de diálogo e participação.

A partir da discussão exposta acima, considera-se nesta dissertação a perspectiva de avaliação lógica formativa, como a explica HADJI (1994, p.7):

A avaliação formativa desejável é um retorno de informação multidirecional, dirigida ao aluno, ao invés de referir-se ao aluno. Tal avaliação não pressupõe nem julgamento de valor, nem escala de valor. Esta é a sua segunda característica: a avaliação formativa inscreve-se no projeto de ajudar os alunos, esclarecendo-os. Trata-se de ajudar o aluno a tomar consciência das dificuldades que encontra, a reconhecer e a corrigir ele próprio seus erros. Ao mesmo tempo, trata-se de esclarecer o professor/avaliador sobre os efeitos reais, em termos de aprendizagem, de sua ação de ensino. É para todos os atores do cenário pedagógico trabalho de aprendizagem do aluno, trabalho de ensino do professor.

Para alcançar essa concepção, considera-se que as intenções educacionais devem fundamentar-se em aspectos mais qualitativos com relação às concepções de ensino, aprendizagem e avaliação, que revelem a essência e totalidade do processo educativo ( PERRENOUD, 1999).

Entretanto, mediante a realidade que se apresenta no contexto educacional, é possível explicar que a dificuldade dos professores em realizar a avaliação da aprendizagem pode estar atrelada à falta de clareza conceitual sobre o assunto. A falta de conhecimento sobre o que é avaliação e qual a sua função no processo de ensino e aprendizagem dificultariam aos professores convencerem-se da necessidade de mudança.

Diante desse panorama, compreende-se que se faz necessário redimensionar a formação dos professores para que possam entender a avaliação como um 
dispositivo didático integrado ao processo de ensino e aprendizagem, coerente com as características do contexto escolar em que os alunos estão inseridos.

Este tópico visou a retratar o panorama da avaliação da aprendizagem no contexto educacional. As explicações históricas trazem indicativos da dificuldade do professor para inserir em sua prática pedagógica a avaliação de maneira processual e formativa.

É necessário investigar os estudos que tratam a avaliação da aprendizagem com foco na Educação Física escolar para compreender o problema proposto à luz da prática pedagógica dos professores da área.

\subsection{Avaliação em Educação Física escolar}

Na literatura nacional sobre Educação Física escolar o debate sobre a prática pedagógica, sobretudo, a avaliação da aprendizagem é ainda escasso. Uma análise de fontes históricas será realizada para delinear a visão sobre as práticas de avaliação desempenhadas pelos professores da área.

Em meados do século XX, as propostas de trabalho do Método Francês e do Método Desportivo Generalizado (MDG) tinham a ginástica como conteúdo e adotavam os princípios eugenistas e higienistas ${ }^{6}$ da época. Essas propostas levaram a um ensino centrado na figura do professor e com pouco significado para os alunos.

O Método Francês apresentava como conteúdo os jogos, exercícios educativos, esportes individuais e coletivos. A metodologia de ensino oferecia o mesmo tratamento a todos os alunos, ou seja, as diferenças individuais não eram consideradas e os estudantes deveriam executar as propostas de aula sem questionar. O processo de avaliação métodos pautava-se em testes padronizados com tabelas que apresentavam dados anátomo-fisiológicos como critérios para a obtenção de resultados de medidas biométricas (SOUZA, 1993; DARIDO, 1999).

\footnotetext{
${ }^{6}$ Os princípios higienista e eugenista se caracterizavam, respectivamente, pela preocupação com a saúde pública e o melhoramento genético da raça humana. Segundo esses princípios, o trabalho físico era considerado o oposto do intelectual.
} 
O Método Desportivo Generalizado, de acordo com BETTI (1991), originouse da proposta de August Listello, na década de 40. O método tinha como conteúdo o esporte e o jogo; a metodologia de ensino se baseava em uma seqüência padronizada de aula. O processo de avaliação considerava o desempenho motor, que era testado e medido, utilizando-se como parâmetro tabelas construídas por especialistas.

É possível observar que as duas perspectivas expostas ainda freqüentam a concepção e a prática de muitos professores de Educação Física. No entanto, elas podem ser entendidas como limitadas para serem seguidas no atual contexto sócio, político e educacional em que vivemos, uma vez que seguem um modelo de avaliação que se concretiza por meio de normas, tabelas e padrões aplicados de forma descontextualizada, homogeneizando a observação do comportamento dos alunos.

Nas décadas de 60 e 70, o esporte ganhou força no contexto escolar, passando a ser encarado pelas elites governamentais como promoto da nação frente ao mundo. O conteúdo das aulas era técnico-desportivo. A metodologia de ensino seguia o modelo piramidal, em que os níveis mais altos dependem de níveis mais baixos. Os instrumentos de avaliação consistiam em testes de competência técnica e física que valorizavam os mais hábeis e excluíam os que não obtinham sucesso nas práticas.

SANTOS (2006) realizou um estudo, no contexto da Educação Física escolar, sobre os principais referenciais teóricos a respeito da avaliação veiculada nos periódicos de 1930 a 2000. Identificou como referencial teórico na produção de 1960 a 1970 os estudos de Pophan e Tyler, com a proposta da avaliação por objetivos. Tal proposta se manifestou em autores como SINGER e DICK (1980). Eles reconheciam a necessidade de considerar a individualidade dos alunos, porém defendiam 0 processo quantitativo de avaliação, baseado nos objetivos de ensino. O professor de Educação Física evidenciava os comportamentos que estavam se modificando nos alunos, utilizando instrumentos de testagem referenciados pelos domínios da aprendizagem cognitiva, afetiva, psicomotora e social. Esse referencial teórico ratificava avanços na concepção de ensino e aprendizagem, no que diz respeito à formulação de objetivos didático-pedagógicos, fundamentando-se em diferentes 
domínios (cognitivo, afetivo, psicomotor e social). No entanto, ainda se limitava à idéia de avaliar comportamentos fáceis de observar e passíveis de ser mensurados com instrumentos de verificação.

Ao se comparar o Método Esportivo com os resultados do estudo de SANTOS (2006), encontram-se contradições. Os periódicos especializados estimavam a necessidade de estabelecer objetivos com base nos diferentes domínios do conhecimento, mas o Método Esportivo dava ênfase, exclusivamente, ao aspecto da competência técnica motora. Isso demonstra que os avanços da avaliação na Educação Física escolar ficaram mais no campo teórico do que no prático.

Observa-se, até esse momento, que a avaliação seguiu o caminho percorrido pelas demais áreas da Educação, priorizando os testes com padrões de aprendizagem preestabelecidos e tabelas de quantificação para evitar a subjetividade na comparação dos resultados.

Foi a partir de 1980, com influência das ciências humanas, que se passou a questionar a ênfase às padronizações de desempenho que sustentava a perspectiva de avaliação do Método Esportivo. Nesse contexto, o estudo do corpo humano e sua ação motora recebeu contribuições da psicologia, sociologia e história.

LE BOULCH (1986) e VAYER (1977) destacaram-se com sua proposta de educação psicomotora, fundamental para a Educação Física escolar repensar as concepções vigentes. A educação psicomotora caracterizava-se por considerar que o bom desenvolvimento motor poderia auxiliar as capacidades cognitivas, como o aprendizado da escrita e da leitura. O processo de avaliação utilizava a observação do movimento, com foco nos processos cognitivo e socioafetivo necessários à execução do ato motor.

Houve, assim, um grande interesse pelo desenvolvimento motor por parte dos professores de Educação Física. Dentre as correntes teóricas surgidas com base nesse prisma destaca-se a abordagem desenvolvimentista, que trouxe elementos das teorias do desenvolvimento humano e das subáreas de aprendizagem motora e desenvolvimento motor.

Essa abordagem é marcada pela obra de TANI, MANOEL, KOKUBUN e 
PROENÇA (1988), que se apóia no princípio da análise do desenvolvimento infantil, considerando a maturação, as características individuais e as experiências adquiridas. Observa-se que a avaliação não é uma temática discutida especificamente nessa publicação, mas os parâmetros da proposta de conteúdo, que caracteriza a progressão normal do crescimento físico e do desenvolvimento mediante observação sistemática do comportamento motor, podem assessorar a avaliação da prática pedagógica do professor no sentido de verificar a adequação dos conteúdos ao longo das faixas etárias.

Outra fonte histórica que marca mudanças conceituais na área é a publicação de FREIRE (1989), em que o autor toma como referencial teórico os campos da psicologia, da aprendizagem e do desenvolvimento cognitivo. Embora ele próprio não se defina como tal, é considerado percussor das idéias construtivistas na área.

Em sua proposta assinala uma compreensão não-punitiva da avaliação, associada ao processo pedagógico. Pondera, além do aspecto motor, a importância de levar em consideração as relações interpessoais e o crescimento do aluno. Enfatiza o uso de procedimentos como a auto-avaliação e a construção de sociogramas para observar o desenvolvimento do grupo, num processo que permite ao aluno participar da própria avaliação.

É perceptível que no fim da década de 80 os debates em torno da renovação da Educação Física escolar no Brasil ampliaram o quadro de referenciais teóricos, assimilando mais os aportes oriundos das ciências sociais e humanas.

$\mathrm{Na}$ década de 90 destaca-se a perspectiva teórica crítico-superadora, que recebeu influência específica da filosofia, história e sociologia ${ }^{7}$. É considerada a abordagem mais relevante para a construção de um conceito de avaliação na área por ser a única que apresenta uma proposta sistematizada de avaliação. Os apontamentos iniciais são totalmente avessos às práticas de avaliação que excluem os alunos. Os autores apresentam aspectos relevantes, nos quais, o professor pode acompanhar os avanços e as dificuldades no processo de ensino e aprendizagem, a

\footnotetext{
${ }^{7}$ A obra Metodologia do ensino de educação física organizada por SOARES, C.L.; TAFFAREL, C.N.Z.; VARJAL, E.; CASTELLANI FILHO, L.; ESCOBAR, M.O.; BRACHT, V. é uma das principais publicações nessa linha teórica.
} 
saber: a diversidade das condutas humanas; práticas avaliativas diferenciadas; decisões compartilhadas nos âmbitos de professor-aluno e aluno-aluno; fornecimento do tempo necessário ao aluno; compreensão crítica da realidade vivida; intencionalidade da avaliação vinculada à proposta de conteúdos e estratégias adotadas pelo professor; a nota como síntese qualitativa do processo de ensino e aprendizagem.

Outra proposta pedagógica, surgida na década de 90, que tem relevância para a Educação Física escolar, é a chamada abordagem sistêmica. BETTI (1994), o principal autor dessa vertente, define sua perspectiva a partir do modelo sociocultural. Defende que o processo de ensino e aprendizagem deve estar vinculado ao projeto político-pedagógico da escola. No entanto, essa tendência pedagógica não apresenta uma prescrição de avaliação.

Sendo assim, a contribuição dessa abordagem para a construção de um conceito sobre avaliação na Educação Física escolar reside nos princípios de nãoexclusão e diversidade. Quanto ao primeiro, entende-se que é preciso garantir práticas de ensino e avaliação que acompanhem o processo de aprendizagem dos alunos e não os selecionem como mais ou menos capazes. Com relação ao segundo princípio, compreende-se que a avaliação não deve focalizar apenas o conteúdo esportivo e a execução do movimento; deve abarcar a diversidade presente na cultura corporal do movimento.

Outro ponto relevante nessa abordagem é o fato de defender a conexão do programa de Educação Física com o projeto político-pedagógico da escola. Embora o autor não explicite as implicações dessa conexão com a avaliação, pressupõe-se que o componente curricular de Educação Física deve dialogar com os aspectos avaliativos das demais disciplinas escolares. Pensar dessa forma possibilita a integração dos objetivos do professor de Educação Física com os dos demais professores da escola.

Finalmente, os Parâmetros Curriculares Nacionais (BRASIL, 1997) constituem-se em um documento importante para a área, pois trazem orientações para os currículos escolares, incluindo a Educação Física. A partir desse documento, baseado no trabalho de COLL e seus colaboradores e na experiência da reforma curricular espanhola, a fundamentação teórica básica para a 
noção de conteúdo da Educação Física escolar foi ampliada e a aprendizagem passou a ser considerada em função de três dimensões: procedimental, conceitual e atitudinal. Os conteúdos são organizados em três blocos com temas da cultura corporal de movimento que se articulam entre si e guardam suas especificidades: a) conhecimentos sobre o corpo; b) atividades rítmicas e expressivas; c) esportes, jogos, lutas e ginásticas (BRASIL, 1997).

$O$ documento sugere que os aspectos avaliados devem ter relação direta com os objetivos e conteúdos, respeitando-se as diferenças individuais em suas motivações e possibilidades. Para isso, preconiza que na avaliação o professor não deve esperar o mesmo resultado de todos os alunos. Para cada ciclo de escolaridade são indicados diferentes critérios de avaliação, a fim de melhorar a organização do programa de ensino, procedendo a uma seqüência de práticas coerentes com os conhecimentos que se pretende ensinar.

Nesse sentido, as metáforas de HADJI (1994) sobre o professor avaliador assentam como corolário do panorama histórico da avaliação realizada pelo professor de Educação Física no Brasil:

a) Metáfora do especialista: as fontes históricas, de 1900 até o fim da década de 1970, revelam que, em razão da situação social e política, suas escolhas pedagógicas, especialmente no que diz respeito à prática avaliativa, a postura do professor de Educação Física coincide com a do especialista ou técnico, que utiliza a medição de comportamentos observáveis e mensuráveis para certificar a aprendizagem por meio de critérios normativos. Destaca-se o Método Francês e MDG, em que se destaca a avaliação realizada por meio de testes de competência física e técnica.

b) Metáfora do juiz: na década compreendida entre 1980 e 1990, com as abordagens psicomotora e desenvolvimentista, o professor assume a figura de um investigador que avalia os alunos, orientando-se por critérios preestabelecidos como "ideais" a serem atingidos no processo de ensino e aprendizagem;

c) Metáfora do filósofo: a partir de 1990, como se constata nas perspectivas teóricas: construtivista, crítico-superadora e sistêmica, assim como nos 
PCNs, a postura do professor com relação à avaliação dos alunos baseiase na compreensão da realidade, considerando as particularidades do contexto histórico, social e cultural em que os alunos estão inseridos. $O$ foco da avaliação se volta para os resultados recolhidos no processo de ensino e aprendizagem e para a promoção da formação humana do aluno.

O exame a seguir, de estudos sobre como o professor avalia a aprendizagem dos alunos na atualidade, permitirá avançar na compreensão do assunto.

\subsection{Pesquisas recentes sobre a avaliação na Educação Física escolar}

DARIDO (1999) expõe as principais linhas de pensamento em relação à avaliação em Educação Física, construídas no período compreendido entre a década de 1970 e o fim da década de 1990. Baseando-se em informações sobre a prática de avaliação dos professores de Educação Física a partir de diferentes pesquisas, aponta as mudanças ocorridas no processo de avaliação da aprendizagem dos alunos.

Uma análise dos dados observados pela autora the permitiu constatar que a prática pedagógica dos professores de Educação Física caracterizava-se por uma perspectiva tradicional quanto à avaliação, já que valorizavam ações que testavam, quantificavam e priorizavam, exclusivamente, o produto da aprendizagem. Em contrapartida, os professores consideravam a avaliação voltada à forma processual e qualitativa, ao mencionarem a necessidade de a avaliação promover a participação dos alunos, valendo-se de procedimentos como a auto-avaliação. Para a autora, esse fenômeno evidenciou a ambigüidade no discurso dos professores, por apontar duas concepções distintas de avaliação.

Sobre a atribuição de nota os professores se fundamentavam em critérios que incluíam a observação da participação e do interesse do aluno. Isso a autora interpreta como um indicativo de mudança em relação ao período até meados da década de 80 , quando a atribuição de nota era centrada apenas no desempenho físico-motor. Por outro lado, a autora se deparou com a falta de apontamentos suficientes sobre o que é feito com os resultados coletados no processo de 
avaliação, de onde pôde inferir que a avaliação era realizada como um fim em si mesmo.

Essa pesquisa contribui com este estudo na medida em que revela a ambigüidade conceitual e prática do professor de Educação Física, que demonstra falta de conhecimentos consistentes a respeito de como encaminhar a avaliação em suas aulas. Mesmo apontando a consciência de uma perspectiva de avaliação adequada e condizente com as propostas inovadoras no contexto educacional, sua prática se restringe à medição e verificação de resultados.

Quanto à mudança observada pela autora, quanto à escolha dos critérios de avaliação, que passaram a incluir a participação e observação dos alunos para a atribuição de nota, entende-se que, ainda assim, essa visão precisa ser ampliada. Isso porque a avaliação tradicional não dá conta da complexidade de um programa de ensino de Educação Física que abarque vários tipos de conteúdos, e desse modo não contempla as dimensões do conhecimento que realmente foi ensinado e aprendido em aula.

Percebe-se, por essa pesquisa, que não houve mudanças representativas na concepção de avaliação do professor de Educação Física entre a década de 70 e a atualidade. Essa constatação torna evidente a necessidade de incentivar nos professores a reflexão sobre a avaliação, não como uma prática isolada, mas como um dispositivo didático que também tem importância no processo de ensino e aprendizagem.

Um estudo de OHLWEILER (1992) procurou analisar a avaliação da aprendizagem na prática pedagógica de 31 professores de Educação Física em 11 escolas públicas e duas da rede privada, no antigo primeiro grau (do terceiro ao sexto ano do Ensino Fundamental), na cidade de Santa Cruz do Sul (RS). Os resultados apontaram que a avaliação realizada pelos professores de Educação Física não ultrapassava a verificação da aprendizagem, uma vez que eles se preocupavam em registrar e constatar os resultados, sem tomar providências frente aos dados coletados. A avaliação apresentou-se reduzida apenas ao fazer/executar, privilegiando a competência técnica e reforçando a seletividade e a marginalização dos alunos. 
Na discussão dos resultados, a autora assinala a necessidade de aprofundar a formação dos professores para que a avaliação seja entendida pelo viés crítico, contextualizado, deixando de lado a visão de que a avaliação é um "elemento terminal do processo de aquisição do conhecimento" (OHLWEILER, 1992, p.154). Ao contrário, o professor deve priorizar a lógica da avaliação direcionada ao acompanhamento do aluno.

Observam-se em OHLWEILER (1992) resultados semelhantes aos expostos na pesquisa de DARIDO (1999). Entretanto, a discussão apresentada na primeira aponta indicadores que podem direcionar mudanças na avaliação realizada pelos professores de Educação Física, como, por exemplo, a avaliação entendida como ação de acompanhamento do aluno. Essa noção considera que a aprendizagem se manifesta de formas diferentes e que a avaliação deve ser realizada de maneira individual, em vários momentos do processo de ensino e aprendizagem. Além disso, considera que a avaliação não deve limitar-se ao aluno, podendo se estender ao acompanhamento da prática de ensino do professor.

SOUZA (1993) investigou 36 professores de Educação Física, atuantes no Ensino Fundamental de quinta a oitava série da rede pública, na cidade de Nova Iguaçu (RJ). Constatou que 72,2\% dos docentes tinham em vista a avaliação clássica (ou tradicional); 2,8\% situavam-se em uma perspectiva humanista-reformista; e 25\% não manifestaram uma definição consistente sobre a prática da avaliação. Com relação aos indicadores de avaliação do processo ensino e aprendizagem, a habilidade desportiva foi o objeto de avaliação mais apontado. Ao investigar os critérios de avaliação utilizados pelos docentes, foi detectado que eles não tinham claro o critério de avaliação, uma vez que não faziam distinção entre critérios, procedimentos e objetos de avaliação. Além disso, foi apontado por $91,8 \%$ dos docentes que o poder de decisão no processo de ensino e aprendizagem é atributo exclusivo do professor de Educação Física, pois deixaram transparecer em suas falas que esse processo referenciava apenas sua opinião, sem base em fundamentação ou reflexão sobre o tema.

Sobre a função da avaliação, 44,4\% dos sujeitos demonstraram uma compreensão caracterizada pela fragmentação, já que entendiam tal prática de forma isolada do processo de ensino e aprendizagem. Demonstravam praticar modalidades 
de avaliação (auto-avaliação, provas, testes, observações) sem questionar sua função, o momento mais adequado para lançar mão de cada modalidade, a finalidade de propor uma modalidade ou outra. Esse dado revela a falta de compreensão, por parte dos professores, sobre como, por que e para que avaliar.

A respeito das técnicas e procedimentos de avaliação, as provas práticas (testes físicos) e provas foram detectadas como os métodos mais empregados, o que levou a autora a constatar uma tendência para a avaliação tradicional. A tendência crítico-social não foi evidenciada nos planos pedagógicos dos professores. Os procedimentos de avaliação utilizados pelos professores não guardavam analogia/identidade com as perspectivas humanista-reformista e crítico-social de avaliação.

Por fim, a pesquisa apontou que as elaborações reflexivas sobre avaliação parecem não fazer derivar uma prática avaliativa no contexto escolar. A falta de subsídios teóricos expressada pelos professores para explicar e caracterizar as próprias práticas assinala a urgência de mais estudos que possam gerar novas elaborações reflexivas, além de práticas que subsidiem a formação do docente de Educação Física, capacitando-o para avaliar a aprendizagem dos alunos e reformular a própria atuação pedagógica.

Essa pesquisa aponta para resultados semelhantes aos encontrados por OHLWEILER (1992) e DARIDO (1999) e evidencia que a avaliação da aprendizagem nas aulas de Educação Física é realizada de maneira isolada das atividades de ensino.

Segundo PERRENOUD (1999), essa forma de proceder à avaliação cria rupturas entre o tempo de ensinar/aprender e o tempo de avaliar, o que ratifica uma lógica de atividades avaliativas fechadas, que prioriza a verificação de conhecimentos avulsos e descontextualizados da forma de ensino e aprendizagem.

ROMBALDI (1996) observou um panorama parecido no contexto universitário. Em seu estudo sobre os posicionamentos e as opiniões dos professores das disciplinas técnico-desportivas de instituições de Ensino Superior do Rio Grande do Sul, com relação à avaliação no Ensino Fundamental e Médio e na formação profissional, constatou que eles encontravam dificuldades quanto a esse assunto. Os docentes apontaram o curso de formação profissional como responsável por ensinar 
os futuros professores a avaliarem. Outra conclusão desse estudo foi que a avaliação é vista como um processo contínuo que verifica o alcance dos objetivos, necessita respeitar os limites dos alunos e possibilitar a tomada de decisão, que deve ser de competência tanto do professor quanto do aluno. Os critérios de avaliação mencionados pelos sujeitos pesquisados foram o interesse, a participação, as atitudes, o envolvimento do aluno, o senso crítico e a execução de movimentos; os procedimentos de avaliação apontados como os mais utilizados foram o trabalho em grupo e a prova.

A pesquisadora constatou a prioridade conferida à atribuição da nota no final de um programa de conteúdo, o que foi ressaltado na fala dos sujeitos. Também constatou que os docentes apresentaram em seus discursos desvinculação entre 0 que preconizavam em seus discursos e o que realmente era feito (na prática). Evidenciou-se, na ótica da autora, a falta de conhecimento dos professores formadores sobre a prática de avaliação.

Nos resultados explicitados por ROMBALDI (1996) entende-se que a forma como os professores de Educação Física avaliam corresponde aos modelos que vivenciaram em seu processo de formação, o que se confirma no discurso dos professores universitários formadores de professores de Educação Física. Esses docentes explicitam princípios apropriados para conduzir uma avaliação no processo de ensino e aprendizagem, mas quando questionados sobre como transportam tais princípios para a prática eles revelam que sua avaliação se reduz à verificação do que foi aprendido, para atribuição de nota. Ou seja, a avaliação é realizada com um fim em si mesma.

A avaliação em Educação Física escolar é discutida por MAUD (2003) com base no relato de sua experiência pedagógica. A autora reflete sobre a avaliação na escola e analisa as principais obras da área. Em seu estudo, realizou um trabalho de campo como professora-pesquisadora, com crianças do quarto ano do Ensino Fundamental, norteando-se pela tendência crítico-superadora. A autora concluiu que a avaliação sem caráter punitivo aumentou a participação dos alunos e foi relevante na atuação docente, pois possibilitou identificar a inter-relação entre o processo de ensino e aprendizagem e a avaliação em uso na prática pedagógica. Também apontou que a avaliação apoiada em teoria bem estudada e definida enriqueceu sua 
prática pedagógica, mostrando que a avaliação pode ser muito mais do que o mero cumprimento de uma norma burocrática.

Considera-se original o estudo de MAUD (2003) por tratar-se de um tipo de pesquisa que pode ser caracterizada como aplicada, abordando a prática da avaliação em aulas de Educação Física. $O$ processo de formação docente apresentado pela autora a partir da prática de avaliação demonstra que é possível integrar ensino, aprendizagem e avaliação nas aulas de Educação Física e propiciar aos alunos aprendizagens mais eficientes.

Outro estudo descritivo, apresentado por AROEIRA e RODRIGUES (2006), analisa o discurso de professores de Educação Física no Ensino Fundamental, em cinco unidades escolares da rede municipal de Vila Velha (ES). O foco dessa investigação é a necessidade de situar, na produção educacional, o modo como o professor de Educação Física está avaliando. Os resultados apontam avanços e problemas na prática pedagógica de avaliação na área.

Quanto aos avanços, no discurso da maioria dos entrevistados há apontamentos que se aproximam da visão de avaliação identificada nas produções de estudiosos como Hoffman, Luckesi, Romão e Vasconcelos. Esses autores têm contribuído para a discussão do tema na educação brasileira, tendo como foco a perspectiva qualitativa e formativa.

A respeito das características do processo avaliativo, a pesquisa revelou a necessidade de privilegiar a avaliação contínua; entretanto, os professores afirmam que a prática mais comum é a avaliação acumulativa e pontual. Os autores também constataram que os procedimentos de avaliação mais mencionados pelos professores foram as provas reflexivas, práticas e a observação em aula, sem que os docentes soubessem explicar e justificar a escolha desses métodos, o que evidencia sua falta de conhecimento sobre a prática de avaliação.

Com base nos resultados de pesquisas recentes, apresentados até aqui, é possível perceber que não houve mudanças substanciais na compreensão da avaliação como parte do processo de ensino e aprendizagem. O discurso dos professores, nos estudos apresentados, expressa desde compreensões que evidenciam avanços acerca do papel da avaliação da aprendizagem até distorções sobre o caráter da avaliação e equívocos quanto aos objetivos dos procedimentos. 
Essas observações possibilitam destacar alguns eixos de discussão, que serão abordados a seguir:

- avaliação como verificação da aprendizagem;

- ambigüidade no discurso dos professores;

- mudanças na escolha do objeto de avaliação;

- a nota como instrumento de poder;

- necessidade de formação dos professores.

\subsubsection{Avaliação como verificação da aprendizagem}

Esse indício é apontado nos estudos de OHLWEILER (1992), SOUZA (1993), DARIDO (1999), AROEIRA e RODRIGUES (2006). Observa-se que a verificação da aprendizagem é uma prática avaliativa que estabelece relação com os métodos de avaliação empírica e verificacional utilizados na produção industrial e adaptados para o contexto educacional no modelo proposto por Tyler. Segundo SANTOS (2006), esse é um referencial teórico presente nos periódicos compreendidos entre 1960 e 1970 como uma forma de pensar a avaliação da aprendizagem dos alunos na Educação Física escolar.

Sob influência de pensar a avaliação desse modo, os professores da atualidade seguem, muitas vezes, paradigmas inconscientes que compõem um saber-fazer ou saberes que (in)formam suas ações de maneira acrítica e irrefletida. A idéia de avaliar apenas para verificar a aprendizagem restringe a avaliação a um julgamento dos alunos feito pelo professor, de forma individual. Desse modo, ele não pondera nenhum outro aspecto do processo de ensino e aprendizagem durante a avaliação e, muito menos, usa os resultados observados para avaliar e redirecionar as práticas de ensino e aprendizagem utilizadas.

LIMA (1994) considera que o professor, nessa perspectiva, acaba assumindo a postura de detentor do saber, com poder de julgar o que os alunos aprenderam, seguindo um paradigma de verdade particular. Assim, a avaliação se torna uma prática exercida como instrumento de poder do professor, que desconsidera a possibilidade de os alunos terem voz nesse processo e não serem os únicos a ser 
avaliados: o professor e aspectos do contexto escolar também deveriam fazer parte do processo avaliativo.

\subsubsection{Ambigüidade no discurso dos professores}

Essa discussão está presente nos estudos de ROMBALDI (1996), DARIDO (1999) e AROEIRA e RODRIGUES (2006). Os autores apontam uma ambigüidade no discurso dos professores de Educação Física, que consiste na manifestação de aspectos qualitativos da avaliação, como as observações processuais e formativas, tendo como contraponto aspectos quantitativos, com a priorização de procedimentos que quantificam os resultados de aprendizagem dos alunos.

A desvinculação entre o que é dito e o que realmente é feito nas aulas de Educação Física, no que diz respeito à avaliação, expõe o fato de que os professores não conseguem estabelecer analogia entre a teoria e a prática. Infere-se que as discussões sobre a avaliação no processo de ensino e aprendizagem na Educação Física estão situadas no plano acadêmico e não alcançam os professores inseridos nas escolas.

A conseqüência disso é a compreensão limitada do professor sobre questões ligadas à avaliação, tais como: conhecer seus aspectos técnicos, saber utilizá-los e discuti-los, assim como os critérios avaliativos, os objetivos da avaliação, o diagnóstico dos problemas encontrados pelos alunos e a utilização coerente de procedimentos avaliativos. Esse quadro implica estagnação dos saberes pedagógico e deficiência da ação de educar a serviço da aprendizagem dos alunos e da melhora dos procedimentos de ensino e avaliação.

De qualquer modo, o que se observa é que mudar as práticas avaliativas não é fácil. Convivemos por décadas com uma avaliação repressiva e excludente, que está arraigada, permeando as práticas vigentes. Mesmo assim, entende-se que a mudança das práticas meramente verificativas para práticas mais eficientes só será possível se o professor for formado adequadamente, estabelecendo coerência entre o discurso e a prática pedagógica, de modo a incorporar práticas avaliativas voltadas ao acompanhamento dos alunos e de seu processo de ensino. 


\subsubsection{Mudanças na escolha do objeto avaliado}

No que diz respeito ao objeto a ser avaliado, observa-se que as publicações de uma década atrás, como as de OHLWEILER (1992) e SOUZA (1993), detectaram que os professores de Educação Física privilegiavam a competência técnica e as habilidades esportivas ao avaliarem seus alunos. Já publicações recentes, como as de DARIDO (1999) e MAUD (2003) abalizam os objetos de avaliação, abarcando as dimensões atitudinal e procedimental e indicando princípios qualitativos para fundamentarem a observação da aprendizagem do aluno.

A mudança no foco de observação do professor durante o processo de avaliação decorreu da ampliação do quadro teórico, instaurada no final dos anos $80 \mathrm{e}$ durante a década de 90 , com a instituição de novas propostas pedagógicas para a área, cujo ponto de debate voltou-se para a superação do paradigma da aptidão física.

No entanto, de acordo com DARIDO (1999), as práticas de avaliação se restringem a critérios como a freqüência e a observação em aula. Ou seja, a avaliação situa-se, sobretudo, na dimensão do saber-fazer e das atitudes em aula. Desse modo, são desconsiderados indicadores situados além dos parâmetros motores e afetivo-sociais, bem como a dimensão conceitual. Partindo da definição de OLIVEIRA (1991), que afirma o papel da Educação Física no ensino e aprendizagem de fatos, conceitos, princípios, procedimentos, normas, valores e atitudes referentes ao movimento humano, entende-se que se a avaliação da aprendizagem tendo como foco apenas a observação de procedimentos e atitudes, acentua-se a predominância de alguns conhecimentos em detrimento de outros, o que contribui para a falta de equilíbrio nas dimensões de conhecimentos no processo de ensino, aprendizagem e avaliação.

FERRAZ (2004) defende que para o aluno ser avaliado de forma apropriada, de acordo com as diferentes dimensões do conhecimento, é necessário o professor definir o que e como avaliar, vistas essas duas instâncias como elementos interdependentes. Ao mesmo tempo, deve-se levar em conta que a avaliação precisa estabelecer relação com o tipo de conteúdo e aprendizagem desenvolvidos nas atividades de ensino. 
Mesmo admitindo propostas educacionais inovadoras, como, por exemplo, considerar a avaliação de indicadores de aprendizagem além dos aspectos motores, percebe-se limitações do professor para investir num ensino mais coerente com essas propostas e numa avaliação mais eficiente para os alunos.

\subsubsection{A nota como instrumento de poder}

Em DARIDO (1999) e nos estudos de SOUZA (1993) e ROMBALDI (1996) torna-se evidente que a nota é atributo exclusivo do professor. É a expressão de seu poder, cabendo a ele definir as dificuldades e facilidades do aluno por meio da atribuição de nota ou conceito, um recurso simplificado que identifica a posição do aluno em uma escala.

VASCONCELOS (2003) e LUCKESI (2005) expõem que, no contexto escolar, é dada mais importância à nota do que ao processo de aprendizagem. Isso contribui para o desvirtuamento da avaliação, na medida em que assegura um sistema classificatório que reproduz as relações da sociedade de classes, incentivando valores de competição.

Nesse sentido, é distorcido o real papel da avaliação no processo de ensino e aprendizagem - acompanhar e mudar a situação de aprendizagem identificada , uma vez que a nota passa a ser usada como instrumento de discriminação, formalmente legitimado por um símbolo, que pode ser um número ou letra.

SOARES, C.L.; TAFFAREL, C.N.Z.; VARJAL, E.; CASTELLANI FILHO, L.; ESCOBAR, M.O.; BRACHT, V. (1992) defendem a necessidade de mudança no significado da atribuição de nota aos alunos nas aulas de Educação Física. Os autores expõem que é preciso redimensionar o sentido burocrático da nota e procurar meios de demonstrar a síntese do processo de aprendizagem do aluno. Ou seja, consideram que a nota não deve ter a função de punir o aluno; deve informar sobre os caminhos percorridos no processo de ensino e aprendizagem e permitir a reconstrução de metas a serem perseguidas.

Para isso ocorrer, entende-se ser necessária uma formação de professores que os capacite a ampliarem sua compreensão sobre o significado da nota no processo educacional, desmistificando a idéia de que o que importa é o resultado, ou 
seja, a nota. O professor deve vivenciar práticas diferentes dessa realidade, como a avaliação contínua, diária, que não valoriza o produto final, mas todo o processo. Deve compreender o erro como parte do processo de aprendizagem, permitindo ao aluno errar para aprender. Além disso, a avaliação deve ser vista como o diagnóstico que aponta os problemas relacionados ao processo de ensino e aprendizagem e favorece a tomada de decisões para encontrar soluções no contexto de ensino.

\subsubsection{Necessidade de formação dos professores}

A maioria dos estudos apresentados apontou que os professores de Educação Física carecem de formação mais consistente no que diz respeito à avaliação do processo de aprendizagem.

Em ROMBALDI (1996) e DARIDO (1999) as declarações dos professores evidenciam a insuficiência de seu conhecimento sobre o papel da avaliação no processo de ensino e aprendizagem. Por conseguinte, eles desconhecem formas eficientes de conduzi-la em suas aulas.

A explicação para tal problemática, segundo TANI (1996, p.15), remete às questões que envolvem a formação dos professores de Educação Física para atuarem no ensino básico, durante muito tempo representada pelo

caráter muito genérico das disciplinas de orientação pedagógica, a falta de integração destas com as disciplinas orientadas às atividades, a simples reprodução de técnicas de movimentos nas disciplinas orientadas às atividades e superficialidade dos conhecimentos teóricos desenvolvidos.

Com base no que diz o autor, observa-se que a estrutura frágil dos cursos de licenciatura em Educação Física não tem conseguido desenvolver uma formação competente para o professor atuar no contexto escolar. As lacunas presentes no processo de formação, como a fragmentação dos conhecimentos básicos produzidos de forma espiralada, a ausência de correspondência entre eles e sua desvinculação da realidade escolar, contribuíram, e ainda contribuem, para a falta de aprofundamento teórico e científico da prática pedagógica de maneira geral.

Desse modo, a improvisação e a ausência de compromisso com a avaliação são demonstrados nas aulas de Educação Física. O descomprometimento com a transformação dessa realidade existe porque os professores desconhecem outro 
modo de fazer e acabam reproduzindo o ensino e a avaliação que tiveram em seu processo de formação.

A reprodução de práticas de ensino e avaliação colabora, como foi observado nos itens anteriores, para a construção de paradigmas inconscientes que sedimentam a lógica da transmissão de conhecimentos e da verificação da aprendizagem. Diante desse quadro, justifica-se a necessidade de maior reflexão em torno da prática educativa do professor de Educação Física. MAUD (2003) e OHLWEILER (1992) consideram que um nível mais profundo de reflexão só será atingido quando os professores da área forem sensibilizados e estimulados a se atualizarem com relação à avaliação. Para isso são necessárias mais discussões e problematizações acerca de sua prática pedagógica, envolvendo questões relacionadas não somente à avaliação, mas também às concepções de ensino e aprendizagem. Não há como separar o ensino, a aprendizagem e a avaliação no processo de formação, pois essas instâncias estão relacionadas entre si e a serviço de um mesmo objetivo: a promoção de uma educação coerente para a melhora do ensino e da aprendizagem dos alunos.

Nesse sentido, considera-se necessário definir um paradigma para uma Educação Física escolar menos determinista e linear, tanto do ponto de vista dos conhecimentos que são validados pelas instituições responsáveis pela formação de professores quanto do ponto de vista das iniciativas de formação continuada.

É importante que a transição de paradigma situe a discussão em torno das concepções de ensino, aprendizagem e avaliação, estimulando no professor seu envolvimento crítico para que possa repensar autonomamente sua postura pedagógica e reelaborar seu fazer profissional, em especial a ação avaliativa gerada por uma perspectiva crítico-reflexivo (SILVA, 2007).

A perspectiva da redefinição das práticas escolares por meio da prática críticoreflexiva é auxiliar o desenvolvimento de métodos que ajudem a dar voz e visibilidade ao que é silenciado e apagado com relação às aprendizagens expressas pelo aluno no decorrer do processo de ensino, uma vez que as práticas de avaliação realizadas pelos professores em suas aulas inviabilizam essa possibilidade. 
Encontram-se nas abordagens atuais sobre ensino, aprendizagem e avaliação subsídios teóricos, tais como o desenvolvimento da autonomia, da participação e da cooperação entre os indivíduos envolvidos no processo, que podem auxiliar tais mudanças na Educação Física escolar. Um exemplo é a proposta do portfólio, que preconiza o processo de avaliação no decorrer das aulas, promovendo situações de reflexão, a integração das atividades de ensino, aprendizagem e avaliação. Com essas características, considera-se que esse procedimento pode trazer contribuições para a Educação Física escolar, não só no âmbito da avaliação da aprendizagem, mas também na intervenção pedagógica dos professores de maneira geral. As possibilidades do portfólio como procedimento para uma avaliação mais eficiente será abordado no próximo capítulo.

\section{O PORTFÓLIO COMO UMA POSSIBILIDADE DE INTERVENÇÃO PEDAGÓGICA EM EDUCAÇÃO FíSICA}

As discussões sobre a avaliação da aprendizagem assinalam que o professor deve se aprofundar nos subsídios teóricos que fundamentam sua prática pedagógica.

$\mathrm{Na}$ Educação Física escolar, observou-se em vários estudos que uma redefinição das práticas de avaliação da aprendizagem apresenta-se como necessária. Para essa mudança, é imperativa a existência de embasamento teóricoreflexivo que ajude os professores a compreenderem a função da avaliação no processo de ensino e aprendizagem e a adotarem uma metodologia que evidencie e favoreça a aprendizagem dos alunos no processo educativo.

Nesse sentido, a proposta do portfólio apresenta possibilidades para a Educação Física escolar. É um procedimento de avaliação que pode impulsionar mudanças na ação de ensinar e avaliar do professor, já que a concepção do porttólio pressupõe um processo dinâmico que rejeita a fragmentação entre os atos de aprender e avaliar. 


\subsection{0 que é portfólio?}

MARTIN-KNIEP (2001) e VILLAS BOAS (2004) definem o portfólio como um procedimento de avaliação que se constitui de acordo com as finalidades e espaços em que é aplicado, podendo ser empregado na escola, em empresas ou individualmente, para fins pessoais. Freqüentemente, encontram-se diversas designações para esse procedimento: porta-fólio, portfólio, diário de aprendizagem, dossiê e registro pessoal. Nota-se, porém, que tais termos apresentam diferentes especificidades que delimitam o que vem a ser o portfólio no contexto escolar:

- Porta-fólio: conjunto ou coleção de material publicitário (sugestões de provas etc.) que se leva ao cliente para aprovação. Com esse sentido é, geralmente, usado em alguns ofícios, como o dos estilistas, cineastas, fotógrafos, arquitetos, marqueteiros e designers. Os porta-fólios são compostos com o propósito de demonstrar 0 melhor de sua produção para a entrada no mercado de trabalho (VILLAS BOAS, 2004).

- Portfólio: segundo vários autores ${ }^{8}$, é uma pasta em que os artistas e os fotógrafos iniciantes reúnem uma amostra do que melhor evidencia o caminho que percorreram até chegar ao estado final da obra para apresentá-la a especialistas ou professores. CAMARGO (1997) complementa que os artistas se sentem, atraídos pela construção de portfólios para organizar e apresentar suas obras devido ao potencial do procedimento para expressar o que não é possível dizer apenas com palavras. (CAMARGO, 1997, p.176) O portfólio utilizado como procedimento de avaliação da aprendizagem no contexto escolar deriva da idéia apregoada no campo da arte, mas com particularidades explicitadas por GARDNER (1994). O portfólio no campo educacional tem conotação diferente porque é entendido como a organização de trabalhos com a finalidade de reunir indícios de aprendizagem e das dificuldades enfrentadas no processo de ensino e aprendizagem dos alunos.

- Diário de bordo, ou diário de aprendizagem: são termos empregados por SHORES e GRACE (2001) para se referirem a uma forma de registro que pode ser inserida no portfólio. Os autores o distinguem como um registro resumido de tudo o que

${ }^{8}$ VILLAS BOAS (2004), GARDNER (1994), HERNÁNDEZ (1998) e VALLE (2002). 
comunica a forma individual do processo de aprendizagem do aluno, em que devem ser preservadas suas idéias, suas descobertas ou o relato de fatos importantes.

- Registro pessoal: SHORES e GRACE (2001) e VILLAS BOAS (2004) consideram que essa forma de registro pode ser inserida no portfólio, mas não pode ser considerada portfólio, por tratar-se de registros que não são norteados por um critério específico, com a intenção principal de conhecer a opinião pessoal do aluno durante uma experiência de aula ou algum evento fora da escola.

- Dossiê: a palavra vem do francês dossier e designa, segundo NOGUEROL (1999), o local onde se guardam registros produzidos pelo aluno ou professor, como anotações sobre a aula, mantendo uma ordem cronológica. Entende-se que o portfólio não deve ser confundido com o dossiê, porque tem objetivos mais amplos do que esse. $O$ foco do portfólio é a reflexão e expressão da aprendizagem do aluno, por meio de um diálogo com fontes, conceitos e evidências que devem ser organizados e analisados na perspectiva dos alunos e do professor.

-Webfólio: é um termo recente que designa a avaliação da aprendizagem por meios eletrônicos. Segundo HERNÁNDEZ (1998; 2000), pode ser disponibilizado na Internet, em cursos de educação presencial ou virtual. O autor aponta o blog, espécie de diário muito utilizado na Internet, como uma forma de introduzir a prática do portfólio de aprendizagem com os alunos. Esclarece que, embora um blog não seja um webfólio, ele pode ser organizado dessa forma porque sua estrutura permite registrar tanto 0 processo quanto 0 produto das aprendizagens que ocorrem na escola. $O$ autor apresenta-o como uma alternativa para avaliar no Ensino Médio ou Superior. Ressalta que tal opção leva em conta o que atrai a atenção dos alunos e, assim, pode motivá-los a produzir registros, possibilitando aprendizagens mais eficientes.

Mediante as designações apresentadas, optou-se neste estudo por adotar a palavra portfólio, por ser mais conhecida no contexto escolar, muito embora em muitos relatos os estudiosos focados no mesmo contexto (escolar), também façam referência à palavra porta-fólio com o mesmo sentido. 
O conceito aqui considerado fundamenta-se em VILLAS BOAS (2004), que o distingue como um procedimento de avaliação privilegiado para o desenvolvimento de processos que envolvem a seleção, comparação, auto- avaliação, parceria e o estabelecimento de objetivos, mais do que de produtos, o que constitui um de seus pontos fortes. É permitido no portfólio todo tipo de registro para manifestação da aprendizagem e das dificuldades: a escrita (descritiva, analítica, poética etc.), o desenho ou a pintura, a fotografia, realizados em grupo ou individualmente.

O portfólio permite ao aluno representar a sistematização do conhecimento de forma cumulativa e dinâmica, além de atender aos desejos e às necessidades de complementação de cada aluno. De um lado, a qualidade de ser um procedimento cumulativo pressupõe a necessidade de o professor acompanhar o aluno em seus avanços; de outro, o fato de ser dinâmico permite (e impõe) retomadas, idas e vindas sobre o que o aluno já sabe e aquilo que ainda não é conhecido. Esse é o ponto mais especial do portfólio, que favorece a formação de sujeitos autônomos e conscientes de seus processos de aprendizagem, já que possibilita ao aluno reconhecer e controlar a própria aprendizagem.

A origem desse procedimento de avaliação, segundo HERNÁNDEZ (2006), está situada na década de 80, a partir das contestações a respeito do modo técnicometodológico da matriz objetivista da avaliação de aprendizagem escolar, com indagações sobre o modo como ela era praticada. $O$ autor expõe como um dos focos do debate a ausência de relação entre a prática avaliativa e as novas propostas pedagógicas decorrentes de abordagens voltadas para o estabelecimento da autonomia e da participação democrática dos alunos, representadas pelo pensamento e a prática pedagógica de Paulo Freire.

A falta de afinidade entre os conceitos de ensino, aprendizagem e avaliação configuravam uma educação construtivista que avaliava de forma condutista. Desse modo, buscaram-se meios para ajustar a avaliação da aprendizagem às novas propostas pedagógicas, e vários procedimentos de avaliação foram propostos sob a ótica qualitativa. $O$ autor considera que o portfólio é uma derivação das proposições que apareceram a partir de 1980, fundamentadas, sobretudo, nas prescrições da avaliação formativa. 
O portfólio abrange características derivadas dos princípios da avaliação formativa, sendo processual e dinâmico, trabalhando com múltiplas relações de saberes e proporcionando elementos para o exercício da auto-avaliação e interação entre professor e aluno. Contudo, tem outras singularidades. Ele possibilita uma construção particular por parte do sujeito da aprendizagem, que produz registros de experiências individuais, enfocando a reflexão sobre o que foi ou não aprendido e 0 que pode fazer para melhorar. A organização e a seleção desses registros no portfólio são determinadas pelo aluno, com a mediação do professor. Nesse sentido, compreende-se que o portfólio, além de abranger características da avaliação formativa, proporciona aos alunos participação ativa, atuando como co-responsáveis no processo de ensino, aprendizagem e avaliação.

É importante esclarecer que o portfólio representa uma avaliação que não se restringe a um episódio ou fato isolado, mas integrante de um processo mais amplo, que envolve o ensino e a aprendizagem escolar.

\subsection{Como o portfólio deve ser utilizado?}

Alguns autores ${ }^{9}$ sugerem que a prática de inserção de registros no portfólio seja realizada como atividade diária dos alunos. Consideram que é necessário escolher o registro e o procedimento que será usado para avaliar a aprendizagem dos conteúdos propostos. Uma vez que os conteúdos têm características distintas, os procedimentos de avaliação (matrizes de desempenho, auto-avaliação, registro individuais, avaliação dos colegas, avaliação coletiva, análises de apresentações, testes, provas etc.) devem estar conectados com o tipo de conteúdo e os objetivos que se pretende atingir no projeto.

Portanto, o portfólio não representa o abandono de provas ou da observação em aula, como ocorre, freqüentemente, na Educação Física escolar. Não se deve rejeitar nenhum procedimento de avaliação, já que tanto a prova quanto a observação podem ser importantes para avaliar a aprendizagem. Contudo, tais procedimentos devem ser associados a outros para garantir a avaliação dos

${ }^{9}$ SHORES E GRACE (2001), VALLE (2002), VILLAS BOAS (2004), HERNÁNDEZ (1998; 2000). 
conhecimentos em suas diferentes dimensões em diferentes momentos do processo de ensino e aprendizagem.

VASCONCELOS (2003, p.104) complementa essa discussão, apontando que fazer a avaliação em várias situações é uma forma de superar a concentração em determinados momentos. $\mathrm{O}$ autor enfatiza, porém, que "a finalidade principal desse tipo de prática não é arrumar mais formas de 'gerar nota' para o aluno, e sim acompanhar efetivamente $o$ processo de conhecimento e fazer retomadas necessárias".

Compreende-se que, com a utilização de registros e procedimentos de avaliação variados, o aluno é avaliado com foco no processo de construção do conhecimento, para abranger uma multiplicidade de indícios de aprendizagem. Essa compreensão possibilita o reconhecimento das diferentes qualidades e competências dos alunos.

Um dos procedimentos de avaliação que podem ser inseridos no portfólio, a matriz de desempenho - que também pode ser chamada de matriz de critério, tabela de desempenho e checklist - é apontada pela maioria dos estudiosos do tema ${ }^{10}$ como uma ferramenta interessante, porque tem a intenção de mostrar ao aluno como melhorar seu aprendizado e ajudar o professor na apresentação dos objetivos e critérios de avaliação que queira atingir com determinado conteúdo.

A matriz é utilizada para descrever vários níveis de qualidade de determinado conteúdo, do ótimo ao regular. O objetivo é propor aos alunos um feedback sobre seus avanços e suas dificuldades, e dar suporte para melhorar seu desempenho.

A lista de critérios e a graduação de qualidade são dois pontos relevantes nas matrizes de desempenho. A graduação de qualidade descreve os problemas encontrados na aprendizagem dos alunos, de forma que possam reconhecer eventuais fragilidades e perceber que caminhos podem seguir para melhorar em suas dificuldades.

A construção dos critérios e dos níveis de qualidade do conteúdo, com a participação dos alunos, torna-se importante para garantir que os aspectos a serem

\footnotetext{
${ }^{10}$ NASCIMENTO (2006), ANDRADE (2002), MARTIN-KNIEP (2001), MELOGRANO (1996).
} 
avaliados sejam significativos. A avaliação por meio desse procedimento pode ser realizada pelo professor, pelo próprio aluno ou por algum colega.

A partir da discussão exposta, considera-se que a matriz no contexto da Educação Física escolar pode ser um procedimento significativo para sistematizar os critérios, retomar os objetivos e avaliar o nível de desempenho dos alunos. Entretanto, ela precisa ser construída observando alguns cuidados. É importante lembrar que a área tem uma história marcada, especificamente nos períodos higienista, militarista e esportivista, pela exacerbada utilização de tabelas de desempenho em testes físicos, antropométricos e de habilidades técnicas, que eram aplicados pelos professores, somente, para a verificação, medição e seleção dos melhores e piores alunos nas aulas.

Portanto, a idéia que circunscreve a matriz de desempenho deve estar bem fundamentada para os professores da área, a fim de que esse procedimento não seja confundido com as tabelas de verificação de desempenho. Isso significa que o emprego da matriz deve estar desvinculado da proposta de estabelecimento de padrões ideais de habilidades motoras para o ensino e avaliação de movimentos corporais a serem atingidos por todos os alunos de forma homogênea.

Para que a matriz de critério possa ser inserida nas aulas de Educação Física de maneira proveitosa e apropriada como um método de avaliação é necessário que abarque a idéia de observação, análise e conceituação de elementos da cultura motora, resultando num constante processo de ação-reflexão-ação sobre o que cada aluno alcançou e daquilo que ainda falta alcançar. Deve ser construída coletivamente, levando em conta não só a opinião do professor, mas também a dos alunos.

\subsection{Aspectos da construção do portfólio}

Em relação à construção do portfólio, NASCIMENTO (2006) enumera quatro elementos que considera essencial: conteúdo, organização do tempo, estrutura e envolvimento do aluno.

O conteúdo do portfólio depende de seu propósito e da série a que se aplica. Deve comunicar o que e como os conhecimentos foram compreendidos na 
perspectiva do aluno, com o auxílio do professor, por meio da coleção dos registros de atividades realizadas durante as aulas. Isso pode ser exemplificado no projeto de trabalho com alunos do quarto ano do Ensino Fundamental, tendo por base o tema jogo.

Os conhecimentos expressos no portfólio devem corresponder ao que foi trabalhado nas aulas, por exemplo, a identificação do objetivo, das regras, das habilidades motoras, das estratégias ofensivas e defensivas básicas, do que foi combinado em relação às atitudes na execução dos jogos. Tais conteúdos podem ser registrados por escrito, em gravações das práticas de jogos, gravações das reflexões dos alunos em áudio ou vídeo, em desenhos das estratégias desenvolvidas nos jogos, comentários do professor e registros de avaliação coletiva, que poderão fazer parte do conteúdo do portfólio do aluno.

Um outro pré-requisito para o trabalho com portfólio ${ }^{11}$, especialmente no que diz respeito ao registro dos conteúdos, é a sistematização dos objetivos e dos critérios de avaliação. Esses procedimentos auxiliam os alunos e o professor na manutenção do foco sobre o que está sendo ensinado e o que será avaliado, e norteiam o recorte de conhecimentos essenciais que precisam ser registrados e sobre os quais se procederá à reflexão, evitando que os conhecimentos expressos se dispersem em uma multiplicidade de perspectivas. Sua formulação deve estar relacionada com as intenções e os objetivos do projeto ou programa de ensino, e os registros podem ser construídos de maneira coletiva (entre professor e alunos), sistematizados por meio de itens ou perguntas que devem ficar expostos para os alunos consultarem quando desejarem e acompanhando qualquer tipo de registro ou procedimento de avaliação proposto aos alunos.

Compreende-se que sem uma sistematização desse tipo torna-se difícil avaliar, dado o grande número de informações trazidas pelos alunos, correndo-se o risco de recair num relativismo em que tudo passa a valer, o que poderia diluir a validade da prática do portfólio.

A organização do tempo deve permitir aos alunos o direito de cometer erros, escolher alternativas (frustradas ou não), solucionar problemas, observar avanços,

\footnotetext{
11 Apontado nos estudos de VILLAS BOAS (2004), VALLE (2002), MARTIN-KNIEP (2001) e MELOGRANO (1996).
} 
dificuldades e mudar de direção. Para isso, é necessário disponibilizar aos alunos tempo suficiente para eles realizarem seus registros e assim o professor ter condições de observar e analisar a aprendizagem em questão (NASCIMENTO, 2006).

$\mathrm{Na}$ Educação Física escolar consideram-se relevantes os aspectos mencionados, para que a produção dos registros ocorra simultaneamente à aprendizagem de conteúdos. Isso pode ocorrer, por exemplo, gravando-se o desempenho motor por um colega, seguido de discussão em dupla sobre determinada diretriz para análise e registro de observação da tarefa executada. Ainda, o tempo pode ser organizado para que a vivência aconteça durante a aula e no final seja retomado o que o aluno aprendeu, discutindo-se coletivamente os aspectos em que sentiu dificuldade e o que fazer para melhorar. A produção do registro pode ser proposta como tarefa de casa.

A organização do portfólio deve ter um caráter demonstrativo, que facilite a interpretação e análise do processo de aprendizagem para o aluno e os possíveis leitores que desejem tomar contato com o trabalho desenvolvido (SHORES e GRACE, 2001; NASCIMENTO, 2006).

É importante que o portfólio a ser apresentado a outros leitores tenha um formato adequado, para que seja entendido como um documento de registro das reflexões sobre o processo de ensino e aprendizagem na perspectiva do aluno e do professor. Ele deve representar o processo vivido, e não apenas uma coletânea de trabalhos realizados num determinado tempo.

Portanto, é fundamental que o conteúdo e a forma de organização do portfólio estabeleçam uma coerência interna e ressaltem o processo de reflexão dos alunos e do professor sobre o que foi ensinado e aprendido num determinado programa ou projeto de trabalho.

Na Educação Física escolar, compreende-se que a organização do portfólio e sua apresentação para as pessoas da comunidade escolar (pais, coordenadores, direção pedagógica) pode ser uma valiosa oportunidade para fazê-las reconhecer a relevância do que é ensinado nas aulas e quanto a área contribui para a formação educacional dos alunos.

Por intermédio de NASCIMENTO (2006), entende-se que a leitura do portfólio 
por outras pessoas da comunidade escolar (coordenador, diretor, professores, pais) acaba tornando-o um método de avaliação do processo de aprendizagem do aluno e da proposta de ensino do professor. A avaliação feita por outras pessoas pode ser registrada e utilizada pelo professor como um feedback sobre seu trabalho, favorecendo a realização de ajustes na prática pedagógica. Outra vantagem é a possibilidade de fazer com que os responsáveis ou outras pessoas da comunidade escolar participem do processo de desenvolvimento do aluno, podendo dar seu parecer, e não apenas tomando ciência da situação em que se encontra o aluno apenas no fim de um bimestre ou semestre.

Diante das conjeturas expostas para a organização do portfólio, NASCIMENTO (2006, p.117) sugere alguns itens para compor sua estrutura:

(a) a inclusão de uma introdução que mostre ao leitor o que encontrará no material; (b) uma descrição breve das tarefas; (c) a marcação, com etiquetas, que distinguem as soluções iniciais do relatório final; (d) a datação de todas as atividades que forem acrescentadas ao portfólio; (e) uma sessão de revisão que inclua reflexões dos alunos, auto-avaliação, comentários do professor e dos colegas.

Com base em VALLE (2002), a organização o portfólio deve iniciar-se com uma explicação da finalidade da prática. Considera-se conveniente expor as expectativas de cada aluno e sugere-se que cada atividade incluída no portfólio traga um cabeçalho contendo o tema e a data da aula. A inclusão dos registros no portfólio pode ocorrer em diversas situações do programa ou projeto desenvolvido. Os elementos coletados devem demonstrar as características individuais dos alunos. A escolha do que será inserido pode ser feita tanto pelo aluno quanto pelo professor. É recomendado que o aluno justifique o que escolheu para inserir em seu portfólio e 0 professor anexe um comentário sobre os registros, tendo como foco o processo de aprendizagem revelado.

Entende-se que esse comentário pode ser uma espécie de feedback do professor, fundamentado no objetivo e nos critérios de avaliação combinados previamente em aula. É um momento em que o professor dá sua opinião sobre o trabalho desenvolvido pelo aluno, ressaltando os avanços, pontuando as fragilidades e expondo o que será feito durante as aulas para ajudar os alunos a melhorarem as dificuldades encontradas.

No contexto da Educação Física, KINCHIN (2001) apresenta outra sugestão 
de organização das amostras de trabalho do aluno no portfólio, que divide em três componentes:

- A utilização de diferentes técnicas de avaliação, como observação e tomada de notas logo após uma prática motora, construção e aplicação de matrizes de desempenho individualmente ou em pares, realização de registros diários, registros de observações da professora, relatórios de alunos etc.;

- Reconhecimento da aprendizagem e das dificuldades, auto-avaliação, reflexões individuais, temas pesquisados, escritos, filmados, gravados e listagem de itens sobre o que fazer para melhorar;

- Aplicação de pré-testes, questionários e pós-testes.

A organização sugerida por KINCHIN (2001) para o portfólio dos alunos demonstra que essa proposta de avaliação na Educação Física escolar segue os mesmos princípios expostos pelos autores do campo da Educação, que ponderam a importância de utilizar um conjunto de avaliações e registros para sinalizar o caminho do aluno em seu processo de aprendizagem.

O envolvimento dos alunos ocorre por meio da criação de oportunidades para que participem de seu próprio processo de avaliação. O primeiro passo é envolver os alunos na seleção das amostras de seu trabalho. O segundo é permitir ao aluno participar do processo de avaliação. Nesse momento é interessante promover discussões sobre quais foram os objetivos alcançados, quais as dificuldades encontradas e o que deve ser feito para melhorar. O terceiro passo é o momento em que os alunos podem se expressar sobre seu aprendizado, suas realizações. Assim, selecionando e criticando seu trabalho, o aluno pode rever sua aprendizagem e definir novas metas (NASCIMENTO, 2006).

Os passos expostos ressaltam que o aluno é o principal autor do portfólio. Essa intenção constitui um dos pontos fortes desse procedimento de avaliação. $O$ aluno é envolvido o tempo todo em seu processo de avaliação, diagnosticando os resultados alcançados e decidindo o que pode fazer para melhorar. Portanto, no entender de RANGEL (2003, p. 152), cada portfólio é único e de responsabilidade do aluno,

mesmo que, em momentos demarcados, professor e aluno, os colegas entre si, conversem sobre as produções ocorridas, confirmando a idéia de que a avaliação demanda a interação, a 
troca e a negociação entre os sujeitos envolvidos com determinado objeto.

Porém, é importante ressaltar que não se descarta a mediação do professor na elaboração do portfólio, pois cabe a ele explicitar e retomar, durante todo 0 trabalho, os objetivos, os critérios de avaliação do conhecimento e as diretrizes que auxiliam os alunos na construção do portfólio (MARTIN-KNIEP, 2001; VILLAS-BOAS, 2004).

No contexto da Educação Física escolar, entende-se que a participação dos alunos no processo de avaliação com o portfólio pode se realizar de acordo como os passos citados e elegendo determinados momentos no projeto. Esses momentos são designados, no estudo de RANGEL (2003), como "paradas", que podem ocorrer no meio e no fim de um programa, para organizar os artefatos do portfólio. Também pode ser um momento de troca entre colegas e entre professor e aluno para formalizar o que foi aprendido ou não e o que fazer dali em diante. Percebe-se que, com essa estratégia, o ato de avaliar pode ser aproveitado como um momento de reflexão em que os alunos pensam no que realizaram e em como se sentem, e não como um momento frustrante em que apenas se apontam efeitos desqualificadores do processo de aprendizagem.

Em termos gerais, os elementos apresentados para compor o portfólio norteiam os alunos a respeito dos objetivos do processo de ensino e aprendizagem e organizam os artefatos que facilitam sua compreensão sobre esse processo. É um procedimento de avaliação que deve promover a reflexão constante, auxiliando o aluno a localizar os avanços ou problemas que favoreceram ou dificultaram a aprendizagem.

Percebeu-se, também, que os pressupostos apontados para a implementação do portfólio ressaltam seu caráter multidimensional, que favorece a aquisição de novas aprendizagens e a avaliação delas. Compreende-se que a qualidade de favorecer novas aprendizagens pode ser explicada pela necessidade de os alunos desenvolverem determinadas competências ${ }^{12}$ que pressupõem 0 trabalho com

\footnotetext{
${ }^{12}$ No dicionário Aurélio, "competência" significa a qualidade de quem é capaz de apreciar e resolver certo assunto, fazer determinada coisa; capacidade, habilidade, aptidão, idoneidade. Segundo MACEDO (2005), o ensino de competências na escola é necessário porque envolve a concepção de que a sociedade precisa ser compreendida como um sistema complexo e aberto. Essa consideração é
} 
portfólios. São exemplos disso a retomada dos conhecimentos abordados, a identificação do que foi aprendido ou não, a consideração dos comentários dos colegas e do professor e a elaboração de sínteses dos resultados alcançados.

A qualidade de avaliar a aprendizagem é incentivada pelo processo de reflexão e registro do aluno sobre o que fez, constatando os resultados e tomando decisões sobre o que fazer para melhorá-los.

As competências e habilidades aprendidas no trabalho com portfólio ocorrem de forma simultânea nesse procedimento de avaliação. Elas promovem o envolvimento dos alunos com seu processo de aprendizagem e favorece 0 estabelecimento de significados que facilitam a transferência dos conhecimentos a outros contextos e a adaptação a novas situações (VILLAS BOAS, 2004).

\subsection{A atuação do professor no trabalho com o portfólio}

Segundo VILLAS BOAS (2004), para que tais intenções sejam concretizadas, o professor necessita abandonar o papel de examinador, e o aluno, o de examinado, uma vez que um dos princípios dessa forma de conceber a avaliação é a promoção de parcerias (professor-aluno e aluno-aluno).

KIRK (1997) compartilha dessa opinião, pontuando que o portfólio é um tipo de trabalho que favorece o abandono de atitudes controladoras por parte do professor de Educação Física. Sua atuação deve estar direcionada à mediação da atividade dos alunos, a fim de lhes permitir assumirem a responsabilidade pelas tarefas de aprender e avaliar a aprendizagem. Nesse sentido, os termos parceria e responsabilidade, citados pelos autores, são características intrínsecas ao trabalho

exemplificada, apontando o poder da tecnologia, que nos obriga a conviver com saberes relativos, parciais e fragmentos de conhecimentos, o que nos leva à necessidade de aprender habilidades e competências que nos auxiliem a construir nossas próprias verdades (relativas). Nesse sentido, o autor defende que, na atualidade, a educação para todos deve seguir princípios educacionais que se fundamentem em pedagogias diferenciadas, aprendizagem de conteúdos, avaliação formativa, promoção contínua, desenvolvimento de competências e habilidades relevantes para viver na realidade social e cultural em que estamos inseridos. Partindo desse pressuposto, entende-se que o portfólio favorece a aprendizagem de competências e habilidades específicas que são importantes para viver no mundo moderno, como, por exemplo, saber identificar, sintetizar e organizar informações reveladas no processo de aprendizagem. 
com portfólio, que permitem aos alunos compartilhar os objetivos e critérios de avaliação, tomando consciência de seus próprios processos de aprendizagem.

Alguns estudos ${ }^{13}$ apontam que o portfólio, além da função de avaliar e gerar aprendizagens, pode ser aproveitado como eixo organizador do trabalho pedagógico do professor. Isso porque os indícios de aprendizagem revelados no portfólio dos alunos favorecem a revisão do processo de ensino e aprendizagem e a percepção do que é necessário mudar ou ajustar no trabalho pedagógico.

Esse ajustamento do trabalho pedagógico ocorre quando o professor busca reorganizar as práticas de ensino para manter a coerência entre estas e os objetivos de ensino e aprendizagem a serem alcançados. Isso ocorre por meio de um processo constante de reflexão, que o trabalho com portfólio proporciona ao contrastar as finalidades educativas $e$ as atividades realizadas para sua consecução $^{14}$. Esse processo favorece a contínua reformulação da prática pedagógica e possibilita avanços significativos no processo de aprendizagem dos alunos.

Ao que tudo indica, para a efetivação do trabalho com portfólio, é necessário que o professor reveja tanto sua concepção de aprendizagem quanto suas práticas de ensino, pois esse procedimento exige um novo olhar do professor sobre a forma de ensinar, a fim de modificar a maneira de avaliar os alunos.

Nesse sentido, a concepção de ensino e aprendizagem que tende a contribuir para a efetivação do trabalho com portfólio é a construtivista, que preconiza, segundo COLL e MARTíN (1998), o aprender a aprender, aprender a pensar, a refletir e a criar. Nessa concepção o aluno não é considerado desprovido de conhecimento, e sim alguém capaz de raciocinar e apreender sentidos por si mesmo e em interação com os outros. O conhecimento é entendido como uma construção humana de significados na interpretação do mundo. Ele deve ser abordado nas dimensões factual, conceitual, procedimental e atitudinal, para que haja aprofundamento, compreensão dos conhecimentos existentes, descoberta e criação de novos conhecimentos, os quais devem ser significativos para os alunos. Além disso, supõe-

\footnotetext{
${ }^{13}$ VILLAS BOAS (2004), MARTIN-KNIEP (2001), HERNÁNDEZ (1998, 2000).

${ }^{14}$ VILLAS BOAS (2004) e HERNÁNDEZ $(1998,2000)$.
} 
se, nessa concepção, que o aluno é capaz de refletir, ou seja, de pensar e fazer inferências sobre seu processo de aprendizagem.

O enfoque teórico do construtivismo se atém mais à interpretação e ao entendimento do processo de aprendizagem do que à obtenção de conhecimentos ensinados e avaliados na perspectiva da repetição e memorização (POZO, 1998). Observa-se, portanto, que a concepção de ensino e aprendizagem construtivista pode fundamentar o trabalho com portfólio, não só favorecendo a avaliação da aprendizagem, mas também auxiliando na transformação da prática pedagógica dos professores. Já que os processos de ensino e de avaliação são compreendidos como funcionando de forma conectada, o que é considerado é todo o caminho percorrido pelos alunos, e não só o produto da aprendizagem. Assim, o conhecimento prévio é contemplado e são respeitadas a individualidade e as diferentes habilidades dos alunos para aprender e expressar a aprendizagem. As práticas de ensino e avaliação sugeridas pela perspectiva construtivista incentivam a interação entre os alunos e entre professor e aluno, além da participação ativa dos aprendizes, refletindo sobre o processo em que tomam parte.

$\mathrm{Na}$ prática pedagógica do professor de Educação Física, as intenções educacionais apontadas para o trabalho com portfólio podem possibilitar mudanças no processo de ensino, aprendizagem e avaliação. Esse é um aspecto importante, tendo em vista a falta de afinidade, sublinhada por alguns autores ${ }^{15}$, entre o modo de pensar o ensino, a aprendizagem e a avaliação na área de Educação Física escolar. Ou seja, ensina-se de uma forma e se avalia de outra. Agindo assim, o professor de Educação Física assume uma postura de descaso com relação ao ato de avaliar (RODRIGUES, 2003).

Para produzir uma mudança na prática pedagógica de Educação Física escolar com o uso do portfólio é essencial uma fundamentação consistente, que articule, de forma construtiva, a prática de ensino exercida em aula e a avaliação, sob pena de tomar o portfólio como mais um método a ser aplicado de modo imediatista, fragmentado e destituído de significado no processo educativo dos alunos.

${ }^{15}$ OHLWEILER (1992), SOUZA (1993), DARIDO (1999). 
A principal contribuição do portfólio é o fato de valorizar e estimular nos alunos a reflexão sobre seu processo de aprendizagem em contexto. Ele capacita os alunos e o professor a perceberem os avanços e as dificuldades, e incita a busca de caminhos que ajudem a superar os problemas encontrados. O processo de reflexão possibilita aos alunos desenvolverem o senso de apropriação do trabalho, pois permite que façam escolhas, tomem decisões e selecionem os registros que representam o progresso de sua aprendizagem. Assim, trata-se de um procedimento que modifica a visão de aluno passivo, mero reprodutor dos conhecimentos oferecidos pelo professor, pois a essência da proposta do portfólio é fazer com que o aluno se torne agente do próprio aprendizado, com procedimentos e responsabilidades definidas, que precisam ser contempladas.

O portfólio também organiza e sistematiza o conhecimento trabalhado, estimula a criatividade, desconstrói a idéia de formalização das matrizes de atividades fornecidas aos alunos, permite a livre expressão, evoca a necessidade de promover parcerias, oportuniza à comunidade escolar tomar conhecimento sobre 0 que os alunos aprendem e ao professor conhecer (melhor) seus alunos e seu trabalho pedagógico, reajustando-o no decorrer do processo de ensino e aprendizagem.

É um procedimento que requer do professor algumas competências e habilidades, como a observação sistemática, com registros sobre a aprendizagem dos alunos, o oferecimento de comentários encorajadores, a valorização das diferentes iniciativas individuais e o exercício da paciência, uma vez que esse procedimento exige um tempo maior para a apreensão do que os alunos estão aprendendo ou não.

Outros requisitos referentes à prática de ensino são necessários para o trabalho com o portfólio. Por exemplo, o professor possibilitar aos alunos a vivência de propostas desafiadoras, que estimulem a pesquisa e a aplicação do conhecimento em situações reais. Também a escolha dos procedimentos de avaliação e a prática dos registros diários pelos alunos devem estar adequadas aos conteúdos ensinados e ter objetivos e critérios de avaliação explicitados.

Dentre as vantagens da aplicação do portfólio nas aulas de Educação Física, destaca-se, além do que já foi mencionado acima, o fato de que ele pode possibilitar 
um olhar ampliado sobre os conteúdos propostos, pois os registros (escritos, desenhados, fotografados ou filmados) podem se tornar, de acordo com SOARES (2001), "signos" que ficam gravados na memória de forma sistematizada para os alunos.

A forma como se deve utilizar o portfólio também é relevante, haja vista a possibilidade de superar a idéia de avaliação realizada sem compromisso com 0 processo e o contexto de ensino e aprendizagem e pautada somente na observação do professor em aula. O portfólio pode ser visto como uma forma de intervenção pedagógica que compreende o processo de ensino, aprendizagem e avaliação de maneira conectada, e nega a incoerência de ensinar de uma forma e avaliar de outra, totalmente desconectada do tipo de conhecimento desenvolvido e das estratégias de ensino utilizadas.

Ele também possibilita à comunidade escolar conhecer aquilo que é ensinado e qual o aprendizado dos alunos, tornando-se uma valiosa oportunidade para a área de Educação Física escolar ser reconhecida também como promotora de aprendizagens importantes para o processo educacional geral dos alunos.

Porém, mesmo com tantas vantagens, o portfólio tem suas limitações. Ele exige do professor um tempo maior para analisar criteriosamente o que os alunos expressam nas diferentes propostas de ensino, fornecer seus comentários em cada registro, planejar com vistas à participação ativa, à promoção das parcerias e ao exercício de reflexão e autonomia dos alunos.

Mediante esses apontamentos, compreende-se que é fundamental a formação dos professores para trabalhar com portfólio. Essa formação deve pautar-se na reformulação de conceitos e na integração de ensino, aprendizagem e avaliação. Também é necessária a criação de condições dentro das escolas públicas para que o professor possa implementar a proposta com turmas menos numerosas e número de aulas reduzido, podendo dispor de tempo para a participação em grupos de estudos, a fim de trocar experiências, e também para planejar e avaliar o portfólio dos alunos. Com uma carga horária completa e sem a formação adequada quanto aos pressupostos que embasam esse procedimento de avaliação, torna-se impossível o professor desenvolver o trabalho com portfólio. 


\section{METODOLOGIA}

A investigação das possibilidades do portfólio como um procedimento de avaliação e intervenção em Educação Física escolar, proposta neste trabalho, envolveu os seguintes atores: a professora-pesquisadora e 23 alunos do quarto ano do Ensino Fundamental de um colégio particular da cidade de Guarulhos. A professora-pesquisadora lecionava nesse estabelecimento, e na condição de professora procurava melhorar sua prática pedagógica, por meio de um novo olhar sobre o processo de ensino, aprendizagem e avaliação de seus alunos; na posição de pesquisadora, buscava se aprofundar no processo da própria formação e na investigação sob o enfoque qualitativo.

Para justificar a metodologia utilizada no contexto desta pesquisa, é relevante resgatar seus objetivos iniciais:

a) identificar, interpretar e compreender as representações registradas pelos alunos, tendo como foco a observação da expressão da aprendizagem, das dificuldades e como fazer para melhorar na aula de Educação Física;

b) identificar, interpretar e compreender as possibilidades e limitações do portfólio como prática que oportuniza a avaliação no processo de ensino e aprendizagem na Educação Física escolar;

c) compreender as transformações que as concepções e práticas sofreram ao longo do processo de formação da professora-pesquisadora com a utilização do portfólio.

Seis questões norteadoras embasaram a pesquisa de campo, com a inclusão de procedimentos de coleta e análise de dados de acordo com o enfoque adotado:

1. O portfólio revelou os conhecimentos trabalhados em aula?

2. O portfólio possibilitou aos alunos identificarem as dificuldades de aprendizagem e como fazer para melhorar?

3. A auto-avaliação como mais um procedimento inserido no portfólio dos alunos possibilitou a aprendizagem dos aspectos relacionados à postura de estudante?

4. O portfólio possibilitou à professora reflexão sobre sua prática pedagógica?

5. O portfólio indicou as dificuldades da professora no processo de ensino e aprendizagem? 
6. O portfólio possibilitou à professora conhecimento sobre como melhorar as dificuldades relacionadas ao ensino?

O trabalho de cunho qualitativo considerou as modalidades pesquisa-ação e paradigma indiciário, tendo como contexto o tempo, o espaço e os participantes da pesquisa.

\subsection{A pesquisa qualitativa como enfoque metodológico}

A investigação qualitativa teve origem em diferentes campos. Nos Estados Unidos, na França e na Inglaterra, a partir do século XIX, estudos realizados por fotógrafos, jornalistas, sociólogos e estatísticos que denunciavam as condições degradadas da vida urbana de pessoas menos favorecidas, apontam que empregavam métodos de pesquisa qualitativa como a observação participante, as entrevistas e o registro de campo fotografado. A procedência da pesquisa qualitativa indica, assim, o comprometimento das pessoas em denunciar e promover a transformação social em seu contexto (BOGDAN e BIKLEN, 1994).

Hoje a pesquisa qualitativa tem o desafio de relacionar as necessidades $\mathrm{e}$ objetivos de uma sociedade democrática com vistas à transformação social, contribuindo, assim, para a construção de projetos na busca de soluções para problemas que estejam no âmbito da vida real das pessoas (BOGDAN e BIKLEN, 1994). Segundo RÚBIO (2006, p. 1),

diferentemente da pesquisa quantitativa, considera hard, que tem seu início marcado pelo estudo de um certo número de casos individuais, quantifica fatores segundo um estudo típico, procura por correlações, generaliza o encontrado nos casos particulares pautando-se em procedimentos estatísticos, a pesquisa qualitativa, tida como soft, busca uma compreensão particular daquilo que estuda, respondendo a questões muito particulares. Ela se preocupa, nas ciências humanas, com um nível de realidade que não pode ser quantificado. Ou seja, ela trabalha com o universo de significados, motivos aspirações, crenças, valores e atitudes, o que corresponde a um espaço mais profundo das relações, dos processos e dos fenômenos que não podem ser reduzidos à operacionalização de variáveis.

Nessa perspectiva, esta abordagem de pesquisa caracteriza-se por compreender o fenômeno específico em toda a sua complexidade, sendo os estudos conduzidos com amostras pequenas, orientados pela preocupação central de apreender o processo e não o produto, a partir de dados colhidos no ambiente 
natural em que o fenômeno acontece, estando o pesquisador em contato direto no contexto investigado.

Esse enfoque metodológico pondera as abstrações construídas ao longo da pesquisa e não a priori, como na investigação quantitativa. Explicam BOGDAN e BIKLEN (1994, p.50): "Não se trata de montar um quebra-cabeça cuja forma final conhecemos de antemão. Está-se a construir um quadro que vai ganhando forma à medida que se recolhem e examinam as partes".

Os autores também elucidam que na investigação qualitativa o significado dos acontecimentos é de vital importância. Existe uma preocupação constante em dar voz aos participantes investigados, preocupando-se em desvelar os sentidos que constroem e o modo como interpretam suas experiências no contexto em que estão inseridos. Os dados coletados são um reflexo do diálogo entre o pesquisador e os participantes da pesquisa.

O posicionamento epistemológico ${ }^{16}$ da abordagem qualitativa é manter o foco na compreensão e não na explicação do fenômeno investigado. O pesquisador assume o caráter pessoal da pesquisa e não busca a neutralidade. $O$ conhecimento é visto como uma construção, e não uma descoberta (MARTINS e BICUDO, 1989).

De acordo com esses pressupostos, no processo da presente investigação a pesquisadora buscou a compreensão da realidade vivida pelos participantes: a professora e os alunos. Foi realizada a leitura dos registros e seleção das partes consideradas mais adequadas para a investigação. As informações foram tratadas, procurando dar-Ihes um sentido por meio da teorização adequada que permitia a produção de um conhecimento sobre o portfólio na Educação Física escolar, até então não disponível na área.

Para a construção desse conhecimento, primeiro foi realizada a revisão da literatura sobre o assunto e depois foi desenvolvida uma intervenção didática com os alunos, em que houve a aplicação do portfólio. Nesse momento, foi impossível a produção de um discurso neutro ou natural da pesquisadora na composição dos

\footnotetext{
${ }^{16}$ Segundo GÓMEZ e JIMENEZ (1999), o posicionamento epistemológico da pesquisa qualitativa pode ser entendido como um dos níveis de análise dessa abordagem, o modo como o conhecimento é validado, assumindo uma via indutiva. Nesse sentido, a teorização é fruto do contato do pesquisador com a realidade concreta e com os dados coletados.
} 
dados para análise. $\mathrm{O}$ olhar sobre os dados, o recorte de um elemento em detrimento de outro, a formulação de hipóteses explicativas baseadas nos dados singulares demonstraram as formas de construção do conhecimento da professorapesquisadora com a aplicação do portfólio.

Outro ponto a ser destacado com relação à não-neutralidade da professorapesquisadora é o fato de assumindo os dois papéis no presente estudo. Essa opção está fundamentada nos pressupostos da modalidade de pesquisa qualitativa chamada paradigma indiciário, que será abordada no tópico a seguir.

\subsection{A modalidade de pesquisa utilizada}

\subsubsection{Paradigma indiciário}

Segundo AZANHA (2002), ao longo da história da ciência foram inumeráveis os episódios nos quais, por simples acaso ou por uma atitude de perspicácia do investigador em procurar vestígios para compreender uma determinada situação, houve descobertas inesperadas, que mais tarde foram reconhecidas como teórica ou empiricamente importantes. Considera o autor que essas condições em que a pesquisa enseja descobertas relevantes dão relevo à atuação das gerações mais jovens da comunidade científica, mais permeáveis e receptivas à emergência de novidades. Cita o conceito de serendipity como explicação inicial para esse formato de pesquisa. Pautado em Merton, AZANHA (2002, p.136) expõe que se pode chamar de serendipity a descoberta, a experiência comum da observação de um fato imprevisto e estratégico. Para que ocorra, é necessário um

observador teoricamente sensibilizado capaz de reconhecer nesse fato o ponto de partida para o alcance de um conhecimento sobre uma realidade mais ampla e apenas entremostrada nele. Só para um olhar clínico, um fato vem a ser estratégico.

Embora a expressão serendipity já tivesse sido utilizada por Merton em 1945, AZANHA (2002) expõe que recentemente o historiador italiano Carlo Ginzburg esclareceu que a expressão não deveria ser encarada apenas como uma denominação exótica de ocorrências casuais no contexto da investigação. 0 
paradigma indiciário é uma análise centrada na decifração de vários signos, indícios ou sintomas.

Para GINZBURG (1989), o termo pode ser associado a práticas milenares que visavam, em certas situações, alcançar a partir de indícios o conhecimento não diretamente acessível à experiência humana. Exemplifica com a prática do caçador debruçado sobre o rastro de um animal, o pescador atento ao vento, o sacerdote que examina as vísceras de animais sacrificados. Assinala que esses exemplos não são mais do que práticas que se constituíram ao longo do tempo na tentativa de organizar a observação para conduzir a proposição sobre o não-observado diretamente.

Desse modo, o autor pondera que muitos saberes aparentemente sem nada em comum, como os saberes venatórios, divinatórios, médicos, policiais etc., filiamse a um mesmo modelo de investigação, que chama de paradigma indiciário e que se contrapõe aos modelos buscados pelas ciências físicas desde Galileu.

O paradigma indiciário está fundamentado na observação dos detalhes aparentemente sem importância, se caracteriza como um método de pesquisa de cunho qualitativo que valoriza a singularidade dos resultados e possibilita a reconstrução e a compreensão de uma realidade ou situação complexa, experimentável de forma direta ou não. Essa abordagem tem como proposta a busca de pistas, indícios e sinais revelados no contexto de pesquisa sem desconsiderar a totalidade.

Segundo ESTEBAN (2002, p.5), a proposta metodológica pautada no paradigma indiciário

dá relevância a eventos que permitem a explicitação da diversidade, mesmo quando ele parece ausente. São fatores que permitem novas percepções da realidade, por trazer à tona aspectos subjacentes às atuações imediatamente visíveis, e geram condições favoráveis para uma leitura de nova qualidade do real. A natureza secundária destes elementos faz com que sejam menos controlados, censurados ou adequados ao que se imagina ser o esperado; aponta chaves para se penetrar em áreas ocultas.

A abordagem indiciária possibilita condições para este trabalho investigativo por não se centrar na necessidade e importância da quantidade de dados, mas na qualidade singular das pistas, indícios e sinais revelados que podem assumir sentidos dentro do corpus analisado. Pode facilitar a leitura das informações registradas pela professora-pesquisadora e pelos alunos, que deixam rastros e 
marcas que respondem às perguntas formuladas na pesquisa. Em outras palavras, apreende os pormenores que servem no processo de análise como decifradores do individual e do singular, que desvelam as representações dos participantes da pesquisa.

A essência do método sugere que os indícios sejam examinados de forma atenta, utilizando-se a intuição alta, a perspicácia, o olhar clínico do investigador e se revelem como elos conectivos compondo o tecido discursivo do estudo. AZANHA (2002, p.138) considera que as expressões intuição alta, perspicácia, olhar clínico "apontam para a idéia de que pelo menos uma parte do êxito da prática científica depende do exercício de uma subjetividade privilegiada”. E complementa:

É possível que essa idéia possa parecer desalentadora àqueles para os quais a racionalidade da ciência deveria estar na utilização sistemática de regras claras e objetivas de ordenação da prática científica. Contudo, não há razões fortes para desalentos, pois o reconhecimento da importância do desempenho individual não introduz nenhuma ilogicidade na prática científica, nem o exame dessa passa a ser obrigatoriamente um assunto da psicologia.

O autor expõe que o fato de o paradigma indiciário trabalhar com os dados sem uma ordenação coerente e sem oferecer um cenário visível para sua interpretação não deixa de ser ponderado como conhecimento científico, pois não é a forma como os dados são coletados e revelados na pesquisa que deve ser levada em conta, mas sim a pertinência ou não da aplicação do conhecimento encontrado no contexto investigado.

Neste estudo, foram selecionadas as partes dos registros que apresentavam indícios significativos e que respondiam às perguntas da pesquisa. Houve a organização e tematização dos indícios que sustentavam ou refutavam as questões formuladas no desenvolvimento da pesquisa. A partir disso foi construída a discussão das observações realizadas diretamente da fonte, buscando a compreensão do que se observou nos registros, abarcando as perspectivas dos participantes da pesquisa.

\subsection{O espaço, o tempo e os atores da investigação}

\subsubsection{O espaço da investigação}


O colégio em que se desenvolveu esta investigação foi fundado em 1979 e desde então efetiva uma proposta de educação de vanguarda na cidade de Guarulhos.

É constituído de três unidades. A unidade I é o local em que a pesquisa foi desenvolvida. Atende o ensino fundamental I e II e o ensino médio. Compreende uma área cerca de 5 mil metros quadrados, com laboratórios de informática, ciências, idiomas, sala ambiente de artes e música, biblioteca, auditório multimídia, duas quadras poliesportivas (uma coberta e outra ao ar livre), parque infantil, cantina com amplo espaço para refeições, salas de coordenação, direção e atendimento a pais, mães e alunos(as), sala de professores(as), espaço especial para refeição de professores(as) e funcionários(as), sala de ginástica, áreas de convivência.

Os princípios educacionais que o colégio segue compreendem a preparação de pessoas para enfrentar os desafios do mundo atual, o que envolve, além da informação, o desenvolvimento de competências e habilidades que possibilitem ao indivíduo lidar com o universo de opções que se abrem a sua frente em cada desafio. Estrutura sua proposta pedagógica, baseando-se na construção do conhecimento como meta considerada possível e necessária, e desenvolve projetos de trabalho em espaços idealizados para a prática de atividades educativas. Os objetivos educacionais do colégio são:

- formar indivíduos plenos para os(as) quais o conteúdo escolar tenha significado claro na vida cotidiana;

- promover a compreensão da extensão, profundidade e relação dos conhecimentos abordados nas diferentes áreas de estudo;

- desenvolver a capacidade dos(as) alunos(as) de identificar e formular problemas, de utilizar adequadamente fontes, dados e evidências, de elaborar e testar hipóteses, de chegar a conclusões adequadas a partir dos conhecimentos acumulados na pesquisa, de construir argumentos lógicos relacionando causas e efeitos e de socializar o processo de investigação e seus resultados com o grupo;

- promover a aquisição de hábitos saudáveis através da valorização da prática de esportes e da expressão corporal como forma de comunicação; 
- direcionar os esforços dos(as) alunos(as) para os objetivos do grupo, sem que renunciem à sua individualidade;

- construir as condições e o instrumental necessários para que os(as) alunos(as) tenham uma efetiva participação social e política, condição essencial para 0 exercício da cidadania, tornando-os(as) aptos(as) a avaliar criticamente a sociedade em que vivem e, em conseqüência, contribuindo no rumo da democracia e da não-exclusão;

- formar pessoas capazes de perceber e avaliar seu papel e o do(a) outro(a), em diferentes situações e que desenvolvam a capacidade de convivência e de respeito às diferenças raciais e étnicas.

Para atingir esses objetivos, o colégio seleciona profissionais capacitados(as) e mantém um processo de formação continuada de seus/suas educadores(as), contando para isso com dois instrumentos centrais: as reuniões periódicas de discussão, estruturação e balanço das atividades pedagógicas e o Centro de Estudos do próprio colégio, que realiza atividades formativas permanentes ${ }^{17}$.

\subsubsection{O tempo da investigação}

Esta pesquisa aconteceu no período de aulas de Educação Física da turma investigada. Os alunos já conheciam a professora dos anos anteriores, bem como a proposta de aprender por meio de projetos nas aulas de Educação Física. O projeto sobre jogos iniciou-se no trimestre que correspondeu aos meses de março, abril e maio de 2006.

A pesquisa foi organizada em quatro fases: 1) revisão da literatura e cumprimento de créditos por meio de disciplinas de pós-graduação; 2) a imersão no contexto, a pesquisa da professora com a aplicação do projeto, utilizando o portfólio com os alunos; 3) busca de indícios que respondessem às perguntas norteadoras do estudo nas notas de campo da professora-pesquisadora e nas observações sobre 0 portfólio dos alunos; 4) análise e interpretação dos indícios encontrados.

\footnotetext{
${ }^{17}$ Informações retiradas do site do colégio.
} 
$\mathrm{Na}$ primeira fase, a professora-pesquisadora teve como objetivo buscar embasamento teórico para compreender o problema da avaliação na Educação e na Educação Física escolar. Nesse caminho, buscou uma via para trabalhar o processo de ensino, aprendizagem e avaliação de maneira coerente dentro da escola em que leciona. Com os vestígios históricos da avaliação, observou as linhas pedagógicas sobre as quais os professores construíram seus processos e procedimentos de avaliação. A revisão da literatura também apontou que com uma prática pedagógica definida é possível realizar avaliações que reflitam a prática da sala de aula e, conseqüentemente, o processo de ensino-aprendizagem. Ficou claro que as propostas inovadoras em Educação enfatizam a necessidade de os alunos caminharem juntamente com 0 professor durante o processo de ensinoaprendizagem, não sendo apenas repetidores de movimentos, e sim compreendendo que a Educação Física possui um corpo de conhecimentos que também são importantes para o processo de formação básica escolar. Além disso, tornou-se evidente que a avaliação não deve ser orientada por um caráter punitivo, como forma de castigo e em nome da disciplina, e sim em favor da aprendizagem (PERRENOUD, 1999).

Em síntese, a revisão da literatura apontou que é preciso mudar o modo de pensar do professor e da comunidade escolar, passando a ver o ensino, a aprendizagem e conseqüentemente a avaliação a partir de suas matrizes reflexivas e adequando-as à realidade de ensino na qual o professor está inserido, pois só assim será possível ocorrerem transformações nesse cenário.

$\mathrm{Na}$ segunda fase, a professora-pesquisadora organizou a intervenção didática e realizou a proposta do projeto de jogos com os alunos no período da manhã, durante três meses. O objetivo dessa etapa foi a imersão da professorapesquisadora no próprio cotidiano pedagógico da turma investigada para 0 estabelecimento de vínculos com o alunos e a aplicação do projeto e do portfólio, contemplando, ainda, o processo de autoformação, na prática, com relação ao assunto.

As fontes de dados foram: observação participante, caderno de campo da professora-pesquisadora sobre as aulas, envolvimento dos alunos, prática 
pedagógica, filmagem das aulas e apontamentos sobre os registros dos alunos que compunham o portfólio ${ }^{18}$.

As duas últimas fases serão descritas de maneira pormenorizada no tópico relativo à coleta e análise de dados da pesquisa.

\subsubsection{Os atores da investigação}

Os participantes da pesquisa foram 23 alunos do quarto ano do ensino fundamental e a professora-pesquisadora, que atuou como professora de Educação Física nessa mesma instituição de ensino particular.

Os alunos caracterizam-se por terem entre nove e dez anos e já estarem acostumados às tarefas com perfil intelectual que caracterizam a escola, já que a maioria estuda ali desde a educação infantil e tem aula de Educação Física com a mesma professora desde os 5 anos de idade.

A professora-pesquisadora foi formada no curso de licenciatura em Educação Física, em 1999; fez especialização lato sensu em Educação Física escolar, em 2000; faz parte de alguns grupos de estudo sobre Educação, e específicos de prática pedagógica em Educação Física escolar, como o NEPICC (Núcleo de Estudos e Pesquisas em Inteligência Corporal Cinestésica), que a levou a conhecer o portfólio. Ingressou no mestrado em sua área de atuação profissional, em 2005. O tempo de experiência como professora de Educação Física no contexto escolar compreende um período de nove anos. No colégio investigado, trabalha desde 2002.

\subsection{Os instrumentos de coleta e os procedimentos de análise dos dados}

A multiplicidade de fontes de dados é um dos grandes desafios da análise dos resultados da pesquisa qualitativa (BOGDAN \& BIKLEN, 1994; MARTINS \& BICUDO,1989). Nas modalidades de pesquisa-ação e paradigma indiciário, entendese que a análise dos dados implica encontrar significados que favoreçam a

\footnotetext{
${ }^{18}$ A descrição da proposta de trabalho seguida no projeto está exposta no ANEXO I.
} 
compreensão das situações vividas pelos participantes, a fim de buscar novas respostas para os desafios e a transformação das práticas correntes.

A presente pesquisa utilizou-se de uma multiplicidade de fontes de dados e de diferentes estratégias de coleta desses dados. Foram realizados recortes sobre os registros que compuseram o portfólio dos alunos e também o diário de campo da professora-pesquisadora. Nos registros dos alunos os enfoques foram voltados às atividades e experiências das aulas, tais como: o que aprenderam, as dificuldades encontradas, o que foi feito para melhorar. No diário de campo da professorapesquisadora, os registros ou notas de cunho etnográfico foram organizados pelo fio condutor narrativo, abarcando a dispersão de acontecimentos do dia-a-dia do campo investigado. CARIA (2002, p. 26) explica que essa técnica de coleta de dados "ordena não só o dado descritivo, mas também uma série de cognições e de sentimentos que constantemente se produzem no contato permanente com a vida social local".

Após cada aula da intervenção proposta, as observações sobre os acontecimentos foram registradas pela professora-pesquisadora, utilizando a técnica de notas de campo descrita acima. Elas foram feitas por meio da escrita e, após as aulas, com o apoio de filmagens para obter mais detalhes.

Para a análise desses registros, foi feita a leitura com foco na busca de indícios, assim como sugere GINZBURG (1999) no paradigma indiciário, os quais deveriam apresentar relação com as perguntas do estudo. Nas próprias notas de campo e nas notas de observação sobre os registros dos alunos foram destacados em negrito os vestígios encontrados. Os trechos com os indícios destacados em negrito foram colocados abaixo das questões norteadoras. Foi elaborada a interpretação e a discussão dos resultados, segundo as características do quadro teórico do estudo, daquilo que foi manifesto empiricamente e representado nos registros pelos participantes e pelo objetivo da pesquisa. Para cada pergunta norteadora foi organizado um corpo de texto a partir do qual surgiram algumas categorias ou tema de análise, o que facilitou a discussão sobre o que diziam os dados. 


\section{$5 \quad$ ANÁLISE E DISCUSSÃO DOS DADOS}

A análise dos dados foi realizada a partir da seleção de indícios que apresentavam relações com as questões norteadoras deste estudo. Os indícios foram retirados das notas de campo da professora e de suas observações sobre os registros dos alunos. Eles foram organizados em categorias, de acordo com a natureza das questões propostas neste estudo, organizadas em tabelas numeradas em ordem crescente - e enunciados denominados pelo número da questão a que se referem e uma letra minúscula, que identifica cada recorte selecionado (por exemplo, 1a, 1b etc.).

A identificação dos alunos foi feita por meio da atribuição de um número acompanhado de letra maiúscula entre parênteses, correspondente à(s) inicial(is) de seus nomes: por exemplo, aluno 13 (J). Optou-se por essa forma de indicação para facilitar a exposição dos indícios encontrados no decorrer da análise e interpretação do material investigado.

\subsection{A primeira pergunta norteadora: 0 portfólio revelou os conhecimentos trabalhados em aula?}

Para iniciar a investigação e análise dos indícios relacionados à questão supracitada, considera-se necessário esclarecer que o conhecimento trabalhado na intervenção didática desenvolvida com o portfólio na pesquisa de campo corroborou o que COLL e MARTíN (1998) expõem sobre o trabalho escolar vincular-se ao ensino de conteúdos que facilitem o desenvolvimento de aprendizagens específicas dos alunos. Nesse sentido, a noção de conteúdo implica seleção de formas ou saberes culturais, conceitos, explicações, raciocínios, habilidades, linguagens, valores, crenças, sentimentos, atitudes, interesses etc.

Nas diferentes formas de classificar essa diversidade de conteúdos, Coll e seus colaboradores propõem que eles sejam agrupados segundo uma tipologia tripla, a saber: conceitual, procedimental e atitudinal. Essa classificação corresponde, respectivamente, às perguntas "o que se deve saber?" (dimensão conceitual), "o que se deve saber fazer?" (dimensão procedimental), e "como se deve ser?" (dimensão 
atitudinal). Considera-se esse posicionamento fundamental para conseguir alcançar a perspectiva educacional mais eficiente nos programas de Educação Física ao abordar os temas da cultura corporal.

Como o tema trabalhado na pesquisa de campo foi o jogo, será realizada uma explicação mais específica sobre o que quer dizer cada uma dessas dimensões de conteúdo, tendo o tema como exemplo.

Segundo FERRAZ (2004), do ponto de vista factual e conceitual, aprender jogos significa conhecer sua história e suas regras, além de trazer implicações oriundas dessa prática social analisada pelas disciplinas científicas, tais como a filosofia, sociologia, antropologia, psicologia, nutrição, biomecânica, fisiologia, entre outras. Obviamente, deve-se considerar a profundidade desses conhecimentos em função das características de crescimento de desenvolvimento do aluno. Por exemplo, no caso deste estudo, em que os participantes da pesquisa estavam no quarto ano do Ensino Fundamental, a ênfase pode recair em fatos e conceitos relacionados a implicações práticas: de onde surgiram os jogos, como são realizados pelas crianças de outras regiões, quais as habilidades motoras e as atitudes exigidas.

Com relação à dimensão procedimental, o aluno aprende a jogar (como jogar), desenvolvendo a capacidade de controlar seus movimentos. Diz respeito à capacidade de se mover de forma efetiva numa variedade de atividades motoras crescentemente complexas. Em jogos com bola os alunos podem, por exemplo, aprender a solucionar os problemas de ataque e defesa, colocando em prática diferentes estratégias, como, por exemplo, proteger a bola ou passá-la para um companheiro que se desloca. Nessa dimensão, aprender a se mover envolve tentar, praticar, pensar, planejar, avaliar e decidir.

$\mathrm{Na}$ dimensão atitudinal, em sentido amplo, o jogo é utilizado como um meio para alcançar um fim que não é o próprio jogo, mas, por exemplo, a possibilidade de o aluno, aprendendo sobre seu potencial e suas limitações, adquirir atitudes de perseverança, assumindo riscos e reconhecendo que as limitações podem ser melhoradas nesse processo. Engajando-se nas relações de mutualidade com outros, baseado em valores democráticos, poderá estabelecer comparações e aprender a 
respeitar as capacidades e limitações dos outros. Em sentido específico, o respeito às regras do jogo é um importante aspecto dessa dimensão do conteúdo.

A preocupação com as atitudes no ensino de jogos em Educação Física escolar deve-se ao fato de que os valores e as atitudes impregnam toda a experiência educacional e sua "transmissão" acontece mesmo que não se constitua em conteúdo explicitamente educacional.

A partir do exposto, considera-se que a distinção dos três tipos de conteúdo é relevante para este estudo, porque possibilita compreender o desenvolvimento desses conhecimentos e adequar os métodos, as estratégias didáticas e técnicas de avaliação, de modo a serem coerentes com a natureza dos conhecimentos a serem desenvolvidos, pois eles apresentam características diferentes, como já foi mencionado na revisão de literatura.

Essas explicações oferecem subsídios para a análise e discussão dos dados relacionados à primeira questão norteadora. Esses dados foram extraídos de 17 tabelas de observação da professora sobre os registros diários dos alunos, e neles se faz presente grande quantidade de conhecimentos que tendem à identificação e explicação dos conteúdos trabalhados nas aulas. Desse universo foram selecionadas as cinco primeiras tabelas para serem analisadas em termos dos conteúdos propostos aos alunos, descartando-se as informações repetidas ou redundantes.

As tabelas demonstram que os alunos identificam e explicam alguns elementos ou parte dos conteúdos que foram trabalhados pela professora durante a intervenção didática. Um exemplo disso é a aula 5 , que abordou como conteúdo elementos sobre como jogar, as habilidades que exigiam os jogos e as regras combinadas. O registro da aluna 1 (A.B.) traz: Identifica os nomes dos jogos: 1) pega-pega cocorô; 2) floresta; 3) barra-manteiga [Tabela 32]. Observa-se que ela identificou o nome dos jogos de perseguição que executou, mas não apontou nenhum outro conteúdo abordado na aula. A explicação encontrada para esse indício pauta-se em SIERRA e CARRETERO (1996), ao afirmarem que os alunos expressam os conteúdos selecionando os conhecimentos mais relevantes para os seus esquemas. 
Nos registros dos alunos observa-se o destaque dado à manifestação de conhecimentos que identificam o nome do jogo ou assunto trabalhado, conteúdos a respeito de como compreenderam o que é jogo e como jogaram.

Com relação ao primeiro item (nome do jogo ou assunto trabalhado), encontram-se indícios que são elucidados pelas seguintes expressões da professora: Aluno 3 (C.): Identifica os jogos alerta e futebol escolhidos na aula [Tabela 25]. Aluna 21 (N.M.): A aula tratou sobre algumas hipóteses para a origem do jogo [Tabela 26].

Aluna 1 (A.B.): Identifica os jogos: 1) pega-pega cocorô; 2) floresta; 3) barramanteiga aplicados na aula [Tabela 27].

Entende-se que a expressão de conhecimento revelada pelos alunos nesses recortes relaciona-se à dimensão factual que, segundo POZO (2000), significa ser capaz de identificar, reconhecer, classificar. Implica uma aprendizagem memorística que requer a capacidade de recordar o assunto trabalhado em aula. Nesse sentido, observa-se nos recortes expostos abaixo que os alunos repetiram os temas trabalhados em aula e não realizaram reflexão sobre o que compreenderam com relação a tais assuntos:

Alunos 3 (C.) e 5 (F.): Identifica o nome do jogo que executou: pique-bandeira [Tabela 24];

Aluno 3 (C.): Identifica os jogos alerta e futebol escolhidos na aula. [Tabela 25] ${ }^{19}$; Aluno 5 (F.): (...) ter surgido da necessidade das crianças mostrarem o que queriam [Tabela 26];

Aluno 13 (J.): (...) podem ter surgido na Grécia antiga e se espalharam pelo mundo [Tabela 26] ${ }^{20}$.

Mediante esses indícios, entende-se que houve a expressão de aprendizagem repetitiva do que foi visto na aula. Pautando-se em POZO (2002, p.123), essa forma de aprendizagem produz resultados limitados ao processo educacional dos alunos porque "se criam hábitos passivos e receptivos", e os alunos se acostumam a fornecer respostas fáceis sem refletir sobre o que aprenderam.

${ }^{19}$ Foram encontrados outros indícios com o mesmo direcionamento, que podem ser vistos na Tabela 25, relativos aos alunos 4 (F.), 8 (G.), 11 (I.C.), 18 (L.), 19 (L.), 20 (M.) e 21 (N.M.).

${ }^{20}$ Outros indícios foram encontrados e podem ser vistos na Tabela 26, relativos aos alunos 1 (A.B.), 2 (B.), 8 (G.), 10 (I.C.), 11 (I.C.), 18 (L.), 19 (L.), 21 (N.M.), 22 (N.C.) e 23 (N.). 
A manifestação desse tipo de conteúdo pode ter ocorrido porque esses foram os primeiros registros feitos pelos alunos: a compreensão sobre como deveriam registrar era limitada e não havia referências suficientes para produzir os registros. Outro motivo pode ser a falta de interesse dos alunos para fazer o registro, já que a motivação estava voltada para a prática dos jogos, e não para a formalização do que eles haviam aprendido. Finalmente, pode ter havido falta de clareza sobre os critérios destinados a orientar sobre o que registrar.

Vários autores ${ }^{21}$, no contexto do portfólio, ressaltam que é imprescindível os alunos conhecerem e compreenderem os critérios para a produção dos registros, a fim de evitar que eles registrem conhecimentos sem base em reflexão, como foi o caso dos conhecimentos factuais manifestados pelos alunos participantes desta pesquisa. Os autores consideram que assim se garante a prática de um dos pilares da proposta de avaliação com portfólio, que são: a reflexão e a explicitação sobre o que se faz, revelando momentos relevantes para conhecer o processo de reconstrução e reelaboração do conhecimento. VILLAS BOAS (2004) complementa essa discussão, lembrando que os alunos, mesmo sendo norteados por critérios, poderão registrar elementos díspares acerca do foi proposto, com enfoque mais em um conteúdo do que em outro.

Outros indícios relacionados à explicação dos alunos sobre o que compreenderam do tema jogo sinalizam sua compreensão conceitual sobre 0 assunto, como indicam os trechos extraídos das tabelas:

Aluna 10 (I.C.): É essencial na infância; podem ter objetos, como a queimada, ou não, como o pega-pega; também, é importante para o desenvolvimento do nosso corpo [Tabela 23];

Aluno 20 (M.): (...) mostrou 3 exemplos de onde surgiram os jogos. A $1 \underline{0}$ foi que surgiram a muito na Grécia, 2 o foi que surgiram na Europa, a 3o foi que surgiram da necessidade das próprias crianças [Tabela 26].

Segundo POZO (2000), ser capaz de descrever, comparar objetos, acontecimentos ou idéias implicam uma aprendizagem compreensiva que exige a capacidade de interpretar, explicar e significar algo. Os indícios acima demonstram

${ }^{21}$ VILLAS BOAS (2004); MARTIN-KNIEP (2001) e MELOGRANO (1996). 
conhecimentos conceituais indicados nos registros dos alunos, explicitados pela descrição das principais idéias do conteúdo desenvolvido em aula. Eles também demonstram que a compreensão expressa pelos alunos não é igual, já que estes atribuem diferentes enfoques e significados aos conhecimentos que foram ensinados.

Nos dados levantados das notas de campo é possível verificar a correspondência entre os registros e os conteúdos que a professora planejou e trabalhou em aula. Assim, compreende-se a prática dos registros no trabalho com portfólio, mesmo expressando uma variedade de conhecimentos, possibilita ao professor avaliar se o essencial do conteúdo esteve presente no processo de ensino e aprendizagem. Tal observação está indicada nos trechos recortados da Tabela 23 , expostos a seguir:

Conteúdo trabalhado em aula: Definições sobre o que é jogo. Levantamento de características sobre o jogo;

Aluno 4 (F.): Não importa perder ou ganhar, o legal é participar ;

Aluna 19 (L.): Diverte as pessoas; é necessário respeitar as suas regras.

As expressões de conhecimentos dos alunos que se considerou abarcar com a dimensão procedimental apontaram o conjunto de ações ordenadas para atingir os objetivos dos jogos que lhes foram propostos, como pode ser observado nas seguintes expressões:

Aluna 15 (J.P.): (...) dois grupos tinham que atacar o campo da outra equipe e pegar a bola e levar para o seu campo, mas se a pessoa te pegar você vira estátua e tem que esperar alguém te salvar. Acaba o jogo quando alguém leva a bola até o seu campo [Tabela 24];

Aluna 22 (N.C.): 0 jogo alerta começava com a bola passando para os amigos em roda, quando caía quem pegava a bola tinha que gritar "Alerta". No futebol agente tinha que passar a bola para os amigos e quando chegava perto do gol tentava chutar forte para fazer gol [Tabela 25].

Nota-se que os aspectos mencionados pelos alunos referem-se aos passos que executaram nos jogos, envolvendo a descrição das técnicas e das estratégias aplicadas. De acordo com COLL e MARTíN (1998), declarar de modo ordenado as técnicas e as estratégias utilizadas em determinada situação não é suficiente para a 
aprendizagem de conteúdos procedimentais. Os autores advertem que o saber-fazer é indispensável para a aplicação prática desse conhecimento em diferentes situações. Não é possível avaliar o conhecimento dos alunos na perspectiva procedimental apenas porque sabem declarar procedimentos; é necessário vê-los colocar esses procedimentos em prática. Nessa perspectiva, os autores apontam que a observação do professor em aula se torna fundamental para avaliar efetivamente esse tipo de conteúdo.

Em linhas gerais, percebeu-se nos registros dos alunos a revelação de conhecimentos trabalhados em aula, mas esses foram apresentados de forma fragmentada e de acordo com os seus esquemas de representação e significação. Mediante essa observação, foi possível compreender que as informações contidas nos registros que farão parte do portfólio dos alunos devem ser interpretadas à luz das palavras deles, tendo em vista a coerência com o que foi proposto e combinado em aula. Esse cuidado possibilita ao professor, aos alunos e leitores do portfólio focalizar a apreciação dos conhecimentos revelados.

Em síntese, a prática do portfólio permitiu à professora e aos alunos tomarem conhecimento dos conteúdos ensinados e aprendidos no decorrer do processo, bem como daqueles que necessitavam ser retomados por meio de outras formas de ensino. Essa possibilidade do portfólio pode ser considerada um meio gerador de aprendizagem para a professora, já que estimula a busca por novas estratégias de ensino para melhorar a prática pedagógica com vistas à aprendizagem dos alunos.

\subsection{A segunda pergunta norteadora: 0 portfólio possibilitou aos alunos identificar as dificuldades de aprendizagem e como fazer para melhorá-las?}

A importância de os alunos identificarem as dificuldades encontradas e o que fazer para melhorá-las consiste na oportunidade oferecida para atuarem como investigadores de si mesmos e buscar alternativas para solucionar os problemas que enfrentam no decorrer das aulas.

$\mathrm{Na}$ Educação Física escolar essa identificação pode auxiliar os alunos no julgamento de suas aprendizagens (motoras, cognitivas e atitudinais) e na compreensão de como melhorá-las, visto que a quantidade de conteúdos que 
compõem um programa de ensino na área é extensa, considerando-se o tempo disponível de aula propriamente dito. Assim, a meta de aprender a aprender torna-se relevante, uma vez que os alunos aprendem a pensar e buscar soluções para seus problemas, ou seja, passam a procurar conhecimentos que atendam a suas necessidades específicas (FERRAZ e FLORES, 2004).

Os registros dos alunos trazem expostos os aspectos em que eles precisavam melhorar e as soluções para tais dificuldades. A leitura dos indícios aponta uma multiplicidade de informações que, para serem mais bem compreendidas, foram organizadas e tematizadas de acordo com os conteúdos das aulas, a saber: jogos de correr; de saltar e volear; atitudes que favorecem a solução de problemas por meio do diálogo; persistência e envolvimento nas propostas de aula.

\subsubsection{Jogos de correr}

No conteúdo jogos de correr observa-se que os alunos reconhecem o problema e os aspectos que precisavam ser melhorados, como a velocidade e os problemas dos jogos (ausência de desafios e não-envolvimento). Com relação à essas observações, é possível exemplificar com os seguintes recortes:

Aluno 4 (F.): (...) Senti dificuldade no [jogo] floresta ao desviar dos colegas, eu preciso de mais velocidade [Tabela 29];

Aluna 11 (I.C.): Expõe um problema: Eu vi gente que andava ao invés de correr se continuar assim não vou ser pega nunca. As dicas que usou para melhorar as suas dificuldades: Não ficar parado, correr com velocidade para não ser pego [Tabela 10] ${ }^{22}$;

Aluno 5 (F.): (...) o objetivo era correr e na brincadeira tinham 2 pegadores, aí ficou muito fácil, então [foram inseridos mais pegadores] tiveram muitos pegadores e aí todo mundo correu bastante [Tabela 32];

\footnotetext{
${ }^{22}$ Foram encontrados outros indícios com o mesmo direcionamento, os quais podem ser vistos na Tabela 32, referentes aos alunos 2 (B.), 7 (G.R.), 8 (G.), 12 (J.), 14 (J.B.) e 18 (L.), e na Tabela 33, alunos 10 (I.C.), 16 (K.), 17 (L.) e 21 (N.M.).
} 
Aluno 16 (K.): Expõe: um pegador era pouco para participar mais e correr mais, quando colocamos mais 4 pegadores resolvemos o problema deste jogo $[\text { Tabela 33 }]^{23}$.

Os indícios sinalizam que foi representativa para os alunos a solução de inserir mais pegadores para melhorar a prática dos jogos de correr e a habilidade da corrida em velocidade.

\subsubsection{Jogos de saltar}

No conteúdo jogos de saltar, observa-se que os alunos identificam os problemas para a execução da habilidade motora de saltar em distância e em altura e os conhecimentos que poderiam ajudá-los na evolução do saltar, como pode ser visto nos enunciados a seguir, extraídos da Tabela 36:

Aluno 4 (F.): As dificuldades encontradas foram: saltar a cela numa altura maior. Expõe que aprendeu uma dica para melhorar o saltar: Pegar mais impulso com a corrida e prestar atenção na altura e na distância que preciso saltar ${ }^{24}$;

Aluno 5 (F.): Expõe: Às vezes, quando eu saltava pisava nos bastões e escorregava. Eu resolvi este problema, só quando diminuí a distância entre os bastões quando ia saltar;

Aluno 7 (G.R.): Diz que teve dificuldade no pula-sela por causa dos bastões que havia entre a sela. Expõe: Melhorei nesta parte do jogo quando pude saltar de outras maneiras.

Os alunos explicitam conhecimentos que se mostram apropriados para diminuir as dificuldades apontadas, especialmente no que diz respeito aos aspectos perceptivos motores da habilidade de saltar. Já na fala do aluno 7 (G.R.) pode-se observar que ele reconhece um procedimento de ensino usado pela professora como

\footnotetext{
${ }^{23}$ Existem outros indícios com o mesmo direcionamento, que podem ser vistos na Tabela 32 , referentes aos alunos 8 (G.) e 15 (J.P.), e na Tabela 33 referentes aos alunos 1 (A.B.), 7 (G.R.), 10 (I.C.) e 18 (L.).

${ }^{24}$ Também há vestígios que sinalizam essa perspectiva na Tabela 36, referentes aos alunos 11 (I.C.), 12 (J.), 14 (J.B.), 16 (K.) e 22 (N.C.). Na Tabela 37, os indícios referentes aos alunos 2 (B.) e 5 (F.). $\mathrm{Na}$ Tabela 38, indícios referentes aos alunos 2 (B.), 5 (F.), 6 (G.B.), 12 (J.), 16 (K.) e 22 (N.C.).
} 
elemento importante para a execução da habilidade de saltar em altura no jogo pulasela: saltar de outras maneiras ${ }^{25}$.

Percebe-se, a partir dos indícios selecionados, que para cada problema ou dificuldade encontrada pelos alunos existiu uma nova modalidade de resolução construída por eles ou sugerida pela professora.

\subsubsection{Jogos de volear}

Sobre os jogos de volear, os seguintes indícios são considerados representativos:

Aluno 23 (N.): Senti dificuldades para receber bexiga e volear por causa do vento, mas isso foi resolvido mudando o jogo em dupla para outro que a gente jogou sozinho [Tabela 39];

Aluna 11 (I.C.): A dificuldade para volear foi diminuída tentando por em prática as seguintes dicas: se o voleio é sozinho deve deixar a mão perto para bater novamente no objeto; se o voleio for feito em dupla é necessário ir até o objeto e volear mirando no colega [Tabela 40];

Aluna 18 (L.): A dificuldade para volear foi diminuída ao tentar volear usando o meio da mão para bater na bola, bexiga ou peteca; usar os dedos para direcionar o voleio com a bola de borracha e não ficar parado [Tabela 40] ${ }^{26}$.

$\mathrm{Na}$ primeira expressão observa-se que o aluno considerou a intervenção da professora como um fator positivo, que possibilitou atenuar a dificuldade da atividade proposta: inicialmente volear em dupla, com o vento atrapalhando, e depois sozinho.

Já as expressões seguintes apontam as dicas de aprendizagem que foram fornecidas pela professora ou construídas pelos próprios alunos por meio de palavrachave que se relacionavam aos aspectos essenciais das habilidades motoras executadas.

\footnotetext{
${ }^{25}$ Esse mesmo indício é expresso na Tabela 36, no registro da aluna 9 (I.).

${ }^{26}$ Há outros indícios em que os alunos revelam conhecimentos sobre o que fazer para melhorar a habilidade de volear, expressos na Tabela 31, referentes às alunas 10 (I.C.) e 19 (L.); Tabela 39, alunos 2 (B.), 6 (G.B.), 9 (I.), 11 (I.C.), 14 (J.B.), 15 (J.P.) e 19 (L.); Tabela 40, alunos 13 (J.), 16 (K.), 17 (L.), 19 (L.) e 22 (N.C.); Tabela 41, alunos 1 (A.B.), 2 (B.), 3 (C.), 4 (F.), 5 (F.), 6 (G.B.), 10 (I.C.), 11 (I.C.), 12 (J.), 13 (J.), 14 (J.B.), 15 (J.P.), 16 (K.), 20 (M.), 21 (N.M.) e 22 (N.C.).
} 


\subsubsection{Atitudes que favorecem a solução de problemas por meio do diálogo}

Observaram-se os seguintes indícios relacionados à solução de problemas nos registros dos alunos:

Aluna 10 (I.C.): O problema foi no quebra-canela, as pessoas seguravam muito alto o bastão. Isto foi resolvido a partir do momento que pudemos dizer qual a melhor altura para cada um [Tabela 30];

Aluna 22 (N.M.): Quando algum amigo não respeitava as regras eu tentava conversar com ele porque isso atrapalhava o jogo [Tabela 32] ${ }^{27}$;

Aluna 10 (I.C.): Tinham pessoas que não aceitavam que eram pegas. A gente conversou e entrou num acordo com o grupo após pedirem tempo no jogo para resolver este problema [Tabela 34].

Os indícios revelam que os alunos conseguem reconhecer atitudes dos colegas, tais como a falta de cooperação e o desrespeito às regras, que prejudicaram a sua aprendizagem e a do grupo de maneira geral. Ao lado da identificação dessas atitudes negativas eles expõem o que fizeram para resolver os problemas, pontuando a importância do diálogo e da argumentação, em vez de brigar, como freqüentemente ocorria.

Ao reconhecerem os problemas relacionados às atitudes dos colegas, os alunos demonstraram que o objeto (jogo) era um espaço importante e sério para eles, por isso a violação das regras combinadas era considerada falta grave. As formas de solução encontradas pelos alunos evidenciam em seus registros que foram importantes para eles, pois se dispuseram a refletir sobre os problemas e tomar decisões, uma vez que eram instigados a pensar sobre os conflitos e procurar uma forma de resolvê-los.

\subsubsection{A atitude de persistir frente às dificuldades}

Observaram-se sobre esse aspecto os indícios extraídos da Tabela 37:

\footnotetext{
${ }^{27}$ Há o apontamento de outros indícios na Tabela 30, referentes às alunas 17 (L.) e 21 (N.C.); Tabela 32, aluna 19 (L.); Tabela 33, alunos 7 (G.R.) e 21 (N.M.); Tabela 35, alunas 1 (A.B.) e 10 (I.C.); Tabela 36, aluna 9 (I.); Tabela 37, aluna 10 (I.C.); Tabela 41, alunos 2 (B.), 5 (F.) e 13 (J.).
} 
Aluno 9 (I.): Expõe o problema dessa aula: as pessoas que desistiam nas primeiras tentativas. Diz a solução: Entender que é preciso perder o medo e não desistir;

Aluna 10 (I.C.): Expõe que um problema foi o momento em que uma menina enroscou o pé na corda e não queria mais participar. Diz que isso foi resolvido por meio da conversa entre a professora e o grupo: Concluímos que se não tentarmos jamais conseguiremos superar novos desafios ${ }^{28}$.

A observação desses trechos demonstra o reconhecimento da necessidade de se comprometer com as propostas da aula e ter persistência para transpor os limites encontrados e vencer os desafios.

Em linhas gerais, ao acreditar numa avaliação que envolve o diagnóstico e a escolha de ações que promovam a melhoria das dificuldades encontradas no processo de aprendizagem, observou-se que a prática dos registros no trabalho com portfólio confirmou essa perspectiva. Infere-se o envolvimento dos alunos no processo de reflexão sobre seus acertos, problemas e dificuldades, bem como a busca de recursos e a criação de novas possibilidades de ação para a tomada de decisões sobre o que fazer para superar os obstáculos. A reflexão e os registros demonstraram o processo de reconstrução dos problemas e a busca de estratégias para a superação das dificuldades vividas pelos alunos.

Assim, o número reduzido de aulas e o pouco tempo de prática dos alunos em Educação Física no contexto escolar não comprometem os objetivos da disciplina, pois o aluno pode levar para os contextos de seu tempo livre os conhecimentos adquiridos em aula. Em outras palavras percebeu-se que à medida que se debate $e$ se questiona o que aprendeu ou não e o que fazer para melhorar, o aluno percebe a importância de sua participação no processo de aprendizagem, levando tais conhecimentos a outros contextos.

Do ponto de vista do professor, a observação dos registros possibilita a compreensão dos problemas e dificuldades encontrados pelos alunos e como eles enfrentam os desafios, isso favorece a construção de intervenções mais adequadas.

\footnotetext{
${ }^{28}$ Outros indícios na Tabela 35, aluno 8 (G.); Tabela 37, alunas 1 (A.B.) e 5 (F.); Tabela 38, alunos 9 (I.) e 12 (J.); Tabela 39, aluno 2 (B.).
} 
5.3 A terceira pergunta norteadora: A auto-avaliação como mais um instrumento inserido no portfólio dos alunos possibilitou a aprendizagem dos aspectos relacionados à postura de estudante?

A auto-avaliação é um tipo de avaliação que deve permitir ao aluno participar "de modo ativo de sua própria avaliação para ter ciência de seu desempenho e refletir conscientemente sobre como alcançar a melhoria de sua aprendizagem" (SANTOS, 2005, p.25).

Para entender por que esse procedimento (a auto-avaliação) foi utilizado, é necessário saber quando e por que ele foi escolhido. Observa-se no diário de campo da professora que após um período de aulas foram escolhidas datas para realizar uma pausa no projeto e compor o portfólio. Nesse momento, dentre suas várias tarefas, os alunos tinham de responder a dois questionários (um de auto-avaliação e outro para avaliação das aulas), cujo objetivo era coletar o maior número de indícios de aprendizagem, de dificuldades e de como estava sendo percebido o que era ensinado.

A auto-avaliação deve ser destacada neste trabalho, pois ajudou os alunos a se localizarem no processo de aprendizagem, analisando o próprio desempenho. As respostas dos alunos coletadas por meio desse procedimento estão expostas no ANEXO $\mathrm{V}$, do qual se segue um recorte organizado em eixos temáticos, relativo às duas pausas realizadas no decorrer da intervenção pedagógica com o portfólio:

\subsubsection{Momentos em que houve dificuldade e a aquisição de conhecimentos}

Foram encontrados os seguintes registros relativos à segunda parada, pergunta 1) Qual atividade realizada Ihe possibilitou aprender novos conhecimentos? Aluna 1 (A.B.): 0 registro (..., porque ele me fez aprender mais coisas dos jogos [Tabela 45].

Aluna 22 (N.C.): Foi na sala eu fiz um cartaz para a pro eu pensava que volear usava instrumentos e ela me explicou que volear é sem instrumento só com as mãos [Tabela 45]. 
$\mathrm{Na}$ segunda parada, foi encontrado o seguinte registro significativo em resposta à pergunta 2) Em qual proposta você teve mais dificuldade?

Aluna 19 (L.): Foi um dia que a nossa classe jogava pega-bandeira e eu sinto dificuldade porque eu não entendia as regras mas então conversei com o grupo e eu entendi [Tabela 45].

5.3.2 A importância da turma em sua aprendizagem e sua participação na aprendizagem da turma

Na primeira parada foram encontrados indícios significativos, relacionados à questão 3) Comente a participação da turma na sua aprendizagem e sua participação na aprendizagem de seus colegas.

Aluna 11 (I.C.): (Participação dos colegas) Um dia a prof. dividiu a classe em 4 partes e também 4 brincadeiras e toda hora trocava de brincadeira. Teve uma hora que 0 meu time teve que jogar barra manteiga e eu não sabia jogar, eles me explicaram direitinho a brincadeira. (Minha participação) Um dia a prof. estava explicando hipóteses de como pode ter surgido os jogos infantis, ela falou que poderia ter vindo da: Europa e Grécia. Eu tenho um livro sobre o Egito que tinha uma parte que falava de brinquedos egípcios antigos, e ninguém imaginava que também pode ter vindo do Egito Antigo!!! [Tabela 43].

\subsubsection{Apontamentos das tarefas que deixou de realizar}

$\mathrm{Na}$ segunda parada foram encontrados indícios significativos relacionados à pergunta 4) O que você deixou de fazer? Por quê? [Tabela 46]:

Aluno 4 (F.): Registros e pesquisas. Pesquisas porque não achei, os registros não dá tempo, faço só às vezes;

Aluna 19 (L.): Eu deixei de fazer pesquisas, porque não tinha tempo, mas agora me organizei.

5.3.4 Pesquisa sobre outros materiais e reconhecimento do que aprendeu com as informações encontradas 
$\mathrm{Na}$ primeira parada foi encontrado o seguinte indício significativo sobre a pergunta 5) Você pesquisou outros materiais para complementar seu portfólio? Aluna 10 (I.C.): Eu coloquei até agora três coisas que é uma pesquisa de onde surgiu os jogos, colei uma peteca de papel e procurei no dicionário o significado de peteca. Eu aprendi que os registros são mais bonitos com alguma coisa diferente [Tabela 44].

$\mathrm{Na}$ segunda parada, a respeito da mesma pergunta foi encontrado este indício:

Aluna 18 (L.): Sim, completaram as informações que tive sobre os diferentes jogos e brincadeiras [Tabela 47].

\subsubsection{Apontamentos dos aspectos que precisam ser melhorados}

Na primeira parada surgiram os seguintes indícios relacionados à pergunta 6) Em que aspectos você ainda precisa melhorar? [Tabela 44]:

Aluno 4 (F.): Lembrar de fazer os registros, volear melhor e um pouco resolver os problemas;

Aluna 19 (L.): Eu preciso melhorar no jogo pega-bandeira e usar materiais para fazer o diário de educação física;

Aluna 22 (N.C.): Eu acho que quando a gente fala no final da aula sobre a aula eu preciso falar mais.

$\mathrm{Na}$ segunda parada, sobre a mesma questão, foram considerados significativos os seguintes indícios [Tabela 47]:

Aluna 22 (N.C.): Pretar mais atenção na aula;

Aluna 1 (A.B.): Eu preciso ainda melhorar a resolver os problemas que fico chamando a professora a toda hora.

Observa-se que os eixos de análise apresentados acima se aproximam daqueles que foram construídos a partir dos dados revelados nos registros diários dos alunos, que estão expostos nas duas primeiras perguntas norteadoras do presente estudo. Entretanto, é relevante considerar que os meios e as circunstâncias em que as representações dos alunos foram registradas nesses dois tipos de avaliação (auto-avaliação e registro diários) apontam respostas com focos diferentes. 
$\mathrm{Na}$ auto-avaliação os alunos refletiram sobre um determinado período de ensino, norteados por questões já formuladas, estabelecendo um olhar distante do processo vivido e praticando a reflexão a fim de sistematizar e recompor as ações realizadas. Nos registros diários a reflexão ocorreu sobre a ação, o que implicou um olhar mais específico e pontual sobre o processo de aprendizagem.

As características do procedimento de auto-avaliação possibilitaram aos alunos revisarem as ações que praticaram em determinado período de ensino, fazer recortes e realizar sínteses sobre o que foi significativo no processo de ensino e aprendizagem.

Foram pontuados, também, pelos alunos aspectos inerentes à postura de estudante, como mostram os indícios a seguir:

Aluna 19 (L.): Usar materiais para fazer o diário de educação física [Tabela 44]; Aluno 4 (F.): Lembrar de fazer os registros [Tabela 44];

Aluna 22 (N.C.): Pretar mais atenção na aula [Tabela 47].

A reflexão sobre as próprias condutas e a compreensão de suas responsabilidades indica a consciência dos alunos sobre os procedimentos necessários para cumprir bem seu papel, o que é um dos objetivos implícitos do projeto proposto. Essa consciência é conseqüência do exercício de auto-observação e autocrítica que, por sua vez, é expressão do processo avaliativo portfólio.

É sabido que nem sempre o professor tem oportunidade e condições de observar a evolução de todos os alunos, porém o procedimento de auto-avaliação na intervenção didática desenvolvida nesta pesquisa apresentou-se como mais um meio para o professor acompanhar a expressão de aprendizagem e as dificuldades dos alunos no processo para fazer as retomadas e intervenções necessárias.

Observa-se nas respostas dos alunos que o procedimento permitiu a elaboração e explicitação de sínteses do conhecimento num determinado período do projeto. Essas sínteses mostram o desenvolvimento da capacidade de sistematização do conhecimento que os alunos registravam diariamente como tarefa de casa, indicando o que de fato consideravam mais representativo no recorte analisado do processo de ensino e aprendizagem.

O processo de reflexão implicado nas questões da auto-avaliação semeou nos alunos a crítica sobre a postura de estudante e favoreceu o reconhecimento dos 
aspectos em que precisavam melhorar e o que poderiam fazer para efetivamente aprenderem.

Para a professora, a aplicação da auto-avaliação, além de se mostrar como mais um meio de acompanhar a aprendizagem dos alunos, contribuiu para a compreensão das representações dos alunos no período analisado, possibilitando reavaliar os métodos e criar novos caminhos para ensinar, promovendo a aprendizagem dos alunos.

5.4 A quarta pergunta norteadora: $O$ portfólio possibilitou à professora reflexão sobre sua prática pedagógica?

Para iniciar a análise e a discussão dos dados referentes à quarta pergunta norteadora, é relevante definir prática pedagógica e estratégia de ensino, em virtude da relação desses termos com o que se pretende investigar.

A prática pedagógica é o trabalho do professor na vida cotidiana escolar, e pode ser caracterizada por ações ou formas escolhidas para ensinar (estratégias de ensino), que correspondem aos objetivos educacionais. As estratégias de ensino, por seu turno, são os caminhos escolhidos ou criados pelo professor, pautando-se numa teoria de ensino para direcionar e facilitar o processo de aprendizagem do aluno.

Observam-se nos registros da professora sinais de diferentes estratégias para ensinar, os quais são percebidos nas declarações expostas no ANEXO VI a seguir:

4b (aula 3): Os jogos escolhidos da pesquisa realizada com os pais motivaram os alunos tanto na aula quanto na produção dos seus registros (prof.);

4c (aula 7): A construção do mapa conceitual possibilitou observar o que os alunos haviam aprendido e revelar o que não ficou muito claro (prof.); 4h (aula 20): As tarefas organizadas em circuito (...) na maioria dos registros (...) foram expressas com detalhes (prof.);

4l (aula 22): Nos registros as discussões realizadas na roda de conversa (...) são sempre mencionadas nos apontamentos dos alunos (prof.);

4m (aula 25): O espaço em que ocorreu essa aula auxiliou a manter os alunos concentrados na proposta (...) possibilitou situações de um auxiliar o outro (prof.). 
As estratégias de ensino que partiram da observação da professora sobre os registros dos alunos, como é apontado nos enunciados $4 \mathrm{~b}$, 4h e $4 \mathrm{l}$, e das notas realizadas sobre as aulas, expostas em $4 \mathrm{c}$ e $4 \mathrm{~m}$, são representativas porque possibilitaram à professora perceber a motivação dos alunos e o modo como eles organizaram o conhecimento, tornando-se eficientes para sua aprendizagem. Os dados revelados nas duas fontes (registros dos alunos e notas de observações das aulas) proporcionaram a identificação de informações que levaram a professora a tomar conhecimento do que estava dando certo em sua prática pedagógica.

Esses indícios se relacionam a um dos objetivos do procedimento de avaliação utilizado, o portfólio, que é aclarado por VILLAS BOAS (2004) ao expor a característica multiproposital desse procedimento. Esse atributo, explica a autora, permite ao professor avaliar o seu trabalho pedagógico por meio das mesmas evidências de aprendizagem usadas para avaliar os alunos.

$\mathrm{Na}$ avaliação das aulas realizada pelos alunos encontram-se vestígios e problemas na prática pedagógica da professora, como podem ser vistos a seguir:

Aluna 11 (I.): Sugere: Mais jogos [Tabela 48] ${ }^{29}$;

Alunos 4 (F.) e 21 (N.C.): Critica: Aulas teóricas (...) [Tabela 48];

Aluna 1 (A.B.): Sugere: Mais aulas práticas [Tabela 49] ${ }^{30}$;

Alunos 1 (A.B.), 3 (C.) e 4 (F.): Critica: As aulas teóricas [Tabela 49].

Observa-se nos indícios expostos acima a manifestação dos alunos sobre a falta de equilíbrio entre as aulas que eram mais reflexivas e as práticas, que acarretou instabilidade e a diminuição do tempo das vivências práticas. Esses indícios demonstram elementos da prática pedagógica da professora que necessitavam ser repensados e aperfeiçoados, pois se percebe a ênfase dada à tomada de consciência e formalização do conhecimento pelos alunos, com diminuição da vivência prática dos jogos, limitando assim a especificidade do trabalho de Educação Física propriamente.

Isso pode ter ocorrido porque o trabalho com portfólio era algo novo e diferente tanto para a professora como para os alunos, o que ocasionou insegurança,

\footnotetext{
${ }^{29}$ Foram encontrados outros indícios com o mesmo direcionamento, que podem ser vistos na Tabela 48, referentes aos alunos 2 (B.), 4 (F.), 12 (J.), 16 (K.), 20 (M.), 21 (N.C.) e 23 (N.).

${ }^{30}$ Outros indícios com o mesmo direcionamento podem ser vistos na Tabela 49 , referentes aos alunos 4 (F.), 8 (G.), 11 (I.), 16 (K.), 17 (L.), 19 (L.) e 21 (N.M.).
} 
com dificuldades iniciais para ambos. Embora a crítica feita pelos alunos com relação ao excesso de aulas reflexivas tenha sido acertada, essa foi a maneira encontrada pela professora para garantir o cumprimento das etapas requeridas para a construção do portfólio e a compreensão desse procedimento avaliativo nunca antes experienciado.

Os mesmos indícios revelam a expressão de um dos entraves a serem vencidos com relação às aulas de Educação Física: a aceitação da aula mais reflexiva por parte dos alunos. Mesmo levando em consideração que pode ter havido excesso na prática da professora quanto a esse tipo de aula, as críticas mostraram uma concepção limitada por parte dos alunos, que consideram a disciplina como constituída apenas de aulas práticas, o que os levou a resistirem à idéia de participar de momentos mais teóricos e produzir os registros para a construção do portfólio.

Essa resistência é influenciada por uma visão que privilegia o ensino de conteúdos procedimentais desenvolvidos por meio de aula práticas, geralmente desprezando o ensino de conteúdos de natureza conceitual e atitudinal, que privilegiam estratégias de aula com características mais reflexivas (BARROS, 2006).

Vale ressaltar que não se está defendendo a substituição da predominância do ensino dos conteúdos procedimentais pelo ensino de conteúdos conceituais e atitudinais. Considera-se que a ampliação de estratégias de aula que utilizem vivências práticas e reflexivas na Educação Física escolar pode favorecer uma aprendizagem mais eficientes para os alunos, uma vez que possibilita a adequação dos diferentes conteúdos às estratégias de ensino e avaliação.

Outro ponto observado na Tabela 48 foi o anseio manifestado por alguns alunos por mais oportunidades de participar nas aulas, indício de mais um problema que a professora precisou rever em seu planejamento de ensino:

Alunos 8 (G.) e 10 (I.C.): Sugere: Os alunos possam escolher os jogos [Tabela 48].

É interessante notar que a solicitação dos alunos para terem mais oportunidade de participação nas aulas é exposta na primeira avaliação a respeito das aulas [Tabela 48], mas não aparece na segunda avaliação [Tabela 49] realizada após um período de aulas. Isso pode ter acontecido porque, ao tomar consciência sobre esse anseio dos alunos, a professora realizou adequações em sua prática 
pedagógica que melhoraram 0 aspecto apontado. Essa observação possibilita compreender que o reconhecimento de problemas na prática pedagógica subsidia a tomada de decisão do professor quanto às práticas que precisam ser aperfeiçoadas no processo de ensino.

Também se observa a importância da avaliação das aulas, realizada pelos alunos, para a professora tomar conhecimento dos pontos positivos de sua prática pedagógica, como mostram os indícios da Tabela 48, em que os alunos elogiam a postura assumida pela professora:

Aluno 3 (C.): Elogia: A motivação da professora;

Aluna 10 (I.C.): Elogia: Atenção e compreensão da professora;

Aluno 16 (K.): Elogia: A professora porque ajuda e é legal.

$\mathrm{Na}$ Tabela 49, novamente os alunos elogiam a postura da professora e as aulas práticas:

Aluna 3 (C.): Elogia: O capricho da professora para preparar aulas diferentes; Aluna 5 (F.): Elogia: Quando a prof. vê, lê e comenta os registros dos alunos; Aluna 21 (N.C.): Elogia: Aulas práticas, as dicas dadas pela professora (...) ${ }^{31}$.

No enunciado 4e [ANEXO VI] a evolução dos alunos é identificada pela professora a partir das informações registradas por eles, como pode ser visto no recorte exposto a seguir:

Nota-se que os alunos têm se empenhado mais na produção dos registros. Considero, de maneira geral, que os fatores que contribuem para isso são: (1) Já se acostumaram a fazer os registros como tarefas de casa; (2) Os critérios de avaliação expostos aos alunos estão mais simplificados e aproximam-se da linguagem deles; (3) Compreenderam que a utilização de outras formas de linguagem diminui o trabalho de estar escrevendo e possibilita a expressão da criatividade; (4) As proposta das aulas práticas mostram-se significativas para os alunos (prof.) [4e, ANEXO VI].

Nesses indícios é possível notar um aspecto relevante do trabalho com portfólio: a facilidade de interpretar e analisar o processo de aprendizagem dos

\footnotetext{
${ }^{31}$ Foram encontrados outros indícios com o mesmo direcionamento, os quais podem ser vistos na Tabela 49, referentes aos alunos 10 (I.C.), 20 (M.), 8 (G.), 15 (J.P.), 17 (L.) e 19 (L.)
} 
alunos, proporcionada pelos registros. No enunciado 4j [ANEXO VI] nota-se até o desenvolvimento das habilidades que os alunos usaram durante o processo, que a professora expõe:

Nessa aula apareceram registros que impressionaram pela organização das idéias expostas. Os alunos relataram as estratégias escolhidas por seu grupo no jogo, as dicas para melhorar e os problemas que enfrentaram com os colegas. Percebe-se que usam com mais tranqüilidade a escrita e o desenho; alguns até se arriscam a utilizar outras formas de registro como cartazes, colagem, pesquisas e maquetes (prof) [4j, ANEXO VI].

No enunciado $4 \mathrm{~g}$ [ANEXO $\mathrm{VI}]$ as considerações da professora nos registros dos alunos é ressaltada, como se observa a seguir:

Percebe-se em alguns registros que o aluno aguarda os meus comentários para ver o que achei da sua produção (prof.).

Esse comentário da professora pode ser entendido como feedback. Segundo MCGOWN, citado por CUNHA (2006), feedback é a informação que se obtém após uma resposta, e é geralmente visto como a mais importante variável que determina a aprendizagem do aluno. Desse modo, entende-se que o feedback pode ser fornecido com o intuito de nortear o aluno em relação a algum aspecto de sua aprendizagem, como resposta a determinada atividade.

No trabalho com portfólio, o fornecimento de retroinformações (feedback) para os alunos é um princípio apontado por VALLE (2002). A autora expõe que o professor deve acompanhar a aprendizagem dos alunos, expondo verbalmente e por escrito, nos registros dos alunos, o que observou em aula. A autora observa que 0 feedback não deve assinalar somente as fragilidades dos alunos; devem pontuar os avanços e os aspectos que precisam ser melhorados, e até sugerir dicas que podem ajudá-los a melhorar as dificuldades encontradas.

De maneira geral, a partir dos indícios relativos à quarta pergunta norteadora o trabalho com portfólio possibilitou compreender o processo avaliativo. Sem se encerrar no levantamento de informações sobre o processo de aprendizagem dos alunos, proporcionou reflexão sobre as ações educativas utilizadas pela professora no contexto de ensino específico, de modo contínuo e processual, designando os pontos positivos e negativos de sua prática pedagógica. 


\subsection{A quinta pergunta norteadora: $O$ portfólio indicou as dificuldades da professora no processo de ensino e aprendizagem?}

Nesta parte do estudo, o objetivo é analisar as percepções da professora sobre o uso do portfólio como procedimento de avaliação, com foco nas dificuldades encontradas.

Os trechos foram recortados a partir das notas de aula e observações da professora sobre os registros dos alunos, apresentados no ANEXO VII. Os indícios apontam as dificuldades da professora no uso do portfólio. Para facilitar a análise, os recortes selecionados foram organizados em quatro eixos, a saber: falta de experiência com o portfólio; necessidade de discutir o trabalho; problemas na prática pedagógica; falta de comprometimento de alguns alunos.

\subsubsection{Falta de experiência com o portfólio}

No enunciado 5e [ANEXO VII], a anotação admito que a insegurança e a falta de maturidade com esse tipo de trabalho me fez conduzir as ações dos alunos sinaliza que, mesmo estando consciente de que a organização dos registros dos alunos no portfólio deveria ser realizada livremente por eles, a professora indicou diretrizes para a organização do trabalho: a ordem dos registros e seus suportes (pasta, papel sulfite).

Considera-se que o medo e a insegurança gerada pela falta de experiência com esse procedimento de avaliação limitaram a possibilidade de o aluno colocar a sua identidade no formato de seu portfólio, devendo seguir uma forma padronizada pela professora. Desse modo, foi desvirtuada uma das particularidades dessa prática citada por vários autores ${ }^{32}$, como a necessidade de delegar responsabilidades aos alunos na avaliação, especificamente no arquivamento e seleção de evidências de aprendizagens e dificuldades recolhidas no processo de ensino e aprendizagem.

\subsubsection{Necessidade de discutir o trabalho}

${ }^{32}$ NASCIMENTO (2006); HERNÁNDEZ (2006) e VILLAS BOAS (2004). 
No enunciado 5h [ANEXO VII] a professora relata a necessidade de dividir suas dúvidas sobre o trabalho com portfólio, como pode ser visto a seguir:

Sinto falta de discutir com alguém da área as estratégias que tenho utilizado na prática do portfólio. Gostaria muito de dividir minhas dúvidas e tomar decisões em conjunto com alguém. Talvez isso diminuísse a minha ansiedade e as atitudes impensadas (prof.).

A solidão pedagógica que a professora revela ter sentido enquanto desenvolvia o trabalho induziu à tomada de decisões imediatistas no processo de ensino e aprendizagem. No estudo de VILLAS BOAS (2004, p.144), com base no depoimento de uma mediadora, é observada a importância de se considerar o trabalho coletivo: "O que garantiu uma maior segurança/autonomia [no trabalho com portfólio] foi a discussão coletiva, o estudo e o processo cotidiano de troca/socialização dos trabalhos [no grupo de estudos]".

\subsubsection{Problemas na prática pedagógica}

Esse eixo de análise está evidenciado em dois indícios extraídos do ANEXO VII:

Enunciado 5b: Percebi que os registros dos alunos são realizados sempre por meio da escrita; poucos usam outros materiais - talvez porque não sabem como fazer isso! Não têm modelos ou referências para fazer diferente (prof.);

Enunciado 5j: Percebi que nos registros que os alunos esquecem de fazer e acabam entregando atrasado poucos são os critérios contemplados (prof.).

Com base no estudo de VILLAS BOAS (2004), entende-se que podem ter faltado na intervenção didática da professora práticas de ensino que incluíssem mecanismos para a inserção de outras linguagens, além da escrita, por parte dos alunos. Na opinião da autora, só assim eles poderão fazer uso de outras linguagens para expressar aprendizagens e dificuldades em seus registros, optando pela via (escrita, desenhada, fotografada, filmada) que considerarem mais fácil. Isso implica entender que não basta o professor solicitar aos alunos que façam uso de diferentes linguagens em seus registros, se eles não passam por vivências variadas para 
manifestar a aprendizagem, a fim de que tenham um referencial para fazer uso dessa estratégia. É o que apontam as seguintes anotações:

Enunciado 5g [ANEXO VII]: Percebo que quando os alunos fazem os registros de maneira incompleta ou, simplesmente não o trazem, isso pode ser conseqüência da forma que as explicações estão sendo apresentadas aos alunos (prof.);

Enunciado 5i [ANEXO VII]: Percebi que os critérios de avaliação fornecidos aos alunos estavam com uma linguagem difícil para os alunos entenderem o que seria avaliado e quais os itens deveriam ter seu portfólio (prof.);

Aluna 18 (L.): Eu não entendi porque os amigos falaram que não pode passar a bola [Tabela 50];

Aluno 23 (N.): Senti dificuldade no jogo floresta porque eu não sabia que no jogo tinha que esperar o pegador falar já [Tabela 52].

Esses indícios apontam insuficiência de informações e/ou inadequação da linguagem nas explicações fornecidas aos alunos. Os alunos sinalizam um problema na prática pedagógica da professora com relação à falta de clareza nas explicações oferecidas a eles nas propostas de aula. Em outra situação a própria professora admite tal dificuldade, como foi mencionado no enunciado 5i [ANEXO VII].

Tais indícios demonstram que os registros inseridos no portfólio dos alunos revelam problemas que poderiam passar despercebidos pela professora.

\subsubsection{Falta de comprometimento de alguns alunos}

Os enunciados $5 f$ (aula 9) e 5j (aula 16) [ANEXO VII] apontam a falta de comprometimento e a resistência dos alunos para produzir os registros nas aulas de Educação Física:

Enunciado $5 f$ [ANEXO VII]: Ao olhar os portfólios, fiquei surpresa ao ver que 15 alunos não haviam entregado (prof. );

Enunciado 5j [ANEXO VII]: Percebi que nos registros que os alunos esquecem de fazer e acabam entregando atrasado poucos são os critérios contemplados (prof.). 
Essa resistência pode estar relacionada ao fato de os alunos estarem inseridos num ritual pedagógico, nas aulas de Educação Física, que normalmente privilegia práticas corporais em detrimento de atividades reflexivas, que exigem predominantemente a reflexão e produção de registros.

Outro ponto que pode ter favorecido a resistência dos alunos à prática dos registros foi fazê-los como tarefa de casa após as aulas de Educação Física. Talvez, se eles tivessem um intervalo para a produção dos registros, por exemplo, realizando um registro a cada três aulas, diminuiria a sobrecarga de tantos registros. Além disso, destaca-se a necessidade de enfatizar as vantagens do portfólio para 0 processo de aprendizagem.

A análise dos indícios sobre as dificuldades da professora evidencia que a experiência inicial com o portfólio trouxe dúvidas e incertezas. Entretanto, a reflexão sobre os problemas favoreceu a compreensão de um novo fazer pedagógico, adotando uma lógica nas propostas de pedagógicas que supere a fragmentação de ensinar segundo certos princípios e a avaliação de acordo com outros.

\subsection{A sexta pergunta norteadora: 0 portfólio possibilitou à professora conhecimento sobre como melhorar as dificuldades relacionadas ao ensino?}

Os indícios que apontam relação com a sexta questão norteadora estão nas observações da professora sobre os registros individuais dos alunos. Essas observações lhe permitiram identificar aspectos da prática pedagógica que podem ser aperfeiçoados, além do conhecimento detalhado das características dos alunos. Após a leitura desses registros foi possível levantar hipóteses sobre como melhorar as ações no ensino, exemplificadas a seguir.

Ao observar o problema da inadequação da linguagem com os alunos, referente aos elementos essenciais que deveriam ser contemplados nos registros, a professora colocou em prática diferentes estratégias, das quais há indícios extraídos de suas anotações de aula:

Enunciado 6a [ANEXO VIII]: A comunicação entre professora e alunos precisava ser melhorada, ou seja, as explicações precisavam ser mais claras e adequadas às características dos alunos. A iniciativa que escolhi para melhorar esse problema 
foi escrever orientações individuais sobre o que precisavam melhorar nos registros inseridos em seu portfólio. Utilizava papeizinhos coloridos que eram grudados nos registros para chamar a atenção dos alunos sobre os critérios que estavam faltando e o que precisavam melhorar (prof.).

Observa-se no enunciado 6a [ANEXO VIII] que a professora passou a focar as dificuldades individuais dos alunos, fornecendo orientações atinentes aos pontos que precisavam aprimorar em seus registros. A mudança de estratégia, passando a orientar os alunos de maneira particular, em vez de fazê-lo por meio de explicações gerais, possibilitou o fornecimento de informações mais claras e específicas sobre 0 que necessitava ser melhorado, facilitando a compreensão dos alunos.

A iniciativa da professora vem ao encontro do que VILLAS BOAS (2004) expõe acerca dos procedimentos necessários para o trabalho com portfólios. A autora afirma que é necessário, quando se inicia um trabalho com portfólios, o professor orientar os alunos sobre os elementos que não estão sendo contemplados. Sugere que o professor atue no sentido de assinalar especificamente o que os alunos devem melhorar, deixando por conta deles solucionar os problemas encontrados.

Enunciado 6b [ANEXO VIII]: Após a exposição dos elementos que os alunos e a professora consideraram que melhoraram e outros que precisavam melhorar, construímos uma lista de itens que poderiam melhorar as dificuldades do grupo (prof.).

Observa-se que o recorte demonstra mais um meio utilizado pela professora para detectar pontos relevantes que auxiliaram no enfrentamento das dificuldades encontradas em sua prática pedagógica. Foram utilizados elementos provindos de suas anotações sobre a aula e das observações dos alunos, para construir coletivamente (professora e alunos) uma lista de elementos que os alunos poderiam levar em conta para melhorar as dificuldades expostas. Considera-se que isso possibilitou à professora compreender de outra maneira o ensino, promovendo um processo de avaliação mais transparente e democrático.

No enunciado 6c [ANEXO VIII] a professora coloca em prática outra estratégia para minimizar a falta de clareza das instruções para a produção do registro, como fica evidente abaixo: 
Percebi que os critérios de avaliação fornecidos aos alunos estavam com uma linguagem difícil para eles entenderem o que seria avaliado nos registros inseridos no portfólio. A estratégia utilizada para melhorar esse problema foi procurar outra maneira fornecer os critérios por meio de perguntas que os alunos pudessem responder, construindo seu registro de forma mais completa. Tive a idéia de construir essas perguntas atrelando-as ao objetivo que tinha para atingir como empreendimento final no projeto, que se relaciona à construção de um livro de jogos para presentear a um amigo. Deste modo, as perguntas ficaram da seguinte maneira:

1- Como você ensinaria a um amigo o jogo...?

2- Quando você e seus amigos estavam jogando..., você sentiu alguma dificuldade?

3- Qual foi essa dificuldade?

4- O que você fez, ou é possível ser feito, para melhorar a dificuldade?

5- Durante o jogo... aconteceu algum problema e de que forma você e o grupo resolveram? [6c, ANEXO VIII].

Observa-se que a professora valoriza o formato de perguntas relacionadas ao empreendimento final do projeto, a construção de um livro de jogos: em vez de perguntar "o que você aprendeu nesse jogo?", questiona "como você ensinaria esse jogo para um amigo que quer jogar com você"?

A preocupação de dar sentido às informações que utilizava com os alunos reforçou o empreendimento final do projeto - livro - e sua relação com as perguntas que funcionaram como roteiro de temas a serem contemplados. Assim, os alunos perceberam o uso que seria dado às informações que registraram:

Enunciado 6d [ANEXO VIII]: Após os alunos lerem meus apontamentos em seu registro, a estratégia escolhida foi fazer coletivamente esse registro, contemplando os critérios combinados na aula e eu atuando como escriba. A intenção era fornecer aos alunos sugestões sobre como fazer um registro de forma escrita, desenhada e com colagem de figuras pesquisadas em livros e revistas (prof.).

Percebe-se no enunciado 6d [ANEXO VIII] mais uma estratégia adotada pela professora para materializar as instruções e as orientações emitidas na produção dos 
registros, o que é observado também no apontamento da aluna 1 (A.B.): Fazer 0 registro de maneira coletiva foi bom para quem tinha dúvidas [Tabela 53].

NASCIMENTO (2006) e VILLAS BOAS (2004) assinalam em seus estudos sobre o portfólio que essa estratégia é necessária para que os alunos possam partir de referências concretas que os norteiem a respeito das características de um registro considerado adequado. Esse procedimento pode ajudar os alunos na análise do seu próprio trabalho.

A estratégia de envolver os alunos em discussões e registro coletivos também é sinalizada em:

Enunciado 6e [ANEXO VIII]: Percebi que nos registros que os alunos esquecem de fazer e acabam entregando atrasado poucos são os critérios contemplados. Pergunto-me o que preciso fazer para melhorar essa situação. Resolvi retomar a discussão com os alunos: Por que é importante registrar? Três pontos foram levantados pelos próprios alunos:

1) para saber e lembrar o que aprende ou não;

2) para melhorar aquilo em que sentiu dificuldade;

3) para ajudar a professora a avaliar o que deu certo ou errado na aula (prof.).

A partir dos recortes discutidos acima, foi possível identificar os procedimentos adotados pela professora (orientações individuais, registro a partir de um modelo, registros coletivos e valorização do produto final) no enfrentamento das dificuldades com relação ao ensino, possibilitando conhecimento sobre como melhorar as dificuldades.

\section{CONSIDERAÇÕES FINAIS}

Ao propor um trabalho que discutisse a avaliação em Educação Física escolar, não procurei solucionar a questão, e sim compreender com mais profundidade 0 tema e mostrar o caminho que encontrei para pôr em prática a avaliação de maneira mais adequada ao contexto escolar.

O estudo se iniciou com a busca de explicações sobre 0 ato de avaliar, distinguindo dois significados: um que se relaciona com a idéia de medir a aprendizagem dos alunos, tendo como foco os resultados atingidos no final de um 
programa de ensino, e outro que inclui a atribuição de valor, ou seja, a apreciação, no decorrer do processo de ensino e aprendizagem, dos resultados atingidos ou não pelos alunos, tendo em vista a aferição da qualidade desses resultados.

Considerando os dois significados do termo avaliar, o que se refere à valoração da aprendizagem dos alunos aponta aspectos mais adequados ao contexto escolar, pois suscita a necessidade de apreciar e acompanhar o que os alunos aprendem, por meio de noções teóricas e dificuldades manifestadas empiricamente. No entanto, percebeu-se que a definição que pondera a avaliação como medida e determinação numérica da aprendizagem dos alunos é o modo mais freqüente de os professores entenderem e praticarem a avaliação na escola.

Essa forma de compreender a avaliação corrobora uma visão meramente classificatória e seus diversos mecanismos de eliminação, que trazem como conseqüência para a grande massa de alunos que ingressam na escola a nãoobtenção de sucesso escolar, acabando por ficar à margem do processo. Essa situação escolar é formalmente legitimada pelas notas e, informalmente, pelos julgamentos e valores que se constroem no ambiente escolar, os quais acabam limitando as possibilidades futuras dos alunos.

No Brasil, autores como LUCKESI (2005), VASCONCELOS (2003) e SOUZA (2005) denunciam os problemas das práticas avaliativas que seguem a perspectiva de somente medir os resultados de aprendizagem. Segundo os autores, as propostas de avaliação dos professores geralmente se amparam em proposições não-críticas de ensino e aprendizagem, com a busca de reprodução e verificação do conhecimento ensinado, além de, às vezes, a avaliação atender a outros fins, como garantir o poder do professor perante os alunos, ser um meio para controlar a disciplina dos alunos ou, ainda, uma forma de obter um registro que assegure o passaporte para a próxima série.

Observou-se que as discussões e proposições que se contrapõem a essa postura da avaliação como medida e como instrumento de poder do professor se fortaleceram com os estudos publicados em meados da década de 90 .

Foi a partir daí que se pôde observar, nos trabalhos de PERRENOUD (1999), ZABALA (1994) e HADJI (1994), a definição da avaliação formativa como a mais coerente para avaliar o processo de ensino e aprendizagem dos alunos. Dentre seus 
vários pressupostos, a avaliação formativa enfatiza a importância de avaliar com foco no processo seguido pelos alunos, e não só no resultado atingido, a fim de possibilitar que eles participem do processo de avaliação, refletindo sobre seu progresso. Apóia-se no princípio de que a avaliação, o ensino e a aprendizagem são interdependentes. Assim, as atividades avaliativas não devem acontecer de maneira desconectada do processo de ensino e aprendizagem, nem apoiar-se no ponto de vista de aprender para esquecer. Elas devem considerar o processo seguido e resgatar as aprendizagens dos alunos.

Segundo VASCONCELOS (2003) e PERRENOUD (1999), a avaliação formativa não está presente na prática pedagógica dos professores. Não há vinculação entre o que os professores dizem a respeito da avaliação e o que realmente colocam em prática. Eles vivem entre duas lógicas: a perspectiva da avaliação formativa no discurso e a tradicional na prática, o que decorre da falta de clareza conceitual sobre o processo de avaliação, conseqüência de formação insuficiente sobre $o$ assunto.

Os mesmos autores recomendam que, no tocante à formação dos professores a respeito da avaliação, sejam recolocadas questões básicas para discussão, tais como: para que, como e para quem se está avaliando. Essas questões parecem ser um ponto promissor para se discutir a prática pedagógica, buscando construir uma nova visão de avaliação, que estabeleça novas relações com o conhecimento no processo de ensino e aprendizagem. Com isso, compreende-se que a proposta dos autores aponta uma postura crítico-reflexiva do professor diante do trabalho que realiza e também o resgate da importância do projeto pedagógico da escola, visto como espaço de produção coletiva.

Neste estudo, a avaliação formativa foi considerada a perspectiva de avaliação mais adequada para ser seguida na pesquisa de campo, pois ela tem características com valor pedagógico respeitável para o desenvolvimento do processo de ensino, aprendizagem e avaliação dos alunos nas aulas de Educação Física.

De maneira geral, os vestígios históricos no contexto da Educação possibilitaram observar que não é só na área da Educação Física que se encontram dificuldades para avaliar de maneira apropriada. Em outras áreas do ensino há problemas com relação à compreensão e prática da avaliação, e conseqüentemente 
ao processo de ensino e aprendizagem. Ao mesmo tempo, a revisão da literatura possibilitou entender os caminhos pelos quais os professores construíram seus procedimentos de avaliação.

Procurei compreender também a avaliação da aprendizagem, especificamente na Educação Física escolar, enfrentando como dificuldade principal o escasso número de publicações na área que abordassem esse tema, além de propostas concretas de avaliação.

$\mathrm{Na}$ análise dos vestígios históricos da Educação Física escolar percebeu-se que a avaliação seguiu o mesmo caminho percorrido nas demais áreas da Educação, no que diz respeito à priorização dos testes e das tabelas de quantificação pautados em padrões ideais de movimento e capacidades físicas.

A mudança dessa visão teve início em meados da década de 80 , até a década de 90, quando foi questionada essa perspectiva de avaliação e as discussões na área voltaram-se para a ampliação do quadro de apontamentos teóricos que assimilavam os aportes das ciências sociais e humanas.

As escassas propostas de avaliação publicadas nos livros e periódicos da área apresentaram algumas proposições a respeito da visão de avaliação na Educação Física escolar. Tais especulações possibilitaram para o presente estudo a assimilação de alguns aspectos que auxiliaram na construção de um conceito de avaliação para a área. Sinteticamente, os aspectos mais expressivos versam sobre o entendimento de que a avaliação deve abarcar a reflexão da prática de aula e, portanto, o processo de ensino e de aprendizagem. Ela deve considerar que cada aluno possui um ritmo de trabalho diferente e que não se pode avaliar com intenções voltadas à punição, mas deve-se ter como objetivo acompanhar e auxiliar o processo de aprendizagem. A nota deve ser considerada como um símbolo que sintetiza o processo de aprendizagem do aluno, que deve participar e obter os esclarecimentos necessários sobre a atribuição da nota. A avaliação deve auxiliar o professor e os alunos na obtenção de resultados, na identificação de falhas durante o processo de ensino e aprendizagem e na indicação dos acertos.

No entanto, as pesquisas sobre como o professor de Educação Física entende e coloca em prática a avaliação apontam a utilização de procedimentos e intenções distantes das proposições citadas acima. 
As pesquisas assinalaram que a avaliação em Educação Física escolar é realizada pelos professores de forma acrítica e sem reflexão. Os resultados das pesquisas revelam que os professores alegam que seu processo de formação não incluiu discussões, apresentação de propostas e oportunidades de aplicação de processos avaliação diferenciados.

Desse modo, foi possível observar que os professores avaliam para atender a fins burocráticos. A improvisação e a ausência de compromisso com a avaliação são demonstradas nas aulas de Educação Física. A falta de comprometimento em transformar essa realidade ocorre porque os professores desconhecem outro modo de fazer e acabam reproduzindo o processo de avaliação que tiveram em sua formação.

Considera-se que existe carência de mais discussões e reflexões em torno da prática educativa do professor de Educação Física, por isso as deficiências observadas com relação à prática da avaliação da aprendizagem se sobressaem. Entende-se que essas dificuldades podem ser melhoradas com a promoção de situações de formação continuada, bem como nos próprios cursos de licenciatura.

As propostas de formação para os professores devem sensibilizá-los para se atualizarem sobre as concepções de ensino, aprendizagem e avaliação para que ocorram de maneira integrada, gerando no professor um envolvimento crítico para repensar autonomamente sua postura pedagógica. Para a reelaboração de seu fazer profissional, em especial a ação avaliativa gerada pelo ponto de vista crítico-reflexivo, o professor precisa ser estimulado a colocar em prática a teoria estudada e apresentar em grupos de estudos e de formação continuada os resultados atingidos em seu contexto de trabalho.

Encontraram-se na proposta do portfólio subsídios teóricos que poderiam facilitar o estabelecimento de mudanças na prática avaliativa dos professores em geral, e por isso optou-se por aplicá-lo na prática, como é apresentado no trabalho de campo.

O trabalho de campo mostrou, a princípio, a teoria entrando em conflito com a prática pedagógica e desencadeando transformações. Minhas leituras sobre avaliação da aprendizagem e sobre o portfólio impulsionaram a revisão da prática pedagógica e de minhas concepções sobre o assunto. Essa revisão baseou-se na 
comparação de minhas práticas e concepções com as descritas pela literatura sobre o ensino, a aprendizagem e a avaliação, uma vez que as dificuldades que eu enfrentava poderiam ser superadas a partir de mudanças nas concepções e práticas.

A partir do momento em que tive minhas concepções e práticas problematizadas por essas leituras, senti-me inclinada a experienciar, em aula, uma nova prática, baseada na teoria do portfólio. Entretanto, não fiz isso como quem segue uma receita. Ao contrário, procurei inspiração nesses pressupostos, fazendo adaptações às condições de minha prática. Essa mudança não ocorreu de uma hora para outra. Minha história escolar, minha formação inicial e minha experiência docente não podiam ser simplesmente negadas ou abandonadas a partir de teorias e experiências de outros. Foi preciso que eu mesma experienciasse essa nova proposta de avaliação e refletisse sistematicamente sobre ela.

Durante esse processo, foram fundamentais a mediação de alguns amigos da área, de meu orientador e a investigação sobre minha prática. Tudo isso contribuiu para que eu ressignificasse a teoria e a prática da avaliação em minhas aulas, apropriando-me, assim, efetivamente, dela e produzindo novos saberes docente. Em meio a todo esse processo, fui reconfigurando, aos poucos, minha prática pedagógica. Identifiquei, então, os primeiros problemas e dificuldades: o fornecimento de informações pouco claras para os alunos, a falta de planejamento para garantir equilíbrio na quantidade de aulas com características mais reflexivas e práticas, a necessidade de exercitar o olhar apurado sobre os vestígios de aprendizagem e de dificuldades deixados pelos alunos em seus registros.

A partir disso, observei mudanças em minha prática pedagógica, como propostas mais abertas aos alunos, desafiando-os a se auto-avaliarem e participarem mais das aulas, atuando como sujeitos da própria aprendizagem. Em outras palavras, o trabalho me motivou a buscar novas idéias, aperfeiçoar o ensino que ministrava e melhorar o processo de aprendizagem dos alunos. Com esses dados, notei em mim o movimento de compreender meus problemas e dificuldades, e entender as idéias dos alunos, arbitrando conflitos, valorizando e dinamizando as interações professor-aluno e aluno-aluno.

A organização e a análise das informações deste estudo pelo paradigma indiciário possibilitaram uma nova forma de me observar como professora e de 
perceber a realidade do contexto escolar que eu vivia com os alunos, uma vez que 0 método pondera a busca por sinais, indícios que permitam decifrar o que aconteceu no âmbito da microanálise do objeto pesquisado, como ocorreu neste estudo - a experiência com o portfólio.

O processo de reflexão sobre minha prática, quando da produção do diário de campo, das observações sobre os registros dos alunos, do processo de seleção, interpretação e análise dos indícios, fez com que eu lançasse sobre a prática pedagógica um olhar crítico, inscrito no tempo de trabalho como uma rotina e como um estado de alerta permanente: antes, no decorrer da ação de ensinar e a posteriori.

Frente a tudo isso, identifico o maior desafio enfrentado neste estudo: o distanciamento da própria prática pedagógica no momento da análise, para conseguir o "estranhamento" necessário entre o professor-pesquisador e sua prática pedagógica.

O fato de ser pesquisadora, também sujeito da pesquisa e ter como objeto de pesquisa a própria prática pedagógica, fez com que eu - professora-pesquisadora mantivesse, com a realização do trabalho de pesquisa e de aula, uma relação pessoal e emocional mais intensa do que comumente se observa, com reflexos em minha atividade docente. Entretanto, alguns fatores me auxiliaram a estabelecer com minha prática pedagógica um nível de "distanciamento" e "estranhamento" adequados. Entre outros, destaco:

- a busca de indícios, baseada não somente em minha memória, mas também no diário de campo, nas gravações em áudio, nos registros inseridos nos portfólios dos alunos, visando a aliar a fidelidade dos fatos à sua subjetividade;

- o olhar externo do orientador, que trouxe novas interpretações, dando origem à produção de outras análises sobre minhas experiências com o portfólio;

- a leitura crítica e a discussão deste trabalho de pesquisa pela Banca Examinadora do Exame de Qualificação, que me ajudou a deslocar minhas análises, a princípio situadas em um nível simplista que ponderava apenas a avaliação, de forma a estabelecer um diálogo mais ampliado, considerando o 
portfólio não só como um procedimento de avaliação, mas uma forma de intervenção didática.

Percebi que a experiência em aula com o portfólio me possibilitou ampliar e aprofundar minha compreensão sobre o que vem a ser o portfólio e seu papel no ensino e na aprendizagem de professores e alunos. À primeira vista, o portfólio pode ser entendido apenas como mais uma alternativa didática de avaliação formativa da aprendizagem dos alunos. Entretanto, uma análise mais cuidadosa dessa experiência, como a que foi realizada neste estudo, revela outras potencialidades pedagógicas, tais como: (a) a possibilidade do exercício da autonomia, participação e cooperação entre o professor e os alunos; (b) uma nova visão não só do ato de avaliar, mas também do processo articulado que envolve o ensino, a aprendizagem e a avaliação dos alunos; (c) uma outra maneira de o professor e os alunos perceberem os avanços e as dificuldades, pois propõe a reflexão sobre a ação em conjunto; (d) a busca por novos caminhos que ajudem a superar os problemas e construir metas a serem atingidas; (e) o conhecimento do que foi mais significativo para os alunos no programa de ensino; (f) a necessidade de intervenções do professor para que os alunos conheçam os critérios de produção dos registros e para que seja garantida a produção de registros de conhecimento, utilizando-se a reflexão e mantendo a coerência com o que foi proposto e combinado em aula; (g) possibilidade de o professor observar o que os alunos aprendem por meio de diferentes registros que revelam as características individuais de aprendizagem, podendo utilizar esse conhecimento para a formulação de intervenções individualizadas. Em síntese, é um procedimento que modifica a visão de aluno passivo que reproduz os conhecimentos transmitidos pelo professor, pois a essência da proposta é fazer com que o aluno se torne agente do próprio aprendizado e tenha, assim como o professor, responsabilidades a serem cumpridas.

Contudo, é importante fazer referência às habilidades e competências necessárias ao professor para que possa planejar e mediar situações de ensino e aprendizagem baseadas nos pressupostos do portfólio. Como vimos neste trabalho, as habilidades e competências necessárias para formular intervenções que auxiliassem os alunos na avaliação do que aprenderam ou não nas aulas desenvolveram-se à medida que aprofundei e ampliei minha compreensão sobre as 
concepções de ensino, aprendizagem e avaliação e o papel educativo da proposta do portfólio. Esse conhecimento levou à aprendizagem de competências e habilidades que consistiram em selecionar conteúdos e situações de ensino propícias, explicitar as intenções do trabalho, formular orientações claras que auxiliassem os alunos nas tarefas solicitadas, elaborar tarefas que considerassem 0 conhecimento prévio dos alunos e os novos conhecimentos que poderiam estar envolvidos, para produzir novos significados.

Ao observar essas habilidades e competências que o portfólio solicitou, compreende-se que tal procedimento não é só um modo de avaliação, mas também uma forma de intervenção didática que cumpre a função de ensinar, aprender e avaliar, o que depende de um programa ou projeto de ensino estruturado para que seja colocado em prática de maneira efetiva.

A gestão da prática do portfólio em aulas de Educação Física ainda foi, para mim, um grande desafio, assim como foi para os alunos. A realização dos registros sobre o que aprenderam ou não em aula (solicitados como tarefa de casa) e a proposta de aulas reflexivas levaram a situações que conflitavam com a tradição pedagógica, ameaçando os modelos de escola, de aula, de professor e de aluno trazidos por alguns participantes (alunos). Esses problemas foram superados com 0 processo de conquista e sedução dos alunos, por meio de estratégias como o diálogo e aclarações constantes acerca dos objetivos do trabalho e da relevância das tarefas solicitadas para melhorar o processo de aprendizagem.

É válido ressaltar a possibilidade que a aplicação do portfólio trouxe para os alunos, que aprenderam a reconhecer seus avanços, bem como as dificuldades que enfrentavam no processo de ensino e aprendizagem. Esse reconhecimento subsidiou o processo de reformulação de estratégias para aprender, à medida que os alunos explicitavam o que fizeram ou poderiam fazer para melhorar. Isso certamente favoreceu a sistematização de novas modalidades de solução de problemas e validou aspectos relevantes da postura de estudante, como a disponibilidade para refletir e a busca de novos recursos para aprender.

De maneira geral, com relação à incorporação do portfólio nas aulas de Educação Física no currículo, foi possível entender que ele exige do professor a adequação do conteúdo, seu nível de conhecimento sobre o conteúdo, possibilite o 
envolvimento dos alunos com o conteúdo, ofereça tempo disponível para selecionar os registros e a produção das reflexões sobre eles. Mas o essencial é não tratar o portfólio como uma tarefa extra, ou seja, uma atribuição a mais para o professor e uma atividade a mais para o aluno. Isso para que ele não se transforme num "peso". Importante é incorporá-lo às atividades propostas em aula, para que se possa usufruir de forma crescente de seu potencial pedagógico.

Todavia, como não poderia deixar de mencionar, para trabalhar com portfólio é fundamental a formação adequada dos professores. Essa formação deve pautar-se na reformulação de conceitos e na integração de ensino, aprendizagem e avaliação. Também é necessária a criação de condições dentro das escolas públicas e privadas para o professor implementar a proposta com turmas menos numerosas e número de aulas reduzido, a fim de que o professor tenha tempo para planejar as atividades e avaliar os alunos, além de também participar de grupos de estudo para trocar experiências. Com carga horária completa e sem a formação que contemple os pressupostos do portfólio, considera-se impossível trabalhar com esse procedimento de avaliação.

Além dessas preconizações, mesmo o professor não dispondo de tais condições, entende-se que a proposta do portfólio como possibilidade de intervenção didática pode ser adaptada a cada contexto. A forma como será construído pode ser mais simplificada do que a apresentada neste estudo, por exemplo, com a produção dos registros sendo realizada pelos alunos como tarefa de casa, de maneira individual, em duplas, em grupo; pode, ainda, ser solicitado um registro a cada três ou quatro aulas. Os registros podem ser construídos coletivamente em sala, com a professora atuando como escriba, ou podem ser estabelecidas parcerias com 0 professor polivalente, possibilitando, assim, a prática dos registros em sala em outro horário que não o da aula de Educação Física.

Por meio deste estudo foi possível compreender que para o professor de Educação Física conseguir mudar suas concepções sobre o processo de avaliação é necessário, primeiramente, entender que a avaliação não é uma norma burocrática que se encerra com a prática da observação e atribuição da nota no fim do bimestre. A avaliação faz parte do processo de construção de conhecimento dos alunos, portanto não deve ser realizada de maneira desconectada do processo de ensino e 
aprendizagem e também deve ser um meio para o professor analisar se os objetivos educacionais foram atingidos ou não, bem como repensar sua prática para que esses objetivos possam ser atingidos.

Assim sendo, para a realização de uma avaliação clara e coerente com os objetivos educacionais, é importante buscar um ensino com mais qualidade. Contudo, o professor necessita de base teórica consistente e bem definida para realizar um processo de avaliação mais apropriado e justo com seus alunos.

Para isso, considera-se imprescindível que as discussões, os estudos e as publicações a respeito desse tema sejam mais enfáticos com relação à necessidade de um corpo de conhecimento sólido em avaliação da aprendizagem na Educação Física escolar, pois serão esses estudos que poderão contribuir para o processo de formação dos professores que atuam nas escolas. Ao mesmo tempo, torna-se necessária a criação de condições para que esse processo de formação aconteça dentro do contexto em que o professor trabalha.

Para finalizar, acredita-se que o papel de desvelamento proposto neste estudo foi cumprido; resta a continuidade por meio de discussões, reflexões e novas aplicações do portfólio em aulas de Educação Física para continuar a caminhar e se apropriar de novas indagações e recursos encontrados para a adaptação e aplicação do mesmo. Assim, este trabalho não é o fim, mas talvez o começo de uma diferente caminhada na Educação Física escolar. 


\section{REFERÊNCIAS BIBLIOGRÁFICAS}

AMANDIO, A. C. Diretrizes para normas de dissertação e teses. SP: EEFEUSP, 2000.

ALMEIDA JÚNIOR, V.P. $O$ processo de formação das políticas de avaliação da educação superior no Brasil (1983-1996). 2004. 144f. Tese (Doutorado em Pedagogia) - Faculdade de Educação, Unicamp, Campinas.

AROEIRA, K.P.; RODRIGUES, F. Avaliação escolar: uma análise da fala de professores de educação física da rede municipal de Vila Velha - ES. Revista Brasileira de Educação Física e Esporte, São Paulo, v.20, n.5, set., p.375, 2006.

AZANHA, J.M.P. Uma digressão quase-metodológica. Cadernos de História e Filosofia da Educação, São Paulo, v.5, n.7, p.117- 149, 2002.

BARROS, A. M. de. A prática pedagógica dos professores de educação física e o tratamento da dimensão conceitual dos conteúdos. 2006. 47f. Dissertação (Mestrado em Pedagogia da Motricidade Humana) - Instituto de Biociências do Campus de Rio Claro, Universidade Estadual Paulista, Rio Claro.

BETTI, M. Educação física e sociedade. São Paulo: Ed. Movimento, 1991.

Valores e finalidades na educação física escolar: uma concepção sistêmica. Revista Brasileira de Ciências do Esporte, Santa Maria, v.16, n.1, p.14-21, 1994.

BOGDAN, R.; BIKLEN, S. Investigação qualitativa em educação. Porto: Porto Editora, 1994.

BRASIL, Ministério da Educação e do Desporto. Secretaria de Educação Fundamental. Parâmetros Curriculares Nacionais para o Ensino Fundamental. Brasília: MEC, 1997.

CARIA, T.H. Experiência etnográfica em ciências sociais. Lisboa: Ed. Afrontamentos, 2002. 
CAMARGO, A.L.C. O discurso sobre a avaliação escolar do ponto de vista do aluno. Revista da Faculdade de Educação, São Paulo, v.23, n.12, jan/dez, 1997.

COLL, C., MARTíN, E. A avaliação da aprendizagem no currículo escolar: uma perspectiva construtivista. In: COLL, C. et al. O construtivismo na sala de aula. São Paulo: Ática, 1998.

CUNHA, F. A. Feedback como instrumento pedagógico em aulas de educação física. Revista Digital. Buenos Aires, ano 9, n. 66, p.1-9, 2003.

Disponível em: www.efdeportes.com. Acesso em 30/11/2006.

DARIDO, S.C. A avaliação em educação física escolar: das abordagens à prática pedagógica. Anais do V Seminário de Educação Física Escolar: Avaliação em Educação Física Escolar. São Paulo, Universidade de São Paulo, p.50-60, 1999.

DEMO, P. Avaliação qualitativa. Campinas: Autores Associados, 2005.

ESTEBAN, M.T. O diálogo como conteúdo e método de investigação na escola. Disponível em: <www.educacaoonline.prof.br $>$. Acesso em: 23/11/2002.

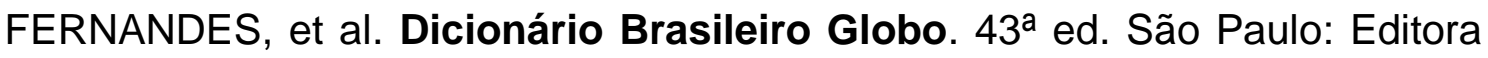
Globo, 1996.

FERRAZ, O.L. Referenciais curriculares da Fundação Bradesco: educação física. São Paulo, 2004.

FERRAZ, O.L.; FLORES, K.Z. Educação física na educação infantil: influência de um programa na aprendizagem e desenvolvimento de conteúdos conceituais e procedimentais. Revista Paulista de Educação Física, São Paulo, v.18, n.1, p.47-60, 2004.

FRANCO, M.A.S. Pedagogia da pesquisa-ação. Educação e Pesquisa, São Paulo, v.31, n.3, set/dez, p.483-502, 2005.

FRANCO, M.L.P.B. Pressupostos epistemológicos da avaliação educacional. In: SOUZA, C.P. de. Avaliação do rendimento escolar. Campinas: Papirus, 2005.

FREIRE, J. B. Educação de corpo inteiro. São Paulo: Ed. Summus, 1998. 
.; SCAGLA A.J. Educação como prática corporal. São Paulo: Scipione, 2004.

GINZBURG, C. Mitos, emblemas e sinais. São Paulo: Companhia das Letras, 1989.

GÓMEZ, F.; JIMENEZ, L. Metodologia de la investigación cualitativa. Málaga: Ediciones Aljibe, 1999.

GHIRALDELLI JR., Paulo O que é pedagogia? 3. ed. São Paulo: Brasilense, 1997.

HADJI, Charles. Avaliação regras do jogo. Porto: Porto Editora, 1994.

Avaliação desmistificada. Trad. Patrícia Ramos. Porto Alegre: Artes Médicas, 2001.

HERNÁNDEZ, F. Transgressão e mudança na educação: projetos de trabalho. Porto Alegre: Artmed, 1998.

Cultura visual, mudança educativa e projetos de trabalho. Porto Alegre: Artmed, 2000.

HOFFMANN, J.M.L. Avaliação mediadora: uma prática e construção, da pré-escola à universidade. Porto Alegre: Mediação, 1993.

KINCHIN, G.D. Using team portfolios in a sport education season. JOPERD, Reston, v.72, n.2, February, p. 42- 45, 2001.

KIRK, M.F. Using portfolios to enhance student learning and assessment. JOPERD, Reston, v.68, n.7, September, p.29-33, 1997.

KRAEMER, M.E.P. Avaliação da aprendizagem como processo construtivo de um novo fazer. Disponível em: $<$ www.gestiopolis.com/canales4/ger/avaliacao.htm>. Acessado em: 14/6/2006. 
LE BOULCH, J. Educação psicomotora. Porto Alegre: Artes Médicas, 1986.

LIMA, A. de O. Avaliação escolar: julgamento ou construção? 9. ed. Rio de Janeiro: Ed.Vozes, 1994.

LUCKESI, C.C. Filosofia da educação. São Paulo: Cortez, 1994.

Avaliação da aprendizagem escolar: estudos e proposições. 16. ed. São Paulo: Cortez, 2005.

MACEDO, L. de. Ensaios pedagógicos: como construir uma escola para todos? Porto Alegre: ARTMED, 2005.

MACHADO, N. J. Avaliação educacional: das técnicas aos valores. São Paulo: IEA-USP, 1993.

Matemática e educação: alegorias, tecnologias e temas afins. São Paulo: Cortez, 2002.

MATOS, J.; NUNES, M. Projeto Brasil urgente: A igreja e a colonização. Disponível em: <http://www.expo500anos.com.br/painel 33.htm>. Acesso em: 26/9/2006.

MARTIN-KNIEP, G.O. Portafólios del desempeño de maestros, profesores y diretivos: la sabiduría de la práctica. Buenos Aires: Paidós, 2001.

MARTINS, J.; BICUDO, M. A. V. A pesquisa qualitativa em psicologia. São Paulo: Educ, 1989.

MAUD, J.M. Avaliação em educação física escolar: um relato de experiência. 2003. 69f. Dissertação (Mestrado em Educação Física escolar) Faculdade de Educação Física, Unicamp, Campinas.

MELOGRANO, V.J. Designing the physical education curriculum. Champaign, Human Kinetics, 1996.

NASCIMENTO, P.N.C. O uso do portfólio no processo de avaliação. In: POGRÉ, P.; Equipe do Colégio Sidarta. $O$ ensino para compreensão. Vila Velha (ES): Ed. Hoper, 2006.

NOGUEROL, A. Aprender na escola: técnicas de estudo e aprendizagem. Porto Alegre: Artmed, 1999. 
OHLWEILER, Z.N.C. Avaliação da aprendizagem no currículo de educação física nas escolas de Santa Cruz do Sul. 1992. 180f. Dissertação (Mestrado em Ciência do Movimento Humano) - Universidade Federal de Santa Maria, Santa Maria.

OLIVEIRA, J.G.M.de. Educação Física escolar: construindo castelo de areia. Revista Paulista de Educação Física, São Paulo, v.5, n.1/2, p.5-11, 1991.

PERRENOUD, P. Avaliação: da excelência à regulação das aprendizagens entre duas lógicas. Porto Alegre: Artes Médicas, 1999.

POZO. J. I. Aprendizes e Mestres. Porto Alegre: Artmed, 2002.

Teorias cognitivas da aprendizagem. 3. ed. Porto Alegre: Artes Médicas, 1998.

A aprendizagem e o ensino de fatos e conceitos. In: COLL et al. Os conteúdos na reforma: ensino e aprendizagem de conceitos, procedimentos e atitudes. Porto Alegre: Artes Médicas, 2000.

RANGEL, J.N. O portfólio e a avaliação no ensino superior. Estudos em Avaliação Educacional, n.28, jul-dez, p.151-157, 2003.

RODRIGUES, G.M. A avaliação na educação física escolar: caminhos e contextos. Revista Mackenzie de Educação Física e Esporte. Barueri, ano 2, n.2, 2003.

ROMÃO, J.E. Avaliação dialógica: desafios e perspectivas. São Paulo: Instituto Paulo Freire, 1998.

ROMBALDI, R.M. de. A formação profissional em educação física e o ensino da avaliação. 1996. 144f. Dissertação (Mestrado em Ciência do Movimento HUmano) - Universidade Federal de Santa Maria, Santa Maria. 
RÚBIO, Kátia. Métodos qualitativos - uma visão sob a óptica da ética. Texto apresentado no II Seminário de Ética em Pesquisa com Seres Humanos. São Paulo, EEFEUSP, 2006.

SANTOS, C. R. dos. Avaliação educacional: análises conceituais, legal e crítica. São Paulo: Editora Avercamp, 2005.

SANTOS, W. Avaliação na educação física escolar: o debate acadêmico em periódicos. Disponível em: <www.proteoria.org>. Acesso em: $17 / 7 / 2006$.

SAUL, A.M. Avaliação educacional. Disponível em: $<$ http://www.crmariocovas.sp.gov.br/pdf/ideias 22 p061-068 c.pdf $>$. Acesso em: 17/7/2006.

SIERRA, B.; CARRETERO, M. Aprendizagem, memória e processamento da informação: a psicologia cognitiva da instrução. In: COLL, C.; PALACIOS; MARCHESI, A. Desenvolvimento psicológico e educação: psicologia da educação. Vol. 2. Porto Alegre: Artes Médicas, 1996.

SILVA, J. F. da. Avaliação e aprendizagens significativas. Texto apresentado no programa Salto para o Futuro. Disponível em: $<$ www.tvebrasil.com.br/SALTO/boletins2002>. Acesso em: 3/7/2007.

SINGER, R.N.; DICK, W. Ensinando Educação Física. Uma abordagem sistêmica. Porto Alegre: Editora Globo, 1980.

SOUZA, N.P. de. Avaliação na educação física. In: VOTRE, S. (org.). Ensino e avaliação em educação física. São Paulo: Ibrasa, 1993.

SOUZA, S.Z.L. Revisando a teoria da avaliação da aprendizagem. In: SOUZA, C.P. (org.). Avaliação do rendimento escolar. 13. ed. Campinas: Papirus, 2005.

SHORES, E.; GRACE, C. Manual de portfólio: um guia passo a passo para o professor. Porto Alegre: Artmed, 2001.

SOARES, C.L. Imagens da retidão: a ginástica e a educação do corpo. In: CARVALHO, Y.M. Educação física e ciências humanas. São Paulo: Hucitec, 2001. 
SOARES, C.L.; TAFFAREL, C.N.Z.; VARJAL, E.; CASTELLANI FILHO, L.; ESCOBAR, M.O.; BRACHT, V. Metodologia do Ensino de Educação Física. São Paulo, Ed. Cortez, 1992.

TANI, G. Cinesiologia, Educação Física e Esporte: ordem emanente do caos da estrutura acadêmica. Revista Motus Corporis, Rio de Janeiro, v.3, n.2, dez, p.9-39, 1996.

; MANOEL, E.J.; KOKOBUN, E.; PROENÇA, J.E. Educação física escolar: fundamentos de uma abordagem desenvolvimentista. São Paulo: EPU/Edusp, 1988.

VASCONCELOS, C.S. Avaliação da aprendizagem: práticas de mudança por uma práxis transformadora. 6. ed. São Paulo: Ed. Libertad, 2003.

VALLE, I.A.R. Avaliação escolar: falando de portfólio e de recuperação paralela. In: ACÚRCIO M.R.B. (org.). Questões urgentes na educação. Porto Alegre/Belo Horizonte: Artmed/Rede Pitágoras, 2002.

VAYER, P. El diálogo corporal. Barcelona: Editorial Científico-médica, 1977.

VILLAS BOAS, B.M. de F. Portfólio, avaliação e trabalho pedagógico.

Campinas: Papirus, 2004.

VITÓRIA, S. O portfólio como instrumento de avaliação na organização do trabalho pedagógico. Disponível em: <http://www.revista@prendervirtual.com.br>. Acesso em 19/10/2006.

ZAINA, L.A.M. Acompanhamento do aprendizado do aluno em cursos a distancia através da Web: metodologia e ferramentas. 2001. $183 f$. Dissertação (Mestrado em Engenharia) - Escola Politécnica, USP, São Paulo.

ZABALA, A. A prática educativa. Porto Alegre: Artmed, 1994. 


\section{ANEXO I Planejamento da proposta de estudo}

\section{Proposta}

Os alunos do quarto ano do Ensino Fundamental, inseridos num projeto que estudará o conteúdo jogo, participarão do processo de avaliação realizado em diferentes momentos e com vários procedimentos: registros diários, autoavaliação e avaliação da aula. Essas práticas avaliativas serão arquivadas no portfólio e corresponderão a uma estrutura determinada. Serão realizados registros a cada aula, com foco nos objetivos de aprendizagem, e os critérios de avaliação, coerentes com o que está sendo ensinado, serão traçados de modo coletivo entre professor e alunos. A professora dará seu parecer em cada registro, com o mesmo enfoque, mas também terá o intento de conhecer como os alunos aprendem e quais as dificuldades que encontram, além de fazer uso dos dados colhidos nos portfólios dos alunos para adequar o planejamento, as ações e as intervenções de sua prática pedagógica.

\section{Objetivo geral}

Contribuir para a construção de conhecimentos significativos nas aulas de Educação Física por meio de um processo de avaliação coerente com o processo de ensino e aprendizagem.

Nessa perspectiva, considera-se que a avaliação deve estar direcionada a: a) conscientização do aluno quanto ao que está sendo ensinado, aprendido e avaliado;

b) observação do nível de aprendizagem e de compreensão dos alunos;

c) reflexão da professora e dos alunos sobre as trajetórias escolhidas no projeto de ensino, redefinindo, quando necessário, as coordenadas adotadas no trabalho;

d) comunicação entre aluno e professora para análise do processo de aprendizagem individual e coletivo;

e) realização de registros das atividades propostas nas aulas de Educação Física, tendo como foco o que aprendeu, as dificuldades que teve e o que fez para melhorar. 


\section{Pressupostos}

1. A importância da escolha dos objetivos educacionais e direcionamentos adotados no planejamento de ensino

Ao compreender que não é possível avaliar sem ter clara a concepção de ensino e aprendizagem com que se quer formar os alunos, bem como o entendimento acerca das necessidades da comunidade escolar em que o professor e o aluno estão inseridos, a proposta será organizada baseando-se nesses aspectos, que fundamentam os objetivos educacionais e os direcionamentos adotados pelo professor no planejamento de ensino. Sendo assim, serão considerados os seguintes pressupostos:

- No que diz respeito à concepção de ensino, entende-se, como expõe FERRAZ (2004), que o processo de escolarização depende de práticas de ensino que respeitem uma estrutura que envolve alguém que ensina algo a ser ensinado e alguém a quem se ensina. Essas ações especificam o trabalho do professor, que deve encarar o ato de ensinar como um meio facilitador para os alunos desenvolverem a autonomia ao refletirem sobre sua ação. Além disso, oferecer oportunidade de criar, usufruir, partilhar, produzir, reproduzir e transformar as formas culturais do movimento corporal humano.

- Quanto à concepção de aprendizagem, entende-se como uma conseqüência do ato de ensinar. Ela é o processo que se dá a partir do contato com as pessoas e com o meio ambiente, com o qual se adquirem valores, atitudes, habilidades e competências cognitivas e procedimentais, os quais são reestruturados constantemente no decorrer das práticas escolares. Nesse sentido, a estrutura da proposta pedagógica será baseada na construção do conhecimento e no processo de interação entre pares, tendo como objetivos educacionais a serem seguidos:

a) ponderar os conhecimentos prévios, a diversidade dos alunos no processo de aprendizagem, a multiplicidade de suas interações/relações com os outros, a necessidade de direcionar seus esforços para os objetivos do grupo, sem que renunciem à sua individualidade;

b) propor o conteúdo escolar com significado claro na vida cotidiana dos alunos; 
c) possibilitar a compreensão da profundidade e a relação dos conhecimentos abordados no projeto proposto;

d) desenvolver a capacidade dos alunos de identificar e formular problemas, de utilizar adequadamente fontes, dados e evidências, de chegar a algumas considerações a partir dos conhecimentos acumulados e de socializar o processo de investigação com o grupo; e) estimular o processo triádico de reflexão-ação-reflexão, ou seja, refletir, desempenhar uma ação e realizar um novo processo de reflexão sobre a ação executada;

f) possibilitar a percepção e a avaliação sobre si e o outro, em diferentes situações, que ampliem a capacidade de convivência e de respeito às diferenças.

- Com relação à concepção de avaliação adotada nessa proposta, procurarse-á considerar os princípios da avaliação formativa, por ser a concepção que melhor acolhe o portfólio, propondo-se, portanto:

a) avaliar com foco no processo de ensino e aprendizagem seguido;

b) conceber a avaliação posicionando-a a serviço da aprendizagem e não se encerrando como um fim em si mesma;

c) averiguar o que tem de ser melhorado tanto nos processos de estudo do aluno quanto nos processos de ensino do professor;

d) utilizar instrumentos coerentes com a natureza do conhecimento ensinado;

e) avaliar indicadores de aprendizagem para além dos parâmetros motores, que incluam as dimensões cognitivas e também afetivo-sociais;

f) possibilitar a inserção da avaliação no processo de ensino e aprendizagem, com a função de verificar, refletir e reestruturar decisões, por meio de iniciativas individuais e coletivas;

g) instigar a autonomia, participação e cooperação entre os indivíduos envolvidos nas práticas de ensino e avaliação;

h) abordar os resultados, relativizando a responsabilidade e estabelecendo a continuidade do ato de avaliar, refletindo quanto às causas, conseqüências e o que fazer para mudar a situação diagnosticada;

i) utilizar a nota como símbolo revelador que sintetiza o processo seguido, e não como uma marca que revela, exclusivamente, o resultado final do processo de aprendizagem do aluno. 
Para o alcance desses pressupostos de avaliação, a proposta do portfólio aponta alguns desses objetivos, sobretudo o de possibilitar à avaliação acontecer junto do processo de ensino e aprendizagem dos alunos. Esse procedimento será colocado em prática no decorrer do projeto proposto.

\section{Aspectos da prática pedagógica fundamentada no trabalho por projeto}

Para a organização do conhecimento e da prática pedagógica nessa proposta, será utilizado como referencial teórico o trabalho por projeto apresentado em HERNÁNDEZ (1998). São as razões que fundamentam essa escolha:

- o fato de se basear no referencial adotado na escola em que será posta em prática a proposta;

- a compreensão de que a idéia de projeto possibilita 0 ato de projetar, planejar uma trajetória que possa ser seguida para alcançar a realização de metas e avaliar, buscando um fim e não se tornando um fim;

- considerar o trabalho com projetos na Educação Física escolar um meio idealizador para o fomento de um ensino que busque formas não-diretivas de ensinar, que possibilite ao aluno o exercício da autonomia significando momentos em que ele possa fazer escolhas por si mesmo e aprenda a tomar decisões;

- o tema gerador do projeto proposto aos alunos será o jogo como conteúdo da cultura corporal. Para a organização do projeto serão seguidas as preconizações instituídas pelo próprio colégio, que envolvem: seleção do tema; - $\quad$ plano de conteúdos previstos; cruzamento de intenções do aluno e do professor; decisões coletivas sobre o produto final do projeto; execução do projeto, análise, interpretação, apresentação, reflexão sobre os conhecimentos ensinados e aprendidos; documentação do projeto.

3. Aspectos da organização das aulas e a inserção da prática do portfólio:

A organização das aulas seguirá o seguinte formato:

- roda de conversa sobre o que será feito na aula e reativação dos conhecimentos prévios dos alunos; 
- vivência das atividades de ensino relacionadas ao tema da aula anterior ou atividades com novo tema;

- conversa final sobre o que foi feito, promovendo a visualização das práticas realizadas e conversa sobre elas. Nesse momento, também será ressaltada a necessidade de registrar no portfólio o que foi discutido em aula, reportando-se ao que os alunos aprenderam na aula sobre determinado conteúdo.

Com relação ao portfólio, ao final de cada aula o professor fixará no painel da sala um cartaz contendo diretrizes na forma de perguntas norteadoras e critérios de avaliação para auxiliá-los na produção do registro. A sistematização dessas diretrizes será fundamentada nos objetivos educacionais do quarto ano, com foco no conteúdo jogo, como segue: explicar e executar as habilidades trabalhadas e as regras dos jogos propostos; identificar aspectos que conceituam o jogo como conteúdo inserido na cultura corporal do movimento humano; identificar valores e seguir regras nas situações de jogo; identificar e demonstrar comportamentos positivos que evidenciam respeito ao potencial, interesse e cultura dos indivíduos e determinados caracteres que definem um bom registro, tais como organização das informações registradas, criatividade, seleção de material complementar coerente com o que foi estudado.

A produção dos registros dos alunos será feita como tarefa de casa. A entrega do registro à professora ocorrerá na aula seguinte de Educação Física, que, fora do horário de aula, observará os registros de cada aluno e recolherá dados que dizem respeito ao entendimento dos conteúdos expostos a seguir:

- conceitos de habilidades motoras utilizadas nos jogos;

- conceitos que envolvam o jogo inserido na cultura corporal de movimentos;

- dificuldades encontradas;

- sugestões para melhorar;

- valores e regras seguidas nas situações de aula;

- exposição de idéias claras e a organização do registro;

- utilização de outras formas de registrar, como, por exemplo, desenhos, cartazes, maquete, ou a inserção de materiais, tais como artigos, textos e figuras que tenham relação como o conteúdo trabalhado e que complementem o registro. 
Em cada registro a professora escreverá um comentário com foco nos objetivos contemplados e aqueles que ainda precisam ser alcançados.

Após um período de aulas, que será determinado em função do planejamento e do alcance dos objetivos traçados, o professor decidirá junto aos alunos o momento em que ocorrerão as paradas para a composição do portfólio. Os alunos deverão reunir todos os registros diários elaborados nesse período e selecionar um que represente o que mais aprendeu e outro que expresse o que precisam melhorar.

Após esse momento, os alunos deverão elaborar uma justificativa do motivo de escolherem esses registros. Além disso, será proposto um questionário de auto-avaliação e outro para avaliação das aulas, cujo objetivo é investigar de maneira mais aprofundada aspectos relacionados à opinião do aluno a propósito do processo de ensino e aprendizagem seguido.

O professor recolherá o portfólio para dar o seu parecer e colherá os dados que representam os avanços e as dificuldades percebidas pelos alunos para ter um registro e organizar novas pautas de atuação.

É importante lembrar que ocorrerão duas paradas, uma no meio e outra no fim do projeto desenvolvido com os alunos, para que eles possam estabelecer relações entre o ponto de onde saíram, os avanços obtidos, as dificuldades sanadas e aquelas que ainda falta serem melhoradas, bem como reativar a memória com relação ao objetivo posto no início do projeto, como está o alcance do mesmo e o que se espera atingir no final do trimestre em que o projeto será desenvolvido.

Objetivos específicos (o que se quer atingir):

Espera-se que, por meio do portfólio, seja possível:

- na perspectiva do aluno e da professora, reconhecer que esse procedimento pode ser um meio que facilita a compreensão sobre o que é ensinado e aprendido nas aulas de Educação Física;

- a avaliação deixar de ser uma tarefa apenas da professora, com a conscientização dos alunos acerca do que estão aprendendo e o que será avaliado, e oportunize a participação dos mesmos, realizando sua autoavaliação. 
- os alunos aprenderem a registrar o que aprenderam ou não nas propostas desenvolvidas na aula de Educação Física, utilizando-se das representações vivenciadas e do emprego de outras formas de expressão da aprendizagem, como desenho, maquete, cartazes, colagens;

- identificar aspectos que precisam ser melhorados no processo de ensino e de avaliação da professora;

- os pais e outras pessoas conhecerem o processo de ensino e aprendizagem dos alunos nas aulas de Educação Física, por meio do registro construído pelos alunos e organizado no formato sugerido nas preconizações do portfólio.

- os alunos identificarem e saberem explicar o que aprenderam e como aprenderam; quais são suas dúvidas, refletindo antes, durante e após a ação;

- os alunos refletirem sobre a importância das atividades realizadas em aula para a sua aprendizagem e acompanhem seu desenvolvimento, tendo como referência as suas potencialidades e limitações;

- que os dados revelados nos portfólios dos alunos facilitem a leitura da realidade vivida pelos alunos e o pronunciamento sobre a realização das expectativas combinadas no início do projeto;

- delimitar de maneira mais clara e adequada o processo da avaliação para os alunos e a professora: objetivo, conteúdo, características, habilidades a serem avaliadas.

- a professora desenvolver a prática da ação de ensinar e realizar avaliação e ajustes de sua prática pedagógica. 


\section{ANEXO II Diário da professora-pesquisadora}

\section{Aula 1: Diário da aula}

Nessa aula o assunto foi o jogo. As crianças foram questionadas sobre o que é jogo.

As respostas citaram o jogo como alegria e diversão.

A disposição em que as crianças se encontravam (sentadas em carteiras enfileiradas) não era a mais adequada para tratar desse assunto, uma vez que jogo invoca movimentação, exultação.

Os alunos estavam interessados, mas a disposição das carteiras e o local da discussão (sala de aula) não ajudavam a manter a concentração. No final da aula, mostraram-se cansados.

Os alunos citaram muitas vezes o respeito às regras e a necessidade de diminuir os conflitos no jogo.

Eles têm dificuldade em identificar o que jogam em espaços livres com os amigos. Nas respostas sobre o que gostam de jogar, relacionavam jogo apenas aos de computador. Além disso, confundem esporte com jogo, ao mencionar ginástica artística e futebol.

Considero que houve exagero na quantidade de conceitos sobre jogo apresentada aos alunos, e esse também foi um motivo de deixar a aula cansativa e muito com foco na professora.

Quando o aluno tem um texto em mãos para acompanhar a leitura da professora é melhor porque se concentra mais. Entretanto, nessa aula o texto não chegou a tempo e tive que ler dando muita entonação, demonstrando minha motivação e dando algumas paradas para perguntar e explicar as partes mais complicadas para os alunos.

Senti ser desnecessário ler o texto "O que é jogo?".

Percebi que o assunto jogo interessa muito aos alunos. Quando se iniciou a coleta de informações sobre o que é jogo, alguns alunos que ainda não tinham dado sua opinião, levantavam a mão para ser vistos e falar a qualquer custo.

Percebi que promover um momento para pensar e colocar as idéias no lugar, principalmente ao ler o que os alunos citam, desperta neles o sentimento de terem suas palavras valorizadas ao serem utilizadas na aula. Isso aconteceu na dinâmica do saco, essa foi a parte da aula que mais Ihes chamou a atenção, 
pois concretizou o que autora citava no texto lido pela professora: o jogo não tem como definir.

Foi fornecido aos alunos um questionário para investigar os jogos que os seus pais executavam quando crianças.

\section{Aula 1: Observações da professora sobre os registros dos alunos}

Critérios de avaliação (observar se os alunos citam respostas coerentes com o que foi trabalhado na aula):

1. O que entenderam sobre: o que é jogo? Como se caracteriza o jogo?

2. Exposição de idéias claras.

3. Seleção de material para inserir no registro e expressar melhor o que compreenderam da aula.

4. Expor o que não entenderam.

TABELA 1 - Aula 1 - Observações da professora

\begin{tabular}{|l|l|}
\hline 1 (A.B.) & $\begin{array}{l}\text { Expressa uma das características } \\
\text { levantadas sobre o jogo: É importante } \\
\text { para o desenvolvimento do corpo }\end{array}$ \\
\hline 2 (B.) & Faltou. \\
\hline 3 (C.) & $\begin{array}{l}\text { Além da escrita, também desenha em } \\
\text { seu registro, expressando que gostou } \\
\text { da aula. }\end{array}$ \\
\hline 4 (F.) & $\begin{array}{l}\text { Expressa uma das características } \\
\text { levantadas sobre o jogo: Não importa } \\
\text { perder ou ganhar, o legal é participar. }\end{array}$ \\
\hline 5 (F.) & $\begin{array}{l}\text { Expressa uma das características } \\
\text { levantadas sobre o jogo: Tem que } \\
\text { saber perder ou ganhar. O jogo pode } \\
\text { ser mudado se nós não estivermos } \\
\text { gostando. }\end{array}$ \\
\hline 6 (G.B.) & $\begin{array}{l}\text { Expressa características sobre o que } \\
\text { é jogo: } \text { A gente pode mudar as regras } \\
\text { se estiver chato; existem jogos para- }\end{array}$ \\
\hline
\end{tabular}




\begin{tabular}{|c|c|}
\hline & $\begin{array}{l}\text { dos e em movimento; pode usar ou } \\
\text { não materiais; é muito divertido e tem } \\
\text { bastante movimento. }\end{array}$ \\
\hline 7 (G.R.) & Não fez. \\
\hline 8 (G.) & $\begin{array}{l}\text { Só diz que falamos sobre o que é } \\
\text { jogo. }\end{array}$ \\
\hline 9 (I.) & Faltou. \\
\hline 10 (I.C.) & $\begin{array}{l}\text { Expressa características sobre o que } \\
\text { é jogo: É essencial na infância; } \\
\text { podem ter objetos, como a queimada, } \\
\text { ou não, como o pega-pega; também, } \\
\text { é importante para o desenvolvimento } \\
\text { do nosso corpo. }\end{array}$ \\
\hline 11 (I.C.) & $\begin{array}{l}\text { Expressa-se utilizando desenhos, } \\
\text { identificando local em que a aula } \\
\text { ocorreu e o assunto, sem explicar. }\end{array}$ \\
\hline 12 (J.) & Faltou. \\
\hline $13(\mathrm{~J})$. & Faltou. \\
\hline 14 (J.B.) & $\begin{array}{l}\text { Expressa características sobre o que } \\
\text { é jogo: Necessita de regra; respeitar } \\
\text { os participantes e prestar atenção. }\end{array}$ \\
\hline 15 (J.P.) & $\begin{array}{l}\text { Disse apenas que a professora } \\
\text { mostrou o que alguns autores falam } \\
\text { sobre o que é jogo e relacionou com a } \\
\text { opinião dos alunos. }\end{array}$ \\
\hline $16(\mathrm{~K})$. & Não fez. \\
\hline 17 (L.) & Faltou. \\
\hline 18 (L.) & $\begin{array}{l}\text { Disse apenas que a professora } \\
\text { mostrou o que alguns autores falam } \\
\text { sobre o que é jogo e relacionou com a } \\
\text { opinião dos alunos. }\end{array}$ \\
\hline 19 (L.) & $\begin{array}{l}\text { Expressa características sobre o que } \\
\text { é jogo: Diverte as pessoas; é }\end{array}$ \\
\hline
\end{tabular}




\begin{tabular}{|c|c|}
\hline & necessário respeitar as suas regras. \\
\hline 20 (M.) & $\begin{array}{l}\text { Expressa características sobre o que } \\
\text { é jogo: Respeitar os participantes, } \\
\text { esperar a sua vez de fazer o ponto. }\end{array}$ \\
\hline 21 (N.M.) & $\begin{array}{l}\text { Expressa características do jogo: } \hat{E} \\
\text { divertido; tem regras que podem ser } \\
\text { modificadas. }\end{array}$ \\
\hline 22 (N.C.) & $\begin{array}{l}\text { Expressa características sobre o que } \\
\text { é jogo: A gente pode mudar as regras; } \\
\text { Expressa que lembra de uma parte do } \\
\text { texto lido que diz: "O jogo é antigo e } \\
\text { cada país tem a sua cultura ao jogar". }\end{array}$ \\
\hline $23(\mathrm{~N})$. & $\begin{array}{l}\text { Expressa características sobre o que } \\
\text { é jogo: É divertido; tem regras que } \\
\text { podem ser modificadas. }\end{array}$ \\
\hline
\end{tabular}

Percebi que os registros dos alunos são realizados sempre por meio da escrita; poucos usam outros materiais - talvez porque não sabem como fazer isso! Não têm modelos ou referências para fazem diferente.

Os registros desse dia relatam somente o que aconteceu na aula e não o que realmente aprenderam. Isso precisa ser ensinado.

No registro do aluno $4(F$.), percebe-se com muita clareza que o que mais se ressaltou nessa aula foi o conceito de jogo, principalmente nas palavras dele que usei na dinâmica do saco. Isso permitiu observar quanto foi importante ouvi-los, deixá-los participar expondo sua opinião e usar o que dizem. (prof.)

\section{Aula 2: Diário da aula}

Foi recolhido o questionário sobre os jogos dos pais.

Nessa aula o que estava planejado era o assunto De onde surgiram os jogos?, mas não foi possível porque não consegui gravar a figura do pintor Bruegel no computador para utilizá-la na discussão com os alunos. Desse modo, devido à chuva e a necessidade de ter um local para ligar a filmadora, o jogo proposto foi realizado no pátio da escola. 
O jogo proposto foi pique-bandeira; a separação dos times foi realizada pelos próprios alunos com o seguinte critério: é necessário que os times sejam mistos e bem equilibrados.

Os alunos jogavam com entusiasmo. Todos tentavam fazer algo para ajudar a equipe a fazer ponto.

Três alunos - 16 (K.), 13 (J.) e 12 (J.) - se destacaram bastante no jogo, porém só eles queriam ir para o outro campo buscar a bandeira e fazer ponto.

Nos últimos minutos da aula, os alunos sentados na roda de conversa foram questionados pela professora: Como se joga o jogo que vocês realizaram hoje? 8 (G.): Tem que ter muita energia para passar de um lado para o outro correndo muito rápido.

23 (N.): A gente precisa usar o reflexo, porque precisamos ser ágeis nesse jogo.

4 (F.): Tem que usar o reflexo para não deixar ninguém te pegar.

8 (G.): É porque precisamos ser muito rápidos.

O aluno 13 (J.) tenta justificar que no meio do jogo houve um momento em que foi pego, mas não viu e por isso não cumpriu a regra.

11 (I.C.): Nesse jogo se a gente não tiver um jeito de passar entre os amigos a gente não ganha.

\section{Observação:}

A aluna utiliza-se das mãos, enquanto explica o explicitado anteriormente, ou seja, a necessidade de desviar dos colegas procurando espaços vazios.

3 (C.): É um jogo que precisa ter atenção, porque se a gente fica distraída o amigo passa e você não percebe.

Professora questiona os alunos: Quais as exigências desse jogo?

1 (A.B.): Quando a gente passar para o outro campo, deve prestar atenção para não ser pego, também deve prestar atenção no amigo da outra equipe para não o deixar ultrapassar o nosso campo.

Após a discussão, a professora sugeriu que os alunos procurassem mais informações sobre o jogo pique-bandeira, tais como onde surgiu e se existe outra forma de jogá-lo.

Foi combinado com os alunos que o registro deveria expressar o que aprenderam ou não sobre o jogo, dizer como se joga, quais as regras, quais as 
habilidades motoras que se usam nesse jogo, quais as dificuldades que sentiram e dizer como fazer para superá-las. Além disso, deveriam registrar se houve algum problema, como foi resolvido. Ressaltou-se a necessidade de expor as idéias de forma clara e usar outros materiais para acrescentar aos registros.

\section{Aula 2: Observações da professora sobre os registros dos alunos}

Critérios de avaliação (observar se os alunos citam respostas coerentes com o que foi trabalhado em aula):

Explicação do jogo pique-bandeira, identificando:

1. Como se joga?

2. Quais as regras combinadas?

3. Quais as habilidades exigidas nesse jogo?

4. Quais os problemas que aconteceram no jogo?

5. Como resolveram os problemas? (se não foram resolvidos, pode dar sugestões sobre como poderiam tê-los resolvido).

TABELA 2 - Aula 2 - Observações da professora

\begin{tabular}{|l|l|}
\hline 1 (A.B.) & Identifica o pique-bandeira. \\
\hline 2 (B.) & \begin{tabular}{l} 
Explica o jogo pique-bandeira, \\
identificando como se joga: Os \\
jogadores quando for passar não \\
podem deixar ser pego quando for \\
pegar a bola do outro lado. Se for \\
pego devolve a bola e volta para o \\
seu lado. \\
Expõe a regra combinada: Aceitar \\
quando for pego. \\
Além de escrever, expõe um \\
desenho. \\
\hline 3 (C.)
\end{tabular} \mid \begin{tabular}{l}
\hline Identifica o nome do jogo que \\
executou: pique-bandeira.
\end{tabular} \\
\hline 4 (F.) & Explica o jogo pique-bandeira, \\
\hline
\end{tabular}




\begin{tabular}{|c|c|}
\hline & $\begin{array}{l}\text { identificando como se joga por meio } \\
\text { do desenho, no qual expressa os dois } \\
\text { times posicionados, e por meio de } \\
\text { setas expõe o caminho percorrido por } \\
\text { vários jogadores que tentam pegar a } \\
\text { bandeira. Para os jogadores pegos no } \\
\text { meio do percurso ele insere a } \\
\text { expressão "peguei", e para o que } \\
\text { consegue pegar a bandeira e fazer } \\
\text { ponto, insere "ponto para minha } \\
\text { equipe". } \\
\text { Expõe as regras combinadas: Não } \\
\text { ultrapassar as linhas do jogo e } \\
\text { respeitar que todos devem ter o } \\
\text { direito de tentaro ponto. }\end{array}$ \\
\hline $5(\mathrm{~F})$. & $\begin{array}{l}\text { Identifica o jogo pique-bandeira. } \\
\text { O problema foi que eram sempre os } \\
\text { mesmos que iam tentar fazer o ponto. } \\
\text { Expõe que conversaram e decidiram } \\
\text { que: Para não ter briga, nós fizemos } \\
\text { uma reunião e a gente falou sobre } \\
\text { quem vai ficar na defesa, e em outros } \\
\text { lugares. }\end{array}$ \\
\hline 6 (G.B.) & $\begin{array}{l}\text { Explica o jogo pique-bandeira, } \\
\text { identificando como se joga: É um jogo } \\
\text { que precisa se movimentar bastante } \\
\text { não pode passar a bola tinha passa } \\
\text { com ela nas mãos. }\end{array}$ \\
\hline 7 (G.R.) & $\begin{array}{l}\text { Explica o jogo pique-bandeira, } \\
\text { identificando como se joga: Tem que } \\
\text { ter agilidade e rapidez para se desviar } \\
\text { dos pegadores do outro time ou para } \\
\text { pegar os adversários que invadem }\end{array}$ \\
\hline
\end{tabular}




\begin{tabular}{|c|c|}
\hline & $\begin{array}{l}\text { nosso campo. } \\
\text { Expõe as regras combinadas: } \\
\text { Respeitar que todos devem ter o } \\
\text { direito de tentar o ponto. } \\
\text { Aponta as habilidades envolvidas no } \\
\text { jogo: Correr com velocidade; se } \\
\text { desviar dos pegadores. }\end{array}$ \\
\hline 8 (G.) & $\begin{array}{l}\text { Hoje jogamos pique-bandeira não foi } \\
\text { muito organizado. }\end{array}$ \\
\hline 9 (I.) & $\begin{array}{l}\text { Hoje jogamos pique-bandeira, tem } \\
\text { que segurar a bandeira e não } \\
\text { podemos deixar nos pegar. } \\
\text { Acrescenta uma pesquisa sobre a } \\
\text { origem dos jogos infantis, aponta o } \\
\text { que achou mais interessante na } \\
\text { pesquisa: Não se conhece a origem } \\
\text { desses jogos. Sabe-se apenas que } \\
\text { são práticas abandonadas por } \\
\text { adultos. }\end{array}$ \\
\hline 10 (I.C.) & $\begin{array}{l}\text { Identifica o jogo pique-bandeira. } \\
\text { Expõe as regras combinadas: Aceitar } \\
\text { quando for pego. }\end{array}$ \\
\hline 11 (I.C.) & Só falou que a aula foi legal. \\
\hline $12(\mathrm{~J})$. & $\begin{array}{l}\text { Só escreveu que jogou pique- } \\
\text { bandeira }\end{array}$ \\
\hline $13(\mathrm{~J})$. & Entregou em branco. \\
\hline 14 (J.B.) & $\begin{array}{l}\text { Explica o jogo pique-bandeira, } \\
\text { identificando como se joga: É um jogo } \\
\text { que tem que prestar atenção, ter } \\
\text { agilidade e reflexo para não ser pego } \\
\text { e tentar pegar a bandeira. } \\
\text { Expõe as regras combinadas: Aceitar } \\
\text { quando for pego; não ultrapassar as }\end{array}$ \\
\hline
\end{tabular}




\begin{tabular}{|c|c|}
\hline & $\begin{array}{l}\text { linhas do jogo e respeitar que todos } \\
\text { devem ter o direito de tentar o ponto. } \\
\text { Aponta as habilidades envolvidas no } \\
\text { jogo: Correr com velocidade; se } \\
\text { desviar dos pegadores. } \\
\text { Além de escrever, também desenhou } \\
\text { o espaço do jogo, as bandeiras e os } \\
\text { alunos posicionados nos seus } \\
\text { campos. }\end{array}$ \\
\hline 15 (J.P.) & $\begin{array}{l}\text { Explica o jogo pique-bandeira, } \\
\text { identificando como se joga: dois } \\
\text { grupos tinham que atacar o campo da } \\
\text { outra equipe e pegar a bola e levar } \\
\text { para o seu campo, mas se a pessoa } \\
\text { te pegar você vira estátua e tem que } \\
\text { esperar alguém te salvar. Acaba o } \\
\text { jogo quando alguém levar a bola até o } \\
\text { seu campo. } \\
\text { Expõe as regras combinadas: } \\
\text { Respeitar que todos devem ter o } \\
\text { direito de tentar o ponto. }\end{array}$ \\
\hline $16(\mathrm{~K})$. & $\begin{array}{l}\text { Explica o jogo pique-bandeira, } \\
\text { identificando como se joga: Este jogo } \\
\text { tem que ser rápido para não ser pego } \\
\text { e perder a chance de trazer a } \\
\text { bandeira para o seu campo e fazer o } \\
\text { ponto. }\end{array}$ \\
\hline 17 (L.) & $\begin{array}{l}\text { Aponta as habilidades envolvidas no } \\
\text { jogo: Correr com velocidade; se } \\
\text { desviar dos pegadores para não ser } \\
\text { pego. }\end{array}$ \\
\hline 18 (L.) & Expõe as regras combinadas: Não \\
\hline
\end{tabular}




\begin{tabular}{|c|c|}
\hline & $\begin{array}{l}\text { ultrapassar as linhas do jogo. } \\
\text { Aponta as habilidades envolvidas no } \\
\text { jogo: Correr com velocidade; se } \\
\text { desviar dos pegadores. } \\
\text { A dificuldade foi passar para o outro } \\
\text { time com a bola na mão. } \\
\text { Trouxe uma pesquisa que contribuiu } \\
\text { muito para o grupo porque confirmou } \\
\text { o que havia aprendido em aula sobre } \\
\text { a transformação do jogo no tempo e } \\
\text { aponta uma hipótese de onde pode } \\
\text { ter surgido a idéia do jogo pique- } \\
\text { bandeira. }\end{array}$ \\
\hline 19 (L.) & $\begin{array}{l}\text { Aponta as habilidades envolvidas no } \\
\text { jogo: Correr com velocidade; se } \\
\text { desviar dos pegadores. }\end{array}$ \\
\hline 20 (M.) & $\begin{array}{l}\text { Expõe as regras combinadas: Aceitar } \\
\text { quando for pego; não ultrapassar as } \\
\text { linhas do jogo. } \\
\text { Aponta as habilidades envolvidas no } \\
\text { jogo: correr com velocidade; se } \\
\text { desviar dos pegadores. }\end{array}$ \\
\hline 21 (N.M.) & $\begin{array}{l}\text { Explica o jogo pique-bandeira, } \\
\text { identificando como se joga por meio } \\
\text { de uma que expõe como se joga e } \\
\text { apresenta variações do mesmo. } \\
\text { Expõe as regras combinadas: Aceitar } \\
\text { quando for pego; respeitar que todos } \\
\text { devem ter o direito de tentar o ponto. } \\
\text { Aponta as habilidades envolvidas no } \\
\text { jogo: Correr com velocidade; atenção } \\
\text { ao se desviar para não ser pego. } \\
\text { Trouxe a pesquisa de dois jogos que }\end{array}$ \\
\hline
\end{tabular}




\begin{tabular}{|l|l|}
\hline 22 (N.C.) & $\begin{array}{l}\text { variam a forma de jogar o pique- } \\
\text { bandeira. }\end{array}$ \\
\hline 23 (N.) & $\begin{array}{l}\text { Explica o jogo pique-bandeira, } \\
\text { identificando como se joga: É assim } \\
\text { tem } 2 \text { times cada time tem } 1 \text { bola } 0 \\
\text { time tenta pegar a bola do outro sem } \\
\text { ser pego. }\end{array}$ \\
\hline O aluno expõe: Eu não entendi por \\
que não pode jogar a bola pro amigo \\
no pique-bandeira?
\end{tabular}

Percebi que houve pouca inserção de novos materiais ou utilização de outras formas de registrar nos registros dos alunos.

\section{Aula 3: Diário da aula}

Ressaltei a importância de registrar usando outras linguagens e inserir materiais nos registros, dando enfoque ao fato de:

- complementar e deixar os registros mais ricos, criativos e fáceis de entender;

- registrar sem ter que usar exclusivamente a escrita, e sim utilizar também outras linguagens: o desenho, a colagem de figuras, textos, fotos, maquetes, cartazes.

Eu mostro modelos de registros meus e de outros alunos.

Alguns alunos perguntaram se podiam trazer filmadora e máquina fotográfica.

Percebi que permitir fazer registros utilizando diferentes linguagens motivou os alunos a buscarem outras formas de registrar, pois uma das reclamações era 0 fato de ter que produzir registros escrevendo.

Percebi que esse interesse de produzir registros utilizando diferentes linguagens precisa ser trabalhado com os alunos, uma vez que os mesmos não têm modelos e não sabem como proceder para registrar dessa forma. Então, isso precisa ser ensinado.

Os alunos entregaram o registro da aula anterior e a professora entregou o registro que havia ficado para ler e registrar suas observações. 
$\mathrm{Na}$ sala de materiais de Educação Física eu sentei com os alunos e li os jogos apontados nas respostas da pesquisa realizada pelos alunos com os seus pais sobre como jogavam quando eram crianças. Mostrei aos alunos como havia organizado as respostas dadas pelos seus pais e pedi para confirmarem se 0 que estava escrito batia com o que haviam registrado. Após a apresentação perguntei aos alunos se havia diferença entre os jogos que os pais executavam quando eram crianças e os jogos que eles praticavam na atualidade. As respostas dos alunos apontaram que o espaço e o tempo que os pais tinham para jogar eram maiores do que o que eles têm hoje em seu tempo de lazer. Também mencionaram que isso acontece não só por falta de espaço para jogar, mas também por causa da violência que existe nas grandes cidades, que acaba limitando ainda mais seu tempo e o espaço para jogar com os amigos. Solicitei aos alunos a escolha de dois jogos apontados na pesquisa com os pais para serem praticados na aula de Educação Física. Os alunos escolheram os jogos alerta e racha (futebol).

Fomos para a quadra testar os jogos; os alunos dividiram-se em dois grupos. Cada grupo ficou com um dos jogos na metade da quadra, trocando de jogo assim que a professora apitava.

O aluno 8 (G.) reclama com a professora sobre uma forma de enviar a bola realizada por um colega que estava dificultando a sua recepção no jogo alerta. O aluno 13 (J.) dá uma dica para o aluno 12 (J.) se posicionar na frente do colega que irá enviar a bola, para que possa recebê-la melhor.

A aluna 15 (J.P.) reclama com a professora de que a goleira, a aluna 1 (A.B.), no jogo racha (futebol), estava reclamando porque a defesa ficava na sua frente.

A aluna 1 (A.B.) diz que a aluna 21 (N.M.) havia entrado na sua frente e estava atrapalhando.

Chamei o grupo que estava reclamando das atitudes da goleira e lancei a seguinte questão: Vocês já assistiram a algum jogo de futebol na TV ou em qualquer outro lugar?

1 (A.B.): Sim.

Eu falo: Quando um time perde a bola o que os jogadores desse time devem fazer? 
3 (C.): Se o meu time perde a bola eu viro defesa eu ajudo o meu goleiro a não tomar gol.

Eu falo: Mas como é que poderíamos explicar o que faz a defesa?

15 (J.P.): A gente tem que ficar no gol ajudando o goleiro, senão o goleiro pode não dar conta de ver a bola e levar um gol.

3 (C.): Eu posso dar uma dica? A 1 (A.B.) estava ficando muito dentro da área do goleiro, até ultrapassava a linha gol, por isso que as outras meninas, como a aluna 15 (J.P.), 18 (L.), 9 (I.), 11 (I.C.), começaram explicar à aluna 1 (A.B.) que isso não era bom, porque a bola passava a linha e entrava no gol.

15 (J.P.): Daí se a bola está dentro do gol já é gol.

Eu falo: 1 (A.B.), o que os jogadores da defesa devem fazer neste jogo que vocês estão jogando?

1 (A.B.): Elas me ajudam a segurar as bolas do adversário para não entrar no gol.

Eu falo: Isso mesmo, mas agora diga o que suas amigas fizeram que acabou te atrapalhando?

1 (A.B.): A defesa ficou no meio do gol, na minha frente e atrapalhou a minha visão.

A aluna 3 (C.) se manifesta, dizendo que a cabeça dela está confusa, porque já não sabe mais o que tem de fazer no jogo, e diz que foi isso que aconteceu no jogo, ninguém sabia o que fazer.

Eu falo: Quando isso acontecer, é necessário pedir tempo e conversar para entender o que está acontecendo e o que você deve fazer no jogo.

\section{Roda de conversa final:}

É retomado o problema da goleira no jogo e pergunta aos alunos como as pessoas sabem o que devem fazer num jogo?

3 (C.): O goleiro não pode só ficar dentro gol.

O aluno 16 (K.) diz que não concorda: O goleiro pode, sim, ficar no gol porque a tarefa mais importante dele é defender o gol.

Eu concordo com o aluno 16 (K.), dizendo que cada um no jogo tem a sua função; se o goleiro tiver que fazer o papel de jogador e goleiro, mesmo que isso seja permitido, ele não vai fazer bem nem uma nem outra função direito no 
jogo. Sendo assim, é necessário se concentrar no que deve fazer bem, que é defender o gol.

Eu lembro a importância de os alunos lerem seus comentários feitos nos registros e tentar melhorar os próximos registros.

\section{Aula 3: Observações da professora sobre os registros dos alunos}

Critérios de avaliação (observar se os alunos citam respostas coerentes com o que foi trabalhado em aula):

1. O que aconteceu na aula?

2. Quais foram os jogos escolhidos para serem aplicados na aula?

3. O que você aprendeu ou não?

a) Como se joga?

b) Quais as regras?

c) Quais as habilidades deste jogo?

d) Sentiu dificuldade? O que fazer para melhorar?

e) Houve problemas?

4. Exposição de idéias claras.

5. Inseriu outros materiais ou desenho?

TABELA 3 - Aula 3 - Observações da professora

\begin{tabular}{|l|l|}
\hline 1 (A.B.) & Entregou em branco. \\
\hline 2 (B.) & $\begin{array}{l}\text { Identifica os jogos alerta e futebol } \\
\text { escolhidos na aula. } \\
\text { Identifica habilidades exigidas nos jogos: } \\
\text { São jogos que precisa de velocidade, no } \\
\text { Futebol para conseguir chegar ao gol sem } \\
\text { marcação e no Alerta para fugir do amigo. }\end{array}$ \\
\hline 3 (C.) & $\begin{array}{l}\text { Identifica os jogos alerta e futebol } \\
\text { escolhidos na aula. } \\
\text { O problema foi: No futebol uma menina } \\
\text { ficou no canto do gol chorando (não } \\
\text { entendi). }\end{array}$ \\
\hline 4 (F.) & Identifica os jogos alerta e futebol \\
\hline
\end{tabular}




\begin{tabular}{|c|c|}
\hline & escolhidos na aula. \\
\hline $5(\mathrm{~F})$. & Não fez. \\
\hline 6 (G.B.) & $\begin{array}{l}\text { Identifica os jogos alerta e futebol } \\
\text { escolhidos na aula. } \\
\text { Expõe as regras do jogo alerta: Passar a } \\
\text { bola para os amigos, quando caía quem } \\
\text { pegava a bola tinha que gritar "Alerta". }\end{array}$ \\
\hline 7 (G.R.) & Não fez. \\
\hline 8 (G.) & $\begin{array}{l}\text { Identifica os jogos alerta e futebol } \\
\text { escolhidos na aula. } \\
\text { É interessante notar que ressalta que a } \\
\text { aula foi muito legal e divertida. }\end{array}$ \\
\hline 9 (I.) & $\begin{array}{l}\text { Identifica os jogos alerta e futebol } \\
\text { escolhidos na aula. } \\
\text { Como se joga alerta: Passar a bola para } \\
\text { os amigos, quando ela caía, a gente corria } \\
\text { e quem pegava a bola gritava "Alerta". } \\
\text { Como jogou futebol: a gente chutava a } \\
\text { bola se desviando dos adversários até } \\
\text { chegar no gol e chutar. }\end{array}$ \\
\hline 10 (I.C.) & $\begin{array}{l}\text { Identifica os jogos alerta e futebol } \\
\text { escolhidos na aula. } \\
\text { Expõe como jogou alerta: Passar a bola } \\
\text { com as mãos, se ela caísse tinha que } \\
\text { correr e parar quando ouvia "Alerta". } \\
\text { Expõe como jogou futebol: a gente } \\
\text { chutava a bola se desviando e passando } \\
\text { para os colegas. }\end{array}$ \\
\hline 11 (I.C.) & $\begin{array}{l}\text { Identifica os jogos alerta e futebol } \\
\text { escolhidos na aula. } \\
\text { Expõe que gostou de jogar alerta e que } \\
\text { não gostou de jogar futebol, porque sente } \\
\text { muita dificuldade: Já disse que odeio }\end{array}$ \\
\hline
\end{tabular}




\begin{tabular}{|l|l|}
\hline \multirow{1}{*}{12 (J.) } & $\begin{array}{l}\text { futebol? Eu acho chato tenho dificuldade } \\
\text { para jogar. } \\
\text { Apresenta o registro com se fosse uma } \\
\text { história em quadrinhos. }\end{array}$ \\
\hline 13 (J.) & \begin{tabular}{l} 
Não fez. \\
Identifica os jogos alerta e futebol \\
escolhidos na aula. \\
Expõe como jogou alerta: Passava a bola \\
com as mãos, se ela caísse corria e só \\
parava quando ouvia "Alerta". \\
Expõe como jogou futebol: Chutava a bola \\
até chegar ao gol. \\
Expõe as regras: respeitar que todos \\
devem ter a chance de receber a bola e \\
fazer ponto. \\
Expõe suas idéias de maneira clara. \\
Desenha os dois jogos propostos. \\
Expressa que executou o jogo que mais \\
gosta: o futebol. \\
\hline 16 (K.) \\
\hline 14 (J.B.) \\
Identifica os jogos alerta e futebol \\
escolhidos na aula. \\
Como se executa a habilidade do jogo \\
alerta, no passe de bola: Ficar na frente \\
do colega que irá enviar a bola. \\
Expõe as regras: Passar a bola para \\
todos do time.
\end{tabular} \\
\hline $\begin{array}{l}\text { A aluna consegue fazer relação do } \\
\text { conteúdo dessa aula (seleção e execução } \\
\text { de jogos retirados da pesquisa com os } \\
\text { pais) com a aula passada (solicitação da } \\
\text { pesquisa com os pais). }\end{array}$ \\
$\begin{array}{l}\text { Identifica os jogos alerta e futebol } \\
\text { escolhidos na aula. }\end{array}$ \\
\hline 10
\end{tabular}




\begin{tabular}{|c|c|}
\hline & $\begin{array}{l}\text { Identifica as habilidades exigidas nos } \\
\text { jogos: Chutar com mira no gol, passar a } \\
\text { bola de frente para o colega. } \\
\text { Desenha os dois jogos propostos. }\end{array}$ \\
\hline 17 (L.) & $\begin{array}{l}\text { Identifica os jogos alerta e futebol } \\
\text { escolhidos na aula. } \\
\text { Expõe como jogou alerta: Passava a bola, } \\
\text { quando ela caía corria e parava quando } \\
\text { ouvia "Alerta". } \\
\text { Expõe como jogou futebol: chutava a bola } \\
\text { para as colegas no gol. }\end{array}$ \\
\hline 18 (L.) & $\begin{array}{l}\text { Identifica os jogos alerta e futebol } \\
\text { escolhidos na aula. } \\
\text { Expõe suas idéias de maneira clara. } \\
\text { Desenha os dois jogos, expondo como } \\
\text { jogou. }\end{array}$ \\
\hline 19 (L.) & $\begin{array}{l}\text { Identifica os jogos alerta e futebol } \\
\text { escolhidos na aula. } \\
\text { Desenha o jogo alerta. }\end{array}$ \\
\hline 20 (M.) & $\begin{array}{l}\text { Identifica os jogos alerta e futebol } \\
\text { escolhidos na aula. }\end{array}$ \\
\hline 21 (N.M.) & $\begin{array}{l}\text { Identifica os jogos alerta e futebol } \\
\text { escolhidos na aula. }\end{array}$ \\
\hline 22 (N.C.) & $\begin{array}{l}\text { Identifica os jogos alerta e futebol } \\
\text { escolhidos na aula. } \\
\text { Expõe como jogou: O jogo alerta } \\
\text { começava com a bola passando para os } \\
\text { amigos em roda, quando caía quem } \\
\text { pegava a bola tinha que gritar "Alerta". No } \\
\text { futebol agente tinha que passar a bola } \\
\text { para os amigos e quando chegava perto } \\
\text { do gol tentava chutar forte para fazer gol. } \\
\text { Nós brincamos de futebol, eu era a goleira }\end{array}$ \\
\hline
\end{tabular}




\begin{tabular}{|l|l|}
\hline houve uns probleminhas com a defesa por \\
isso a gente não jogou muito, [os amigos \\
não entendiam que] o goleiro defende o \\
gol e a defesa que ajuda o goleiro. \\
Desenha os dois jogos posicionando \\
jogadores, delimitando o espaço, os \\
materiais do jogo. \\
\hline (N.) \\
$\begin{array}{l}\text { Identifica os jogos alerta e futebol } \\
\text { escolhidos na aula. } \\
\text { Identifica as regras: } A \text { bola deve ser } \\
\text { passada por todos. }\end{array}$ \\
\hline
\end{tabular}

\section{Observações:}

Os jogos escolhidos da pesquisa realizada com os pais motivaram os alunos tanto na aula quanto na produção dos seus registros, pois a maioria fez o registro cumprindo com os critérios preestabelecidos na aula.

Percebi que os registros estavam mais bem-feitos. Isso demonstra esforço para contemplar as sugestões feitas para melhorar o registro. Isso traz a tona quanto está sendo importante o retorno que estou dando aos alunos nos seus registros.

\section{Aula 4: Diário da aula}

A aula foi no anfiteatro, perguntei aos alunos o que eles haviam aprendido até o momento e conforme os alunos iam respondendo eu ajudava-os a lembrar de mais detalhes sobre os passos já realizados no projeto.

Pontuei o assunto da aula: De onde surgiram os jogos? Solicitei que os alunos chegassem perto e lhes mostrei o jornal Folha de São Paulo, caderno Folhinha, com a matéria "De onde surgiram os jogos infantis?". Eu disse que as informações que seriam apresentadas na aula estariam pautadas naquelas publicadas na matéria do jornal.

Com o artigo nas mãos, disse aos alunos que lá estava escrito que há várias hipóteses sobre onde surgiu o jogo, e que algumas delas serão dramatizadas na aula pelos próprios alunos. Os alunos ficaram contentes com a resposta, demonstrando entusiasmo. 
Chamei alguns alunos para representar a primeira cena, que corresponde à primeira hipótese sobre onde surgiu o jogo. É combinado rapidamente com os alunos selecionados o que devem vestir e fazer.

As crianças ficam excitadas para começar.

Conforme os alunos encenam algumas situações combinadas previamente, eu vou narrando a história. (alunos)

O mesmo acontece com a segunda hipótese.

Além da narração da história, foi apresentada a figura do pintor Bruegel, para contextualizar o século e o artista citado na matéria que em sua obra retrata os jogos realizados na Idade Média. Após isso, os alunos são chamados para mostrar com mais nitidez a figura e o nome de cada jogo retratado pelo autor. Ainda, os alunos são chamados para verem no globo terrestre onde é a Europa, local a que estava se reportando a segunda hipótese sobre onde surgiram os jogos.

Foi possível estabelecer muitas relações com a apresentação desses materiais, pois traziam indícios de onde poderia ter surgido o jogo. (aluno)

Percebeu-se nesse momento que a aula estava bem dinâmica, mas a apresentação das informações era feita somente pela professora.

Entretanto, a participação dos alunos nas dramatizações das hipóteses chamou bastante a atenção dos alunos que assistiam, todos estavam bem concentrados.

Para a terceira hipótese, no final da cena, percebeu-se que a compreensão era complexa para os alunos, razão por que pedia aos personagens congelarem em alguns momentos da cena e explicava o que estava acontecendo na história. Isso os ajudou a entender essa hipótese.

É feita, então, uma retomada das três hipóteses apresentadas e se questiona os alunos sobre o que entenderam.

A aluna 11 (I.C.) estabeleceu relação com um livro seu, que mostra crianças egípcias jogando já naquela época. (aluna)

A professora ressalta o que a aluna expôs.

A aluna 3 (C.) fala que tem um livro em que há jogos e pergunta se ela pode inserir figuras do mesmo em seu registro. 
A professora pergunta se esse livro trata do assunto que está sendo discutido na aula, pede para aluna verificar isso. Se sim, diz: É claro que pode que inserir novas informações no seu registro.

A aluna 11 (I.C.) diz que percebeu que os jogos feitos desde muito tempo atrás se parecem com os jogos que os seus pais faziam e também com jogos eles praticam nos dia atuais. (aluna)

A professora abre novamente a figura do pintor Bruegel e confirma o que a aluna 11 (I.C.) observou; todos os alunos confirmam a informação.

A aluna 10 (I.C.) diz que lembrou de um outro livro que ela já viu, o qual mostra cenários gregos com crianças portando bonecas.

A professora ressalta para a aluna e todo o resto da turma que qualquer material que eles tivessem sobre o assunto abordado na aula pode ser inserido no registro, pois isso só iria complementá-lo e deixá-lo mais rico.

Vários alunos levantaram a mão e perguntaram se podiam pesquisar.

Percebe-se que os alunos só entenderam nesse momento que podiam acrescentar pesquisas nos registros diários.

A professora aproveitou o pretexto e acrescentou que os alunos também podiam registrar utilizando-se de outras linguagens, como o recorte de uma figura, de uma parte de um artigo de jornal, revistas, trazer uma música, escultura, desenho etc. Mas advertiu que era necessário ter relação com o assunto abordado na aula.

Deu o exemplo dos registros da aula com pique-bandeira em que as alunas 9 (I.), 22 (N.M.) e 18 (L.) pesquisaram informações sobre esse jogo e o registro ficou muito mais rico.

Foram fixados na sala de aula os critérios de avaliação do registro daquele dia, para ser entregue na próxima aula.

\section{Aula 4: Observações da professora sobre os registros dos alunos}

Critérios de avaliação (observar se os alunos citam respostas coerentes com o que foi trabalhado em aula) quanto a:

1. O que você aprendeu sobre as hipóteses sobre a origem do jogo.

2. Qual hipótese considera que melhor responde a questão de onde surgiram os jogos? 
TABELA 4 - Aula 4 - Observações da professora

\begin{tabular}{|l|l|}
\hline 1 (A.B.) & $\begin{array}{l}\text { Identifica algumas hipóteses sobre a } \\
\text { origem do jogo: Os jogos podem ter } \\
\text { surgido na Grécia ou em outros } \\
\text { países. }\end{array}$ \\
\hline 2 (B.) & $\begin{array}{l}\text { Identifica algumas hipóteses sobre a } \\
\text { origem do jogo: Os jogos podem ter } \\
\text { nascido na Espanha, em Portugal ou } \\
\text { na Grécia. }\end{array}$ \\
\hline 3 (C.) & $\begin{array}{l}\text { Disse que aula foi divertida e } \\
\text { teórica; lista os amigos que } \\
\text { participaram da representação. }\end{array}$ \\
\hline 5 (F.) & $\begin{array}{l}\text { Não fez. } \\
\text { Identifica algumas hipóteses sobre a } \\
\text { origem do jogo: } \text { A professora explicou } \\
\text { exemplos sobre de onde surgiu o jogo } \\
\text { e fez um pequeno teatro e o que } \\
\text { achei mais interessante foi saber que } \\
\text { o jogo pode ter surgido da } \\
\text { necessidade das crianças mostrarem } \\
\text { o que queriam [hipótese sobre a } \\
\text { origem dos jogos exposta por Freud]. }\end{array}$ \\
\hline 6 (G.B.) & $\begin{array}{l}\text { Identifica algumas hipóteses sobre a } \\
\text { origem do jogo: Hoje aprendemos de } \\
\text { onde podem ter nascido os jogos, a } \\
\text { primeira hipótese veio dos gregos (...); } \\
\text { a segunda veio dos europeus } \\
\text { apresentam jogos desde a antiguidade, } \\
\text { quando vieram para o Brasil } \\
\text { trouxeram vários jogos que faziam em } \\
\text { sua terra. A terceira hipótese é que } \\
\text { um cientista observou crianças } \\
\text { pequenas quando jogavam o carretel }\end{array}$ \\
\hline 4
\end{tabular}




\begin{tabular}{|c|c|}
\hline & $\begin{array}{l}\text { longe é porque a mãe estava longe e } \\
\text { quando ela estava perto elas } \\
\text { puxavam o carretel. Ele acha que o } \\
\text { jogo pode ter surgido da necessidade } \\
\text { das crianças mostrarem o que } \\
\text { sentiam. }\end{array}$ \\
\hline 7 (G.R.) & $\begin{array}{l}\text { Identifica algumas hipóteses sobre a } \\
\text { origem do jogo: Fizemos um teatro } \\
\text { que representou jogos antigos feitos } \\
\text { pelos europeus, e também paleontólogo } \\
\text { que descobriu crianças gregas da } \\
\text { antiguidade que foram enterradas } \\
\text { com bonecos nas mãos, e diz que os } \\
\text { jogos podem ter surgido na Grécia. }\end{array}$ \\
\hline 8 (G.) & $\begin{array}{l}\text { Identifica algumas hipóteses sobre a } \\
\text { origem do jogo: Hoje fizemos teatros } \\
\text { de onde surgiram os jogos e existem } \\
\text { várias hipóteses relacionadas que } \\
\text { pode surgido na Grécia, na Europa ou } \\
\text { através dos bebês. }\end{array}$ \\
\hline 9 (I.) & $\begin{array}{l}\text { Identifica algumas hipóteses sobre a } \\
\text { origem do jogo: A professora mostrou } \\
\text { a } 1 \text { o hipótese de onde podem ter } \\
\text { surgido os jogos na Grécia } 4 \text { anos } \\
\text { antes de Cristo, descobriram que as } \\
\text { crianças eram enterradas com } \\
\text { brinquedos; a } 2^{\circ} \text { é a da Europa os } \\
\text { podem ter surgido lá. }\end{array}$ \\
\hline 10 (I.C.) & $\begin{array}{l}\text { Hoje a aula teórica foi muito legal, a } \\
\text { professora nos levou para o auditório } \\
\text { e mostrou várias hipóteses da Grécia, } \\
\text { a hipótese da Europa e a de Freud. }\end{array}$ \\
\hline 11 (I.C.) & A gente demonstrou as hipóteses de \\
\hline
\end{tabular}




\begin{tabular}{|c|c|}
\hline & $\begin{array}{l}\text { como surgiram os jogos infantis. } \\
\text { Exposição clara de idéias. } \\
\text { Utiliza outros materiais em seu } \\
\text { registro, figuras de crianças egípcias } \\
\text { jogando e levanta outra hipótese de } \\
\text { onde pode ter surgido o jogo: no } \\
\text { Egito. }\end{array}$ \\
\hline 12 (J.) & Não fez. \\
\hline 13 (J.) & $\begin{array}{l}\text { Os jogos podem ter surgido na Grécia } \\
\text { antiga e se espalharam pelo mundo. }\end{array}$ \\
\hline 14 (J.B.) & $\begin{array}{l}\text { Identifica algumas hipóteses sobre a } \\
\text { origem do jogo: A professora mostrou } \\
3 \text { hipóteses de onde poderiam ter } \\
\text { nascido os jogos. Na primeira hipótese } \\
\text { os paleontólogos encontraram um } \\
\text { menino na Grécia quatro anos antes } \\
\text { de Cristo crianças eram enterradas } \\
\text { com brinquedos, concluíram que os } \\
\text { jogos e as brincadeiras podem ter } \\
\text { nascido lá; a } 2^{o} \text { é a da Europa os } \\
\text { podem ter surgido lá; } 3 \text { o um } \\
\text { pesquisador investigando bebês, } \\
\text { conclui que o jogo pode ter surgido da } \\
\text { necessidade das crianças para } \\
\text { expressar o que querem. }\end{array}$ \\
\hline 15 (J.P.) & $\begin{array}{l}\text { Identifica algumas hipóteses sobre a } \\
\text { origem do jogo: Uma das hipóteses } \\
\text { de onde poderiam ter nascido os } \\
\text { jogos é a que os paleontólogos } \\
\text { encontraram um menino na Grécia } 4 \\
\text { anos antes de Cristo enterrado com } \\
\text { brinquedos, concluíram que os jogos } \\
\text { e as brincadeiras podem ter nascido }\end{array}$ \\
\hline
\end{tabular}




\begin{tabular}{|l|l|}
\hline 16 (K.) & lá. \\
\hline 17 (L.) & Não fez. \\
\hline 18 (L.) & $\begin{array}{l}\text { Identifica algumas hipóteses sobre a } \\
\text { origem do jogo: 1o hipótese os } \\
\text { paleontólogos encontraram um } \\
\text { criança grega 4 anos antes de Cristo } \\
\text { crianças eram enterradas com } \\
\text { brinquedos, concluíram que os jogos } \\
\text { e as brincadeiras podem ter nascido } \\
\text { lá; a outra hipótese é que os europeus } \\
\text { já apresentavam jogos desde há } \\
\text { muito tempo. }\end{array}$ \\
\hline 21 (N.C.) & $\begin{array}{l}\text { Identifica algumas hipóteses sobre a } \\
\text { origem do jogo: Os jogos podem ter } \\
\text { nascido na Europa ou na Grécia. }\end{array}$ \\
\hline 20 (M.) & $\begin{array}{l}\text { Identifica algumas hipóteses sobre a } \\
\text { origem do jogo: Falamos de jogos e } \\
\text { vimos que os jogos podem ter surgido } \\
\text { na Europa ou na Grécia. }\end{array}$ \\
\hline $\begin{array}{l}\text { Foi uma aula teórica a professora nos } \\
\text { mostrou 3 exemplos de onde surgiram } \\
\text { os jogos. A 10 foi que surgiram a } \\
\text { muito na Grécia, 2o foi que surgiram } \\
\text { na Europa, a } 3^{\circ} \text { foi que surgiram da } \\
\text { necessidade das próprias crianças. } \\
\text { Diz que o que mais gostou na aula foi } \\
\text { de aprender as três hipóteses, } \\
\text { explicitando cada uma e o local de } \\
\text { cada uma. } \\
\text { Expõe que a aula tratou sobre } \\
\text { algumas hipóteses sobre a origem do } \\
\text { jogo. }\end{array}$ \\
\hline \begin{tabular}{l} 
Identifica algumas hipóteses sobre a \\
\hline
\end{tabular}
\end{tabular}




\begin{tabular}{|l|l|}
\hline & $\begin{array}{l}\text { origem do jogo: Os jogos podem ter } \\
\text { nascido na Europa, na Grécia ou na } \\
\text { própria necessidade das crianças. }\end{array}$ \\
\hline $23(\mathrm{~N})$. & $\begin{array}{l}\text { Identifica algumas hipóteses sobre a } \\
\text { origem do jogo: Os jogos podem ter } \\
\text { surgido na Europa, na Grécia. }\end{array}$ \\
\hline
\end{tabular}

\section{Aula 5: Diário da aula}

Circuito de jogos de perseguição:

1) pega-pega cocorô

2) barra-manteiga

3) pique-bandeira

Nessa aula os grupos para cada estação de jogos foram escolhidos aleatoriamente pela professora, que numerou os alunos e os dividiu de acordo com a numeração recebida.

O aluno 16 (K.) traz um problema para a professora ajudá-lo a resolver, logo no início da prática dos jogos. Na mãe da rua os fugitivos não estavam esperando o pegador dizer "já" para saírem. Os fugitivos passavam a qualquer momento.

Nota-se que o aluno reconhece a necessidade de respeitar a regra de passar somente quando ouvir o comando. (alunos)

A professora chama o grupo, pede para o aluno explicitar o problema e pergunta: O que vocês podem fazer para isso ser melhorado?

16 (K.): Tem que esperar o pegador dizer "já" para sair e atravessar a área.

18 (L.): Mas o pegador fica muito tempo demorando pra dizer "já".

Vários alunos disseram que isso acontecia quando a aluna 19 (L.) era a pegadora.

19 (L.): É que quando eu ia falar um passava um pra lá, outro pra cá e eu ficava esperando eles me ouvirem.

Professora: Então vamos fazer um combinado, todos os jogadores tem que esperar o pegador dizer "já" para passar, mas o pegador deve fazer isso rápido. (alunos)

Nesse momento percebe-se a necessidade de os alunos serem estimulados a resolver o problema sozinhos. (alunos) 
Observou-se que os alunos demoravam muito para se organizar na troca das estações de jogos do circuito proposto.

Isso ocorreu porque essa turma tinha tido pouca experiência desse tipo de estrutura de aula, ou seja, circuito. (alunos)

No jogo mãe da rua, com o segundo grupo, o problema acontecia toda vez que o jogo era retomado. Todos passavam, mas o aluno 13 (J.) ficava e demorava muito para passar para o outro lado. Assim, o jogo ficava parado.

Isso aconteceu algumas vezes, então a professora resolveu intervir, pois essa atitude estava prejudicando o grupo.

A professora chama o grupo e pergunta: Por que estavam sentados?

A aluna 11 (I.C.) e o aluno 8 (G.) apontam que aluno 13 (J.) não estava levando o jogo a sério. (alunos)

Professora: Como se joga este jogo?

8 (G.): Todo mundo tem que passar.

5 (F.) complementa: Menos o pegador, que tem que pegar quem está passando.

Professora: Mas vale ficar demorando para passar para o outro lado?

2 (B.): Não.

Professora: Por quê?

Os alunos respondem juntos: Porque perde tempo no jogo e tem que ficar esperando demais.

Professora: Então, qual é a dica para isso não acontecer mais?

Os alunos respondem juntos: Passar todos rapidamente. (alunos)

No terceiro grupo, o aluno 6 (G.B.) traz um problema no pega-pega cocorô: os fugitivos não estavam respeitando a regra de agachar somente quando 0 pegador se aproximava; eles ficavam o tempo todo agachados para não serem pegos.

A professora percebe que isso é um problema porque assim ninguém joga e não se cumpre o objetivo do jogo. (alunos)

Professora chamou os alunos e perguntou qual era o combinado que eles poderiam fazer para que isso não acontecesse mais.

6 (G.B.): Só agachar quando o pegador estiver perto (mostra uma distância de três passos, mais ou menos).

Professora: Todos concordam? 
Os alunos respondem que sim e o jogo prossegue.

No quarto grupo, o aluno 16 (K.) e a aluna 15 (J.P.) trazem um problema: no pique-bandeira havia jogadores que não estavam cumprindo a regra de respeitar o espaço do jogo para tentar penetrar ou fugir com a bandeira. Eles estavam passando por fora das linhas do jogo. E também a aluna 18 (L.) estava jogando a bola (bandeira) e não passando com a bandeira na mão. (alunos)

Professora pergunta: Quais são as regras deste jogo?

Vários alunos falam ao mesmo tempo e descrevem todas as regras. E dizem que passar por fora das linhas que delimitam o espaço do jogo não vale.

Professora propõe: Então, vamos jogar e tentar cumprir essa regra?

Os alunos respondem que sim e voltam para o jogo.

No final da aula, apresentei algumas curiosidades dos jogos a partir das pesquisas trazidas pelos alunos. Foi exposta a curiosidade que a aluna 18 (L.) encontrou sobre o jogo pique-bandeira.

Após a exposição, os alunos 6 (G.B.), 12 (J.) e 8 (G.) fizeram a relação do jogo pique-bandeira com o filme Alexandre, o Grande. Eles mencionaram que nesse filme as imagens de guerra e invasão de território se parecem com o que fazem no jogo pique-bandeira. A aluna 10 (I.C.) também expõe que lembra de um filme, Panic, que conta a história de um cachorro que tinha que penetrar no campo adversário e que se assemelha muito com o que fazem no jogo piquebandeira. Já o aluno 20 (M.) faz relação do jogo pique-bandeira com jogos de tabuleiro que também apresentam a característica de invadir o campo adversário.

A professora ressalta os critérios de avaliação e pergunta aos alunos se querem acrescentar ou retirar algum critério proposto. Eles dizem que as recomendações estão boas.

\section{Observações:}

Os alunos gastam muito tempo na formação dos grupos para os jogos.

- A idéia para a próxima aula é trazer os grupos já formados, para aumentar o tempo de prática dos alunos e possibilitar mais interação entre eles.

Há demora na troca de estações. 
- A idéia para a próxima aula é fazer a mesma estrutura de circuito para ver se esse item melhorou.

Percebeu-se que todas as discussões se referiam a problemas de falta de respeito às regras, ou seja, muitos alunos tentavam burlar as regras e o grupo se manifestava.

- Para melhorar isso é necessário solicitar que eles resolvam os problemas sozinhos.

Eu acho que estou ajudando muito os alunos a resolverem seus problemas. As providências são continuar retomando na aula ("Qual é o objetivo da aula?" “Como se joga?"), pois assim é possível fazê-los refletir sobre que o que estão fazendo os impede de atingir o que se pretende com a proposta da aula.

Todos participaram ativamente da aula e pareciam bem contentes.

\section{Aula 5: Observações da professora sobre os registros dos alunos}

Critérios de avaliação (observar se os alunos citam respostas coerentes com o que foi trabalhado em aula):

1. Quais foram os jogos escolhidos para serem aplicados na aula?

2. O que você aprendeu ou não?

a) Como se joga?

b) Quais as regras?

c) Como se executam as habilidades deste jogo?

d) Sentiu dificuldade? O que fazer para melhorar?

e) Houve problemas? Como foram resolvidos?

4. Exposição de idéias claras.

5. Inseriu outros materiais ou desenho?

TABELA 5 - Aula 5 - Observações da professora

\begin{tabular}{|l|l|}
\hline 1 (A.B.) & $\begin{array}{l}\text { Identifica os jogos: 1) pega-pega } \\
\text { cocorô; 2) barra-manteiga; 3) floresta, } \\
\text { aplicados na aula. }\end{array}$ \\
\hline 2 (B.) & $\begin{array}{l}\text { Identifica os jogos: 1) pega-pega } \\
\text { cocorô; 2) barra-manteiga; 3) pique- } \\
\text { bandeira, aplicados na aula. }\end{array}$ \\
\hline
\end{tabular}




\begin{tabular}{|l|l|}
\hline 3 (C.) & \begin{tabular}{l} 
Identifica os jogos: 1) pega-pega \\
cocorô; 2) floresta; 3) barra-manteiga, \\
aplicados na aula. \\
Expõe como se joga cada um dos \\
jogos. O pega-pega cocorô era assim, \\
o pegador tinha o direito de te pegar, \\
mas você tinha o direito de abaixar \\
nisso o pegador não podia te pegar. \\
No floresta todos tinham que ficar \\
parados e quando o pegador gritava \\
“já"tinham que correr. \\
No barra-manteiga todos tinham que \\
estar com a mão estendida um dos \\
adversários ia bater na sua mão se \\
batesse por último você tinha que ir \\
atrás dele. \\
Também expõe os jogos utilizando-se \\
de história em quadrinhos. \\
\hline Identifica os jogos: 1) pega-pega \\
cocorô; 2) mãe da rua; 3) barra- \\
manteiga, aplicados na aula. \\
Expõe como se joga cada um dos \\
jogos: Fomos para a quadra e a \\
professora dividiu ela em 4 partes \\
uma para jogar pega-pega cocorô \\
quando o pegador tentasse pegar \\
você podia se salvar agachando. No \\
barra-manteiga era formar dois \\
grupos e um batia na mão do outro e \\
tinha que sair correndo para não ser \\
pego, o grupo que pegar todos do \\
outro time vence. As regras do \\
floresta eram uma pessoa ficava no
\end{tabular} \\
\hline (F.) \\
\hline
\end{tabular}




\begin{tabular}{|c|c|}
\hline & $\begin{array}{l}\text { meio e gritava "já" e todo mundo saia } \\
\text { correndo e a pessoa que estava no } \\
\text { meio tinha que pegar. } \\
\text { Identifica habilidades do jogo, quando } \\
\text { expõe: Senti dificuldade no [jogo] } \\
\text { floresta ao desviar dos colegas, eu } \\
\text { preciso de mais velocidade. }\end{array}$ \\
\hline $5(\mathrm{~F})$. & Não fez. \\
\hline 6 (G.B.) & $\begin{array}{l}\text { Identifica os jogos: 1) pega-pega } \\
\text { cocorô; 2) floresta; 3) barra-manteiga, } \\
\text { aplicados na aula. } \\
\text { Expõe como se joga cada um dos } \\
\text { jogos: no floresta não pode sair da } \\
\text { parte verde; no pega-pega cocorô o } \\
\text { pegador não pode pegar as pessoas } \\
\text { que estiverem agachadas e no barra- } \\
\text { manteiga na pode passar a linha da } \\
\text { equipe adversária. } \\
\text { Desenha o circuito de jogos que } \\
\text { praticou. }\end{array}$ \\
\hline 7 (G.R.) & Não fez. \\
\hline 8 (G.) & $\begin{array}{l}\text { Identifica os jogos: 1) pega-pega } \\
\text { cocorô; 2) barra-manteiga; 3) pique- } \\
\text { bandeira, aplicados na aula. }\end{array}$ \\
\hline 9 (I.) & $\begin{array}{l}\text { Identifica os jogos: 1) pega-pega } \\
\text { cocorô; 2) barra-manteiga; 3) pique- } \\
\text { bandeira aplicados na aula. }\end{array}$ \\
\hline 10 (I.C.) & $\begin{array}{l}\text { Identifica os jogos: 1) pega-pega } \\
\text { cocorô; 2) floresta; 3) barra-manteiga, } \\
\text { aplicados na aula. } \\
\text { Expõe como se joga cada um dos } \\
\text { jogos: no pega-pega cocorô um aluno } \\
\text { era pegador e os outros fugiam dele e }\end{array}$ \\
\hline
\end{tabular}




\begin{tabular}{|l|l|}
\hline se salvavam abaixando e se fosse \\
pego antes de se abaixar virava \\
pegador; floresta um de nós ia par o \\
meio da quadra e gritava já os outros \\
tinham que correr para o outro lado da \\
quadra sem ser pego; barra-manteiga \\
o grupo era separado em dois times \\
um de nós ia no outro lado e batia na \\
mão do amigo, o último que se batia \\
na mão tinha que correr atrás de mim, \\
se eu passasse a linha do outro lado \\
eu ganhava se me pegasse tinha ir \\
para o outro lado e era ponto para o \\
outro time. \\
Identifica habilidades: Correr e se \\
desviar com velocidade. \\
Identifica a regra importância de \\
respeitar as regras combinadas e diz: \\
Teve problemas de desrespeito às \\
regras. Eles foram resolvidas com a \\
conversa entre os amigos e com a \\
ajuda da professora. \\
A aluna colou uma figura que \\
representa os Jogos Olímpicos. \\
Percebi que não estabelecia relação \\
com a aula resolvi conversar com a \\
aluna. \\
Identifica os jogos: 1) pega-pega \\
cocorô; 2) floresta; 3) barra-manteiga, \\
aplicados na aula. \\
Expõe como se joga cada um dos \\
jogos por meio do desenho, aponta o \\
espaço dos jogos, mostra como os
\end{tabular} \mid




\begin{tabular}{|c|c|}
\hline & $\begin{array}{l}\text { jogadores devem ficar e insere balões } \\
\text { com diálogos para deixar mais claro } \\
\text { como realizou os jogos. }\end{array}$ \\
\hline 12 (J.) & Não fez. \\
\hline 13 (J.) & Não fez. \\
\hline 14 (J.B.) & $\begin{array}{l}\text { Identifica os jogos: 1) pega-pega } \\
\text { cocorô; 2) floresta; 3) barra-manteiga, } \\
\text { aplicados na aula. } \\
\text { Expõe como se joga cada um dos } \\
\text { jogos: No pega-pega cocorô, o } \\
\text { pegador, quando chegar perto dos } \\
\text { que têm fugir, tem que agachar para } \\
\text { não ser pego. No floresta, uma } \\
\text { pessoa fica no meio e as outras ficam } \\
\text { num canto e quando a pessoa que } \\
\text { está no meio fala "já" os outros têm } \\
\text { que passar sem ser pegos. No barra- } \\
\text { manteiga tem dois times, um vai ao } \\
\text { time adversário e bate na palma da } \\
\text { mão de uma pessoa que tem que sair } \\
\text { correndo atrás. } \\
\text { Desenha a estrutura da aula em } \\
\text { circuito e os jogos que praticou. }\end{array}$ \\
\hline 15 (J.P.) & $\begin{array}{l}\text { Explica o que aconteceu na aula. } \\
\text { Aponta os jogos aplicados na aula. } \\
\text { Expõe as idéias de maneira claras. }\end{array}$ \\
\hline $16(\mathrm{~K})$. & $\begin{array}{l}\text { Identifica os jogos: 1) pega-pega } \\
\text { cocorô; 2) floresta; 3) barra-manteiga, } \\
\text { aplicados na aula. } \\
\text { Expõe como se joga cada um dos } \\
\text { jogos: Aprendi que o pega-pega } \\
\text { cocorô quando alguém vai te pegar } \\
\text { você abaixa para não ser pego. No }\end{array}$ \\
\hline
\end{tabular}




\begin{tabular}{|l|l|}
\hline 17 (L.) & $\begin{array}{l}\text { mãe da rua quem era pego ficava no } \\
\text { meio para tentar pegar os outros que } \\
\text { tentava passar sem ser pego. E o } \\
\text { outro é o barra-manteiga que cada um } \\
\text { fica no seu campo e tem que bater na } \\
\text { mão do outro e correr para ele não te } \\
\text { pegar até chegar no seu campo. }\end{array}$ \\
\hline 19 (L.) & $\begin{array}{l}\text { Identifica os jogos: 1) pega-pega } \\
\text { cocorô; 2) floresta; 3) barra-manteiga, } \\
\text { aplicados na aula. } \\
\text { Expõe como se joga cada um deles: } \\
\text { Barra-manteiga eu entendi que se faz } \\
\text { dois grupos e que as crianças de } \\
\text { cada grupo tem que ser rápida para } \\
\text { não ser pega depois "do tapa" na } \\
\text { mão. Pega-pega não pode deixar o } \\
\text { pegador tocar antes de abaixar. Mãe } \\
\text { da rua precisa ter velocidade para não } \\
\text { te pegarem e para passar pela rua até } \\
\text { chegar ao outro lado. } \\
\text { Identifica as habilidades desse jogo: } \\
\text { Correr e se desviar. } \\
\text { Identifica os jogos: 1) pega-pega } \\
\text { cocorô; 2) barra-manteiga; 3) pique- } \\
\text { bandeira, aplicados na aula. } \\
\text { Expõe as idéias de maneira clara. } \\
\text { A aluna traz uma curiosidade exposta } \\
\text { pela professora no final da aula sobre } \\
\text { o jogo pega-pega cocorô: cocorô, } \\
\text { essa brincadeira é chamada assim no } \\
\text { nordeste e aqui é chamada de } \\
\text { agacha-agacha. } \\
\text { Identifica os jogos: 1) pega-pega }\end{array}$ \\
\hline 10
\end{tabular}




\begin{tabular}{|c|c|}
\hline & $\begin{array}{l}\text { cocorô; 2) barra-manteiga; 3) pique- } \\
\text { bandeira, aplicados na aula. }\end{array}$ \\
\hline 20 (M.) & $\begin{array}{l}\text { Identifica os jogos: 1) pega-pega } \\
\text { cocorô; 2) barra-manteiga; 3) pique- } \\
\text { bandeira, aplicados na aula. }\end{array}$ \\
\hline 21 (N.M.) & $\begin{array}{l}\text { Identifica os jogos: 1) pega-pega } \\
\text { cocorô; 2) floresta; 3) barra-manteiga, } \\
\text { aplicados na aula. } \\
\text { Expõe como se joga através de } \\
\text { desenho, identificando cada jogo por } \\
\text { meio do espaço e do movimento } \\
\text { específico dos jogadores. } \\
\text { Ainda expõe: Cada vez que a } \\
\text { professora apitava tínhamos de trocar } \\
\text { de jogo. }\end{array}$ \\
\hline 22 (N.C.) & $\begin{array}{l}\text { Identifica os jogos: 1) pega-pega } \\
\text { cocorô; 2) floresta; 3) barra-manteiga, } \\
\text { aplicados na aula. } \\
\text { Expõe como se jogam os jogos: No } \\
\text { barra manteiga um time fica de um } \\
\text { lado da quadra e canta barra } \\
\text { manteiga (...) 1,2,3 batendo na mão } \\
\text { do amigo e quando a música acaba o } \\
\text { ultimo amigo corre atrás para pegar } \\
\text { quem bateu na sua mão. Quem for } \\
\text { pego vai para o time adversário. } \\
\text { Floresta é assim, igual ao mãe da rua, } \\
\text { uma criança fica no meio fala 1, } 2,3 \text {, } \\
\text { e já, no meio tenta pegar alguém } \\
\text { quem for pego vira mão dono da } \\
\text { floresta. } \\
\text { Identifica as habilidades desse jogo: } \\
\text { correr e se desviar. }\end{array}$ \\
\hline
\end{tabular}




\begin{tabular}{|l|l|}
\hline $23(\mathrm{~N})$. & $\begin{array}{l}\text { Identifica as regras: se empenhar ao } \\
\text { máximo e respeitar as regras } \\
\text { combinadas. }\end{array}$ \\
\hline $\begin{array}{l}\text { Identifica os jogos: 1) pega-pega } \\
\text { cocorô; 2) floresta; 3) barra-manteiga, } \\
\text { aplicados na aula. } \\
\text { Senti dificuldade no jogo Floreta } \\
\text { porque eu não sabia que no jogo tinha } \\
\text { que esperar o pegador falar já. }\end{array}$ \\
\hline
\end{tabular}

\section{Aula 6: Diário da aula}

A aula foi prática, com a aplicação de jogos distribuídos em três estações: quebra-canela, pula-sela, aumenta-aumenta.

O objetivo dessa aula foi conhecer as regras dos jogos, executar a habilidade de saltar de diferentes formas e alturas em diferentes espaços, identificar os conceitos de como saltar, esforçar-se para melhorar e se organizar nas trocas de estação de jogos.

Uma iniciativa acertada foi trazer organizados os componentes das equipes de cada estação, já arranjados, uma vez que o objetivo era deixar os grupos mais heterogêneos e evitar as "panelinhas". Essa iniciativa também ajudou a aumentar o tempo de prática dos alunos, uma vez que a escolha das equipes nessa aula poderia demorar. (prof.)

No pula-sela os alunos estavam sentindo dificuldade porque havia pouca distância entre as selas; as selas estavam muito baixas, o que dificultava para o jogador que saltava sem pôr a mão nas costas do amigo, como solicitava a regra. (alunos)

Fiz uma marca no chão para aumentar a distância entre as selas, o que ajudou os alunos a entenderem como deveria ocorrer a organização da fila de selas após os saltos de um amigo. Também foi inserida a regra para aqueles que faziam papel de sela: não podiam se abaixar muito, a ponto de apoiar os joelhos no chão. (prof.)

No jogo quebra-canela, as alunas 18 (L.) e 17 (L.) não estavam saltando, só estavam passando a perna no bastão. (aluno) 
Eu me aproximei das alunas e as retirei do jogo para questioná-las sobre qual era objetivo do jogo. Elas explicitaram corretamente o objetivo.

Perguntei, ainda: Se vocês passam a perna deste jeito no bastão, vocês estão cumprindo com o objetivo do jogo?

Elas responderam que não. Eu conversei com as alunas e solicitei que se esforcem mais, pois sabia que elas conseguiriam fazer. A partir daí, as alunas voltaram ao jogo e passaram a realizar o jogo de maneira adequada.

Nesse jogo, o aluno 7 (G.R.) demonstrou bastante dificuldade: só passava a perna no bastão e não saltava. Eu me aproximei do aluno e, no decorrer de algumas execuções, chamava-o e dava-Ihe uma dica para melhorar seu salto. (aluno)

No jogo aumenta-aumenta não houve problemas, todos os alunos demonstraram bastante entusiasmo ao executá-lo.

Observou-se que a organização da aula em três estações de jogos foi muito produtiva para os alunos, pois possibilitou a execução dos jogos com grupos menores de alunos, estimulou os alunos a se organizarem, ajudou a ver quem estava com dificuldades e sistematizar melhor os conhecimentos aprendidos com os jogos propostos. (prof.)

$\mathrm{Na}$ roda de conversa, a professora apresentou, rapidamente, para os alunos algumas curiosidades sobre os jogos executados: em que lugar é mais praticado no país, a origem de suas regras etc. (alunos)

Perguntou aos alunos por que, no pula-sela, alguns não estavam saltando? 18 (L.): A sela estava muito baixa. (aluno)

A aluna 15 (J.P.) fala que esse jogo se parece com um brinquedo do Bosque Maia.

Retoma-se a pergunta.

3 (C.): Para que isso não aconteça a sela não pode estar nem muito baixa e nem muito alta, senão fica difícil saltar.

Os alunos são questionados: Como esta dica da 3 (C.) pode ser posta em prática no jogo? Como regular a altura para que ela fique nem muito baixa e nem muito alta?

3 (C.): O amigo que vai pular é que tem que ver e pedir para a sela subir mais ou descer um pouco. 
13 (J.): É a gente que sabe a altura que consegue saltar, algumas vezes tinha gente que subia muito o bastão e eu não conseguia saltar.

16 (K.): A 18 (L.) só passava a perna e não se esforçava para saltar nos jogos.

Líva: Eu já falei que estava muito baixo, como é que eu ia pular? (aluno)

Professora tenta sistematizar o que foi discutido quanto ao jogo pula-sela:

1. Os amigos ficavam com a sela muito baixa e não dava para saltar;

2. Havia colegas que faziam a sela alta demais e quando o colega que ia saltálo pedia para abaixar ele não o fazia.

Prof.: Como é que podemos resolver estes problemas?

12 (J.): Quando eu ia pular eu não também não conseguia porque estava muito alto.

Professora: Você pedia para o colega abaixar?

12 (J.): Sim.

1 (A.B.): $O 7$ (G.R.) pedia para abaixar eu abaixava, já o 6 (G.B.) pedia para subir e eu fazia o que ele queria. Eu acho que assim tentava ajudar os meus colegas.

A aluna 19 (L.) identifica outro problema: No quebra-canela tinha gente que estava batendo a perna no bastão, às vezes os amigos seguravam o bastão muito alto e outras muito abaixo. Quando eu ia pular elas mexiam o bastão, aumentavam a altura e eu batia minha perna no bastão.

Professora pergunta aos alunos qual era a regra desse jogo, e se isso estava certo.

14 (J.B.): Este problema acontecia mesmo.

21 (M.): Tinha gente que só passava a perna. (aluno)

Professora: Deste modo, o objetivo do jogo era cumprido?

4 (F.): Era necessário achar a melhor medida para saltar bem esse jogo também.

10 (I.C.) diz que sentiu a mesma dificuldade explicitada pela aluna 14 (J.B.).

Pergunto: $O$ que você falaria para estes amigos melhorarem na próxima vez que for jogar o quebra-canela?

10 (I.C.): Deixar o braço parado e não ficar mexendo o bastão. (aluno) 


\section{Aula 6: Observações da professora sobre os registros dos alunos}

Critérios de avaliação (observar se os alunos citam respostas coerentes com o que foi trabalhado em aula):

1. O que aconteceu na aula?

2. Quais foram os jogos escolhidos para serem aplicados na aula?

3. O que você aprendeu ou não?

a) Como se joga?

b) Quais as regras?

c) Como se executam as habilidades deste jogo?

d) Sentiu dificuldade? O que fazer para melhorar?

e) Houve problemas?

4. Exposição de idéias claras.

5. Inseriu outros materiais ou desenho?

TABELA 6 - Aula 6 - Observações da professora

\begin{tabular}{|l|l|}
\hline 1 (A.B.) & Não trouxe. \\
\hline 2 (B.) & Não trouxe. \\
\hline 3 (C.) & $\begin{array}{l}\text { Diz o que aconteceu na aula. } \\
\text { Identifica quais foram os jogos } \\
\text { praticados na aula. } \\
\text { Insere o desenho do jogo, revela a } \\
\text { dinâmica do jogo, a posição dos } \\
\text { jogadores, o deslocamento e a } \\
\text { organização espacial do jogo. }\end{array}$ \\
\hline 4 (F.) & $\begin{array}{l}\text { Diz o que aconteceu na aula. } \\
\text { Identifica quais foram os jogos } \\
\text { praticados na aula, as regras e as } \\
\text { habilidades exigidas nos jogos. } \\
\text { Sentiu dificuldade no pula-sela: Foi } \\
\text { pular em cima do amigo porque tinha }\end{array}$ \\
\hline
\end{tabular}




\begin{tabular}{|c|c|}
\hline & $\begin{array}{l}\text { vez que ficava auto ou baixo demais. } \\
\text { Desenha os jogos, utilizando-se de } \\
\text { setas para demonstrar o deslocamento } \\
\text { dos jogares e como jogou. }\end{array}$ \\
\hline $5(\mathrm{~F})$. & $\begin{array}{l}\text { Diz o que aconteceu na aula. } \\
\text { Identifica quais foram os jogos praticados } \\
\text { na aula. } \\
\text { Diz que houve problemas com os } \\
\text { amigos: Tinha gente que pulava } \\
\text { errado, como passava uma perna } \\
\text { depois a outra. } \\
\text { Desenha a organização espacial dos } \\
\text { jogos e o posicionando dos jogadores. }\end{array}$ \\
\hline 6 (G.B.) & $\begin{array}{l}\text { Diz o que aconteceu na aula. } \\
\text { Identifica quais foram os jogos } \\
\text { praticados na aula, aponta as regras. }\end{array}$ \\
\hline 7 (G.R.) & $\begin{array}{l}\text { Diz o que aconteceu na aula. } \\
\text { Identifica quais foram os jogos } \\
\text { praticados na aula. }\end{array}$ \\
\hline 8 (G.) & Não fez. \\
\hline 9 (I.) & $\begin{array}{l}\text { Diz o que aconteceu na aula. } \\
\text { Identifica quais foram os jogos } \\
\text { praticados na aula. }\end{array}$ \\
\hline 10 (I.C.) & $\begin{array}{l}\text { Expõe: Na hora de pular no Aumenta- } \\
\text { aumenta eu não conseguia. Melhore } \\
\text { quando corri rápido, pulei melhor } \\
\text { mais alto. O problema foi no quebra- } \\
\text { canela, as pessoas seguravam muito }\end{array}$ \\
\hline
\end{tabular}




\begin{tabular}{|c|c|}
\hline & $\begin{array}{l}\text { alto o bastão. Isto foi resolvido a partir } \\
\text { do momento que pudemos dizer qual } \\
\text { a melhor altura para cada um. }\end{array}$ \\
\hline 11 (I.C.) & $\begin{array}{l}\text { Diz o que aconteceu na aula. } \\
\text { Identifica quais foram os jogos } \\
\text { praticados na aula. } \\
\text { Exposição de idéias claras. }\end{array}$ \\
\hline $12(\mathrm{~J})$. & Não fez. \\
\hline $13(\mathrm{~J})$. & Não fez. \\
\hline 14 (J.B.) & Não fez. \\
\hline 15 (J.P.) & $\begin{array}{l}\text { Diz o que aconteceu na aula. } \\
\text { Identifica quais foram os jogos } \\
\text { praticados na aula. } \\
\text { Sentiu dificuldade no pula-sela. }\end{array}$ \\
\hline $16(\mathrm{~K})$. & Não fez. \\
\hline 17 (L.) & $\begin{array}{l}\text { Diz o que aconteceu na aula. } \\
\text { Identifica quais foram os jogos } \\
\text { praticados na aula. } \\
\text { Aponta que sentiu dificuldade no } \\
\text { quebra-canela: Tive um problema, } \\
\text { porque eu pedi para abaixar e não } \\
\text { abaixavam. } \\
\text { Diz que resolveu conversando com os } \\
\text { amigos. }\end{array}$ \\
\hline 18 (L.) & $\begin{array}{l}\text { Diz o que aconteceu na aula. } \\
\text { Identifica os jogos praticados na aula }\end{array}$ \\
\hline
\end{tabular}




\begin{tabular}{|c|c|}
\hline & e explica como jogou. \\
\hline 19 (L.) & $\begin{array}{l}\text { Diz o que aconteceu na aula. Expõe } \\
\text { as regras dos jogos. } \\
\text { Inseriu um desenho do jogo aumenta- } \\
\text { aumenta. }\end{array}$ \\
\hline 20 (M.) & $\begin{array}{l}\text { Diz o que aconteceu na aula. } \\
\text { Identifica quais foram os jogos } \\
\text { praticados na aula. } \\
\text { Aponta o que aprendeu na aula. } \\
\text { As regras. } \\
\text { Exposição de idéias claras. }\end{array}$ \\
\hline 21 (N.M.) & Não fez. \\
\hline 22 (N.C.) & $\begin{array}{l}\text { Diz o que aconteceu na aula. } \\
\text { Identifica os jogos praticados na aula, } \\
\text { expõe como jogou, as regras e as } \\
\text { habilidades exigidas nos jogos. } \\
\text { A aluna escreve que manter a altura } \\
\text { que o amigo pediu quando saltava foi } \\
\text { a dica que a ajudou a melhorar o salto } \\
\text { no quebra-canela. }\end{array}$ \\
\hline $23(\mathrm{~N})$. & $\begin{array}{l}\text { Diz o que aconteceu na aula. } \\
\text { Identifica quais foram os jogos } \\
\text { praticados na aula. } \\
\text { Aponta o que aprendeu na aula: como } \\
\text { jogou, as regras e as habilidades } \\
\text { exigidas nos jogos. Também desenha } \\
\text { os jogos propostos. }\end{array}$ \\
\hline
\end{tabular}




\section{Aula 7: Diário da aula}

Primeiro, na sala de aula, decidiu-se fazer uma retomada nos objetivos do projeto. A professora começou questionando os alunos.

Prof.: Qual é o tema do nosso projeto?

Alunos: Fala sobre jogos da cultura das crianças.

Prof.: Qual é o nome que havíamos escolhido pra esse projeto?

Alunos: Jogos da Escola.

Prof.: Para que estudar os jogos das crianças? Quais são os objetivos?

A partir daí, eu fui tomando nota na lousa sobre o que os alunos iam falando. As anotações iam tomando um formato de esquema:

Conhecer jogos da cultura das crianças e saber ensinar.
Saber jogar atingindo os objetivos dos jogos.
Saber resolver os problemas para que os jogos aconteçam

Como vamos ver se aprendeu ou não o que foi ensinado?

\section{Para que serve o diário de registros que vocês fazem?}

Síntese das respostas dos alunos: Para lembrar como se joga, ensinar a outros amigos, registrar $o$ que aprendemos ou não na aula.

\section{Para que serve 0 portfólio?}

Para selecionar momentos que aprendemos e ver o que precisamos melhorar.
Por que são feitas filmagens?

Para o professor avaliar o que estamos aprendendo ou não na aula.

Tudo isso leva à nota final.

Produção de um livro de jogos para ensinar outras crianças a jogarem os jogos aprendidos. 
O esquema foi construído de maneira coletiva, pois os alunos respondiam às questões feitas pela professora e ela interpretava, reestruturava ou sintetizava o que os alunos diziam para passar para o esquema na lousa, perguntando aos alunos se era isso o que queriam dizer, se estava certo ou não o modo como foi registrado.

\section{Observações:}

Para a construção do mapa conceitual feito para nortear os alunos quanto aos objetivos (o que já foi alcançado e o precisa ser atingido) do projeto, foram usados os primeiros minutos da aula na sala de leitura. Nesse local não há carteiras e os alunos puderam ficar mais à vontade Foi interessante notar que ao utilizaram outro lugar que não era a sala de aula os alunos mantiveram-se mais concentrados.

Percebi que a construção do mapa conceitual possibilitou observar o que os alunos haviam aprendido e revelar o que não ficou muito claro.

Prometi aos alunos digitar esse mapa para que todos, posteriormente, tivessem esse registro no seu portfólio.

$\mathrm{Na}$ quadra o jogo proposto foi o da peteca. A professora expôs rapidamente que jogar peteca é uma prática que tem origem na cultura indígena e que hoje é muito praticada no estado de Minas Gerais.

Foi proposto um jogo em que os alunos faziam duplas e jogavam peteca um para o outro, utilizando a habilidade do voleio, cumprindo com os seguintes objetivos:

a) não deixar a peteca cair;

b) mandar a peteca para o amigo voleando.

Uma das regras colocadas é que não valia segurar a peteca e jogá-la sem volear.

Percebeu-se que nas primeiras tentativas os alunos só estavam preocupados em tentar volear a peteca alto e longe não havia preocupação em fazer a peteca chegar ao amigo. Mas, mesmo assim, a professora os deixou explorar um pouco a habilidade do voleio, uma vez que essa habilidade foi pouco trabalhada nos anos anteriores por esses alunos. (alunos)

Depois de um tempo, o jogo foi parado e retomados os objetivos traçados anteriormente para esse jogo: a) não deixar a peteca cair; b) mandar a peteca 
para o amigo voleando. Eu ainda pergunto aos alunos o que eles faziam para cumprir com o objetivo de fazer com que a peteca chegasse na mão do amigo. 2 (B.): Eu tenho que jogar na direção do amigo.

A professora ressalta que a resposta está certa e complementa então que a dica é olhar onde o amigo está para enviar a peteca. (aluno)

Notou-se que, toda vez que a peteca vinha para o aluno 4 (F.) volear, ele chutava-a e não se esforçava para realizar o jogo como havia sido combinado. (aluno)

A aluna 22 (N.C.) se esforçou muito nesse jogo.

O aluno 13 (J.) mandava a peteca sem se preocupar em fazê-la chegar à mão do amigo. Interpreta-se que esse aluno queria mostrar que sabia mais, era mais forte, e assim jogava cada vez mais forte, alto e longe. Ele foi chamado para conversar em particular e pontuou-se a atitude que estava prejudicando seu companheiro. (aluno)

Foi parado novamente o jogo e retomaram-se rapidamente os objetivos que precisavam procurar atingir. Solicitou-se que os alunos se pronunciassem sobre quais eram as dicas para fazer com que esses objetivos fossem atingidos.

11 (I.C.): Jogar na direção do amigo, olhar onde está seu alvo.

1 (A.B.): A peteca tem que ser voleada utilizando a palma da mão.

A professora ainda pergunta: $O$ que o amigo que recebe a peteca também pode fazer para não deixá-la cair?

1 (A.B.): O amigo tem que ir na direção da peteca.

3 (C.): Prestar atenção na peteca.

16 (K.): Não sei.

Professora: Então, a terceira dica é ficar de olho para onde a peteca está indo e se deslocar na sua direção para conseguir pegá-la?

6 (G.B.): Outra dica é tentar volear com a mão debaixo da peteca.

23 (N.): Quando eu voleava a peteca para cima ela não chegava no meu amigo.

Percebeu-se, nesse momento, que todos estavam se esforçando para cumprir com os objetivos e as dicas que haviam descoberto no decorrer da aula. Porém, vale ressaltar que não era fácil fazer o que foi proposto, pois o voleio com peteca era uma habilidade difícil para os alunos. 
Percebe-se que 0 trabalho em duplas aumentou o número de tentativas realizadas pelos alunos e diminuiu os conflitos a respeito de regras na aula.

\section{Na roda de conversa:}

3 (C.): O jogo de peteca parece com vôlei.

Professora: Sim, porque usamos a habilidade de volear, na qual não pode reter a bola nas mãos como acontece em outras habilidades como o passe e a recepção.

13 (J.): Eu entendi que para esse jogo dar certo é preciso ver onde está o colega para volear certo e ir na direção da peteca para receber bem, sem deixar cair.

8 (G.): A peteca não pode cair, para isso os amigos devem ficar perto.

22 (N.C.): Segurar no lado certo da peteca e bater com a palma da mão, não pode pegar nas penas.

3 (C.): Bater bem no "bumbum" da peteca.

6 (G.B.): A gente tem que ir de encontro com a peteca para recebê-la bem, porque se ficar longe a gente não consegue pegá-la.

12 (J.): É importante mirar no amigo quando for volear.

4 (F.): Ir na direção da peteca para voleá-la direito ao amigo. (alunos)

A manifestação dos alunos no final da aula para falar o que haviam aprendido demonstrou que os conteúdos foram significativos para eles. Todos apresentaram respostas coerentes com o que foi ensinado.

\section{Aula 7: Observações da professora sobre s registros dos alunos}

Critérios de avaliação (observar se os alunos citam respostas coerentes com o que foi trabalhado em aula):

1. Como se joga?

2. Sentiu dificuldades? Como melhorar?

3. Houve algum problema na aula, como foi resolvido?

4. Inseriu outros materiais ou desenho? 
TABELA 7 - Aula 7 - Observações da professora

\begin{tabular}{|l|l|}
\hline 1 (A.B.) & Não fez. \\
\hline 2 (B.) & Não fez. \\
\hline 3 (C.) & $\begin{array}{l}\text { Descreve como jogou. } \\
\text { Complementa as suas explicações } \\
\text { sobre as dicas que aprendeu na aula } \\
\text { utilizando-se do desenho. }\end{array}$ \\
\hline 4 (F.) & Não fez. \\
\hline 5 (F.) & $\begin{array}{l}\text { Expõe as dicas que aprendeu na aula } \\
\text { para volear bem: Prestar atenção na } \\
\text { peteca; jogar na mão do amigo; correr } \\
\text { atrás da peteca; temos que segurar } \\
\text { direito a peteca senão a peteca cai. }\end{array}$ \\
\hline 6 (G.B.) & Não fez. \\
\hline 7 (G.R.) & Não fez. \\
\hline 9 (I.) & Não fez. \\
\hline 12 (J.) & $\begin{array}{l}\text { Descreve como jogou. } \\
\text { Diz que sentiu dificuldade para volear: } \\
\text { Foi difícil bater na peteca. } \\
\text { Expõe a dica, utilizando-se do } \\
\text { desenho: jogar na direção do amigo. }\end{array}$ \\
\hline 10 (I.C.) & $\begin{array}{l}\text { Descreve como jogou. } \\
\text { A dificuldade que sentiu foi: A peteca } \\
\text { caía várias vezes, porque a gente não } \\
\text { se concentrava e também batemos } \\
\text { com a palma da mão mal. } \\
\text { As dicas que aprendeu na aula: Bater } \\
\text { a peteca com a palma da mão e } \\
\text { prestar atenção para ver aonde ela } \\
\text { vai. }\end{array}$ \\
\hline Não fez. \\
Não fez. \\
Não fez. \\
\hline 10
\end{tabular}




\begin{tabular}{|c|c|}
\hline 14 (J.B.) & $\begin{array}{l}\text { Descreve como jogou. } \\
\text { Sentiu dificuldade: Tive dificuldade } \\
\text { para volear a peteca. } \\
\text { Hoje jogamos peteca. A professora } \\
\text { nos disse que a peteca vem dos } \\
\text { índios por isso tem penas. }\end{array}$ \\
\hline 15 (J.P.) & Não fez. \\
\hline $16(\mathrm{~K})$. & $\begin{array}{l}\text { Descreve com jogou. } \\
\text { Explicita: Eu não conseguia volear a } \\
\text { peteca para o amigo só as vezes que } \\
\text { eu acertava. } \\
\text { Complementou suas explicações } \\
\text { sobre o que aprendeu na aula } \\
\text { utilizando-se do desenho, mostrando } \\
\text { uma dica que aprendeu na aula, que } \\
\text { é a de volear na direção do amigo. }\end{array}$ \\
\hline 17 (L.) & $\begin{array}{l}\text { Desenha como jogou. } \\
\text { Expõe: Eu entendi que no jogo de } \\
\text { peteca tem que ter velocidade para } \\
\text { poder voleá-la e também prestar } \\
\text { atenção na direção da peteca. }\end{array}$ \\
\hline 18 (L.) & $\begin{array}{l}\text { Descreve com jogou. } \\
\text { O dia em que joguei peteca foi muito } \\
\text { difícil conseguir volear a peteca. } \\
\text { Expõe: Hoje aprendi algumas dicas } \\
\text { para jogar peteca: espalmar a peteca; } \\
\text { jogar a peteca em direção ao amigo; ir } \\
\text { em direção à peteca. }\end{array}$ \\
\hline 19 (L.) & $\begin{array}{l}\text { Sentiu dificuldade para volear: } A \\
\text { peteca caía porque ia para outra } \\
\text { direção. } \\
\text { Expõe as dicas: Tem que prestar } \\
\text { atenção não só na hora de volear e }\end{array}$ \\
\hline
\end{tabular}




\begin{tabular}{|l|l|}
\hline 20 (M.) & de receber a peteca. \\
\hline 21 (N.M.) & $\begin{array}{l}\text { Expõe dificuldade: Hoje foi uma aula } \\
\text { prática e nós treinamos peteca eu tive } \\
\text { uma certa dificuldade para pegar e } \\
\text { jogar para o amigo. }\end{array}$ \\
\hline 22 (N.C.) & Não fez. \\
\hline 23 (N.) & Não fez. \\
\hline
\end{tabular}

A metade dos alunos não fez o registro. Percebe-se que quando os alunos executam um jogo em que a habilidade exigida tem um grau de dificuldade maior ou houve conflitos difíceis de resolverem, eles se esquecem de fazer 0 registro ou o fazem sem se preocupar em cumprir com todos os critérios propostos.

\section{Aula 8: Diário da aula}

Essa aula foi em sala, a primeira coleta de registros para construção da pasta do portfólio.

Os alunos estavam ansiosos e faziam muito barulho. Eu iniciei a aula com a leitura do texto de apresentação do portfólio. Esse texto firmava com os alunos o que é o portfólio, para que serve, quais os objetivos e a quais as suas responsabilidades e as minhas quanto ao processo de avaliação da aprendizagem por meio desse instrumento.

Na seqüência da aula as tarefas foram as seguintes:

1. rever todos os registros;

2. escolher aquele que representa o que mais aprendeu;

3. escolher aquele que representava o que menos aprendeu, ou seja, que sentiu mais dificuldade e precisa melhorar;

4. colocar os registros, textos referentes ao portfólio e ao projeto na pasta e de acordo com a ordem estabelecida pela professora.

Deu a maior confusão enquanto os alunos guardavam os registros e textos, e eu precisei ajudar alguns alunos a se organizarem.

Após terem guardado tudo, foi solicitado aos alunos que sentassem em roda com as pastas. Senti todos muito felizes com as pastas do portfólio. Os alunos 
também demonstraram que haviam conseguido enxergar quanto havia aprendido.

A próxima tarefa proposta aos alunos foi escrever na folha verde por que escolheram aquele registro para representar o que mais haviam aprendido no projeto sobre jogos até aquele momento. Já na folha de cor azul os alunos tinham que escrever o que mais sentiram dificuldade no projeto sobre jogos até aquele momento.

Essa tarefa não foi possível ser contemplada na aula e assim propôs-se como tarefa de casa.

\section{Observações:}

A alegria dos alunos por estarem com a pasta em suas mãos era nítida. E esse sentimento não era só por parte dos alunos, era também meu, como professora, que podia ver quanto o portfólio revelava o esforço dos alunos e do meu trabalho.

Admito que a insegurança e a falta de maturidade com esse tipo de trabalho me fizeram conduzir as ações dos alunos.

Foi proposto aos alunos organizar cada um a sua pasta na aula, porque essa foi a primeira vez que participavam de uma atividade desse tipo, não tinham tido nenhum modelo anterior para seguir. Sendo assim, foi possível interpretar que esse momento iria trazer muitas dúvidas para os alunos se fosse feito como tarefa de casa.

Isso também aconteceu com Villas Boas, que explicita que em suas primeiras experiências com os alunos utilizando o portfólio ela direcionou tudo aos alunos.

Percebeu-se também certo desconforto dos alunos que tinham feito poucos registros e não dispunham de muito material para selecionar o que mais aprenderam ou não e inserir no portfólio. Eles perceberam quanto a prática de realizar registros era importante para o trabalho, pois se não fazem não têm dados para selecionar.

É importante levar em consideração que o aluno 12 (J.) tem dificuldade de manter a atenção nas aulas e faz poucos registros, talvez porque é um aluno adiantado nessa turma, ou seja, mais novo que os outros, e não está na 
mesma fase de desenvolvimento que os outros alunos. Preciso dar atenção mais individualizada a ele.

Mesmo admitindo erros e limitações, uma coisa consigo enxergar: mediante meus esforços a avaliação realizada tomava um novo rumo no processo de aprendizagem dos alunos e na minha prática pedagógica, uma vez que a prática do portfólio estava redimensionando o meu trabalho o tempo todo porque os registros me fazem refletir- atuar-refletir.

\section{Aula 8: Observações da professora sobre o portfólio dos alunos}

TABELA 8 - $\underline{\text { Resultados da primeira coleta do portfólio }}$

\begin{tabular}{|c|c|c|}
\hline Alunos & $\begin{array}{l}\text { Portfólio: } \\
\text { O que mais aprendeu? }\end{array}$ & $\begin{array}{l}\text { Portfólio: } \\
\text { O que mais sentiu dificuldades? }\end{array}$ \\
\hline 1 (A.B.) & $\begin{array}{l}\text { A aula "De onde surgiram os } \\
\text { jogos?" me ensinou que tem } \\
\text { que ter atenção e concentração. }\end{array}$ & $\begin{array}{l}\text { Entender o que é jogo. Participar } \\
\text { das discussões nas aulas. }\end{array}$ \\
\hline 2 (B.) & $\begin{array}{l}\text { Saber o que é jogo, conhecer } \\
\text { "melhor" o pique-bandeira. }\end{array}$ & $\begin{array}{l}\text { De onde surgiram os jogos, } \\
\text { prestar atenção na aula. }\end{array}$ \\
\hline $3(\mathrm{C})$. & $\begin{array}{l}\text { Jogos de correr, o cumprimento } \\
\text { de regras e a cooperação do } \\
\text { grupo. }\end{array}$ & Volear a peteca com mira. \\
\hline $4(\mathrm{~F})$. & $\begin{array}{l}\text { Achou interessante a hipótese } \\
\text { sobre a origem dos jogos e os } \\
\text { jogos de correr que possibilitaram } \\
\text { fazer estratégias. }\end{array}$ & $\begin{array}{l}\text { Foi difícil pesquisar com os pais, } \\
\text { pois foi difícil eles encontrarem } \\
\text { tempo para responder às perguntas. }\end{array}$ \\
\hline $5(\mathrm{~F})$. & $\begin{array}{l}\text { Peteca, os jogos de saltar e } \\
\text { saber de onde surgiram os } \\
\text { jogos. }\end{array}$ & $\begin{array}{l}\text { Nos jogos de correr quando } \\
\text { alguns colegas não davam } \\
\text { oportunidade para outras pessoas } \\
\text { fazer ponto. }\end{array}$ \\
\hline 6 (G.B.) & Os jogos de saltar. & $\begin{array}{l}\text { Entender as regras do pique- } \\
\text { bandeira. }\end{array}$ \\
\hline 7 (G.R.) & $\begin{array}{l}\text { O jogo do aumenta-aumenta, } \\
\text { pique-bandeira e barra-manteiga. }\end{array}$ & $\begin{array}{l}\text { Nos jogos pique-bandeira e } \\
\text { peteca porque lhe falta velocidade. }\end{array}$ \\
\hline
\end{tabular}




\begin{tabular}{|c|c|c|}
\hline 8 (G.) & $\begin{array}{l}\text { Saber de onde surgiram os } \\
\text { jogos e o que é jogo. }\end{array}$ & Pique-bandeira e saltar. \\
\hline 9 (I.C.) & $\begin{array}{l}\text { Respeitar as regras, saber } \\
\text { perder e ganhar. }\end{array}$ & Saltar. \\
\hline 10 (I.C.) & Jogo alerta. & $\begin{array}{l}\text { O jogo escolhido da pesquisa } \\
\text { com os pais: futebol e saltar. }\end{array}$ \\
\hline 11 (I.) & $\begin{array}{l}\text { Jogo pega-pega cocorô e } \\
\text { saber resolver problemas com } \\
\text { conversa. }\end{array}$ & No pula-sela. \\
\hline $12(\mathrm{~J})$. & $\begin{array}{l}\text { Fazer o diário, pois a ajudou a } \\
\text { ver o que aprendeu. }\end{array}$ & $\begin{array}{l}\text { Entender sobre o projeto Jogos } \\
\text { da Escola. }\end{array}$ \\
\hline 13 (J.) & $\begin{array}{l}\text { A pesquisa com os pais, } \\
\text { porque aprendeu um jogo que } \\
\text { não conhecia. }\end{array}$ & De onde surgiram os jogos. \\
\hline 14 (J.B.) & $\begin{array}{l}\text { Saber onde surgiram os jogos } \\
\text { e a saltar de diferentes maneiras. }\end{array}$ & Volear a peteca. \\
\hline 15 (J.P.) & Saltar de diferentes formas. & $\begin{array}{l}\text { Entender para que servem os } \\
\text { registros diários. }\end{array}$ \\
\hline $16(\mathrm{~K})$. & O novo jogo de alerta. & Volear a peteca. \\
\hline 17 (L.) & $\begin{array}{l}\text { Jogos de peteca, ter mais mira } \\
\text { e receber melhor. }\end{array}$ & Melhorar o saltar. \\
\hline 18 (L.) & $\begin{array}{l}\text { A pesquisa sobre os jogos dos } \\
\text { pais. }\end{array}$ & $\begin{array}{l}\text { Nos saltos, porque teve medo de } \\
\text { cair, e nos jogos com peteca. }\end{array}$ \\
\hline 19 (L.) & $\begin{array}{l}\text { Jogar peteca, porque aprendeu } \\
\text { algo que não conhecia. }\end{array}$ & $\begin{array}{l}\text { Entender as regras do pique- } \\
\text { bandeira. }\end{array}$ \\
\hline 20 (M.) & De onde surgiram os jogos. & Saltar. \\
\hline 21 (N.C.) & $\begin{array}{l}\text { Pesquisa com os pais. Os } \\
\text { jogos de peteca: aprendeu a } \\
\text { volear e mirar. }\end{array}$ & $\begin{array}{l}\text { Origem dos jogos. } \\
\text { Alguns jogos de correr. }\end{array}$ \\
\hline 22 (N.M.) & $\begin{array}{l}\text { Pesquisa com os pais. Gostou } \\
\text { de pesquisar sobre o jogo } \\
\text { pique-bandeira. }\end{array}$ & Volear a peteca. \\
\hline $23(\mathrm{~N})$. & Os jogos de correr. & No jogo alerta: saber lançar a \\
\hline
\end{tabular}


TABELA 9 - Primeira auto-avaliação e avaliação das aulas

\begin{tabular}{|c|c|c|}
\hline Alunos & $\begin{array}{l}\text { Auto-avaliação (Observações } \\
\text { gerais sobre o que os alunos } \\
\text { apontam com relação ao que } \\
\text { fazer para melhorar as suas } \\
\text { dificuldades) }\end{array}$ & $\begin{array}{l}\text { Avaliação das aulas (realizada } \\
\text { pelos alunos) }\end{array}$ \\
\hline 1 (A.B.) & $\begin{array}{l}\text { Melhorar na corrida. Precisa } \\
\text { pesquisar mais. }\end{array}$ & $\begin{array}{l}\text { Elogia: A professora que ensina } \\
\text { muitos jogos. } \\
\text { Sugere: Diminuir as brigas. }\end{array}$ \\
\hline 2 (B.) & $\begin{array}{l}\text { Peteca: precisa ter mais } \\
\text { velocidade para receber e } \\
\text { fazer os registros. }\end{array}$ & $\begin{array}{l}\text { Elogia: Os jogos que exigem } \\
\text { velocidade, reflexo. } \\
\text { Sugere: Futebol todo dia. }\end{array}$ \\
\hline $3(\mathrm{C})$. & $\begin{array}{l}\text { Melhorar o pega-pega e os } \\
\text { registros diários. }\end{array}$ & $\begin{array}{l}\text { Elogia: A motivação da } \\
\text { professora. } \\
\text { Sugere: Respeito àquele que } \\
\text { está falando. }\end{array}$ \\
\hline $4(\mathrm{~F})$. & $\begin{array}{llr}\text { Fazer } & \text { pesquisas, } & \text { saber } \\
\text { resolver } & \text { problemas } & \text { com } \\
\text { conversa. } & & \\
& & \end{array}$ & $\begin{array}{l}\text { Elogia: Jogo de correr. } \\
\text { Critica: Aulas teóricas, brigas entre } \\
\text { amigos. } \\
\text { Sugere: Menos aulas teóricas. }\end{array}$ \\
\hline $5(\mathrm{~F})$. & $\begin{array}{l}\text { Melhorar na defesa dos jogos } \\
\text { para ajudar o time a vencer }\end{array}$ & $\begin{array}{l}\text { Elogia: Quando o jogo dá certo. } \\
\text { Sugere: Mais participação e } \\
\text { cooperação. }\end{array}$ \\
\hline 6 (G.B.) & Pesquisar mais. & $\begin{array}{l}\text { Elogia: O respeito entre amigos. } \\
\text { Sugere: Fazer um jogo que } \\
\text { tivesse um pouco de cada coisa } \\
\text { dos jogos feitos nas últimas } \\
\text { aulas. }\end{array}$ \\
\hline
\end{tabular}




\begin{tabular}{|c|c|c|}
\hline 7 (G.R.) & $\begin{array}{l}\text { Lembrar de fazer os registros } \\
\text { diários. }\end{array}$ & $\begin{array}{l}\text { Elogia: Os jogos. } \\
\text { Sugere: Regras mais clara, mais } \\
\text { tempo para a aula. }\end{array}$ \\
\hline 8 (G.) & $\begin{array}{l}\text { Lembrar de fazer os registros } \\
\text { diários. Melhorar as habilidades } \\
\text { de saltar e volear. }\end{array}$ & $\begin{array}{l}\text { Elogia: As aulas de Educação } \\
\text { Física. } \\
\text { Sugere: Os alunos possam } \\
\text { escolher os jogos e diversificar } \\
\text { os materiais. }\end{array}$ \\
\hline 9 (I.C.) & $\begin{array}{l}\text { Melhorar as habilidades de } \\
\text { correr com mais velocidade, } \\
\text { saltar e volear. }\end{array}$ & $\begin{array}{l}\text { Elogia: Discussões na aula. } \\
\text { Critica: A falta de respeito às } \\
\text { regras. }\end{array}$ \\
\hline 10 (I.C.) & $\begin{array}{l}\text { Participar mais e prestar atenção } \\
\text { na aula. }\end{array}$ & $\begin{array}{l}\text { Elogia: Atenção e compreensão } \\
\text { da professora. } \\
\text { Sugere: Escolher os jogos da aula. }\end{array}$ \\
\hline 11 (I.) & $\begin{array}{l}\text { Mais impulso nos saltos, fazer } \\
\text { os registros. }\end{array}$ & $\begin{array}{l}\text { Elogia: A professora. } \\
\text { Sugere: Mais jogos. } \\
\text { Crítica: Amigos que não tinham } \\
\text { cuidado com os colegas no pula- } \\
\text { sela. }\end{array}$ \\
\hline $12(\mathrm{~J})$. & Fazer os registros e o portfólio. & $\begin{array}{l}\text { Elogia: Jogos de correr } \\
\text { Sugere: Mais Jogos de correr e } \\
\text { saltar. }\end{array}$ \\
\hline $13(\mathrm{~J})$. & $\begin{array}{l}\text { Lembrar de fazer os registros } \\
\text { diários. Melhorar a impulsão } \\
\text { no saltar e no volear. }\end{array}$ & $\begin{array}{l}\text { Elogia: Jogos de correr e com bola } \\
\text { Sugere: Diminuição das brigas, e } \\
\text { que todos cumpram com as } \\
\text { tarefas de casa. }\end{array}$ \\
\hline 14 (J.B.) & $\begin{array}{l}\text { Precisa fazer mais pesquisas } \\
\text { e melhorar o voleio. }\end{array}$ & $\begin{array}{l}\text { Elogia: Jogos. } \\
\text { Sugere: Mais respeito às regras. } \\
\text { Critica: Brigas. }\end{array}$ \\
\hline 15 (J.P.) & $\begin{array}{l}\text { Prestar mais atenção nas } \\
\text { aulas teóricas. }\end{array}$ & $\begin{array}{l}\text { Elogia: Respeito às regras. } \\
\text { Sugere: Ter mais cooperação. } \\
\text { Critica: Brigas. }\end{array}$ \\
\hline $16(\mathrm{~K})$. & Precisa fazer mais pesquisas & Elogia: $A$ professora porque \\
\hline
\end{tabular}




\begin{tabular}{|c|c|c|}
\hline & $\begin{array}{l}\text { e melhorar o cumprimento } \\
\text { das regras. }\end{array}$ & $\begin{array}{l}\text { ajuda e é legal. } \\
\text { Sugere: Mais futebol, pega-pega, } \\
\text { mais tempo de aula. }\end{array}$ \\
\hline 17 (L.) & $\begin{array}{l}\text { Diz que o mais achou } \\
\text { importante foi que fazendo os } \\
\text { registros percebia o quanto } \\
\text { aprendia. Mas precisa melhorar } \\
\text { a mira e não esquecer de } \\
\text { fazer os registros. }\end{array}$ & $\begin{array}{l}\text { Elogia: A forma como é feita as } \\
\text { aulas. } \\
\text { Sugere: Mais tempo e aprender } \\
\text { mais jogos. }\end{array}$ \\
\hline 18 (L.) & Melhorar o voleio. & $\begin{array}{l}\text { Elogia: Registros diários. } \\
\text { Sugere: Ter mais pesquisas. } \\
\text { Critica: Brigas }\end{array}$ \\
\hline 19 (L.) & $\begin{array}{l}\text { Ter mais velocidade e pesquisar } \\
\text { mais. }\end{array}$ & Não fez. \\
\hline 20 (M.) & $\begin{array}{l}\text { Melhorar o impulso, fazer os } \\
\text { registros diários e participar } \\
\text { das discussões. }\end{array}$ & $\begin{array}{l}\text { Elogia: Aulas práticas e teóricas. } \\
\text { Sugere: Mais tempo de aula e } \\
\text { conhecer mais jogos. }\end{array}$ \\
\hline 21(N.C.) & $\begin{array}{l}\text { Melhorar a participação das } \\
\text { discussões. }\end{array}$ & $\begin{array}{l}\text { Elogia: Aulas práticas } \\
\text { Sugere: Ter mais jogos infantis, } \\
\text { ex.: mamãe polenta } \\
\text { Critica: Aulas teóricas. }\end{array}$ \\
\hline 22 (N.M.) & $\begin{array}{l}\text { Melhorar o voleio, fazer os } \\
\text { registros diários. }\end{array}$ & Não fez. \\
\hline $23(\mathrm{~N})$. & $\begin{array}{l}\text { Pesquisar mais, fazer os } \\
\text { registros diários. }\end{array}$ & $\begin{array}{l}\text { Elogia: Jogos de saltar. } \\
\text { Sugere: Jogos menos demorados } \\
\text { e mais futebol. }\end{array}$ \\
\hline
\end{tabular}

$\mathrm{Na}$ avaliação das aulas, os dados que me chamaram a atenção são os 11 alunos que sugerem mais aulas práticas. Com relação às críticas, cinco alunos criticam os conflitos ocorridos em aulas, três citam a falta de respeito às regras combinadas e 11 assinalam aspectos voltados à organização das aulas, como, por exemplo, organização do tempo da aula, o excesso de aulas teóricas e a necessidade de mais participação dos alunos. 
Quanto aos elogios, quatro alunos assinalam a postura assumida pela professora de sempre estar à disposição para ajudá-los, e cinco alunos enaltecem a forma com que as aulas práticas e teóricas foram propostas e a prática dos registros. Esse último indício demonstra que, mesmo não gostando de aulas com estratégias teóricas, os alunos reconheceram o valor desse tipo de estratégia para o processo de aprendizagem.

\section{Aula 9: Diário da aula}

Hoje, logo que a professora entrou na sala de aula, solicitou o portfólio dos alunos, mas muitos não trouxeram e justificaram que esqueceram.

Foi combinado com os alunos que não trouxeram a pasta do portfólio trazê-la na próxima aula.

Após essa conversa, os alunos foram chamados para se sentar em roda e a professora foi questionando-os sobre o que haviam aprendido, quais as atividades que fizeram até agora.

Eu havia escrito em folhas de sulfite, em letras grandes, os temas trabalhados em cada aula no mês de março. Conforme os alunos respondiam às perguntas, eu colocava o tema escrito no chão, construindo um grande mapa conceitual que representava a ordem em que foi feita cada atividade prática ou teórica que fizeram naquele intervalo do projeto.

Essa atividade foi bastante construtiva, pois cada resposta dos alunos e tematização exposta pela professora era discutida e se estabeleciam relações de uma atividade com outra, e era ressaltada a importância de cada proposta.

Percebeu-se que a construção do mapa conceitual possibilitou aos alunos entender a seqüência e a importância de cada atividade proposta para melhorar seu processo de ensino e aprendizagem.

Após, esse momento, os alunos fizeram a atividade de auto-avaliação. Como era a primeira vez que faziam esse tipo de atividade, optou-se por fazê-la em sala com ajuda da professora. Os alunos leram e esclareceram suas dúvidas junto à professora. Os alunos começaram a atividade auto-avaliativa, e conforme iam tendo outras interrogações a professora se aproximava do(a) aluno(a) que se manifestava com dúvidas e o(a) ajudava de forma individual. 


\section{Aula 9: Observações da professora sobre os registros dos alunos}

Eu preciso observar os comentários sobre o registro que representa o que mais aprenderam e o outro, que representa o que mais sentiram dificuldade no portfólio.

Ao olhar os portfólios, fiquei surpresa ao ver que 15 alunos não haviam entregado e que os outros alunos, que entregaram, fizeram sem contemplar os critérios combinados na aula.

Percebo que quando os alunos fazem os registros de maneira incompleta ou simplesmente não trazem isso pode ser conseqüência da forma que as explicações estão sendo apresentadas aos alunos. É necessário tomar cuidado com a forma que se usa para explicar tarefas de casa, pois não se está atingindo a compreensão dos alunos. Muitos saem da aula sem entender ao certo o que deveriam fazer.

A comunicação entre professora e alunos precisava ser melhorada, ou seja, as explicações precisavam ser mais claras e adequadas às características dos alunos. A iniciativa que escolhi para melhorar esse problema foi escrever orientações individuais sobre o que precisavam melhorar nos registros inseridos em seu portfólio. Utilizava papeizinhos coloridos que eram grudados nos registros para chamar a atenção dos alunos sobre os critérios que estavam faltando e o que precisavam melhorar.

\section{Aula 10: Diário da aula}

Em sala a professora optou por apresentar um roteiro, escrevendo na lousa a seqüência do que eles deveriam me entregar e o que iria acontecer na quadra: retomada dos jogos do projeto.

$\mathrm{Na}$ quadra os alunos escolheram um dos jogos praticados até então e se organizaram no espaço que tinham para a aula.

Os alunos que não haviam entregado os comentários no portfólio ou os alunos para quem a professora havia colocado recadinhos para melhorarem os comentários em seus portfólios foram chamados um por vez pela professora para lerem junto e ouvir as explicações sobre o que deveriam fazer para entregar na próxima aula. Após a conversa, os alunos retornavam à prática dos jogos. Essa conversa durava pouco tempo e parecia ser compreendida como necessária pelos alunos. 
Adotar essa estratégia foi um ponto positivo, uma vez que se estabeleceu um acordo mais forte com os alunos.

Percebi, ao fornecer feedback individual a cada aluno, que necessitavam de ajuda no portfólio.

Estou preocupada com a quantidade de informações oferecidas nas últimas aulas teóricas:

primeira aula - seleção dos registros, auto-avaliação;

segunda aula - retomada dos jogos;

terceira aula - a conversa com os alunos que não fizeram portfólio etc.

Considero as duas primeiras aulas teóricas necessárias, pois os alunos não tinham noção de como proceder na coleta dos registros e na auto-avaliação Entendo essa dificuldade dos alunos como normal por ter sido a primeira vez que eles fizeram esse tipo de avaliação.

\section{Para a próxima aula:}

- jogo transformado;

- entrega do portfólio daqueles alunos que não haviam feito.

\section{Aula 10: Observações da professora}

Sinto falta de discutir com alguém da área as estratégias que tenho utilizado na prática do portfólio. Gostaria muito de dividir minhas dúvidas e tomar decisões em conjunto com alguém. Talvez isso diminuísse a minha ansiedade e as atitudes impensadas.

\section{Aula 11: Diário da aula}

A aula iniciou-se em sala com a professora recolhendo os portfólios dos alunos para quem havia solicitado alteração na aula anterior.

Havia alguns registros e atividades de auto-avaliação sem nome e a professora mostrou para os alunos para encontrar os titulares.

A folha de registro e os critérios de avaliação para os registros sobre a aula foram fornecidos ainda em sala.

Os alunos mostravam-se muito ansiosos, pois no cronograma fixado na sala de aula esta aula seria prática e na quadra. 
$\mathrm{Na}$ quadra, solicitei que os alunos parassem em frente a um esquema feito por mim. O objetivo era norteá-los sobre o que o grupo havia apontado que precisava melhorar no portfólio e o que as minhas observações em aula e nos portfólios dos alunos apontavam que necessitava ser melhorado.

Após a exposição dos elementos que os alunos e a professora consideraram que melhoraram e outros que precisavam melhorar, construímos uma lista de itens que poderiam melhorar as dificuldades do grupo, como segue:

Lista de itens:

O QUE FAZER PARA MELHORAR?

- Correr mais

- Saltar melhor

- Chutar com mais mira

- Aprender a rebater

- Aprender a receber melhor a bola ou peteca.

- Pesquisar mais

- Lembrar de fazer os registros

- Escrever o que sentiu dificuldade

\section{Próxima proposta: Transformar os jogos}

Correr: pique-bandeira, mãe da rua, pega-pega, barra-manteiga Saltar: quebra-canela, pula-mula, aumenta-aumenta Volear: peteca

O objetivo é diminuir as dificuldades e atingir os itens listados sobre o que fazer para melhorar.

\section{Observações:}

Considero que esse tipo de esquema norteia os alunos com relação ao trabalho, pois retoma os objetivos, define os itens que distinguem os avanços, as dificuldades e o que fazer para melhorar.

A partir dessa apresentação, foi proposta aos alunos a transformação de um dos jogos de correr: o pega-pega cocorô.

As regras desse jogo foram lembradas e se perguntou aos alunos o que poderiam sugerir para mudá-las. E foi sugerido que fossem mudadas as regras do agachar para ser salvo, substituindo-as por outra forma para ser salvo. 
6 (G.B.): O amigo pode correr e se for pego não agacha, fica de pé para ser salvo e fugir mais rápido.

Professora: Se for pego fica como?

8 (G.): Pode ficar parado com a mão para frente para ser salvo por algum amigo que ainda não foi pego.

12 (J.): Tem que tomar cuidado quando for bater na mão do amigo porque alguém pode passar no meio e machucar o braço.

8 (G.): E também quando bater na mão do amigo não bater muito forte para não machucar. (alunos)

Eu sintetizo como ficou o jogo, após as sugestões dadas pelos alunos.

Foi dado início ao jogo e observou-se, após certo tempo de prática, que alguns alunos não estavam se esforçando e se deixavam "pegar" com facilidade. $O$ jogo foi parado e a professora perguntou: Por que foi posto aquele esquema na parede?

6 (G.B.): Para a gente ver o que precisamos melhorar.

Professora: E qual é o item que estamos trabalhando nesse jogo?

6 (G.B.): Correr mais rápido.

A professora também ressalta o item que apareceu nos registros dos alunos, que expressava que queriam jogar mais na aula de Educação Física. Além disso, diz que tem alunos que não estão realizando os jogos de maneira apropriada, pois não se empenham e assim não melhorarão as dificuldades encontradas.

12 (J.): Mas tem poucos pegadores.

2 (B.): Acho que precisa de mais pegadores no jogo.

Professora questiona: Andar é igual a correr?

19 (L.): Para correr é necessário ter mais velocidade.

6 (G.B.): Ter distância para pegar velocidade e ter resistência.

8 (G.): Eu quero falar de um problema, tem pegadores que só corre atrás dos seus amigos.

Professora diz: Esse problema não pode mais se repetir, pois todos estão jogando e não só as pessoas que são amigas do pegador.

Enquanto os alunos apresentavam as suas opiniões, outros não prestavam atenção. A professora logo observa e diz que é necessário prestar mais atenção na aula. Lembra que muitos alunos escreveram que precisavam 
manter mais atenção nas discussões da aula e com essas atitudes não estão fazendo nada para melhorar.

A pergunta é retomada pela prof.: Correr é diferente de andar?

Um aluno pede para mostrar como se corre e como se anda. Após a sua demonstração,

10 (I.C.) diz: Correr é mais rápido e andar é mais devagar.

Vários alunos falam ao mesmo tempo: A diferença é que para correr tem que pôr velocidade.

12 (J.): Quando andamos, a gente não pula muito; quando corremos, pula um pouquinho.

Professora: É isso aí, prestem atenção, o que o 12 (J.) quer dizer é que a diferença entre andar e correr é que, quando andamos, apóia-se a ponta calcanhar no chão e há mais contato com solo; já no correr o corpo se desloca com mais velocidade, as pernas e braços se flexionam mais e os pés saem por alguns segundo do chão.

É proposto pela prof.: Vamos colocar mais pegadores neste jogo, assim como o 2 (B.) e o 12 (J.) sugeriram anteriormente?

Os alunos aceitam. O jogo prossegue com a inserção de mais pegadores.

Observou-se que os alunos que estavam se esforçando pouco participaram mais ativamente do jogo e o fato de aumentar o número de pegadores aumentou as possibilidades de exercitar a corrida com picos de velocidade.

No final da aula, a roda de conversa foi mais curta por conta das discussões feitas no decorrer da aula. No entanto, a professora expõe três perguntas para os alunos tentarem responder no registro dessa aula:

1. Como ensinaria um amigo a jogar esse jogo?

2. Quais as dicas para correr mais rápido?

3. Como resolveu os problemas que aconteceram com os amigos nessa aula?

Optou-se mudar as perguntas feitas como critério de avaliação para os registros. Essa foi mais uma estratégia aplicada para melhorar o problema detectado com relação à falta de compreensão dos alunos quanto às explicações fornecidas por mim. 


\section{Aula 11: Observações da professora sobre os registros dos alunos}

Percebi que os critérios de avaliação fornecidos aos alunos estavam com uma linguagem difícil para eles entenderem o que seria avaliado nos registros inseridos no portfólio.

A estratégia utilizada para melhorar esse problema foi procurar outra maneira de fornecer os critérios por meio de perguntas que os alunos pudessem responder, construindo seu registro de forma mais completa.

Tive a idéia de construir essas perguntas atrelando-as ao objetivo que tinha para atingir como empreendimento final no projeto, que se relaciona à construção de um livro de jogos para presentear a um amigo. Desse modo, as perguntas ficaram da seguinte maneira:

1- Como você ensinaria a um amigo o jogo...?

2- Quando você e seus amigos estavam jogando..., você sentiu alguma dificuldade?

3- Qual foi essa dificuldade?

4- O que você fez, ou é possível ser feito, para melhorar a dificuldade?

5- Durante o jogo... aconteceu algum problema e de que forma você e o grupo resolveram?

TABELA 10 - Aula 11 - Observações da professora

\begin{tabular}{|l|l|}
\hline 1 (A.B.) & $\begin{array}{l}\text { Nós transformamos o jogo pega-pega } \\
\text { cocorô em mão para frente. } \\
\text { Expõe como jogou, por meio de } \\
\text { história em quadrinhos; coloca o } \\
\text { fugitivo sendo pego pelo pegador e } \\
\text { ficando com a mão para frente depois } \\
\text { que é pego. }\end{array}$ \\
\hline 2 (B.) & $\begin{array}{l}\text { Descreve como ficou o jogo } \\
\text { transformado. } \\
\text { Expõe que para jogar bem o jogo } \\
\text { proposto era preciso: Fugir correndo } \\
\text { com velocidade para não ser pego. } \\
\text { Diz como jogou. }\end{array}$ \\
\hline 3 (C.)
\end{tabular}




\begin{tabular}{|l|l|}
\hline 4 (F.) & Não fez. \\
\hline 5 (F.) & $\begin{array}{l}\text { Descreve como ficou o jogo } \\
\text { transformado. } \\
\text { Expõe as dicas: O objetivo era correr } \\
\text { ena brincadeira tinha 2 pegadores, aí } \\
\text { ficou muito fácil, então [foram } \\
\text { inseridos mais pegadores] tiveram } \\
\text { muitos pegadores e aí todo mundo } \\
\text { correu bastante. }\end{array}$ \\
\hline 6 (G.B.) & $\begin{array}{l}\text { Descreve como ficou o jogo } \\
\text { transformado. } \\
\text { Expõe as diferenças pontuadas na } \\
\text { aula com relação a correr e andar. } \\
\text { Explicita que com esse jogo pode-se } \\
\text { melhorar a velocidade na corrida. }\end{array}$ \\
\hline 7 (G.R.) & $\begin{array}{l}\text { Descreve como ficou o jogo } \\
\text { transformado. } \\
\text { Expõe que: Para jogar bem tinha que } \\
\text { não ficar parado, correr com velocidade } \\
\text { para não ser pego. }\end{array}$ \\
\hline 10 (I.C.) & $\begin{array}{l}\text { Descreve como jogou. } \\
\text { Expõe que: Tinha que correr com } \\
\text { velocidade para jogar bem esse jogo. } \\
\text { Aponta que o problema do jogo foi } \\
\text { resolvido após colocar mais pegadores } \\
\text { no jogo. }\end{array}$ \\
\hline $\begin{array}{l}\text { Descreve como ficou o jogo } \\
\text { transformado. }\end{array}$ \\
Não fez. \\
\hline
\end{tabular}




\begin{tabular}{|c|c|}
\hline 11 (I.C.) & $\begin{array}{l}\text { Descreve como jogou. } \\
\text { Expõe um problema: Eu vi gente que } \\
\text { andava ao invés de correr se } \\
\text { continuar assim não vou ser pega } \\
\text { nunca. } \\
\text { As dicas que usou para melhorar as } \\
\text { suas dificuldades: Não ficar parado, } \\
\text { correr com velocidade para não ser } \\
\text { pego. Desenha a posição em que o } \\
\text { fugitivo foi pego num determinado } \\
\text { momento do jogo. }\end{array}$ \\
\hline 12 (J.) & $\begin{array}{l}\text { Descreve como ficou o jogo } \\
\text { transformado. } \\
\text { Expõe as dicas: Não podia ficar } \\
\text { parado, correr pondo bastante } \\
\text { velocidade. Também apontou as } \\
\text { diferenças pontuadas na aula quanto } \\
\text { a correr e andar. }\end{array}$ \\
\hline $13(\mathrm{~J})$. & Não fez. \\
\hline 14 (J.B.) & $\begin{array}{l}\text { Descreve como ficou o jogo } \\
\text { transformado. } \\
\text { Expõe que: Tinha que se esforçar } \\
\text { para não ficar parado e correr bem } \\
\text { rápido. }\end{array}$ \\
\hline 15 (J.P.) & $\begin{array}{l}\text { Descreve como ficou o jogo } \\
\text { transformado. } \\
\text { Expõe que aprendeu nesta aula que } \\
\text { quando corremos fazemos pequenos } \\
\text { saltitos e por velocidade, por isso é } \\
\text { diferente de andar. } \\
\text { Aponta que o problema desse jogo é } \\
\text { que tinha que ter mais pegador } \\
\text { porque tinha gente que não corria. }\end{array}$ \\
\hline
\end{tabular}




\begin{tabular}{|l|l|}
\hline 16 (K.) & $\begin{array}{l}\text { Descreve como ficou o jogo } \\
\text { transformado. }\end{array}$ \\
\hline 17 (L.) & Braço quebrado. \\
\hline 18 (L.) & $\begin{array}{l}\text { Descreve como ficou o jogo } \\
\text { transformado. } \\
\text { Expõe as dicas que usou para } \\
\text { melhorar suas dificuldades no jogo: } \\
\text { Correr rápido, também foram } \\
\text { colocados mais pegadores no jogo. }\end{array}$ \\
\hline 19 (L.) & $\begin{array}{l}\text { Expõe: Resolvi os problemas } \\
\text { conversando com os amigos que não } \\
\text { cumpriam com as regras e também foi } \\
\text { colocado mais pegadores no jogo. }\end{array}$ \\
\hline 20 (M.) & $\begin{array}{l}\text { Descreve como ficou o jogo } \\
\text { transformado. } \\
\text { Expõe as dicas que usou para jogar e } \\
\text { melhorar suas dificuldades: Correr } \\
\text { rápido. }\end{array}$ \\
\hline 21 (N.C.) & $\begin{array}{l}\text { Descreve como ficou o jogo } \\
\text { transformado. } \\
\text { Aponta que o problema de desrespeito } \\
\text { às regras, por parte de alguns } \\
\text { colegas, foi resolvido por meio da } \\
\text { conversa e a inserção de mais } \\
\text { pegadores no jogo. }\end{array}$ \\
\hline $\begin{array}{l}\text { Descreve como ficou o jogo } \\
\text { transformado. } \\
\text { Expõe que: Quando algum amigo não } \\
\text { respeitava as regras eu tentava } \\
\text { conversar com ele porque isso } \\
\text { atrapalhava o jogo } \\
\text { Eu não consegui fazer o registro } \\
\text { porque nãolembrava de nada da aula. }\end{array}$ \\
\hline 23
\end{tabular}


Notou-se que os registros demonstraram que muitos não contemplaram os critérios expostos no painel da sala de aula.

Optou-se por colocar bilhetinhos coloridos sinalizando o que faltou nos registros dos alunos que não contemplavam os critérios preestabelecidos.

A idéia para a próxima aula é fazer um registro coletivamente com os alunos. Percebo que Ihes faltam modelos, por isso nos registros faltam tantos itens.

\section{Aula 12: Diário da aula}

Em sala foi solicitado o registro do dia 13/4/2007, mas alguns alunos não fizeram. Os alunos que não traziam a lição de casa na data combinada eram chamados para conversar com a professora e era permitido trazer o registro na próxima aula.

$\mathrm{Na}$ quadra, a aula foi iniciada com a proposta de testar um jogo variação do pique-bandeira que a aluna 21 (N.M.) pesquisou e inseriu em seu registro.

Foi exposto qual era o objetivo do jogo e foi relembrado o que estavam buscando que era melhorar esse jogo de acordo com o quadro apresentado na última aula, que continuava fixado no local da aula.

O jogo começou e percebeu-se que alguns alunos não estavam praticando a habilidade de correr com velocidade por que havia apenas um pegador e o espaço era bastante amplo, portanto estava fácil fugir. (aluno)

Optou-se por parar o jogo e perguntar o que se buscava melhorar com esse jogo.

Os alunos responderam: Melhorar a corrida com velocidade.

Professora perguntou: Do jeito que o jogo salve a bandeira está sendo praticado (andando), vocês acham que é possível melhorar esse objetivo que vocês pontuaram que precisa melhorar?

Alunos respondem: Não.

Professora perguntou: Então o que vocês sugerem ser feito nesse jogo para que o objetivo de correr mais rápido possa ser contemplado?

6 (G.B.): É necessário mais gente para pegar.

11 (I.C.): Eu também concordo que precisa de mais pegadores porque só o 13 (J.) não está dando conta.

6 (G.B.) expõe uma idéia: Com mais pegadores dá para deixar um correndo ao redor do círculo para vigiar os que foram pegos. 
É decidido pela prof. que iriam testar o jogo com quatro, sendo dois meninos e duas meninas que se apresentaram como interessados para cumprirem com 0 papel de pegador voluntariamente.

A participação e a motivação dos alunos aumentam consideravelmente com a inserção dos pegadores, ao mesmo tempo em que a prática de deslocamentos de corridas e desvios passou a ser executada de forma mais veloz.

Depois de algum tempo jogando, percebe-se que os alunos que eram pegos ficavam muito tempo na área determinada para eles sem serem salvos.

Mais uma vez a professora pára o jogo e expõe sua observação. Pergunta 0 que podem fazer para que os colegas possam ser salvos mais rapidamente.

Os alunos respondem: Salvar o amigo mais rápido e se preocupar com quem precisa de ajuda. (aluno)

Professora pergunta: Porque é importante salvar mais rápido o amigo?

6 (G.B.): Para que ele tenha oportunidade de correr mais e melhorar.

Professora: Quais as dicas que vocês dariam a um amigo para que ele possa melhorar neste jogo?

11 (I.C.): Prestar atenção se o pegador está perto ou longe.

15 (J.P.): Correr rápido saltando.

Professora: Por que saltando?

15 (J.P.): Não é saltando, eu quis dizer que quando corremos rápido fazemos alguns saltitos.

Professora: O que a 15 (J.P.) disse é verdade, como vimos na discussão da última aula, quando corremos executamos pequenos saltitos.

3 (C.): Um amigo meu corre todos os dias, ele me disse que para correr rápido precisa mexer os braços.

Professora: Seu amigo tem razão, mas como os braços se mexem durante uma corrida?

6 (G.B.): Tem que ser braço contrário da perna, não pode ser o mesmo braço da perna senão fica difícil correr.

A forma com que o trabalho estava sendo conduzido instigava os alunos a procurarem cada vez mais entender conceitos sobre o que, como e por que estavam aprendendo aqueles conteúdos. Percebeu-se que alguns conceitos, sendo assim, eles ajudavam a ensinar aos outros alunos. Era possível observar 
que a linguagem do colega aproximava-se da compreensão do amigo, auxiliando-o a aprender mais.

Notou-se também que a mediação da professora foi fundamental nesse momento: eles não sabiam se estavam certos e a síntese das informações expostas por ela assessorava os alunos nesse processo.

Percebeu-se que o aluno 7 (G.R.) era pego toda hora. A professora, preocupada com a participação do aluno, uma vez que ele foi um dos que ressaltaram em seus registros a necessidade de melhorar a corrida com velocidade em jogos de perseguição, chama-o e questiona o que achava que precisava fazer para não ser pego.

7 (G.R.): Correr mais rápido, não ficar parado e pôr mais velocidade quando o pegador vier me pegar.

A professora então ressalta que ele precisa tentar colocar o que diz na prática do jogo, pois é só praticando que irá melhorar. O aluno concorda e promete se esforçar mais. O aluno voltou a jogar.

Outra estratégia tomada quanto o aluno 7 (G.R.) foi colocá-lo como pegador. $O$ aluno demonstrou um grande esforço para perseguir e pegar os amigos, cumprindo assim com o objetivo traçado na aula.

No final da aula a professora solicitou que todos se sentassem na frente do cartaz e perguntou se com o jogo executado estavam atingindo as metas: melhorar a corrida com velocidade, prestar mais atenção, melhorar a participação na aula, inclusive nas discussões do grupo. Os alunos mostravamse, nesse momento, atentos e preocupados.

Expus os critérios que deveriam ser cumpridos no registro daquela aula.

Quando expôs o segundo critério de avaliação, apresentado por meio de questão: Quais foram as habilidades exigidas no jogo e quais as dicas mais importantes para realizá-las?

Os alunos se motivaram a reponder:

12 (J.): É necessário ter habilidade motora.

20 (M.): Ter resistência física e pôr velocidade.

4 (F.): Correr dando pequenos saltitos.

Professora: $O$ que mais precisa fazer para executar bem as habilidades exigidas no jogo?

13 (J.): Uutilizar os braços. 
16 (K.): Utilizar os braços com coordenação.

Professora: Como é utilizar os braços com coordenação?

Os alunos ficam quietos e pensativos.

Eu solicito aos alunos que se levantem da roda e corram com o mesmo braço e mesma perna. Os alunos executam e se manifestam, dizendo que é difícil correr dessa maneira e que com o braço contrário da perna é mais fácil.

Após escutar os alunos, digo: Então como ficam os braços na corrida?

20 (M.): Contrário da perna.

Eu contemplo a resposta do aluno, dizendo: É isso mesmo, e é essa coordenação que o 16 (K.) falou anteriormente.

19 (L.): Eu quero falar de outra coisa, eu vi no jogo que os pegadores conseguiam pegar muitos fugitivos, mas os fugitivos não conseguiam salvar muitos colegas pegos.

(alunos)

Professora: Vocês sabem o que isso significa? É o que discutimos durante o jogo, precisa melhorar a corrida para jogar cada vez melhor, ou seja, para pegar, fugir e salvar mais rápido os colegas.

8 (G.): Eu acho que uma outra coisa também tinha que melhorar neste, quando alguém era salvo o pegador já ia pegá-lo de novo.

Eu paro e penso, para responder: Se o que se observou no jogo foi a necessidade de melhorar a corrida com velocidade, tanto do pegador quanto do fugitivo, se o pegador pega muito rápido quem é salvo, será que essa pessoa não precisa se esforçar para correr mais rápido e ficar mais atenta no jogo?

8 (G.): É mesmo.

7 (G.R.): Um outro problema que ninguém falou é que tinha pegadores que estavam entrando no círculo onde os fugitivos pegos deveriam ficar.

Professora: De acordo com a regra, o que o 7 (G.R.) falou vale?

Os alunos falam que não. Eu digo que quem estava agindo dessa forma estava desrespeitando a regra do jogo.

\section{Aula 12: Observações da professora sobre os registros dos alunos}

Critérios de avaliação (observar se os alunos citam respostas coerentes com o que foi trabalhado em aula): 


\section{Explica como se joga?}

2. Pontua as regras e as habilidades envolvidas no jogo e as dicas para melhorar?

3. Cita os problemas encontrados e como foram resolvidos ou não?

4. Insere outras formas de linguagem para registrar ou outros materiais para complementar o seu registro?

TABELA 11 - Aula 12 - Observações da professora

\begin{tabular}{|l|l|}
\hline 1 (A.B.) & $\begin{array}{l}\text { Expõe que: Como tinham poucos } \\
\text { pegadores no jogo isso foi resolvido } \\
\text { colocando mais pegadores, e o jogo } \\
\text { ficou mais legal. }\end{array}$ \\
\hline 2 (B.) & $\begin{array}{l}\text { Explica como se joga. } \\
\text { Utiliza-se do desenho para explicitar o } \\
\text { item anterior. }\end{array}$ \\
\hline 3 (C.) & $\begin{array}{l}\text { Explica como se joga. } \\
\text { A dica que dá é correr o mais rápido } \\
\text { que pode. }\end{array}$ \\
\hline 4 (F.) & $\begin{array}{l}\text { Explica como se joga. } \\
\text { Diz que sentiu dificuldade algumas } \\
\text { vezes, pois foi pego por falta de } \\
\text { velocidade. }\end{array}$ \\
\hline 5 (F.) & $\begin{array}{l}\text { Explica como se joga. } \\
\text { Explicita que o problema do jogo } \\
\text { foram pessoas que ficavam andando } \\
\text { e não se esforçavam para fugir do } \\
\text { pegador. }\end{array}$ \\
\hline 6 (G.B.) & $\begin{array}{l}\text { Explica com muitos detalhes como se } \\
\text { joga. } \\
\text { Explicita que o jogo ensina a correr } \\
\text { colocando o máximo de velocidade } \\
\text { Obs.: Menciona que nessa aula } \\
\text { aprendeu o que fazer para correr mais }\end{array}$ \\
\hline
\end{tabular}




\begin{tabular}{|c|c|}
\hline & rápido num jogo de perseguição. \\
\hline 7 (G.R.) & $\begin{array}{l}\text { Explicita os problemas: No início do } \\
\text { jogo só havia um pegador, o jogo } \\
\text { melhorou depois que foram colocados } \\
\text { quatro pegadores. Tinha um pegador } \\
\text { que entrava no círculo dos alunos } \\
\text { pegos. } \\
\text { E diz: Junto a professora conversamos } \\
\text { para deixar claro que isso não valia. }\end{array}$ \\
\hline 8 (G.) & $\begin{array}{l}\text { Foram colocados mais pegadores } \\
\text { para correr mais no jogo. }\end{array}$ \\
\hline 9 (I.) & Explica como se joga. \\
\hline 10 (I.C.) & $\begin{array}{l}\text { Explicita todas as dicas que foram } \\
\text { discutidas na aula, como velocidade } \\
\text { para pegar, fugir e salvar os amigos. } \\
\text { E expõe que o jogo melhorou depois } \\
\text { se colocou mais quatro pegadores. }\end{array}$ \\
\hline 11 (I.C.) & Explica como se joga. \\
\hline 12 (J.) & Não fez. \\
\hline $13(\mathrm{~J})$. & $\begin{array}{l}\text { Explica com muitos detalhes como se } \\
\text { joga, utilizando-se do desenho. }\end{array}$ \\
\hline 14 (J.B.) & $\begin{array}{l}\text { Explica com muitos detalhes como se } \\
\text { joga. } \\
\text { Expõe que colocaram mais pegadores } \\
\text { para correrem mais no jogo. } \\
\text { Mostrou o registro melhorado, baseando- } \\
\text { se nos apontamentos feitos pela } \\
\text { professora nesse registro. }\end{array}$ \\
\hline 15 (J.P.) & Explica como se joga. \\
\hline $16(\mathrm{~K})$. & $\begin{array}{l}\text { As dicas para jogar bem esse jogo } \\
\text { são: Correr bastante, ter reflexo e fugir } \\
\text { do pegador dando olé [se desviando]. } \\
\text { Expõe: Um pegador era pouco para }\end{array}$ \\
\hline
\end{tabular}




\begin{tabular}{|l|l|}
\hline 17 (L.) & $\begin{array}{l}\text { participar mais e correr mais, quando } \\
\text { colocamos mais 4 pegadores resolvemos } \\
\text { este problema. }\end{array}$ \\
\hline 18 (L.) & $\begin{array}{l}\text { Uma dica importante é ter velocidade } \\
\text { na hora de salvar o amigo. }\end{array}$ \\
\hline 19 (L.) & $\begin{array}{l}\text { Explicita dois problemas: Tinha só um } \\
\text { pegador e o jogo melhorou depois se } \\
\text { colocou quatro pegadores; tinha um } \\
\text { pegador que entrava no círculo dos } \\
\text { alunos pegos. }\end{array}$ \\
\hline 20 (M.) & $\begin{array}{l}\text { Não fez. } \\
\text { Explica como se joga. }\end{array}$ \\
\hline 21 (N.M.) & $\begin{array}{l}\text { Expõe todas as dicas que foram } \\
\text { discutidas na aula: velocidade para } \\
\text { pegar, fugir e salvar os amigos. } \\
\text { Cita: Achei importante tentar resolver } \\
\text { os problemas com os amigos usando } \\
\text { a conversa sem ajuda da professora. }\end{array}$ \\
\hline 22 (N.C.) & $\begin{array}{l}\text { Explica com muitos detalhes como se } \\
\text { joga. Explicita o problema: No início } \\
\text { do jogo havia apenas um pegador, } \\
\text { então a gente não corria muito. O jogo } \\
\text { melhorou que colocou quatro pegadores. } \\
\text { Utiliza-se do desenho. }\end{array}$ \\
Não fez. \\
\hline
\end{tabular}

Nota-se que os alunos têm se empenhado mais na produção dos registros. Considero, de maneira geral, que os fatores que contribuem para isso são: (1) já se acostumaram a fazer os registros como tarefas de casa; (2) os critérios de avaliação expostos aos alunos estão mais simplificados e aproximam-se da linguagem deles; (3) compreenderam que a utilização de outras formas de linguagem diminui $o$ trabalho de escrever e possibilita a expressão da criatividade; (4) as propostas das aulas práticas mostram-se significativas para os alunos. 


\section{Aula 12: Reunião com a coordenadora do Ensino Fundamental}

As considerações finais dos assuntos debatidos na reunião:

- Fazer a avaliação referente às observações da professora em outro dia ou fora do horário de aulas. Por exemplo: quem for terminando a prova da professora de sala vem conversar com a professora de Educação Física;

- Ou fazer a avaliação referente às observações da professora no horário do intervalo, somente com os alunos que realmente precisam;

- Sobre a nota, argumentar com os alunos que atribuíram nota muito aquém do que demonstraram no decorrer do processo de ensino e aprendizagem que aquela nota não é justa, comparando-as com as anotações de observação da professora;

- Não fazer tabelas de verificação de competência, para evitar uma quantidade muito grande de avaliações.

\section{Aula 13: Diário da aula}

Nessa aula os diários foram recolhidos em sala, foi fornecida aos alunos a folha para o próximo registro e eles foram à quadra.

$\mathrm{Na}$ quadra, com o objetivo de chamar a atenção dos alunos sobre como fazer os registros, dei a cada um os registros referentes à aula de 13/4/2007 com bilhetinhos contendo o que estava faltando, de acordo com os critérios apresentados, para que pudessem conscientizar-se sobre o que não haviam contemplado em seu registro. Essa atitude foi tomada porque havia alunos que ainda não compreendiam a necessidade de cumprir com todos os critérios preestabelecidos na aula, outros não sabiam como registrar alguns critérios e determinados alunos demonstravam falta de vontade para fazer seu registro da forma que deveria ser.

Após os alunos lerem meus apontamentos em seu registro, a estratégia escolhida foi fazer coletivamente esse registro, contemplando os critérios combinados na aula e eu atuando como escriba. A intenção era fornecer aos alunos sugestões sobre como fazer um registro de forma escrita, desenhada e com colagem de figuras pesquisadas em livros e revistas.

Sentei em roda junto aos alunos e relembrei os critérios utilizando o mesmo cartaz exposto na sala de aula. Disse aos alunos que observei nos registros da 
turma a falta de os critérios de avaliação serem contemplados, pois uns explicam como se joga o jogo proposto mas não registram as dicas importantes que aprenderam sobre o jogo e as habilidades que exige. Por outro lado, tem alunos que registram problemas, mas não registram como estes foram resolvidos ou se tentaram resolver os problemas encontrados. Foi ressaltado aos alunos que tudo o que faltou em seu registro está especificado nos bilhetinhos anexados e aqueles que desejarem poderão melhorar e trazer para eu ver novamente. (alunos)

A construção do registro coletivo iniciou-se com as seguintes questões norteadoras:

Professora: $O$ que precisamos fazer para obter um bom registro? Primeiro precisa recorrer à folha com os critérios de avaliação oferecidos pela professora para fazer o registro dessa aula.

Professora: Qual foi o objetivo dessa aula?

Professora: Como se joga o jogo que vocês transformaram nessa aula?

Professora: Quais foram às dificuldades encontradas?

Professora: Quais as dicas para melhorar e jogar e bem esse jogo?

Professora: Quais os problemas aconteceram? Como foram resolvidos? Ou se tentou resolver?

A cada pergunta a professora escrevia o que os alunos respondiam. Quando terminou de escrever, leu para os alunos, para verem como ficou.

A proposta seguinte foi o desenho no qual foi enfatizada a importância de deixar claro no desenho quem era o pegador e o fugitivo. Com relação a como se joga, foram inseridas setas para mostrar o deslocamento dos jogadores na área do jogo em situação de ataque e defesa.

Outra proposta foi fazer o registro através de história em quadrinhos. A professora pedia a opinião dos alunos e ia registrando de acordo com as sugestões deles.

Depois, a professora mostrou aos alunos como fazer uma pesquisa estabelecendo relação com o que foi ensinado. Na pesquisa trazida havia figuras que tinham conexão com o que aprenderam naquela aula. (alunos) No segundo momento da aula, os alunos e a professora foram para o centro da quadra e foi proposto que eles sugerissem variações para jogar pique- 
bandeira, já que muitos haviam registrado na auto-avaliação que sentiam dificuldade nesse jogo.

A primeira regra transformada foi a de realizar o jogo com menos gente.

18 (L.) sugere: Vamos fazer com quatro times.

6 (G.B.): Vamos dividir a quadra em três partes, aí dá três jogos.

Sendo assim, a quadra foi dividida em três partes, os 23 alunos foram divididos em seis equipes e o jogo começou.

Conversei em particular com o aluno 13 (J.) e o 16 (K.), que estavam fora do jogo por ficarem importunando os colegas e não prestarem atenção na aula.

A professora explicou aos alunos acima por que eles foram retirados da aula: 1) na construção do registro eles não ajudaram, só atrapalharam com brincadeiras fora de hora; 2) 16 (K.) estava chutando os amigos; 3) 13 (J.) não prestava atenção no momento da construção do registro, e outro problema é que ele não trouxe o registro referente à última aula.

Durante o jogo foi possível perceber que o aluno 7 (G.R.) se esforçou bastante. Ele demonstrou que estava se empenhando mais na corrida e tentou várias vezes fazer o ponto.

Depois de alguns minutos de jogo, o aluno 13 (J.) e o 16 (K.) foram chamados pela professora, que disse a eles que iria dar uma nova chance, mas eles precisavam melhorar o seu comportamento na aula, bem como a atenção em todos os momentos da aula.

O aluno 16 (K.) foi lembrado de que tem realizado bons registros e quando quer contribui muito nas discussões da aula. A professora enfatiza que sabe que ele é um bom aluno.

Os alunos voltaram a jogar.

O 16 (K.) pedia o tempo todo para eu resolver os problemas que encontrava. $\mathrm{Na}$ segunda vez em que o aluno fez isso, eu disse que não iria resolver seus problemas e que era necessário ele procurar fazer alguma coisa para resolvêlos sozinho. Sugiro: Que tal você pedir tempo para o grupo e expor o problema para ser resolvido no próprio grupo? (aluno)

\section{Na roda de conversa:}

A professora lembrou que eles precisavam fazer o registro referente ao que aprenderam ou não na aula. 
Eu e os alunos combinamos que, como fizemos o registro-modelo de forma coletiva, podia usá-lo como padrão para completar o que faltava no registro entregue com bilhetinho feito pela professora aos alunos. A professora disse aos alunos que iria deixar o registro coletivo fixado no painel da sala de aula para que pudessem consultá-lo toda vez que precisassem.

Eu pergunto aos alunos o que poderiam apontar no registro da aula de hoje: Qual foi o jogo? O que transformaram nele? Por quê?

12 (J.) disse que a aluna 15 (J.P.) não respeitou a regra de que era sua vez de pegar a bola.

15 (J.P.) responde: Eu peguei porque o jogo estava parado, havia pedido "tempo" para conversar.

Professora: Então está explicado, mas ainda sugiro que, quando for pedir "tempo", falar bem alto para todos ouvirem e participarem da conversa.

16 (K.) disse que tinha gente que não cumpria com as regras.

Professora diz: E lembrei um ponto que precisava ser melhorado, é resolver os problemas que aconteceram no decorrer do próprio jogo.

Perguntei aos alunos o que deveriam fazer quando acontecesse um problema. Os alunos respondem: Pedir tempo e conversar com os colegas.

Eu digo: É isso mesmo, tem que conversar e até chegar num acordo dentro da própria equipe, mas para que isso aconteça é necessário saber ouvir e falar no grupo.

3 (C.): No jogo eu também percebi que o 2 (B.) era do time adversário e não cumpria com as regras. (alunos)

Professora questiona: Mas você conversou isso com o amigo?

3 (C.): Sim, mas ele fazia que não escutava.

Professora: Então é necessário parar o jogo, conversar novamente, e se o colega continuar com as mesmas atitudes, o que vocês acham que poderia acontecer com ele?

3 (C.): Ele deve ser retirado do jogo.

Eu finalizo a aula, dizendo que não adianta tentar resolver os problemas somente quando sentarmos no final da aula na roda de conversa; é necessário resolver os problemas encontrados no jogo ou com os amigos durante a prática dos jogos e no momento em que acontecem. 


\section{Aula 13: Observações da professora sobre os registros dos alunos}

Critérios de avaliação (observar se os alunos citam respostas coerentes com o que foi trabalhado em aula):

1. Identifica as atividades e o jogo realizados em aula?

2. Pontua as regras e as habilidades envolvidas no jogo e as dicas para melhorar?

3. Cita os problemas encontrados e como foram resolvidos ou não?

4. Insere outras formas de linguagem para registrar ou outros materiais para complementar o seu registro?

TABELA 12 - Aula 13 - Observações da professora

\begin{tabular}{|l|l|}
\hline 1 (A.B.) & \begin{tabular}{l} 
Identifica o jogo realizado e cita que a \\
professora ensinou como fazer o \\
registro diário de Educação Física. \\
Expõe que as dicas mais importantes \\
que aprendeu nessa aula foram: \\
prestar mais atenção na aula e não \\
olhar para os problemas que acontecem \\
entre os jogadores da outra equipe. \\
Disse que o jogo ficou mais fácil \\
sendo jogado com menos pessoas. \\
Também cita que fazer o registro de \\
maneira coletiva foi bom para quem \\
tinha dúvidas. \\
Utilizou o desenho para explicar como \\
jogou. \\
\hline 3 (B.)
\end{tabular} \mid \begin{tabular}{l} 
Cita somente como jogou. \\
\hline (C.) \\
Disse que construíram com a \\
professora um registro para tirar \\
dúvidas de quem não sabe fazer. \\
ficaram fora da aula porque não
\end{tabular} \\
\hline
\end{tabular}




\begin{tabular}{|c|c|}
\hline & $\begin{array}{l}\text { prestavam atenção. Cita outros } \\
\text { problemas: pessoas que não } \\
\text { aceitavam as regras do jogo, e um } \\
\text { momento em que caiu mas se } \\
\text { recuperou rápido. } \\
\text { Faz um registro muito criativo. }\end{array}$ \\
\hline $4(\mathrm{~F})$. & Não fez. \\
\hline $5(\mathrm{~F})$. & $\begin{array}{l}\text { Diz que falamos como fazer os } \\
\text { registros diários e jogaram pique- } \\
\text { bandeira. } \\
\text { Expõe: A gente não teve nenhum } \\
\text { problema de brigas hoje, porque } \\
\text { jogamos em } 3 \text { campos e com menos } \\
\text { jogadores. }\end{array}$ \\
\hline 6 (G.B.) & Não fez. \\
\hline 7 (G.R.) & Não fez. \\
\hline $8(\mathrm{G})$. & $\begin{array}{l}\text { Cita que foi falado na aula como se } \\
\text { devem fazer os registros diários e que } \\
\text { jogaram pique-bandeira. }\end{array}$ \\
\hline 9 (I.) & $\begin{array}{l}\text { Cita: Jogamos pique-bandeira. } \\
\text { Explicita com se joga. }\end{array}$ \\
\hline 10 (I.C.) & $\begin{array}{l}\text { Cita que nessa aula foi falado como } \\
\text { se devem fazer os registros diários e } \\
\text { que jogaram pique-bandeira. } \\
\text { Problema identificado: Tinham pessoas } \\
\text { que não aceitavam que eram pegas. A } \\
\text { gente conversou e entrou num acordo } \\
\text { com o grupo após pedirem tempo no } \\
\text { jogo para resolver este problema. }\end{array}$ \\
\hline 11 (I.C.) & $\begin{array}{l}\text { Fez um registro criativo e explicou } \\
\text { com detalhes como jogou, utilizando a } \\
\text { escrita e o desenho. }\end{array}$ \\
\hline 12 (J.) & Não fez. \\
\hline
\end{tabular}




\begin{tabular}{|c|c|}
\hline $13(\mathrm{~J})$. & $\begin{array}{l}\text { Usa o desenho e a escrita para } \\
\text { explicar como jogou. }\end{array}$ \\
\hline 14 (J.B.) & $\begin{array}{l}\text { Explicita uma dica importante, que é } \\
\text { perceber o espaço vazio para pegar a } \\
\text { bola (bandeira). }\end{array}$ \\
\hline 15 (J.P.) & $\begin{array}{l}\text { Identifica que jogou pique-bandeira } \\
\text { com espaços menores e menos } \\
\text { jogadores. Explica com detalhes como se } \\
\text { joga. } \\
\text { Cita que jogar em espaço menor e } \\
\text { com menos jogadores possibilitou } \\
\text { jogarem mais. }\end{array}$ \\
\hline $16(\mathrm{~K})$. & Não fez. \\
\hline 17 (L.) & Não fez. \\
\hline 18 (L.) & $\begin{array}{l}\text { Inseriu uma pesquisa sobre a } \\
\text { importância dos jogos infantis. } \\
\text { Utilizou-se do desenho para explicar } \\
\text { como se joga. }\end{array}$ \\
\hline 19 (L.) & Não fez. \\
\hline 20 (M.) & Explica com detalhes como se joga. \\
\hline 21 (N.M.) & $\begin{array}{l}\text { Explica com detalhes como jogou e } \\
\text { expõe todas as regras transformadas. } \\
\text { Expõe: Senti dificuldade de pegar a } \\
\text { bandeira. }\end{array}$ \\
\hline 22 (N.C.) & $\begin{array}{l}\text { Explica como se joga e expõe todas } \\
\text { as regras transformadas, utilizando-se } \\
\text { do desenho. }\end{array}$ \\
\hline $23(\mathrm{~N})$. & Não fez. \\
\hline
\end{tabular}

\section{Aula 14: Diário da aula}

Nessa aula foram solicitados os registros dos alunos referentes à última aula $\mathrm{e}$ entregou-se o registro comentado e acrescentado com bilhetinhos coloridos para os alunos que deixavam de cumprir alguns critérios combinados para fazer o registro. Depois disso formos à quadra. 


\section{Observações:}

As discussões realizadas no final da última aula revelam a dificuldade dos alunos em resolver conflitos entre amigos usando a conversa. Eles solicitam muito a atitude da professora para ajudá-los quando encontram problemas. Isso fez com que eu pensasse sobre o que fazer para melhorar essa situação. Então, resolvi retomar essa discussão na aula e combinar algumas coisas com os alunos.

Os alunos sentados em círculo foram questionados: $O$ que combinamos no último momento da aula passada?

Os alunos responderam: Falamos sobre o que fizemos na aula.

Professora: Na roda de conversa, lembro que vocês começaram a falar dos problemas que tiveram com os amigos. Vocês se recordam disso?Eu quero saber o que foi dito sobre esta atitude de vocês?

6 (G.B.): Não devemos tentar resolver problemas só no final da aula.

11 (I.C.) e 20 (M.): Porque precisamos resolver os problemas na hora que aparecem.

Professora: Qual é a melhor maneira de se resolver problemas?

8 (G.): Através da conversa.

15 (J.P.): Pedindo tempo no jogo para todos ouvirem o problema e tentar ajudar.

Professora: É isso mesmo, na aula de hoje vamos fazer um novo acordo.Se tiver algum problema com o amigo, vocês, ou com relação ao jogo, é necessário conversar para tentar chegar num acordo. Se o problema persistir, aí, sim, vocês devem me procurar para ajudá-los a resolver.

Depois do acordo feito com os alunos, foi proposto o jogo pique-bandeira, mas agora com duas bolas.

A opção de utilizar um jogo que os alunos já conheciam se justifica em focar a observação, exclusivamente, do conteúdo atitudinal, que se refere ao combinado feito com os alunos.

O jogo começou e depois de um tempo a aluna 15 (J.P.) pediu para resolver um problema com o amigo. Eu perguntei a ela: Você já tentou conversar com o seu amigo?

15 (J.P.): Sim, mas não deu certo. (aluna) 
Professora: Então, que tal pedir tempo no grupo e conversar, expondo o problema e pedindo ajuda para resolver?

A aluna fez o que lhe foi sugerido. O grupo conversou e parece que conseguiu entrar num acordo e voltar ao jogo.

É importante lembrar que os alunos foram divididos em quatro equipes e cada duas equipes jogavam numa das quadras disponíveis nessa aula.

Num grupo percebeu-se, após certo tempo de prática, que o aluno 13 (J.) não dava chance a ninguém para tentar buscar a bandeira e fazer o ponto. Os outros componentes da equipe não se manifestavam contra essa atitude de 13 (J.) porque para eles essa situação estava cômoda, ou por medo de ter que se arriscar mais no jogo. Resolvi parar o jogo e discutir com os alunos o que estava acontecendo, e foi pontuada a importância da participação de todos para fazer o ponto no jogo. Proponho aos alunos a criação de uma regra para que a situação exposta pudesse ser mudada.

23 (N.): Se fosse um de cada vez tentar buscar uma das bandeiras.

8 (G.): Mas eu não quero tentar pegar a bandeira.

Professora: Mas você deve tentar para aprender.

Além disso, digo ao aluno: Muitas vezes, não gostamos de fazer aquilo que não sabemos e quando aprendemos passamos a gostar porque acaba se tornando fácil de fazer. Vá, tente, eu sei que você conseguirá, mas precisa tentar.

Os alunos voltaram a jogar e a participação melhorou muito, quase nunca paravam o jogo para discutir problemas, pois respeitavam as regras.

Em outro momento, houve um grupo em que foi possível notar que os alunos aplicavam o combinado para resolver os problemas, mas demoravam muito nas discussões e jogavam pouco por isso. Resolvi não intervir porque queria que os alunos percebessem por si mesmos o problema e se organizassem para resolvê-lo.

Considero que, por ter sido a primeira vez em que eles jogavam com esses combinados, faltava-Ihes tempo para se organizar e lidar com aquela forma de resolver os problemas.

$\mathrm{Na}$ roda de conversa, pergunto aos alunos qual foi o objetivo da aula. 13 (J.): Resolver os problemas sem ficar chamando a professora o tempo todo. A professora pergunta: Quais foram os combinados que fizemos no início da aula para que isso não acontecesse mais? 
6 (G.B.): Tem que tentar resolver sem ajuda da professora.

Professora: Mas o que foi combinado?

10 (I.C.): Parar o jogo e conversar, até três vezes. Se não melhorar podia chamar a professora para ajudar a resolver.

Professora: O que vocês acharam da experiência de agir dessa forma no jogo?

8 (G.): Teve alguns problemas, mas desse jeito conseguimos ter mais calma para resolver sozinhos nossos problemas.

3 (C.): No meu grupo tivemos problemas de desrespeito às regras e, às vezes, a gente esquecia e pedia para a professora resolver. Mas ela pedia para conversarmos e tentarmos resolver, então fazia a roda e conversávamos até achar uma solução. Mas não foi nada fácil. (alunos)

Professora: É importante lembrar que esse nosso combinado não serviu apenas para esta aula; ele deve usado em todas as aulas de Educação Física e em qualquer atividade em que vocês encontrem problemas para serem resolvidos.

Percebi nessa aula que os alunos se esforçaram para resolver os problemas que encontravam, embora demonstrem dificuldades para resolvê-los sem gastar muito tempo. Nota-se que alguns dão muito valor ao cumprimento das regras e outros tentavam burlar as regras o tempo todo.

O interessante é que não houve nenhum caso em que precisei retirar aluno da aula por causa de mau comportamento, desrespeito às regras ou por atrapalhar os outros. Isso mostra que a estratégia de ensinar os alunos a utilizarem a conversa foi eficiente.

\section{Aula 14: Observações da professora sobre os registros dos alunos}

Critérios de avaliação (observar se os alunos citam respostas coerentes com o que foi trabalhado em aula):

1. Explica como se joga?

2. Cita os problemas encontrados e como foram resolvidos ou não?

3. Insere outras formas de linguagem para registrar ou outros materiais para complementar o seu registro? 
TABELA 13 - Aula 14 - Observações da professora

\begin{tabular}{|c|c|}
\hline 1 (A.B.) & $\begin{array}{l}\text { Explica como jogou. } \\
\text { Cita os problemas: Tinha uma menina } \\
\text { que queria pegar a bola, ela passava } \\
\text { por onde não podia. Nós nos } \\
\text { reunimos, conversamos e foi tudo } \\
\text { bem. }\end{array}$ \\
\hline 2 (B.) & Explica como jogou. \\
\hline $3(\mathrm{C})$. & $\begin{array}{l}\text { Explica como jogou. } \\
\text { Cita os problemas: Teve uma menina } \\
\text { que passava da faixa do canto e } \\
\text { falava que não podia ser pega. O meu } \\
\text { grupo falou para a professora. Ela } \\
\text { disse para o grupo se reunir e } \\
\text { conversar com ela. Foi uma bagunça } \\
\text { porque além do problema da menina } \\
\text { tinham outros problemas. }\end{array}$ \\
\hline $4(\mathrm{~F})$. & Explica como jogou. \\
\hline $5(\mathrm{~F})$. & Não fez. \\
\hline 6 (G.B.) & Não fez. \\
\hline 7 (G.R.) & $\begin{array}{l}\text { Explica como jogou. } \\
\text { Inseriu outra forma de linguagem para } \\
\text { registrar, o desenho, e expôs adequa- } \\
\text { damente várias situações do jogo. }\end{array}$ \\
\hline 8 (G.) & $\begin{array}{l}\text { Explica como jogou. } \\
\text { Cita: Essa aula mostrou que seguir } \\
\text { regras é a melhor coisa para o jogo } \\
\text { dar certo e não ter problemas. }\end{array}$ \\
\hline 9 (I.) & $\begin{array}{l}\text { Explica como jogou. } \\
\text { Insere outras formas de linguagem } \\
\text { para registrar (o desenho) e expõe } \\
\text { como se joga. }\end{array}$ \\
\hline
\end{tabular}




\begin{tabular}{|c|c|}
\hline 10 (I.C.) & $\begin{array}{l}\text { Explica como se joga. } \\
\text { Expõe que aprendeu que: Os } \\
\text { problemas devem ser resolvidos na } \\
\text { hora e sem ficar chamando a } \\
\text { professora. } \\
\text { Insere outras formas de linguagem } \\
\text { para registrar (o desenho) e expõe } \\
\text { como se joga. }\end{array}$ \\
\hline 11 (I.C.) & $\begin{array}{l}\text { Explica como jogou. } \\
\text { Inseri outras formas de linguagem } \\
\text { para registrar o desenho, e expõe } \\
\text { como se joga. }\end{array}$ \\
\hline 12 (J.) & $\begin{array}{l}\text { Explica como jogou. } \\
\text { Insere outras formas de linguagem } \\
\text { para registrar (o desenho) e expõe } \\
\text { como se joga. }\end{array}$ \\
\hline $13(\mathrm{~J})$. & $\begin{array}{l}\text { Explica como jogou. } \\
\text { Insere outras formas de linguagem } \\
\text { para registrar (o desenho) e expõe } \\
\text { como se joga. }\end{array}$ \\
\hline 14 (J.B.) & $\begin{array}{l}\text { Explica como jogou. } \\
\text { Insere outras formas de linguagem } \\
\text { para registrar (o desenho), e expõe } \\
\text { como se joga. }\end{array}$ \\
\hline 15 (J.P.) & $\begin{array}{l}\text { Explica como jogou. } \\
\text { Eu queria ficar no ataque e as } \\
\text { pessoas do meu grupo não deixavam. } \\
\text { Só consegui resolver quando } \\
\text { conversei com o grupo e eles me } \\
\text { deram a chance de tentar. } \\
\text { Insere outras formas de linguagem } \\
\text { para registrar (o desenho) e expõe } \\
\text { como se joga. }\end{array}$ \\
\hline
\end{tabular}




\begin{tabular}{|c|c|}
\hline $16(\mathrm{~K})$. & Não fez. \\
\hline 17 (L.) & Não fez. \\
\hline 18 (L.) & $\begin{array}{l}\text { Inseriu uma pesquisa que tratava } \\
\text { sobre o direito e a importância de } \\
\text { jogar, e também a necessidade de } \\
\text { tomar iniciativa e se arriscar mais nos } \\
\text { jogos. A aluna também investigou } \\
\text { outros jogos da cultura infantil e } \\
\text { marcou no texto tudo o que } \\
\text { considerou que tinha relação com o } \\
\text { que foi ensinado na aula de Educação } \\
\text { Física. }\end{array}$ \\
\hline 19 (L.) & $\begin{array}{l}\text { Explica como jogou por meio do } \\
\text { desenho. }\end{array}$ \\
\hline 20 (M.) & Não fez. \\
\hline 21 (N.M.) & Não fez. \\
\hline 22 (N.C.) & Explica como jogou. \\
\hline $23(\mathrm{~N})$. & Explica o jogo. \\
\hline
\end{tabular}

\section{Aula 15: Diário da aula}

Nesta aula alguns alunos foram solicitados a realizar a reunião individual com a professora. O critério de escolha dos alunos era aqueles que atribuíram nota, na auto-avaliação, muito superior ao que demonstraram nas aulas. (alunos) Optou-se propor aula livre e não foi cobrado registro nessa aula.

Os alunos eram chamados um a um para tomarem contato com as minhas anotações sobre seu desempenho nas aulas e o que revelavam os seus registros diários. Os argumentos revelando que a nota que se haviam atribuído na auto-avaliação não estava coerente com o que apresentaram nas aulas no decorrer do período avaliado eram pautados nesses dados.

Depois dessa análise, pedia-se para o aluno pensar e dizer que nota ele realmente merecia.

Foi interessante observar que, com todos os alunos solicitados para reunião individual, houve a conscientização de que sua nota precisava ser mudada, e 
eles sugeriram, muitas vezes, uma nota abaixo do que eu considerava que mereciam. Com os alunos que demonstravam esse tipo de atitude eu fazia algumas intervenções que justificavam uma nota mais coerente.

A reunião individual durava poucos minutos e eu atuava como escriba para ganhar tempo. Além de atribuir uma nova nota, também era organizada uma lista com a colaboração do aluno sobre o que precisava melhorar, quais eram suas metas dali para frente. Desse modo, era firmado um acordo, que era registrado, o qual simbolicamente se tornou algo significativo para os alunos.

\section{Aula 16: Diário da aula}

Percebi que nos registros que os alunos esquecem de fazer e acabam entregando atrasado poucos são os critérios contemplados.

Pergunto-me o que preciso fazer para melhorar essa situação.

Resolvi retomar a discussão com os alunos: Por que é importante registrar?

Três pontos foram levantados pelos próprios alunos:

1) para saber e lembrar o que aprendeu ou não;

2) para melhorar aquilo em que sentiu dificuldade;

3) para ajudar a professora a avaliar o que deu certo ou errado na aula.

\section{Aula 17: Diário da aula}

$\mathrm{Na}$ sala de leitura, com os alunos sentados bem à vontade, os registros foram entregues com comentários e com os bilhetinhos da professora para os alunos melhorarem alguns pontos que havíamos combinado e não estavam contemplados nos registros. (alunos)

Foram retomados os critérios de avaliação do registro, mostrando o exemplo exposto na sala de aula.

Foram entregues os portfólios dos alunos e foi explicada a ordem do mesmo, com todas as matrizes: carta de apresentação do portfólio; explicações sobre o projeto; meus registros diários e o que mais aprendi e o que senti dificuldade; por que escolhi este registro para representar o que mais aprendi; por que escolhi este registro para representar o que senti dificuldade. Ainda foi dito aos alunos que não haviam feito reunião individual com a professora na última aula que nessa aula eles seriam solicitados e deveriam ler as anotações da professora sobre o que precisam melhorar. 
Foi retomado com todos os alunos o que precisava melhorar de forma coletiva e os jogos que já haviam sido transformados.

Também foi lembrado que os jogos de correr já tinham sido feitos, assim como a necessidade, levantada pelos alunos, de aprender a correr melhor em jogos de perseguição.

Ao focar os pontos que ainda precisavam melhorar, a habilidade de saltar foi enfatizada na proposta dessa aula. A atividade era transformar os jogos de saltar já realizados para contemplar os objetivos que precisavam alcançar com essa habilidade motora.

Os alunos foram divididos em três grupos. Alguns criaram novos jogos ou só transformaram as regras dos jogos de saltar que haviam executado em outras aulas. (alunos)

Percebeu-se que discutiam e construíam novas regras e jogos respeitando e ouvindo as idéias dos colegas. Eles se mostravam bastante motivados com a tarefa.

A professora auxiliava os grupos, circulando entre os mesmos e fazendo intervenções que ajudavam os alunos a sistematizarem suas idéias e definirem como ficaria o jogo. (alunos)

\section{Observação:}

Considero que a experiência de trabalho em grupo foi bem-sucedida, deu autonomia para os alunos criarem o que iriam aprender nas próximas aulas. Essa iniciativa auxiliou os alunos a atuarem como agentes criadores de novas formas de fazer o que sabiam: jogar.

\section{Aula 17: Observações da professora sobre os registros dos alunos}

Critérios de avaliação (observar se os alunos citam respostas coerentes com o que foi trabalhado em aula):

1. Identificação da proposta da aula.

2. Problemas que ocorreram durante a proposta. Como resolveu.

TABELA 14 - Aula 17 - Observações da professora

\begin{tabular}{|l|l}
\hline 1 (A.B.) & Faltou. \\
\hline
\end{tabular}




\begin{tabular}{|c|c|}
\hline 2 (B.) & Não fez. \\
\hline $3(\mathrm{C})$. & $\begin{array}{l}\text { Escreve o que aconteceu na aula. } \\
\text { Expõe o problema ocorrido: Uma } \\
\text { colega disse que minha letra era feia } \\
\text { para fazer o registro do grupo. }\end{array}$ \\
\hline $4(\mathrm{~F})$. & $\begin{array}{l}\text { Escreve o que aconteceu na aula: } \\
\text { trabalho em grupo e criação dos jogos } \\
\text { de saltar. }\end{array}$ \\
\hline $5(\mathrm{~F})$. & $\begin{array}{l}\text { Apenas descreve o que aconteceu na } \\
\text { aula. }\end{array}$ \\
\hline 6 (G.B.) & Não fez. \\
\hline 7 (G.R.) & Escreve o que aconteceu na aula. \\
\hline 8 (G.) & Não fez. \\
\hline 9 (I.) & Escreve o que aconteceu na aula. \\
\hline 10 (I.C.) & Escreve o que aconteceu na aula. \\
\hline 11 (I.C.) & $\begin{array}{l}\text { Escreve o que aconteceu na aula. } \\
\text { Problema: Não deu tempo de escrever } \\
\text { tudo que o grupo falava. }\end{array}$ \\
\hline $12(\mathrm{~J})$. & Não fez. \\
\hline $13(\mathrm{~J})$. & Escreve o que aconteceu na aula. \\
\hline 14 (J.B.) & Escreve o que aconteceu na aula. \\
\hline 15 (J.P.) & Escreve o que aconteceu na aula. \\
\hline $16(\mathrm{~K})$. & Não fez. \\
\hline 17 (L.) & Não fez. \\
\hline 18 (L.) & $\begin{array}{l}\text { Escreve o que aconteceu na aula. } \\
\text { Trouxe uma pesquisa sobre o que são } \\
\text { regras. Disse que sentiu necessidade } \\
\text { de saber mais sobre isso quando } \\
\text { transformava os jogos com os } \\
\text { amigos. }\end{array}$ \\
\hline 19 (L.) & $\begin{array}{l}\text { Escreve o que aconteceu na aula. } \\
\text { Cita que o problema ocorrido em seu } \\
\text { grupo foi que um colega não prestava }\end{array}$ \\
\hline
\end{tabular}




\begin{tabular}{|l|l|}
\hline 20 (M.) & $\begin{array}{l}\text { atenção no que as pessoas falavam e } \\
\text { ficava brincando o tempo todo. }\end{array}$ \\
\hline 21 (N.M.) & Escreve o que aconteceu na aula. \\
\hline 22 (N.C.) & $\begin{array}{l}\text { Escreve o que aconteceu na aula. } \\
\text { Cita que o problema ocorrido em seu } \\
\text { grupo foi quando organizaram as } \\
\text { idéias para escrever como ficaria o } \\
\text { jogo. }\end{array}$ \\
\hline 23 (N.) & Escreve o que aconteceu na aula. \\
\hline & Escreve o que aconteceu na aula. \\
\hline
\end{tabular}

\section{Aula 18: Diário da aula}

Em sala de aula, solicitei os registros que os alunos haviam feito da aula do dia $4 / 5 / 2007$. Alguns alunos entregaram registros de outras aulas, contemplando 0 que os bilhetinhos feitos pela professora indicavam que precisavam melhorar. Após essa etapa, perguntei aos alunos o que acharam dos resultados apresentados nessa primeira parte do projeto em seus portfólios. Eu queria saber se haviam lido em casa, e muitos responderam que gostaram dos resultados. Porém, a aluna 22 (N.C.) surpreendeu com a sua resposta: Eu achei que ele [o portfólio] mostrou uma avaliação mais justa.

Combinamos qual equipe iria apresentar o seu jogo na aula. $O$ jogo foi uma variação e junção dos jogos aumenta-aumenta e pula-mula. Entreguei ao grupo o registro da transformação desses jogos, feito na última aula, e fomos para a quadra.

$\mathrm{Na}$ quadra, os alunos foram para o círculo central e retomamos os objetivos que precisavam ser atingidos.

Solicitei que os alunos do primeiro grupo ensinassem o jogo que haviam transformado e todos os outros alunos a sua volta ficaram prestando muita atenção para entender como iriam jogar.

Após a explicação e demonstração de como se joga, alertei os alunos quanto às maneiras como poderiam se prevenir para não se machucarem, uma vez que os bastões que ficavam entre as selas poderiam ser pisados por algum aluno e esse escorregaria. Combinamos que a distância entre as selas e os 
bastões deveria ser aquela que fosse realmente possível ultrapassar com o salto. (aluno)

Em seguida, solicitei aos alunos que trabalhassem em duplas ou trios para a prática do jogo. Esse momento foi bastante interessante, pois todos os alunos buscaram seu espaço, montaram o jogo, uns ajudando os outros, e depois se organizaram e começaram a jogar sem nenhuma intervenção da professora.

O jogo transformado pelo grupo 1, trazia dois desafios: saltar o amigo que estava entre dois bastões postos no chão e saltar em distância mais dois bastões. O mais interessante era que cada um na sua vez podia regular a altura da sela e, também a distância entre os bastões para a execução do salto em altura. Isso auxiliava os alunos a perceberem suas possibilidades e seus limites, gerando autodesafio.

Foi possível perceber que o movimento de saltar com as pernas afastadas no pula-sela estava melhor do que quando os alunos executaram da primeira vez. Eles corriam com mais velocidade, tinham mais impulsão e as pernas permaneciam mais estendidas. Ao mesmo tempo, percebia-se que os alunos executavam os movimentos com mais confiança. (alunos)

Disse aos alunos: Quero aproveitar para dizer que fiquei observando vocês praticarem este jogo e percebi que algumas pessoas precisam desafiar-se mais quando saltar no pula-sela.

6 (G.B.): Professora, na verdade eu vi na figura do jornal que a senhora trouxe que o jogo de pular sela é assim. O aluno demonstra a sela alta com as mãos nos joelhos.

Discutimos que a sela não deve ser baixa demais. Foi sugerido que quem quisesse se desafiar um pouco mais deveria pedir ao amigo para subir a altura da sela e saltá-la como foi exposto. Ainda ressaltei que sabia que muitos poderiam tentar, pois iriam conseguir. (aluno)

Os alunos voltam ao jogo.

Fiquei circulando e dando sugestões sobre o espaço em que estavam fazendo o jogo, pois alguns se atrapalhavam, pegando muito espaço para correr. Outros alunos perguntavam se estava certo ou errado, pediam para eu ficar vendo e solicitavam uma opinião. (alunos) 
Pedi para os alunos pararem o jogo e propus que podiam criar novas formas de saltar e que a partir daquele momento não precisavam executar o jogo só com os saltos indicados pelo grupo que propôs o jogo nessa aula.

Alguns alunos continuaram executando o salto afastado. Para esses alunos ele ainda era um desafio, porém o fato de diversificar a maneira de saltar, para alguns que sentiam. dificuldades com o salto afastado, foi uma oportunidade de experimentar outras formas de saltar. (alunos)

Observei que a inserção dessa proposta abriu possibilidades de atingir o objetivo da aula (saltar melhor, participar e prestar mais atenção nas discussões), utilizando outras formas de saltar.

Continuei circulando na quadra e solicitando aos alunos que esforçassem e se desafiassem mais. Inseri, então, outra regra: não poderiam repetir a mesma forma de saltar mais de três vezes. Portanto, era preciso pensar em possibilidades motoras que pudessem diversificar seus saltos.

Com essa intervenção, percebi que a vivência do saltar ficou mais rica e aumentou ainda mais a motivação dos alunos na aula.

$\mathrm{Na}$ roda de conversa, eu os lembrei de qual seria o grupo que na próxima aula iria apresentar o jogo transformado.

Perguntei aos alunos: Cumprimos com os objetivos de saltar melhor, participar e prestar mais atenção nas discussões da aula?

22 (N.C.): Sim, porque nos saltos precisávamos tentar pegar impulso.

8 (G.): Ah, também precisávamos correr rápido e dar o impulso na hora certa.

Pergunto: Qual era a hora certa de dar o impulso?

8 (G.): Quando chegava próximo dos bastões e tinha que ultrapassar a sela.

10 (I.C.): Precisávamos prestar atenção na distância entre os bastões e não pisar neles e acabar escorregando.

4 (F.): Ver a medida dos bastões, a distância e altura que tínhamos que saltar.

19 (L.): A gente também precisava se desafiar um pouco a cada vez que chegava a sua vez.

Falo aos alunos: Tudo o que vocês disseram ajudou a cumprir com o objetivo da nossa aula: correr para pegar mais impulso, prestar atenção na distância e altura que precisavam saltar e superar desafios cada vez maiores.

10 (I.C.): Professora, eu também quero lembrar que outra coisa importante nessa aula foi mudar o jeito de pular, a gente aprende a criar outras formas. 
Falo aos alunos: É verdade, mudar as maneira de saltar ajuda a conhecer outros jeitos de impulsionar-se e aterrissar após a fase aérea do salto.

Professora: Para finalizar a aula, quero dizer a vocês que na aula de hoje gostei da participação, o empenho para melhorar e o fato de vocês conseguirem resolver os problemas sozinhos com os seus colegas. Isso mostra quanto melhoraram em comparação com outras aulas em que não conseguiam fazer isso. Também quero apresentar, rapidamente, uma informação trazida pela 18 (L.) em seu registro.

Foi exposto aos alunos o artigo trazido pela aluna 18 (L.), que tratava do direito das crianças de jogarem, que deve ser respeitado pelos adultos. A pesquisa também expunha que as crianças aprendem por meio de jogos.

Perguntei aos alunos: Será que o que o autor defende nesta pesquisa, com relação à possibilidade de aprender por meio de jogos, está acontecendo em nossas aulas?

A maioria dos alunos se manifesta dizendo que sim; alguns alunos complementam: Principalmente sobre como cooperar e respeitar os amigos.

\section{Aula 18: Observações da professora sobre os registros dos alunos}

Critérios de avaliação (observar se os alunos citam respostas coerentes com o que foi trabalhado em aula):

1. Como se joga o jogo proposto?

2. Quais as dificuldades encontradas? Conhece alguma dica para melhorar?

3. Houve algum tipo de problema? Como resolveu?

TABELA 15 - Aula 18 - Observações da professora

\begin{tabular}{|l|l|}
\hline 1 (A.B.) & Não fez. \\
\hline 2 (B.) & $\begin{array}{l}\text { Explica como realizou o jogo } \\
\text { proposto, utilizando-se da escrita. }\end{array}$ \\
\hline 3 (C.) & $\begin{array}{l}\text { Explica como realizou o jogo } \\
\text { proposto, utilizando-se da escrita. } \\
\text { Expõe: } A \text { minha dupla não abaixava } \\
\text { para eu fazer bem o salto na sela. Ás } \\
\text { vezes, ela saltava apoiando as mãos }\end{array}$ \\
\hline
\end{tabular}




\begin{tabular}{|c|c|}
\hline & $\begin{array}{l}\text { colocando muita força nas minhas } \\
\text { costas. }\end{array}$ \\
\hline $4(F)$. & $\begin{array}{l}\text { Explica como jogou, utilizando-se da } \\
\text { escrita. } \\
\text { As dificuldades encontradas foram: } \\
\text { saltar a sela numa altura maior. } \\
\text { Expõe que aprendeu uma dica para } \\
\text { melhorar o saltar: Pegar mais impulso } \\
\text { com a corrida e prestar atenção na } \\
\text { altura e na distância que preciso } \\
\text { saltar. }\end{array}$ \\
\hline $5(\mathrm{~F})$. & $\begin{array}{l}\text { Escreve e desenha como jogou. O } \\
\text { que é interessante em seu desenho } \\
\text { são as divisões de espaço e a prática } \\
\text { do jogo realizado em duplas. } \\
\text { Expõe: Às vezes, quando eu saltava } \\
\text { pisava nos bastões e escorregava. Eu } \\
\text { resolvi este problema, só quando } \\
\text { diminuí a distância entre os bastões } \\
\text { quando ia saltar }\end{array}$ \\
\hline 6 (G.B.) & Não fez. \\
\hline 7 (G.R.) & $\begin{array}{l}\text { Explica como realizar o jogo proposto, } \\
\text { utilizando-se da escrita. } \\
\text { Diz que teve dificuldade no pula-sela } \\
\text { por causa dos bastões que havia } \\
\text { entre a sela. Expõe: Melhorei nesta } \\
\text { parte do jogo quando pude saltar de } \\
\text { outras maneiras. }\end{array}$ \\
\hline 8 (G.) & $\begin{array}{l}\text { Explica como se joga, por meio do } \\
\text { desenho, de maneira muito clara. } \\
\text { Diz que enfrentou problemas com o } \\
\text { seu parceiro: Ele me machucou } \\
\text { apoiando a mão muito forte nas }\end{array}$ \\
\hline
\end{tabular}




\begin{tabular}{|c|c|}
\hline & minhas costas. \\
\hline 9 (I.) & $\begin{array}{l}\text { Explica como se joga, por meio do } \\
\text { desenho. } \\
\text { Um problema foi: A minha amiga } \\
\text { deixava a altura da sela muito baixa. } \\
\text { A solução foi mostrar qual era a altura } \\
\text { melhor para mim toda vez que ia } \\
\text { saltar. Outra dificuldade: Fazer o salto } \\
\text { afastado na sela. Melhorou quando a } \\
\text { professora deixou a gente criar outras } \\
\text { formas de saltar. }\end{array}$ \\
\hline 10 (I.C.) & $\begin{array}{l}\text { Explica como se joga, por meio do } \\
\text { desenho, de maneira muito clara. } \\
\text { Escreve que gostou do momento da } \\
\text { aula em que a professora disse para } \\
\text { criar novas formas de saltar. }\end{array}$ \\
\hline 11 (I.C.) & $\begin{array}{l}\text { Explica como se joga, por meio de } \\
\text { história em quadrinhos. } \\
\text { Expõe a dica: pegar distância para } \\
\text { correr e saltar com mais impulso. } \\
\text { Escreve que gostou do momento da } \\
\text { aula em que a professora disse para } \\
\text { criar novas formas de saltar. Ela } \\
\text { desenha as formas que criou e } \\
\text { vivenciou e aponta a forma de saltar } \\
\text { que mais gostou de executar. }\end{array}$ \\
\hline 12 (J.) & $\begin{array}{l}\text { Explica como se joga, por meio do } \\
\text { desenho, de maneira muito clara. } \\
\text { Expõe a dica: A gente precisa correr } \\
\text { para pegar impulso, jogar o corpo } \\
\text { para frente e apoiar as mãos nas } \\
\text { costas do amigo quando fazia o salto } \\
\text { sob a sela. }\end{array}$ \\
\hline
\end{tabular}




\begin{tabular}{|c|c|}
\hline & $\begin{array}{l}\text { Obs.: Ele cumpriu com a maioria dos } \\
\text { critérios propostos. Isso surpreendeu; } \\
\text { este é um aluno que faz poucos } \\
\text { registros. }\end{array}$ \\
\hline 13 (J.) & $\begin{array}{l}\text { Explica como realizar o jogo proposto, } \\
\text { utilizando-se da escrita. }\end{array}$ \\
\hline 14 (J.B.) & $\begin{array}{l}\text { Explica como realizar o jogo proposto, } \\
\text { utilizando-se da escrita e do desenho. } \\
\text { Expõe que as dicas mais importantes } \\
\text { que aprendeu no jogo foi: Dar impulso } \\
\text { para saltar melhor; escolher a altura } \\
\text { da sela que quer saltar; tomar } \\
\text { distância, correr bem rápido e saltar. } \\
\text { Ainda diz que eles criaram uma nova } \\
\text { regra para o jogo: quem pisasse nos } \\
\text { bastões após saltar virava sela. }\end{array}$ \\
\hline 15 (J.P.) & Não fez. \\
\hline $16(\mathrm{~K})$. & $\begin{array}{l}\text { Explica como realizar o jogo proposto, } \\
\text { utilizando-se da escrita. } \\
\text { O aluno explicita que o que mais } \\
\text { gostou nessa aula foi quando pôde } \\
\text { criar novas formas de saltar. Expõe } \\
\text { que a maneira que mais gostou foi } \\
\text { quando saltou virando estrela e ainda } \\
\text { ressalta que foi importante se } \\
\text { concentrar para executar esse salto. }\end{array}$ \\
\hline 17 (L.) & $\begin{array}{l}\text { Explica como realizar o jogo proposto, } \\
\text { utilizando-se da escrita e do desenho. } \\
\text { Expõe ter ficado satisfeita com os } \\
\text { amigos, que disseram ter gostado do } \\
\text { jogo que o seu grupo criou. }\end{array}$ \\
\hline 18 (L.) & $\begin{array}{l}\text { Explica como realizar o jogo proposto, } \\
\text { utilizando-se da escrita e do desenho. }\end{array}$ \\
\hline
\end{tabular}




\begin{tabular}{|l|l|}
\hline 19 (L.) & $\begin{array}{l}\text { Diz que criaram uma nova regra para } \\
\text { o jogo: quem pisasse nos bastões } \\
\text { após saltar virava sela. }\end{array}$ \\
\hline 20 (M.) & $\begin{array}{l}\text { Explica como realizar o jogo proposto, } \\
\text { utilizando-se do desenho. } \\
\text { Diz que o mais gostou foi jogar os } \\
\text { dois jogos, aumenta-aumenta e pula- } \\
\text { mula, misturados. }\end{array}$ \\
\hline 21 (N.M.) & $\begin{array}{l}\text { Explica como realizar o jogo proposto, } \\
\text { utilizando-se do desenho. } \\
\text { Fez um ótimo registro: a explicação } \\
\text { está fácil de entender e muito bem- } \\
\text { feita. } \\
\text { Explica como realizar o jogo proposto, } \\
\text { utilizando-se da escrita. } \\
\text { Diz que sentiu dificuldades para fazer } \\
\text { o salto afastado. } \\
\text { Expõe: Não conseguia saltar os } \\
\text { bastões que ficavam no chão. } \\
\text { Explica como realizar o jogo proposto, } \\
\text { utilizando-se da escrita e do desenho. } \\
\text { Expõe o que aprendeu: Correr para } \\
\text { dar impulso e saltar melhor; tentar se } \\
\text { superar aumentando cada vez mais } \\
\text { alto para saltar; tem várias formas de } \\
\text { saltar. }\end{array}$ \\
\hline $\begin{array}{l}\text { Explica como realizar o jogo proposto, } \\
\text { utilizando-se da escrita e do desenho. } \\
\text { Diz que criaram uma nova regra para } \\
\text { o jogo: quem pisasse nos bastões } \\
\text { após saltar virava sela. }\end{array}$ \\
\hline (N.)
\end{tabular}


Foi possível perceber que os alunos gostaram muito dessa aula. Os desenhos representam muito bem o jogo. Considero que a prática dessa aula foi bastante significativa; isso se comprova com a riqueza dos detalhes expostos pelos alunos.

O grupo que criou o jogo demonstrou que todos estavam bem unidos e sabiam do que se tratava, principalmente quando tiveram que ensinar a turma a jogar. Percebe-se em alguns registros que o aluno aguarda os meus comentários para ver o que achei da sua produção.

\section{Aula 19: Diário da aula}

A aula foi iniciada na sala de aula, com a entrega dos registros da última aula e entrega dos registros que estavam comigo para observar e inserir comentário.

Disse aos alunos qual era a equipe que iria apresentar e ensinar o seu jogo nessa aula. Depois disso, fomos para quadra. Dei a folha a eles e solicitei que os integrantes do grupo 2 apresentassem e ensinasse aos outros alunos o jogo que haviam transformado.

Eles disseram que haviam esquecido o que tinham feito; resolvi ler junto com o grupo o que haviam registrado. O que haviam registrado era a transformação das regras do jogo quebra-canela, mas as regas estavam difíceis de entender.

Foi solicitado que demonstrassem na prática o que haviam pensado, e eles colocaram dois alunos batendo corda e outro que corrida e entrava com a corda em movimento, saltava uma vez e saía.

Fiquei observando o que estavam apresentando e interrompi a execução, perguntando-Ihes: Como jogaram quebra-canela pela primeira vez?

Os alunos responderam, um ajudando o outro, apontaram a necessidade de formar uma fila e saltar por cima do bastão que duas pessoas seguravam.

Pergunto: Vocês saltavam sempre na mesma altura?

Os alunos responderam que não; podia aumentar ou não a altura, a decisão dependia da pessoa que ira saltar o bastão.

Questiono: O jogo que vocês escolheram para transformar (o quebra-canela), que exige o salto em altura, dá para ser comparado com o tipo de jogo que vocês estão apresentando, isto é, ele trabalha o salto em altura?

O grupo de alunos fica um tempo pensativo. 
Eu dei um tempo para eles pensarem e tentarem responder, mas como nenhuma resposta foi dada eu resolvi explicar aos alunos que, quando pulamos corda, não há como dosar a altura dos saltos, como exige o jogo quebracanela, pois ao pular corda saltitamos sempre no mesmo ritmo e da mesma forma. Sendo assim, se o objetivo dessa aula era melhorar o salto em distância e altura e a proposta do grupo 2 era transformar o jogo quebra-canela, como podemos fazer isso usando as cordas?

Os alunos sugeriram deixar a primeira parte do jogo de exercício, como haviam pensado, com a corda presa na grade num dos lados para ser batida por uma pessoa. Um segundo desafio foi feito com as duas cordas elásticas: elas foram amarradas em duas extremidades para a realização do salto em altura. (alunos)

Desse modo, foi montado um novo jogo. Aproveitaram a primeira idéia e acrescentaram outras. Ajudei a organizar o grupo e combinamos como seria a explicação para o jogo.

Toda essa discussão para a reconstrução do jogo demorou um pouco, mas valeu a pena, pois foi possível ajudar os alunos a reorganizarem suas idéias de forma coletiva. Eu dei uma pequena introdução para que o grupo 2 explicasse o jogo. Disse aos alunos que o jogo quebra-canela trabalhava o salto em altura e como pular corda não possibilita trabalhar essa habilidade, que era o objetivo da aula (melhorar o salto em altura), ele foi mudado para que pudessem cumprir o que se pretendia alcançar.

Então o grupo 2 ensinou aos outros alunos como ficou o jogo. Foi interessante notar que os alunos explicavam o jogo ajudando uns aos outros.

Os alunos expuseram que duas filas ficariam atrás da primeira corda, que ficaria batendo. Dois por vez deveriam ultrapassar a corda em movimento, sem deixá-la tocar no corpo. Depois disso, deveriam saltar o primeiro desafio, aproveitando a velocidade da corrida em que haviam passado pela corda em movimento, e saltar a primeira corda suspensa que estava com um lado mais alto que o outro. Lembraram que era necessário escolher de que lado iriam saltar. Depois se repetia o mesmo com a segunda corda e deveriam voltar saltando tudo de novo. Mas, nesse momento, a corda que antes era batida virava uma cobrinha suspensa que também deveria ser saltada e a professora que controlaria a altura. 
Um fato ocorrido com a aluna 11 (I.C.) foi que nas primeiras tentativas caiu ao tropeçar numa das cordas, e parou de jogar.

O jogo foi parado e os alunos se aproximaram de mim. Disse a eles que não é porque ocorreu um problema que devemos desistir tão fácil dos nossos desafios, pois é errando que se aprende. Ressaltei a importância da prática para sermos bons em determinadas habilidades motoras. (aluno)

19 (L.): Professora, eu queria dizer uma coisa: eu acho que o importante é fazer e não desistir porque uma hora a gente consegue.

Falo aos alunos: É verdade, quando temos dificuldades com alguma habilidade motora é só com a prática e o entendimento das dicas importantes para a execução da mesma que conseguimos realizá-la com sucesso. Mas, para que isso ocorra, é preciso entender que não é na primeira vez que se tenta realizar uma habilidade mais complexa inserida num jogo que iremos fazê-la da melhor maneira possível, pois demora a aprender algo novo. Então, vamos estabelecer alguns combinados importantes dessa nossa conversa.

Os alunos começam a dar sua opinião e, ao mesmo, tempo a professora atua como escriba, registrando as sugestões e ajudando-os a organizarem as idéias. Os combinados ficaram da seguinte maneira:

1) É errando que se aprende;

2) Tentar executar várias vezes o que não consegue;

3) Nunca desistir;

4) Observar qual é o seu limite e saltar onde é melhor para você;

5) $\mathrm{Na}$ corda batida ou mesmo na cobrinha a professora irá ajudar os alunos que sentem dificuldade;

Depois disso, os alunos voltaram ao jogo e a 11 (I.C.) me procurou e disse que iria tentar mais um pouco.

Observei que o aluno 7 (G.R.) fez todas as etapas do jogo dentro das suas capacidades. Ele estava concentrado e tentava se superar a cada tentativa na habilidade de saltar em altura.

Todo o resto da turma participou com bastante entusiasmo; os alunos procuraram saltar de acordo com as suas capacidades, escolhendo para si a altura mais adequada da corda suspensa.

Observei que a proposta de jogo do segundo grupo deixava os alunos parados tempo demais e em fila, o que acarretava vários problemas: 
1) eles se desconcentravam por causa das conversas paralelas e brincadeiras na fila;

2) a competição entre os dois que saíam lado a lado era inevitável, causava entre os alunos das filas comparações;

3) ficavam contando como ponto o aluno que conseguiu chegar primeiro de cada fila, e com isso perdia-se a qualidade dos movimentos por causa da velocidade de execução.

No final da aula, na roda de conversa, a aluna 10 (I.C.) fala: Como fica o nome deste jogo?

Pergunto: Alguém tem alguma idéia de nome para o jogo praticado hoje?

1 (A.B.): Jogo do salta, salta.

Pergunto: Todos concordam?

Os alunos respondem que sim.

Depois disso, comentei algumas informações da pesquisa que a aluna 19 (L.) inseriu em registro que tratava de sobre curiosidades acerca da corrida de velocidade. Pontuei as informações novas e as que só confirmavam o que já tinha sido abordado na aula. Depois, pontuei a importância de fazer pesquisas e inseri-las nos registros, pois elas aumentam e melhoram o conhecimento sobre o que os alunos aprendem em aula.

O jogo proposto pelo grupo 2 tinha um formato pouco utilizado nas aulas de Educação Física, que corresponde ao tipo de jogo nomeado estafeta. Por esse motivo, algumas atitudes (aguardar em fila, esperar a sua vez, respeitar os colegas que executavam o jogo, sem atrapalhar a sua concentração) apresentaram-se difíceis de serem cumpridos pelos alunos.

Interpreto o medo manifestado pela aluna 11 (I.C.) como conseqüência da falta de vivência desse formato de proposta e também do fato de estar se expondo de uma maneira que não estava acostumada a fazer no grupo.

A exposição da pesquisa da aluna 19 (L.) no final da aula lembrou aos alunos o valor da ação de buscar novos conhecimentos e as informações apresentadas despertaram o interesse dos alunos.

O que o grupo 2 construiu nessa aula tinha característica de estafeta porque havia a divisão do grupo em duas equipes que competiam entre si, precisavam respeitar as regras preestabelecidas de permanecer em fila e esperar a sua vez para completar o percurso com distintas tarefas motoras. Encontra-se em 
FREIRE (1989) que esse formato de prática pode ser considerado jogo porque possui regras e a existência de ganhadores e perdedores. Pautado em Piaget, o autor lembra que os jogos podem ser classificados em três modalidades:

- jogos de exercício;

- jogos simbólicos;

- jogos de regras.

Nessa perspectiva, a proposta do grupo 2 pode ser classificada como jogo de exercício, porque os alunos precisavam cumprir tarefas fixas que enfocavam a prática da habilidade de saltar executada várias vezes e o respeito a algumas regras, já citadas anteriormente.

Com relação à competição que ocorria entre os alunos que participaram da proposta, considero o que FREIRE (1989) afirma quanto à não-apropriação da negação da competição nas aulas de Educação Física escolar. Segundo o autor, ao analisar todos os fatores culturais presentes na sociedade, a competição sempre existiu, portanto já faz parte de nosso contexto cultural, não devendo ser desconsiderada. Ele sugere que haja uma mudança na estruturação das aulas de Educação Física escolar que aprecie o vencido assim como o vencedor, para que o educando possa perceber-se como parte fundamental para a realização de uma prática corporal em que não há vencedor se não houver o vencido.

\section{Aula 19: Observações da professora sobre os registros dos alunos}

Critérios de avaliação (Observar se os alunos citam respostas coerentes com o que foi trabalhado em aula):

1. Como se joga o jogo proposto?

2. Quais as dificuldades encontradas? Conhece alguma dica para melhorar?

3. Houve algum tipo de problema? Como resolveu?

TABELA 16 - Aula 19 - Observações da professora

\begin{tabular}{|l|l|}
\hline 1 (A.B.) & Explica como jogou, utilizando-se da \\
& escrita. \\
& Expõe que sentiu dificuldades após \\
& pisar na corda e acabou caindo. \\
\hline
\end{tabular}




\begin{tabular}{|c|c|}
\hline & $\begin{array}{l}\text { Resolveu seu problema de medo de } \\
\text { cair tentando novamente e não } \\
\text { desistindo de fazer. }\end{array}$ \\
\hline 2 (B.) & $\begin{array}{l}\text { Explica como jogou, utilizando-se da } \\
\text { escrita. } \\
\text { Expõe a dica: quando saltar deve } \\
\text { jogar o corpo para cima o máximo } \\
\text { que puder. }\end{array}$ \\
\hline 3 (C.) & $\begin{array}{l}\text { Explica como jogou, utilizando-se da } \\
\text { escrita. }\end{array}$ \\
\hline $4(\mathrm{~F})$. & $\begin{array}{l}\text { Explica como jogou, utilizando-se da } \\
\text { escrita. } \\
\text { Expõe onde sentiu dificuldades: } \\
\text { Quando tentava saltar as partes em } \\
\text { que a corda estava mais alta. } \\
\text { Explicita que a dica para saltar é } \\
\text { pegar cada vez mais impulso. } \\
\text { Expõe o problema: Meu grupo não } \\
\text { lembrava de nada que haviam feito, } \\
\text { com a ajuda da professora, } \\
\text { montamos um novo jogo. }\end{array}$ \\
\hline $5(\mathrm{~F})$. & $\begin{array}{l}\text { Explica como jogou, utilizando-se da } \\
\text { escrita. } \\
\text { Expõe que nessa aula as dicas eram: } \\
\text { Escolher a melhor altura que } \\
\text { conseguia saltar; não importar se o } \\
\text { amigo ia mais rápido que o outro o } \\
\text { importante era conseguir saltar o } \\
\text { melhor que podia. }\end{array}$ \\
\hline 6 (G.B.) & Não fez. \\
\hline 7 (G.R.) & $\begin{array}{l}\text { Explica como jogou, utilizando-se da } \\
\text { escrita. }\end{array}$ \\
\hline 8 (G.) & Explica como jogou, utilizando-se do \\
\hline
\end{tabular}




\begin{tabular}{|c|c|}
\hline & desenho. \\
\hline 9 (I.) & $\begin{array}{l}\text { Expõe o problema dessa aula: as } \\
\text { pessoas que desistiam nas primeiras } \\
\text { tentativas. } \\
\text { Diz a solução: Entender que é } \\
\text { preciso perder o medo e não desistir. }\end{array}$ \\
\hline 10 (I.C.) & $\begin{array}{l}\text { Expõe que um problema foi o } \\
\text { momento em que uma menina } \\
\text { enroscou o pé na corda e não queria } \\
\text { mais participar. Diz que isso foi } \\
\text { resolvido por meio da conversa entre } \\
\text { a professora e o grupo: Concluímos } \\
\text { que se não tentarmos jamais } \\
\text { conseguiremos superar novos } \\
\text { desafios. }\end{array}$ \\
\hline 11 (I.C.) & $\begin{array}{l}\text { Explica como jogou, utilizando-se da } \\
\text { escrita. } \\
\text { Expõe o problema: Eu não tinha } \\
\text { velocidade. }\end{array}$ \\
\hline $12(\mathrm{~J})$. & $\begin{array}{l}\text { Explica como jogou, utilizando-se da } \\
\text { escrita. }\end{array}$ \\
\hline 13 (J.) & $\begin{array}{l}\text { Explica como jogou, utilizando-se da } \\
\text { escrita. } \\
\text { Expõe o problema: Tinha uma } \\
\text { menina que queria desistir porque } \\
\text { caiu. }\end{array}$ \\
\hline 14 (J.B.) & $\begin{array}{l}\text { Explica como jogou, utilizando-se da } \\
\text { escrita. }\end{array}$ \\
\hline 15 (J.P.) & $\begin{array}{l}\text { Explica com muito detalhe como } \\
\text { jogou, utilizando-se da escrita }\end{array}$ \\
\hline $16(\mathrm{~K})$. & $\begin{array}{l}\text { Explica como jogou, utilizando-se da } \\
\text { escrita. }\end{array}$ \\
\hline 17 (L.) & Explica como jogou, utilizando-se da \\
\hline
\end{tabular}




\begin{tabular}{|c|c|}
\hline & escrita. \\
\hline 18 (L.) & $\begin{array}{l}\text { Explica como jogou, utilizando-se da } \\
\text { escrita. }\end{array}$ \\
\hline 19 (L.) & $\begin{array}{l}\text { Explica como jogou, utilizando-se do } \\
\text { desenho. }\end{array}$ \\
\hline 20 (M.) & $\begin{array}{l}\text { Explica de maneira clara e com } \\
\text { muitos detalhes como jogou, } \\
\text { utilizando-se da escrita e do } \\
\text { desenho; ainda ressalta que gostou } \\
\text { que o seu grupo expôs o jogo nessa } \\
\text { aula. }\end{array}$ \\
\hline 21 (N.M.) & $\begin{array}{l}\text { Explica como jogou, utilizando-se da } \\
\text { escrita. } \\
\text { Expõe em que sentiu dificuldades: } \\
\text { Quando saltava nas partes que a } \\
\text { corda estava muito alta. }\end{array}$ \\
\hline 22 (N.C.) & $\begin{array}{l}\text { Explica de maneira clara e com } \\
\text { muitos detalhes como jogou, } \\
\text { utilizando-se da escrita e do } \\
\text { desenho. }\end{array}$ \\
\hline 23 (N.) & $\begin{array}{l}\text { Expõe: O que achei mais legal foi } \\
\text { poder escolher a melhor altura para } \\
\text { saltar. }\end{array}$ \\
\hline
\end{tabular}

\section{Observação:}

Os alunos 1 (A.B.) e 2 (B.) conseguem em seus registros identificar e expressar com mais facilidade como se joga, as regras e as dicas aprendidas na aula.

\section{Aula 20: Diário da aula}

Em sala, entreguei aos alunos os diários comentados por mim. Entreguei as folhas para produzirem o próximo registro e os alunos me entregaram seus registros. 
Fomos para a quadra. Nessa aula já havia adiantado na sala os materiais que o grupo 3 registrou que iria utilizar.

Solicitei aos componentes do grupo que pegassem os materiais para revermos juntos o jogo que haviam criado para essa aula. (prof.)

A idéia desse grupo era fazer um jogo de cada vez, pois havia quatro propostas. Sugeri que todos os jogos poderiam acontecer ao mesmo tempo; era só dividir o espaço da quadra e dividir os alunos em grupos para a prática de cada um dos jogos, devendo trocar de estação quando ouvissem o sinal. 0 grupo gostou da idéia, ajudou a escolher os espaços da quadra para montar cada estação e depois os outros alunos, sentados na arquibancada, assistiram à demonstração e explicação rápida dos integrantes do grupo 3 em cada estação.

A turma foi divida em quatro grupos. A estação 1 era a transformação do pulasela: a proposta era saltar da mesma forma no banco sueco, sendo permitido criar novas formas de saltar. Na estação 2 era necessário saltar de um arco a outro, utilizando somente uma perna para saltar, dando impulsão horizontal. Quanto à terceira estação, havia um elástico amarrado na diagonal, ou seja, um lado era mais baixo que o outro, e também era permitido criar novas formas de saltar. Já a estação 4 era a transformação do jogo mãe da rua, com vários objetos para serem saltados enquanto os alunos fugiam do pegador.

O aluno 7 (G.R.) veio conversar comigo, dizendo que a sua preocupação era não conseguir saltar no banco apoiando as mãos como no salto do pula-sela. Eu disse a ele que podia criar uma nova forma de saltar, não precisava ser 0 salto afastado do pula-sela. O aluno foi tentar fazer e eu me aproximei da estação em que ele estava. Mais uma vez disse ele que não estava conseguindo.

Eu disse ter observado que ele tentava saltar colocando a mão no banco, como era feito no salto afastado do pula-sela, e isso não era necessário, pois o grupo deixou claro que podia criar outras formas de saltar.

Porém, o que ele deveria deixar de fazer era executar o salto sem aplicar impulso, pois ele só passava a perna sobre o obstáculo. Finalizei dizendo que o importante é não parar e cumprir com o objetivo de ultrapassar, saltando o obstáculo da maneira que ele conseguia.

Ele voltou à prática e continuou tentando. 
Percebi que todos os alunos participavam com muito entusiasmo. Alguns grupos apostavam corrida na primeira estação e saltavam os bancos. Achei interessante a criação de novas regras e, além do mais, essa nova maneira de fazer não atrapalhava o cumprimento do objetivo que precisava ser alcançado.

A aluna 14 (J.B.), no salto em altura com a corda, só passava as pernas, sem saltar o obstáculo. Eu a chamei e expus o que estava acontecendo.

No final da aula percebi que os alunos estavam ficando cansados. A aluna 18 (L.), na quarta estação (mãe da rua), para não ser pega, passava por fora das linhas do jogo.

\section{Observações:}

Lembrei-me de que a 18 (L.) é uma aluna que não aceita perder e tenta fazer de tudo para ganhar, mesmo que isso a leve a burlar as regras.

Quando estava acabando a parte prática percebi avanços na aluna 11 (I.C.) e no aluno 7 (G. R.), que saltavam com mais confiança; ela se esforçava para melhorar e parece que confia no que está fazendo.

No final da aula fizemos a roda de conversa e discutimos sobre o que eles aprenderam que consideram mais importante na proposta exposta pelos grupos 1,2 e 3.

3 (C.): É necessário ter uma situação legal material, espaço, regras e amigos para a gente aprender um jogo.

19 (L.): Eu aprendi a dar impulso para saltar.

10 (I.C.): É necessário correr com velocidade para ter o impulso que a 19 (L.) falou.

7 (G.R.): A gente quando for saltar algo alto precisa pegar distância.

$4(\mathrm{~F}$.$) : A gente tem que impulsionar o corpo para cima ou para frente depende$ do salto.

22 (N.C.): Quando a gente corre conseguimos mais impulso.

Digo aos alunos: $O$ que vocês disseram é muito importante e dá para perceber que vocês aprenderam coisas bem legais nessas últimas aulas. Também quero saber se vocês se lembram o que devemos fazer quando finalizamos um salto? 10 (I.C.): Devemos dobrar os joelhos.

Pergunto: Por quê?

3 (C.): Parar não machucar o joelho. 
Falo e demonstro aos alunos: Não é só isso, é necessário flexionar os joelhos para amortecer o salto e prevenir algum problema no joelho por causa do impacto nas articulações após o salto.

O aluno 4 (F.) expôs que algumas vezes, quando terminava o salto, ele sentiu dor no joelho, e que talvez fosse porque ele não flexionava o joelho quando terminava os saltos.

\section{Aula 20: Observações da professora sobre os registros dos alunos}

Critérios de avaliação (observar se os alunos citam respostas coerentes com o que foi trabalhado em aula):

1. Como se joga o jogo proposto?

2. Quais as dificuldades encontradas? Conhece alguma dica para melhorar?

3. Houve algum tipo de problema? Como resolveu?

TABELA 17 - Aula 20 - Observações da professora

\begin{tabular}{|l|l|}
\hline 1 (A.B.) & $\begin{array}{l}\text { Desenhou com muitos detalhes os } \\
\text { jogos que executou em cada estação. }\end{array}$ \\
\hline 2 (B.) & $\begin{array}{l}\text { Escreveu com muitos detalhes os } \\
\text { jogos que executou em cada estação. } \\
\text { Cita que venceu as dificuldades para } \\
\text { saltar tentando executar as seguintes } \\
\text { dicas: Pegar velocidade e quando } \\
\text { saltar fazer o mais alto possível para } \\
\text { não bater nos obstáculos; manter o } \\
\text { equilíbrio quando terminar os saltos. }\end{array}$ \\
\hline 3 (C.) & $\begin{array}{l}\text { Escreveu com muitos detalhes os } \\
\text { jogos que executou em cada estação. }\end{array}$ \\
\hline 4 (F.) & $\begin{array}{l}\text { Desenhou com muitos detalhes os } \\
\text { jogos que executou em cada estação. }\end{array}$ \\
\hline 5 (F.) & $\begin{array}{l}\text { Escreveu e desenhou com muitos } \\
\text { detalhes os jogos que executou em } \\
\text { cada estação. } \\
\text { Expõe: Entendi que para ter mais }\end{array}$ \\
\hline
\end{tabular}




\begin{tabular}{|l|l|}
\hline & $\begin{array}{l}\text { impulso era só correr bem rápido e } \\
\text { que é importante amortecer a queda } \\
\text { após executar um salto. } \\
\text { Diz que gostou do fato de poder } \\
\text { escolher melhor a altura para saltar e } \\
\text { do jogo em que precisou se desviar } \\
\text { de pegadores e saltar obstáculos. }\end{array}$ \\
\hline 6 (G.B.) & $\begin{array}{l}\text { Desenhou os jogos que executou em } \\
\text { cada estação. } \\
\text { Cita: Para ter mais impulso corria bem } \\
\text { rápido. } \\
\text { Diz um problema que ocorreu na aula: } \\
\text { As pessoas paravam de fazer os } \\
\text { jogos e ficavam sentadas. }\end{array}$ \\
\hline 7 (G.R.) & \begin{tabular}{l} 
Escreveu com muitos detalhes os \\
jogos que executou em cada estação. \\
Expõe dificuldades: Fugir do pai da \\
rua; saltar os obstáculos. \\
Diz: Encontrei um jeito diferente de \\
saltar e acho que melhorei a nos \\
jogos. \\
\hline (Gesenhou com muitos detalhes as \\
estações de jogos que percorreu. \\
Diz a dificuldade encontrada: o \\
cansaço e, algumas vezes, precisei \\
parar.
\end{tabular} \\
\hline $\begin{array}{l}\text { Escreveu e desenhou com muitos } \\
\text { detalhes os jogos que executou em } \\
\text { cada estação. } \\
\text { Cita que a dica mais importante que } \\
\text { aprendeu nessa aula é saltar na altura } \\
\text { que conseguia e superar os desafios } \\
\text { sem desistir. }\end{array}$ \\
\hline
\end{tabular}




\begin{tabular}{|c|c|}
\hline 10 (I.C.) & $\begin{array}{l}\text { A aluna fez em cartolina, estabeleceu } \\
\text { relações com uma situação que } \\
\text { vivenciou no treino de G.A.; também } \\
\text { inseriu duas pesquisas, uma que } \\
\text { tratava do medo como um aliado na } \\
\text { concentração de atletas da } \\
\text { modalidade atletismo e ginástica } \\
\text { artística ao executarem saltos. A outra } \\
\text { pesquisa abordava a importância da } \\
\text { velocidade da corrida para a } \\
\text { execução de saltos em diferentes } \\
\text { modalidades esportivas. }\end{array}$ \\
\hline 11 (I.C.) & $\begin{array}{l}\text { Escreveu e desenhou com muitos } \\
\text { detalhes os jogos que executou em } \\
\text { cada estação. } \\
\text { Cita: Tive que se esforçar bastante } \\
\text { para dar conta de fazer todos os jogos } \\
\text { propostos nas estações. }\end{array}$ \\
\hline 12 (J.) & $\begin{array}{l}\text { Escreveu e desenhou com muitos } \\
\text { detalhes os jogos que executou em } \\
\text { cada estação. } \\
\text { Cita que nos jogos a dica mais } \\
\text { importante era: Pegar velocidade para } \\
\text { ter mais impulso e respeitar as regras } \\
\text { para que os jogos dessem certo. }\end{array}$ \\
\hline 13 (J.) & $\begin{array}{l}\text { Só identifica os jogos que executou } \\
\text { em cada estação. }\end{array}$ \\
\hline 14 (J.B.) & $\begin{array}{l}\text { Escreve e desenha com muitos } \\
\text { detalhes os jogos que executou em } \\
\text { cada estação. } \\
\text { Cita que sentiu dificuldades na } \\
\text { estação que tinha de saltar de um pé } \\
\text { em distância. }\end{array}$ \\
\hline
\end{tabular}




\begin{tabular}{|c|c|}
\hline 15 (J.P.) & $\begin{array}{l}\text { Escreveu com muitos detalhes os } \\
\text { jogos que executou em cada estação. } \\
\text { Trouxe uma pesquisa que aborda a } \\
\text { importância da regra para as crianças. }\end{array}$ \\
\hline $16(\mathrm{~K})$. & $\begin{array}{l}\text { Escreveu com muitos detalhes os } \\
\text { jogos que executou em cada estação. } \\
\text { Cita que para melhorar as } \\
\text { dificuldades para saltar usou as } \\
\text { seguintes dicas: Pegar velocidade e } \\
\text { quando saltar fazer o mais alto } \\
\text { possível para não bater nos } \\
\text { obstáculos; manter o equilíbrio } \\
\text { quando terminar os saltos. } \\
\text { Expõe um problema que enfrentou } \\
\text { com alguns amigos: Enquanto } \\
\text { esperavam na fila os colegas } \\
\text { empurravam ou cortavam a fila. }\end{array}$ \\
\hline 17 (L.) & $\begin{array}{l}\text { Escreveu sobre os jogos que } \\
\text { executou em cada estação. }\end{array}$ \\
\hline 18 (L.) & $\begin{array}{l}\text { Escreveu com detalhes os jogos que } \\
\text { executou em cada estação. } \\
\text { Diz um problema que enfrentou com } \\
\text { alguns amigos: No salto com bambolê } \\
\text { com um pé, havia alguns colegas que } \\
\text { ficavam arrastando o bambolê e } \\
\text { ficava difícil saltar. }\end{array}$ \\
\hline 19 (L.) & $\begin{array}{l}\text { Escreveu e desenhou com muitos } \\
\text { detalhes os jogos que executou em } \\
\text { cada estação. }\end{array}$ \\
\hline 20 (M.) & $\begin{array}{l}\text { Desenhou com muitos detalhes os } \\
\text { jogos que executou em cada estação. }\end{array}$ \\
\hline 21 (N.M.) & $\begin{array}{l}\text { Escreveu os jogos que executou em } \\
\text { cada estação. }\end{array}$ \\
\hline
\end{tabular}




\begin{tabular}{|l|l|}
\hline 22 (N.C.) & $\begin{array}{l}\text { Desenhou com muitos detalhes os } \\
\text { jogos que executou em cada estação. } \\
\text { Cita que as dicas mais importantes } \\
\text { foram: Pegar impulso, jogando o } \\
\text { corpo para cima ou para frente. }\end{array}$ \\
\hline 23 (N.) & $\begin{array}{l}\text { Desenhou com muitos detalhes os } \\
\text { jogos que executou em cada estação. } \\
\text { Cita que sentiu dificuldades na } \\
\text { estação que saltava o banco. }\end{array}$ \\
\hline
\end{tabular}

\section{Observações:}

Percebi que o formato da aula por meio de tarefas organizadas em circuito foi significativo para os alunos, pois na maioria dos registros essa organização e os jogos executados foram expressos com muitos detalhes.

Alguns alunos demonstram satisfação e relatam que jogaram até se cansarem. Os alunos explicitam que os problemas com relação a conflitos entre amigos diminuíram na aula.

Percebi que a maioria não registrou dificuldades ou problemas encontrados; por outro lado, a explicitação das dicas para melhorar se sobressai na maioria dos registros.

\section{Aula 21: Diário da aula}

A aula foi iniciada na sala de aula. Conversei com os alunos sobre a entrega dos registros, pois muitos ainda esqueciam o registro em casa ou mesmo nem o faziam. Disse que iria continuar deixando na sala de aula os alunos que tinham essa atitude, para realizarem a tarefa que deveria ter sido feita em casa, e ressaltei que, com eles agindo dessa forma, perdia-se muito tempo de aula prática, o que acaba prejudicando a aprendizagem dos mesmos. Novamente falei sobre a necessidade de terem mais responsabilidade e trazerem os registros feitos em casa na data certa.

Na quadra, após a exposição sobre qual seria a proposta e o objetivo da aula, que se relacionava à prática do voleio, o aluno 23 (N.) relacionou a proposta com a modalidade esportiva badminton, que também utiliza o material 
escolhido para a aula: a peteca. Perguntei aos alunos se já haviam visto esse jogo em algum lugar.

Os alunos responderam que sim e identificaram os materiais: peteca, raquete, rede e jogadores necessários para a prática dessa modalidade.

Então, perguntei: $A$ habilidade motora envolvida nesse esporte é voleio ou rebatida?

Os alunos ficaram quietos, demonstrando que não sabiam a diferença entre os dois termos. Resolvi explicar, utilizando a gesticulação para diferenciar o voleio e a rebatida. Baseando-me em GALLAHUE (2001), expliquei aos alunos que o voleio é uma forma de bater um material no ar, colocando-se sob ele, e podese utilizar as mãos, os braços, a cabeça, as pernas, os pés ou a região peitoral. É necessário ter um bom contato com o material para direcioná-lo aonde se quer que ele chegue. Já a rebatida é uma habilidade que requer um material como bastão ou raquete para atingir outro objeto ainda no ar. Os alunos identificaram o esporte voleibol para falar da habilidade voleio e o esporte tênis para lembrar onde se utiliza a rebatida.

Após essa explicação, perguntei aos alunos como praticaram o jogo que exigia o voleio nas últimas aulas. Os alunos lembraram, uns completando a fala dos outros, que quando jogaram utilizando o voleio com peteca eles precisavam volear para o colega, que tinha de se esforçar para recebê-la, uma vez que o objetivo era não deixar a peteca cair.

Eu disse aos alunos que nesta aula havia tido a idéia de propor um jogo que se aproximava do jogo que haviam feito com a peteca, mas com outro material: a bexiga.

Os alunos mostraram-se entusiasmados. Foi proposto que formassem duplas e cumprissem as mesmas regras do jogo com peteca.

Quando começaram a jogar percebi que, mesmo os alunos se esforçando para executar o jogo, havia muito vento e eles se agrupavam no canto da quadra, prejudicando também a recepção da bexiga.

Resolvi mudar a tarefa: forneci uma bexiga a cada aluno e solicitei que trabalhem individualmente.

Construímos coletivamente outras regras e objetivos que precisavam ser atingidos, agora não mais em dupla e sim individualmente:

- trabalhar o voleio, utilizando a bexiga individualmente; 
- não parar durante a atividade;

- não deixar a bexiga cair;

- não segurar a bexiga nem usar somente os membros inferiores para voleá-la;

- esforçar-se para se superar e melhorar as dificuldades. (professora)

Os alunos voltaram à prática.

As alunas 10 (I.C.) e 14 (J.B.) disseram que não gostaram que o jogo em dupla parasse. Expliquei a elas as dificuldades impostas pelo vento na proposta em dupla, já que ele atrapalhava a trajetória da bexiga, mandando-a longe. Ainda, pontuei que trabalhar individualmente também era importante para descobrir novas possibilidades de volear, pegar o tempo do material para se colocar e volear melhor.

Elas pareceram sair satisfeitas com as explicações e se puserem a praticar 0 voleio de forma individual.

Percebi que a mudança (não prevista) na tarefa de trabalhar individualmente fez com que os alunos se concentrassem mais no que estavam realizando.

No final da aula, já na roda de conversa, foi retomado que a habilidade de volear era uma das dificuldades levantadas nos registros e na auto-avaliação realizados por eles.

Perguntei: O que vocês aprenderam hoje?

6 (G.B.): Bater com a mão debaixo da bexiga.

15 (J.P.): Encaixar a mão debaixo da bexiga e bater com força.

11 (I.C.): Ir na direção da bexiga.

1 (A.B.): Colocar o seu corpo embaixo da bexiga quando viesse na sua direção.

8 (G.): Ser veloz para conseguir volear a bexiga antes que ela caísse.

A partir daí, foi exposta uma pesquisa que a aluna 18 (L.) havia trazido e ressaltou-se que as informações abordadas na pesquisa tinham a ver com 0 que eles estavam aprendendo nas aulas de Educação Física, uma vez que tratavam da importância do jogar e do brincar na infância e no processo de aprendizagem nessa fase de desenvolvimento.

Os alunos se interessaram quando viram na pesquisa que o quadro do pintor Bruegel, utilizado no início do projeto para mostrar que desde a antigüidade as crianças já jogavam, também foi utilizado na aula de Educação Física de outra escola. 
Reforcei a importância de fazer pesquisa para enriquecer seus conhecimentos, o registro e fazer relações com o que aprendem em aula.

\section{Aula 21: Observações da professora sobre os registros dos alunos}

Critérios de avaliação (observar se os alunos citam respostas coerentes com o que foi trabalhado em aula):

1. Como se joga o jogo proposto?

2. Quais as dificuldades encontradas? Conhece alguma dica para melhorar?

3. Houve algum tipo de problema? Como resolveu?

TABELA 18 - Aula 21 - Observações da professora

\begin{tabular}{|l|l|}
\hline 1 (A.B.) & $\begin{array}{l}\text { Identifica como era a atividade } \\
\text { proposta e o que precisou fazer para }\end{array}$ \\
& $\begin{array}{l}\text { realizá-la. Por meio do desenho, } \\
\text { mostra a sim mesma como jogadora, } \\
\text { a bexiga no alto, setas que } \\
\text { representam o espaço que deveria } \\
\text { percorrer para volear. }\end{array}$ \\
\hline 2 (B.) & $\begin{array}{l}\text { Escreveu como executou a atividade } \\
\text { proposta na aula. } \\
\text { Expõe o que aprendeu: Manter a } \\
\text { atenção na bexiga para voleá-la; } \\
\text { resolver os problemas sozinho; anotar } \\
\text { na agenda o registro para não se } \\
\text { esquecer de fazê-lo. }\end{array}$ \\
\hline (C.) & $\begin{array}{l}\text { Eu tenho medo do barulho que a } \\
\text { bexiga faz quando estoura, mas eu } \\
\text { tentei esquecer dessa dificuldade e } \\
\text { continuar a jogar. O problema foi o } \\
\text { vento atrapalhou o jogo em dupla, a } \\
\text { bexiga ia parar longe e não dava } \\
\text { tempo de volear antes que ela caísse. }\end{array}$ \\
\hline \begin{tabular}{l} 
Não fez. \\
\hline
\end{tabular}
\end{tabular}




\begin{tabular}{|c|c|}
\hline $5(\mathrm{~F})$. & Não fez. \\
\hline 6 (G.B.) & $\begin{array}{l}\text { Expõe que a dica mais importante } \\
\text { dessa atividade era volear com força } \\
\text { a bexiga para cima. }\end{array}$ \\
\hline 7 (G.R.) & Não fez. \\
\hline 8 (G.) & Não fez. \\
\hline 9 (I.) & $\begin{array}{l}\text { Escreveu como executou a atividade } \\
\text { proposta na aula e ainda expôs que a } \\
\text { bexiga era um material mais fácil de } \\
\text { ser voleado. } \\
\text { Expõe por meio do desenho que a } \\
\text { dica é bater na bexiga, empurrando-a } \\
\text { para cima. }\end{array}$ \\
\hline 10 (I.C.) & Não fez. \\
\hline 11 (I.C.) & $\begin{array}{l}\text { Desenhou como executou a atividade } \\
\text { proposta na aula. } \\
\text { Expõe a dica: Saltar se fosse preciso } \\
\text { para conseguir volear a bexiga; correr } \\
\text { atrás da bexiga; prestar atenção. }\end{array}$ \\
\hline 12 (J.) & Não fez. \\
\hline 13 (J.) & Não fez. \\
\hline 14 (J.B.) & $\begin{array}{l}\text { Escreveu como executou a atividade } \\
\text { proposta na aula. } \\
\text { Expõe, por meio do desenho, que a } \\
\text { dica é manter a atenção na bexiga } \\
\text { para voleá-la, batendo-a com a palma } \\
\text { da mão. }\end{array}$ \\
\hline 15 (J.P.) & $\begin{array}{l}\text { Escreveu como executou a atividade } \\
\text { proposta na aula. } \\
\text { Expõe as dicas: Colocar a mão } \\
\text { debaixo da bexiga e empurrar com a } \\
\text { palma das mãos para volear bem; na } \\
\text { atividade individual é necessário }\end{array}$ \\
\hline
\end{tabular}




\begin{tabular}{|l|l|}
\hline & $\begin{array}{l}\text { pensar que estamos jogando com nós } \\
\text { mesmos. }\end{array}$ \\
\hline 16 (K.) & Não fez. \\
\hline 17 (L.) & Não fez. \\
\hline 18 (L.) & $\begin{array}{l}\text { Obs.: A aluna trouxe uma maquete } \\
\text { numa caixa de sapato e bilhetinhos } \\
\text { que explicavam como jogou. } \\
\text { Expõe a dica: Não ficar parado para } \\
\text { volear, é necessário se deslocar até a } \\
\text { bexiga. } \\
\text { Problema: Não conseguia volear para } \\
\text { o colega por causa do vento. Isso foi } \\
\text { resolvido mudando o jogo em dupla } \\
\text { para outro em que tinham que jogar } \\
\text { sozinhos com a bexiga. }\end{array}$ \\
\hline 19 (L.) & $\begin{array}{l}\text { Expõe a dica: Colocar a mão debaixo } \\
\text { da bexiga e empurrar com a palma } \\
\text { das mãos para volear bem. }\end{array}$ \\
\hline 22 (Mão fez. \\
\hline 21 (N.M.) & $\begin{array}{l}\text { Não fez. } \\
\text { Não fez. }\end{array}$ \\
\hline $\begin{array}{l}\text { Diz: Senti dificuldades para receber } \\
\text { bexiga e volear por causa do vento, } \\
\text { mas isso foi resolvido mudando o jogo } \\
\text { em dupla para outro que a gente } \\
\text { jogou sozinho. }\end{array}$ \\
\hline 20
\end{tabular}

\section{Observações:}

Achei interessante que alguns alunos, mesmo eu não tendo solicitado que melhorassem o registro, me mostraram o registro melhorado, baseando-se nos comentários que eu fazia; 11 (I.C.) é uma aluna que faz questão de fazer isso. 
Onze alunos não fizeram o registro dessa aula. Um fato curioso foi que a aula não foi exatamente 0 que havia planejado por causa dos problemas que 0 vento acarretou ao utilizar a bexiga.

Percebo nos registros que, para os alunos, estabelecer relações com outras informações de fora da escola é uma tarefa difícil. Essa dificuldade ocorre talvez porque não conseguem entender a importância de buscar outras informações para ampliar seus conhecimentos sobre os conteúdos propostos em aula.

Outro fato interessante foi que o portfólio despertou em alguns pais, como a mãe da aluna 18 (L.), a do aluno 12 (J.) e a da aluna 9 (I.), interesse pelo que seus filhos estavam aprendendo em Educação Física. A mãe da aluna 17 (L.) me enviava bilhetes elogiando o trabalho, dizia que a filha mostrava-se motivada e que ela auxiliava a aluna nas pesquisas. A mãe do aluno 12 (J.) me enviava bilhetes algumas vezes em que o filho não realizava o registro, e relatava o que ele não havia entendido. Já a mãe da aluna 9 (I.) me procurou para entender a nota com que a filha tinha ficado no primeiro semestre.

\section{Aula 22: Diário da aula}

Essa aula teve início na sala de leitura. Com os alunos sentados em roda, eu apresentei a eles uma lista que havia feito de impressões sobre alguns problemas que estavam acontecendo, que abarcava as seguintes necessidades:

1. cumprir com as datas de entrega do diário;

2. cumprir com os critérios determinados para a produção dos registros diários;

3. saber ouvir, prestar atenção nas discussões e explicações dadas durante a aula.

Ainda expliquei quanto essas atitudes prejudicavam seu processo de aprendizagem e mais uma vez falamos sobre a importância do registro e da auto-avaliação.

Nessa aula a aluna 22 (N.C.) trouxe o registro em cartaz e a aluna 10 (I.C.) trouxe em maquete. Pedi às alunas para mostrarem aos amigos na roda de conversa como haviam feito seu registro, para eles terem contato com novas formas de registrar. 
Eu também havia tido contato nas últimas aulas com duas pesquisas importantes para o conteúdo da turma, trazidas pelas alunas 18 (L.) e 15 (J.P.). Eu comentei com os alunos as partes mais importantes.

Essa parte da aula foi importante para os alunos porque ressaltou que buscar outros conhecimentos e ser criativo para produzir seu registro aumentava e melhorava o que haviam aprendido.

Novamente expus as metas para melhorar que havia apresentado, após a primeira coleta do portfólio. Nós identificamos nesse cartaz o que já tinha melhorado e o que precisava ser melhorado.

Depois disso, propus que criássemos juntos o jogo que iriam executar nessa aula. Iniciamos pontuando que a habilidade que precisava melhorar era 0 voleio. Listamos os materiais que poderiam ser usados para trabalhar essa habilidade: bexigas, bolão, bolas de borracha, cordas e petecas.

Os alunos lembraram que, com tantos materiais, seria possível montar vários jogos. Sugeriram que montássemos a aula em formato de circuito e utilizaram as idéias de atividades e jogos propostos nas aulas anteriores.

Com as sugestões foram montadas quatro estações com jogos e atividades diferentes:

1. voleio com bexiga, individualmente;

2. voleio com bolão, em roda: a regra é não deixar o bolão cair, e os alunos anotavam a quantidade de voleios que faziam até que a bola fosse ao chão;

3. voleio com peteca: a regra é não deixar a peteca cair, e os alunos anotavam quantas vezes a deixaram cair para depois comparar com as outras duplas e ver quem deixou cair menos vezes;

4. voleio após um pingo, em dupla, com bolas de borracha e com corda elástica fazendo o papel de rede: a cada vez que não conseguiam pegar a bola era ponto para o outro colega.

Os alunos ajudaram a construir algumas regras, que ficaram da seguinte maneira:

1. não invadir o espaço de cada um dos jogos;

2. o bolão deveria ser passado por todos na roda;

3. não era permitido falar mal do amigo, e sim ajudá-lo;

4. não podia parar de praticar os jogos porque sentiu dificuldade ou por preguiça; 
5. conversar para resolver os problemas com o amigo.

Sobrou um pouco de tempo na aula e descemos à quadra para testar esses jogos. Montamos as estações, mas os alunos jogaram pouco tempo. Porém, foi importante essa prévia para observarmos que faltavam algumas regras, como:

a) no bolão, os alunos não deveriam sair do círculo central da quadra nem ficar parados esperando a bola chegar; deveriam buscar o mais rápido possível o bolão quando ele saísse do espaço do jogo;

b) nas bexigas, os alunos não podiam ficar parados; deveriam volear o tempo todo e tentar executar outros desafios de voleio com o material, ou seja, tentar volear cada vez mais forte e alto;

c) na peteca, era necessário volear ajudando o amigo, fazendo de tudo para que o material chegasse até ele, e quem recebia não deveria ficar parado, além de não ser permitido chutar o material;

d) nas duplas com bola de borracha, os alunos deveriam buscar a bola mais rápido, não ficar parados, tentar volear direto sem ficar segurando a bola por muito tempo.

Combinamos que na próxima aula iríamos repetir o mesmo circuito.

\section{Observações:}

Percebi que construir junto com os alunos a aula, atuando como escriba, possibilitou a troca de idéias, produziu discussões valiosas sobre o que é relevante ou não na prática de jogar com a peteca.

\section{Aula 22: Observações da professora sobre os registros dos alunos}

Critérios de avaliação (observar se os alunos citam respostas coerentes com o que foi trabalhado em aula):

1. Como se joga o jogo proposto?

2. Quais as dificuldades encontradas? Conhece alguma dica para melhorar?

3. Houve algum tipo de problema? Como resolveu? 
TABELA 19 - Aula 22 - Observações da professora

\begin{tabular}{|l|l|}
\hline 1 (A.B.) & Não fez. \\
\hline 2 (B.) & $\begin{array}{l}\text { Desenha e escreve identificando os } \\
\text { jogos realizados em cada estação. } \\
\text { Ainda diz que com esses jogos o } \\
\text { objetivo era melhorar o voleio. }\end{array}$ \\
\hline 3 (C.) & $\begin{array}{l}\text { Desenha e escreve na folha sulfite e } \\
\text { em cartolina, identificando as regras e } \\
\text { os objetivos dos jogos propostos. } \\
\text { Cita que sentiu algumas dificuldades } \\
\text { para volear os materiais. }\end{array}$ \\
\hline 4 (F.) & $\begin{array}{l}\text { Desenha e escreve identificando os } \\
\text { jogos realizados em cada estação. } \\
\text { Ainda diz que com esses jogos o } \\
\text { objetivo era melhorar o voleio. Expõe } \\
\text { que o jogo de que mais gostou foi o } \\
\text { voleio em dupla com bola de } \\
\text { borracha. } \\
\text { Diz que esse jogo foi aquele em que } \\
\text { mais sentiu dificuldade, pois a bola de } \\
\text { borracha é um material que volta } \\
\text { rápido e é difícil de volear direto. }\end{array}$ \\
\hline 5 (G.) & $\begin{array}{l}\text { Desenha e escreve identificando as } \\
\text { regras e objetivo dos jogos } \\
\text { propostos. } \\
\text { Diz que sua dificuldade para volear foi } \\
\text { diminuída tentando pôr em prática as } \\
\text { seguintes dicas: Eu tentei correr atrás } \\
\text { do material e volear na direção do } \\
\text { amigo. }\end{array}$ \\
\hline Não fez. \\
Não fez. \\
Desenha identificando os jogos
\end{tabular}




\begin{tabular}{|c|c|}
\hline & propostos em cada estação. \\
\hline 9 (I.) & $\begin{array}{l}\text { Desenha e escreve identificando as } \\
\text { regras e o objetivo dos jogos das } \\
\text { duas primeiras estações (voleio com } \\
\text { bexiga e voleio com bolão). As outras } \\
\text { duas (com peteca e bolas de } \\
\text { borracha) só desenhou, mas também } \\
\text { está claro como jogou. }\end{array}$ \\
\hline 10 (I.C.) & $\begin{array}{l}\text { A aluna trouxe em maquete com os } \\
\text { jogadores e a bexiga feita de } \\
\text { massinha a representação das } \\
\text { estações de jogos e os alunos } \\
\text { executando esses jogos. Foi } \\
\text { solicitado que a aluna explicasse o } \\
\text { registro em sala e a maquete foi } \\
\text { fotografada para que o registro fosse } \\
\text { inserido na pasta do portfólio. }\end{array}$ \\
\hline 11 (I.C.) & $\begin{array}{l}\text { Desenha e escreve identificando as } \\
\text { regras e o objetivo dos jogos } \\
\text { propostos. } \\
\text { Diz: A dificuldade para volear foi } \\
\text { diminuída tentando por em prática as } \\
\text { seguintes dicas: se o voleio é sozinho } \\
\text { deve deixar a mão perto para bater } \\
\text { novamente no objeto; se o voleio for } \\
\text { feito em dupla é necessário ir até o } \\
\text { objeto e volear mirando no colega. }\end{array}$ \\
\hline 12 (J.) & $\begin{array}{l}\text { Desenha identificando os jogos } \\
\text { propostos em cada estação. }\end{array}$ \\
\hline 13 (J.) & $\begin{array}{l}\text { Desenha apresentando as dicas: } \\
\text { olhar para o objeto, ficar de frente } \\
\text { para o amigo que vai volear ou que irá } \\
\text { receber o voleio, pôr a mão embaixo }\end{array}$ \\
\hline
\end{tabular}




\begin{tabular}{|c|c|}
\hline & $\begin{array}{l}\text { do balão e volear na direção do } \\
\text { amigo. }\end{array}$ \\
\hline 14 (J.B.) & $\begin{array}{l}\text { Escreve identificando os jogos } \\
\text { propostos em cada estação. }\end{array}$ \\
\hline 15 (J.P.) & $\begin{array}{l}\text { Escreve ressaltando que os jogos } \\
\text { foram construídos de forma coletiva e } \\
\text { identifica as regras e o objetivo dos } \\
\text { jogos propostos em cada estação. } \\
\text { Diz que suas dificuldades para volear } \\
\text { foram diminuídas tentando pôr em } \\
\text { prática a dica: Tentar volear usando o } \\
\text { meio da mão para bater o objeto } \\
\text { [bola, bexiga ou peteca]. }\end{array}$ \\
\hline $16(\mathrm{~K})$. & $\begin{array}{l}\text { Escreve apresentando as dicas: Tem } \\
\text { que fazer de tudo para não deixar a } \\
\text { bola, peteca ou bexiga cair, a gente } \\
\text { tem que ver onde vai o objeto quando } \\
\text { for receber. }\end{array}$ \\
\hline 17 (L.) & $\begin{array}{l}\text { Escreve apresentando a dica: Se o } \\
\text { voleio é com dupla agente tem que ir } \\
\text { até o objeto e volear mirando no } \\
\text { colega, se esforçar para o cansaço } \\
\text { não deixar a gente parar de jogar. }\end{array}$ \\
\hline 18 (L.) & $\begin{array}{l}\text { Escreve ressaltando que } \\
\text { relembramos os objetivos já atingidos } \\
\text { e aqueles que faltam ser alcançados } \\
\text { que os jogos foram construídos de } \\
\text { forma coletiva e identifica as regras e } \\
\text { como se realiza cada um dos jogos } \\
\text { propostos. } \\
\text { Diz: A dificuldade para volear foi } \\
\text { diminuída ao tentar volear usando o } \\
\text { meio da mão para bater na bola, }\end{array}$ \\
\hline
\end{tabular}




\begin{tabular}{|c|c|}
\hline & $\begin{array}{l}\text { bexiga ou peteca; usar os dedos para } \\
\text { direcionar o voleio com a bola de } \\
\text { borracha e não ficar parado. }\end{array}$ \\
\hline 19 (L.) & $\begin{array}{l}\text { Desenha e escreve identificando as } \\
\text { regras e o objetivo dos jogos } \\
\text { propostos, inserindo o recurso de } \\
\text { setas para explicitar como jogou em } \\
\text { cada estação. } \\
\text { Desenha representando as dicas: a } \\
\text { bexiga deve ser voleada batendo a } \\
\text { palma da mão, volear sempre de } \\
\text { frente para o amigo, ver aonde a bola } \\
\text { vai. }\end{array}$ \\
\hline 20 (M.) & $\begin{array}{l}\text { Escreve ressaltando que } \\
\text { relembramos os objetivos já atingidos } \\
\text { e aqueles que falta serem } \\
\text { alcançados. }\end{array}$ \\
\hline 21 (N.M.) & $\begin{array}{l}\text { Escreve ressaltando que } \\
\text { relembramos os objetivos já atingidos } \\
\text { e aqueles que falta serem } \\
\text { alcançados. Explica os jogos e utiliza- } \\
\text { se também do desenho. } \\
\text { Expõe que teve dificuldade em volear } \\
\text { a peteca. } \\
\text { Diz que houve problemas na } \\
\text { formação dos grupos, mas depois } \\
\text { isso foi resolvido. }\end{array}$ \\
\hline 22 (N.C.) & $\begin{array}{l}\text { A aluna trouxe em cartaz a } \\
\text { representação das estações de jogos. } \\
\text { Desenha representando a dica: volear } \\
\text { mirando no amigo que receberá o } \\
\text { objeto. } \\
\text { No seu cartaz, ainda, trouxe uma }\end{array}$ \\
\hline
\end{tabular}




\begin{tabular}{|l|l|}
\hline \multicolumn{1}{|l}{} & $\begin{array}{l}\text { pesquisa em que inseriu fotos de um } \\
\text { goleiro de futebol e um jogador de } \\
\text { tênis para representar o voleio. } \\
\text { Observei um erro conceitual: as } \\
\text { figuras trazidas representavam duas } \\
\text { habilidades diferentes: a primeira o } \\
\text { voleio e a segunda a rebatida. }\end{array}$ \\
\hline $23(\mathrm{~N})$. & $\begin{array}{l}\text { Escreve identificando os jogos } \\
\text { propostos em cada estação. }\end{array}$ \\
\hline
\end{tabular}

\section{Observações:}

Nessa aula apareceram registros que impressionaram pela organização das idéias expostas. Os alunos relataram as estratégias escolhidas por seu grupo no jogo, as dicas para melhorar e os problemas que enfrentaram com os colegas. Percebe-se que usam com mais tranqüilidade a escrita e o desenho; alguns até se arriscam a utilizar outras formas de registro, como cartazes, colagem, pesquisas e maquetes. Eu considero que os alunos estão começando entender a proposta, pois eles começaram a demonstrar que a prática dos registros é uma forma de sistematizar o que aprenderam e aquilo em que sentem dificuldade.

Os registros apontam que os alunos foram desenvolvendo algumas habilidades ao longo do projeto, como refletir sobre o que fazem e expor o que pensam.

Melhorou a qualidade de sua participação em aula, opinando e sabendo ouvir nos momentos de discussão em grupo.

Desse modo, o que expõe PERRENOUD (1999) sobre a importância da observação junto à regulação no processo de avaliação formativa auxilia o aluno a pensar sobre o que está aprendendo, o que fazer para antecipar os erros ou melhorar suas dificuldades. (prof.)

\section{Aula 23: Diário da aula}

Em sala, entreguei os diários dos alunos e lembrei a responsabilidade de melhorar com relação à entrega da tarefa de organizar agora o portfólio em casa. 
O projeto está chegando ao fim e algo que está me preocupando é como fazer para que os alunos participem da produção do livro de jogos que será o produto final do projeto.

Na quadra perguntei aos alunos: Vocês sabem me dizer por que vamos repetir o circuito de jogos da aula passada?

14 (J.B.): Porque na última aula passamos muito tempo construindo os jogos em sala e jogamos pouco.

Pergunto: Vocês lembram como construímos os jogos?

10 (I.C.): Construímos juntos, alunos e a professora.

Eu disse aos alunos: Vocês apontaram o porquê de retomá-los, mas faltou dizer que eles ajudam a atingir alguns objetivos que precisam ser melhorados pelo grupo, como volear melhor, respeitar mais as regras, ter mais atenção e se concentrar mais na aula.

Os alunos montaram cada estação e iniciaram a prática do circuito. Após certo tempo de prática percebi que alguns grupos jogavam desrespeitando regras que já havíamos discutido e combinado, como, por exemplo, o espaço do jogo da sua estação, atrapalhando outros grupos. Também chutavam materiais, como bolas e petecas; ficavam com o bolão parado muito tempo nas mãos; passavam na frente do amigo para volear o bolão sem esperar sua vez.

Confesso que fiquei surpresa com essas atitudes dos alunos; não imaginava que iriam esquecer tão rápido as regras combinadas na última aula. Isso demonstra que cada um dos jogos deveria ser explicado com calma, o que não aconteceu, pois achei que podia confiar na memória dos alunos e não retomar explicações sobre como se joga.

Resolvi conversar com um grupo de cada vez para expor novamente as regras que havíamos combinado, e pontuei que da forma como estavam realizando os jogos do circuito não seriam atingidos os objetivos que precisavam melhorar.

Percebi que após a intervenção os alunos melhoraram, pois passaram a respeitar as regras e não atrapalhar os amigos. (prof.)

No final da aula, combinamos que, como já haviam registrado como se joga, eles deveriam focar a atenção sobre o que perceberam que melhoraram ou as dificuldades encontradas com relação aos objetivos que precisavam atingir (volear melhor, respeitar mais as regras, ter mais atenção e se concentrar mais 
na aula) e também no que diz respeito aos problemas que aconteceram nessa aula e como foram resolvidos.

1 (A.B.): Eu posso desenhar o que acho que já melhorei na aula de hoje e o que acho que preciso melhorar?

Eu respondo: É claro que sim, mas é importante deixar claro o que você melhorou e o que você acha que precisa melhorar.

Disse aos alunos para pensarem com calma antes de registrar o que combinamos na aula.

\section{Aula 23: Observações da professora sobre os registros dos alunos}

Critérios:

1. Como se joga?

2. O fazer para melhorar a voleio no jogo?

3. Houve problemas com os amigos?

4. Como resolveu problemas com os amigos?

TABELA 20 - Aula 23 - Observações da professora

\begin{tabular}{|l|l|}
\hline 1 (A.B.) & $\begin{array}{l}\text { Explica como jogou em cada estação. } \\
\text { Expõe as dicas para melhorar o } \\
\text { voleio: } A \text { bexiga deve ser voleada } \\
\text { batendo a palma da mão, volear } \\
\text { sempre de frente para o amigo, ver } \\
\text { aonde a bola vai. }\end{array}$ \\
\hline (B.) & $\begin{array}{l}\text { Explica como jogou em cada estação. } \\
\text { Expõe as dicas para melhorar o } \\
\text { voleio: } A \text { bexiga deve ser voleada } \\
\text { batendo a palma da mão, volear } \\
\text { sempre de frente para o amigo. } \\
\text { Diz que os amigos não respeitavam } \\
\text { as regras, o que foi resolvido após } \\
\text { conversa da professora com o grupo. }\end{array}$ \\
\hline 3 (C.) & $\begin{array}{l}\text { Explica como jogou em cada estação. } \\
\text { Expõe as dicas para melhorar o }\end{array}$ \\
\hline
\end{tabular}




\begin{tabular}{|c|c|}
\hline & $\begin{array}{l}\text { voleio: A bexiga deve ser voleada } \\
\text { batendo a palma da mão, volear } \\
\text { sempre de frente para o amigo. }\end{array}$ \\
\hline $4(F)$. & $\begin{array}{l}\text { Explica como jogou em cada estação. } \\
\text { Expõe as dicas para melhorar o } \\
\text { voleio: A bexiga deve ser voleada } \\
\text { batendo a palma da mão, volear } \\
\text { sempre de frente para o amigo, ver } \\
\text { aonde a bola, peteca ou bexiga vai. }\end{array}$ \\
\hline $5(\mathrm{~F})$. & $\begin{array}{l}\text { Explica como jogou em cada estação. } \\
\text { Expõe as dicas para melhorar o } \\
\text { voleio: A bexiga deve ser voleada } \\
\text { usando a palma da mão, volear } \\
\text { sempre de frente para o amigo. } \\
\text { Aponta que alguns amigos não } \\
\text { respeitavam as regras e expõe: } \\
\text { Tentamos conversar com a ajuda da } \\
\text { professora do grupo com estes } \\
\text { alunos. }\end{array}$ \\
\hline 6 (G.B.) & $\begin{array}{l}\text { Expõe a dica para melhorar o voleio: } \\
\text { Volear sempre de frente para } 0 \\
\text { amigo. }\end{array}$ \\
\hline 7 (G.R.) & Explica como jogou em cada estação. \\
\hline 8 (G.) & Explica como jogou em cada estação. \\
\hline 9 (I.) & $\begin{array}{l}\text { Explica como jogou em cada estação. } \\
\text { Expõe a dica para melhorar o voleio: } \\
\text { Ficar sempre de frente para o amigo. } \\
\text { Muitos não respeitavam as regras e } \\
\text { resolveu conversando com ele. }\end{array}$ \\
\hline 10 (I.C.) & $\begin{array}{l}\text { Explica como jogou em cada estação. } \\
\text { Expõe as dicas para melhorar o } \\
\text { voleio: Volear a bexiga com a palma } \\
\text { da mão, ficar de frente para o amigo. }\end{array}$ \\
\hline
\end{tabular}




\begin{tabular}{|c|c|}
\hline & $\begin{array}{l}\text { Tinha gente que não respeitava as } \\
\text { regras e resolvi conversando com ele. }\end{array}$ \\
\hline 11 (I.C.) & $\begin{array}{l}\text { Explica como jogou em cada estação. } \\
\text { Expõe as dicas para melhorar o } \\
\text { voleio: Volear batendo a palma da } \\
\text { mão, ficar de frente para o amigo. } \\
\text { Alguns alunos que não respeitava as } \\
\text { regras e melhoramos depois de } \\
\text { conversar com a professora e o } \\
\text { grupo. }\end{array}$ \\
\hline $12(\mathrm{~J})$. & $\begin{array}{l}\text { Explica como jogou em cada estação. } \\
\text { Expõe a dica para melhorar o voleio: } \\
\text { A bexiga tem que ser voleada } \\
\text { batendo a palma da mão. }\end{array}$ \\
\hline $13(\mathrm{~J})$. & $\begin{array}{l}\text { Explica como jogou em cada estação. } \\
\text { Expõe as dicas para melhorar o } \\
\text { voleio: Volear batendo com a palma } \\
\text { da mão e ficar sempre de frente para } \\
\text { o amigo. } \\
\text { Tinha amigos que não respeitava as } \\
\text { regras e foi resolvido após conversa } \\
\text { da professora com o grupo. }\end{array}$ \\
\hline 14 (J.B.) & $\begin{array}{l}\text { Explica como jogou em cada estação. } \\
\text { Expõe a dica para melhorar o voleio: } \\
\text { Volear batendo com a palma da mão } \\
\text { na bexiga. }\end{array}$ \\
\hline 15 (J.P.) & $\begin{array}{l}\text { Explica como jogou em cada estação. } \\
\text { Expõe a dica para melhorar o voleio: } \\
\text { Usar a palma da mão. }\end{array}$ \\
\hline $16(\mathrm{~K})$. & $\begin{array}{l}\text { Explica como jogou em cada estação. } \\
\text { Expõe a dica para melhorar o voleio: } \\
\text { Ficar sempre de frente para o amigo. }\end{array}$ \\
\hline 17 (L.) & Explica como se joga em cada \\
\hline
\end{tabular}




\begin{tabular}{|l|l|}
\hline & estação. \\
\hline 18 (L.) & Explica como jogou em cada estação. \\
\hline 20 (M.) & Explica como jogou em cada estação. \\
& $\begin{array}{l}\text { Explica como jogou em cada estação. } \\
\text { Expõe a dica para melhorar o voleio: } \\
\text { Volear batendo a palma da mão. }\end{array}$ \\
\hline 21 (N.M.) & $\begin{array}{l}\text { Explica como se joga em cada } \\
\text { estação. } \\
\text { Expõe a dica para melhorar o voleio: } \\
\text { Deve volear com a palma da mão. }\end{array}$ \\
\hline 22 (N.C.) & $\begin{array}{l}\text { Explica como jogou em cada estação. } \\
\text { Expõe as dicas para melhorar o } \\
\text { voleio: Volear batendo a palma da } \\
\text { mão e ficar de frente para o amigo. }\end{array}$ \\
\hline 23 (N.) & Explica como jogou em cada estação. \\
\hline
\end{tabular}

\section{Observação:}

Percebe-se que nos registros desse dia os alunos deram um grande destaque para os problemas de falta de respeito às regras que ocorreram no início da aula.

\section{Aula 24: Diário da aula}

Planejei essa aula num formato mais teórico porque, quando recebi os registros da aula anterior, percebi que o da aluna 22 (N.C.) possibilitava fazer relações com o que os alunos haviam aprendido até o momento com o projeto, bem como outras pesquisas trazidas pelos alunos, que optei utilizar nessa aula porque auxiliavam a retomar a rota percorrida, até então, com o projeto proposto.

Logo que entrei na sala de aula, solicitei um aluno para me ajudar a entregar a folha em branco para produção do registro daquela aula com tarefa de casa, e entregar o registro da última aula.

Eu chamei a aluna 22 (N.C.), abri seu cartaz e solicitei que me explicasse algumas coisas que eu não havia entendido em seu registro. 
Disse a ela que achei muito legal a sua iniciativa de inserir pesquisas com figuras em seu registro, pois a pesquisa ajuda a aprender mais e melhor os conhecimentos ensinados em aula. Ainda com relação às pesquisas, disse a ela que fiquei curiosa para saber um pouco mais sobre qual era a habilidade que o tenista estava executando: era voleio ou rebatida?

Primeiro a aluna respondeu que era voleio, mas logo depois disse que é rebatida.

Solicitei à aluna que pensasse para tentar se lembrar das nossas discussões nas últimas aulas sobre o que é voleio e rebatida. Ela ficou parada, pensando no que responder.

Perguntei se ela se lembrava da discussão feita na roda de conversa sobre rebatida e voleio.

A aluna disse que se lembrava de que havíamos falado sobre isso, mas não recordava a diferença entre voleio e rebatida.

Eu disse que iria ajudá-la, e comecei expondo que havia falado naquela aula sobre um autor que diz que a rebatida ocorre quando há um objeto como raquete ou bastão e o batemos em outro objeto, por exemplo, uma bola ou peteca. Já o voleio é uma habilidade em que batemos num objeto usando as mãos ou qualquer outra parte do corpo (pés, cabeça, peito, coxas).

Solicitei à aluna que olhasse novamente para a figura do tenista e me respondesse que habilidade motora era aquela.

22 (N.C.): Ah, é rebatida, porque ele usa a raquete e a bolinha.

Outra questão que precisava fazer à aluna 22 (N.C.) era com relação a uma figura de jogador de futebol e a relação com algumas regras do mesmo esporte.

Perguntei à aluna: Por que você colocou a figura de um goleiro de futebol e as regras do futebol no registro?

22 (N.C.): Porque o futebol é um jogo.

Pergunto: Por que é um jogo?

22 (N.C.): Porque tem regras.

Pergunto: Qual é a diferença entre o futebol e os jogos da cultura infantil que vocês aprenderam e recriaram nas últimas aulas?

22 (N.C.): Não sei. 
Pergunto: $O$ que tem de diferente entre as regras que você trouxe do futebol e as regras dos jogos da cultura infantil que vocês aprenderam e recriaram nas últimas aulas?

22 (N.C.): São dois tipos de jogos de diferentes.

Pergunto à aluna: As regras do futebol podem ser mudadas, como vocês fizeram com os jogos que praticaram nas aulas passadas?

22 (N.C.): Não

Digo à aluna: Então, aí está a grande diferença entre o futebol e os jogos da cultura das crianças, ou seja, as regras do futebol não podem ser mudadas, elas são organizadas por uma federação internacional, a FIFA, e são iguais em qualquer parte do mundo.Já as regras dos jogos praticados pelas crianças podem ser mudadas quando sentir necessidade ou vontade.

Disse aos alunos que nessa aula iríamos retomar alguns conhecimentos importantes que eles adquiriram no decorrer do projeto, por isso a aula precisava ser naquele espaço. Utilizei o cartaz e expus o que a aluna 22 (N.C.) registrou, fazendo uma retomada do que fizeram na última aula. Depois fui para a parte da pesquisa, primeiro apontando a figura e depois perguntando aos alunos: Essa habilidade que o tenista está executando é rebatida ou voleio?

O grupo foi unânime na resposta dizendo é uma rebatida.

Perguntei: Por que não é voleio?

6 (G.B.): Porque ele está com a raquete na mão para bater na bolinha.

Disse aos alunos: Outra curiosidade interessante das figuras e informações da pesquisa trazida pela aluna 22 (N.C.) é que há no futebol um jogador que usa a habilidade de volear. Vocês sabem qual é?

6 (G.B.) e 16 (K.): É o goleiro.

Digo aos alunos: Outra curiosidade tem há ver com as regras do futebol exposta nesse registro. Eu quero saber de vocês: o futebol é um jogo ou é um esporte?

21 (N.M.): Eu acho que é mais um esporte.

6 (G.B.): É esporte porque tem regras.

Eu digo aos alunos que os jogos e os esportes têm regras, e pergunto: Qual é a diferença entre as regra dos esportes e as dos jogos que vocês praticam na escola ou nos momentos de lazer?

13 (J.): Os esportes têm muito mais regras. 
22 (N.C.): As regras dos jogos das crianças podem ser mudados, as regras dos esportes não podem ser mudadas.

Eu digo aos alunos: É isso aí, um exemplo é a Copa do Mundo. Como é que tantos jogadores de países diferentes iriam jogar se as regras não fossem as mesmas para todos?

Pergunto aos alunos: $O$ que vocês fizeram no projeto, até agora, foi jogo ou esporte?

10 (I.C.): É jogo, porque podia mudar as regras.

Fui até o painel afixado na sala de aula e relembrei, reportando-me ao mapa conceitual da primeira parte do projeto, o que haviam dito para caracterizar 0 jogo.

3 (C.): É, falamos que para ter jogo é necessário aprender bem as regras e respeitá-las senão vira bagunça.

Pego o gancho dessa discussão sobre o que é jogo e a importância das regras e aproveito para comentar uma pesquisa sobre o mesmo tema exposta em registros anteriores das alunas 15(J.P.) e 18 (L.).

Conforme ia comentando as informações contidas nessas pesquisas eu questionava os alunos sobre se isso aconteceu nas nossas aulas.

3 (C.) lembra: Uma das coisas mais legais que aprendi foi resolver os problemas que tinha sozinha.

Ainda diz que isso foi possível por causa da regra que a professora colocou em todos os jogos, que dizia que deveríamos primeiro tentar resolver os problemas por meio da conversa, só se não tivesse jeito é que deveríamos chamar a professora para ajudar.

Ressaltei que realmente eles haviam melhorado, pois a maioria conseguia resolver sozinha os problemas no jogo, mas lembrei-lhes de que é necessário continuar praticando esse tipo de atitude, não só na escola, mas em todos os outros lugares em que tiverem de resolver problemas com as pessoas.

Percebo que os alunos começam a fazer relações, principalmente quanto à importância de respeitar as regras em outros lugares:

3 (C.): No hospital tem placas com a regra não fume.

6 (G.B.): No banco não se deve entrar com metais como celular ou guardachuva. 
12 (J.): No posto de gasolina não pode deixar o motor do carro ou o celular ligado.

4 (F.): No teatro ou cinema devemos desligar o celular.

1 (A.B.): Também tem as placas de trânsito.

Perguntei aos alunos: Vocês apontaram que as regras estão presentes na nossa vida. Porque elas são tão importantes?

2 (B.): Para organizar.

Quando cheguei à pesquisa da aluna 15 (J.P.), foi possível sintetizar e confirmar o que eles haviam dito com as informações expostas.

10 (I.C.): Então, as regras nos jogos podem ser mudadas quando acharmos necessário.

6 (G.B.): Precisamos do aprendizado dos jogos para aprender que as regras precisam ser cumpridas.

3 (C.): Ajuda por exemplo a correr mais e aprender mais um monte de coisa importante dos jogos.

Digo aos alunos que quero saber outra coisa deles: Sobre os registros que estão fazendo, qual é a opinião de vocês sobre a prática de fazer registros sobre o que aprendem na aula de Educação Física?

8 (G.): Para mim foi importante aprendemos mais sobre a gente. Aprendemos a refletir um pouco sobre o que estamos fazendo e saber como melhorar.

6 (G.B.): Refletir e tentar melhorar, refletir sobre o que fizemos e como fazer para melhorar ainda mais.

3 (C.): Ajuda a ensinar para outros amigos o que estamos aprendendo. $O$ registro ajuda a agente a guardar as informações e quando esquecer é só ir lá e olhar ele.

10 (I.C.): Eu aprendi que os registros ajudam a gente a aprender mais um esporte ou jogo.

19 (L.): A gente aprende brincando e jogando na aula e depois passa para o registro.

4 (F.): Pude perceber que é errando que se aprende.

21 (N.M.): Na escola a gente aprende a importância das regras, como jogar da melhor maneira possível; na rua não.

16 (K.): Respeitar regras, jogar melhor, saber como se joga e respeitar os amigos. 
10 (I.C.): Se a gente comparar a ginástica olímpica com o jogo, ela tem muito mais regras; os jogos são mais fáceis de entender.

6 (G.B.): A gente precisa aprender e combinar bem as regras para jogar bem, saber perguntar quando não souber algo.

4 (F.): É necessário combinar quais regras valem para o jogo, senão cada um joga de um jeito.

Apresento aos alunos uma outra pesquisa, trazida pela aluna 3 (C.), que se relacionava à origem dos jogos das crianças. Lembrei que outros alunos também haviam trazido pesquisas com tema semelhante. Li em voz alta e mostrei a ilustração feita pela aluna. Retornei ao mapa conceitual exposto no painel da sala de aula e recordamos o que havia sido visto sobre o assunto em aulas anteriores e quais conhecimentos a pesquisa acrescentava.

10 (I.C.): Professora, eu cheguei à conclusão que desde que o mundo é mundo as crianças jogam.

Falo à aluna 10 (I.C.): Você tem razão. Pelo menos as pesquisas com que tivemos contato apontaram isso mesmo.

O mais interessante é que alguns dos jogos apresentados nas pesquisas aparecem até hoje na vida das crianças.

\section{Observações:}

Essa aula foi bastante importante no momento em que houve 0 estabelecimento de relações entre o que as pesquisas diziam e o que os alunos fizeram em aula.

Observo nos registros que as discussões realizadas na roda de conversa organizam as idéias, sistematizam o que os alunos aprenderam e estabelecem novas relações, pois as discussões realizadas nesses momentos da aula são sempre mencionadas por eles.

\section{Aula 25: Diário da aula}

Nessa aula percebi que precisava auxiliar os alunos na compilação, seleção e organização dos registros na pasta do portfólio.

Fomos para a sala de leitura, que não dispõe de carteiras, apenas tapetes, e os alunos sentaram em roda com todos os materiais (registros, pastas). 
Primeiro, disse que iríamos fazer uma retomada de todas as etapas do projeto. Desse modo, construí um mapa conceitual gigante, no qual, para cada etapa do projeto, inseria no esquema a colagem de pequenos cartazes, atividades realizadas pelos alunos, anotações, pesquisas comentadas e conclusões coletivas que tivemos no decorrer das aulas.

A primeira etapa do projeto já estava digitada em formato de esquema, de acordo com o que foi discutido e construído em aulas anteriores. Forneci aos alunos esse esquema para que pudessem acompanhar a leitura e explicação, para a retomada do que haviam feito no inicio do projeto.

Após essa parte, continuei a construção do esquema, inserindo os materiais já citados anteriormente para representar as etapas da segunda parte do projeto. Os alunos ficaram concentrados, prestando atenção, enquanto acontecia a construção do mapa que, no final, representou as etapas de onde haviam saído e aonde chegaram.

Após a construção e apresentação do mapa, expliquei aos alunos o que deveriam fazer para organizar o portfólio, dando uma tarefa de cada vez, pois eles estavam ansiosos para usar a pasta e organizar o portfólio. Ex.: Agora vocês devem selecionar alguns registros e organizar o que sobrou colocando um clipe; agora vocês devem guardar os registros etc.

Percebi que os alunos organizavam seus registros com cuidado e atenção, e demonstravam estar satisfeitos com os resultados do seu trabalho. Um pouco dessa atitude dos alunos se deve ao esforço e valorização que eu dava a tudo aquilo (fazer registros, refletir sobre o que aprendeu ou não e pensar sobre o que fazer para melhorar), pois o tempo todo eu ressaltava quanto estavam aprendendo e avançando com tal prática.

O espaço em que ocorreu essa aula (sala de leitura) auxiliou a manter os alunos concentrados na atividade proposta e possibilitou situações de um auxiliar o outro.

Eu ficava circulando entre os alunos e para aqueles em quem eu percebia dificuldades para entender as tarefas as intervenções foram individuais. (prof.) Os alunos que terminavam rápido as tarefas ajudavam os amigos que havia se perdido na ordem estabelecida no portfólio. Houve situações interessantes de cooperação entre os pares. (prof.) 
Vários alunos mostravam-se preocupados e perguntavam o tempo todo se estava certa ou errada a ordem do seu portfólio.

No final da aula a tarefa de casa foi o questionário de auto-avaliação.

\section{Aula 25: Observações da professora sobre a segunda coleta de portfólio dos alunos}

TABELA 21 - Resultados da segunda coleta do portfólio

\begin{tabular}{|c|c|c|}
\hline Alunos & $\begin{array}{l}\text { Portfólio } \\
\text { O que mais aprendeu? }\end{array}$ & $\begin{array}{l}\text { Portfólio } \\
\text { O que mais sentiu dificuldades? }\end{array}$ \\
\hline 1 (A.B.) & $\begin{array}{l}\text { Participar de todas as atividades } \\
\text { sem parar e correr e saltar } \\
\text { melhor. }\end{array}$ & $\begin{array}{l}\text { Não entendeu muito bem as } \\
\text { regras que mudaram nos jogos. }\end{array}$ \\
\hline 2 (B.) & $\begin{array}{l}\text { Os jogos de saltar criados pelo } \\
\text { grupo } 2 \text {. }\end{array}$ & Não teve dificuldades. \\
\hline 3 (C.) & Não fez. & Não fez. \\
\hline $4(\mathrm{~F})$. & Os vários jogos de saltar. & $\begin{array}{l}\text { Definir o que fazer no trabalho } \\
\text { em grupo. }\end{array}$ \\
\hline $5(\mathrm{~F})$. & $\begin{array}{l}\text { Fazer o trabalho em grupo e } \\
\text { transformar os jogos de voleio. }\end{array}$ & Desrespeito às regras. \\
\hline 6 (G.B.) & Fazer os registros. & Não teve dificuldades. \\
\hline 7 (G.R.) & Voleio com bola. & $\begin{array}{l}\text { Saltar da maneira que o grupo } \\
\text { pedia. }\end{array}$ \\
\hline 8 (G.) & Volear. & $\begin{array}{l}\text { Ter equilíbrio na aterrissagem } \\
\text { dos saltos. }\end{array}$ \\
\hline 9 (I.C.) & $\begin{array}{l}\text { Que voleio é diferente de } \\
\text { rebatida e pesquisar resumindo } \\
\text { as informações mais } \\
\text { importantes. }\end{array}$ & $\begin{array}{l}\text { A falta de cumprimento das } \\
\text { regras que atrapalhava os jogos. }\end{array}$ \\
\hline 10 (I.C.) & Transformar jogos. & Volear a peteca. \\
\hline 11 (I.) & Voleio com peteca. & A atenção nas explicações. \\
\hline 12 (J.) & $\begin{array}{l}\text { A possibilidade de inventar } \\
\text { regras. }\end{array}$ & Saltar em distância e em altura. \\
\hline
\end{tabular}




\begin{tabular}{|c|c|c|}
\hline 13 (J.) & Volear. & $\begin{array}{l}\text { No voleio com bolão e com } \\
\text { bexiga. }\end{array}$ \\
\hline 14 (J.B.) & Correr com mais velocidade. & Saltar. \\
\hline 15 (J.P.) & Voleio. & Nada. \\
\hline $16(\mathrm{~K})$. & Ter mais velocidade. & $\begin{array}{l}\text { O jogo que tinha que correr e } \\
\text { pular a corda. }\end{array}$ \\
\hline 17 (L.) & Voleio com peteca. & Melhorar o saltar. \\
\hline 18 (L.) & $\begin{array}{l}\text { A pesquisa sobre os jogos dos } \\
\text { pais. }\end{array}$ & $\begin{array}{l}\text { Nos saltos diz que teve medo de } \\
\text { cair e os jogos com peteca. }\end{array}$ \\
\hline 19 (L.) & Voleia melhor & Voleio com peteca. \\
\hline 20 (M.) & Melhorar os registros. & Mais impulso no saltar. \\
\hline 21 (N.C.) & $\begin{array}{l}\text { Que voleio é diferente de } \\
\text { rebatida e que pesquisar é } \\
\text { importante para ampliar os } \\
\text { conhecimentos. }\end{array}$ & $\begin{array}{llll}\text { Lembrar de colocar } & \text { os } \\
\text { problemas } & \text { quando fazia } & \text { os } \\
\text { registros. } & & & \end{array}$ \\
\hline $\begin{array}{l}22 \\
\text { (N.M.) }\end{array}$ & $\begin{array}{l}\text { Correr com mais velocidade; } \\
\text { melhorou nos saltos. }\end{array}$ & Mais impulso nos saltos. \\
\hline 23 (N.) & Jogos de voleio. & $\begin{array}{l}\text { Fazer o voleio com bexiga e } \\
\text { vento. }\end{array}$ \\
\hline
\end{tabular}

TABELA 22 - Segunda auto-avaliação e avaliação das aulas

\begin{tabular}{|l|l|l|}
\hline Alunos & \multicolumn{1}{|c|}{$\begin{array}{c}\text { Auto-avaliação } \\
\text { (Observações gerais sobre o } \\
\text { que os alunos apontam com } \\
\text { relação ao que fazer para } \\
\text { melhorar as suas dificuldades) }\end{array}$} & \multicolumn{1}{|c|}{$\begin{array}{c}\text { Avaliação das aulas } \\
\text { (realizada pelos alunos) }\end{array}$} \\
\hline 1 (A.B.) & $\begin{array}{l}\text { Organizar seu tempo para } \\
\text { fazer os registros. }\end{array}$ & $\begin{array}{l}\text { Elogia: Fazer registros. } \\
\text { Sugere: } \text { Mais aulas práticas. } \\
\text { Critica: Aulas teóricas. }\end{array}$ \\
\hline 2 (B.) & $\begin{array}{l}\text { Pegar o tempo do objeto para } \\
\text { volear. }\end{array}$ & Não fez. \\
\hline 3 (C.) & $\begin{array}{l}\text { Cumprir com todos os registros } \\
\text { e saltar num pé só. }\end{array}$ & $\begin{array}{l}\text { Elogia: O capricho da professora } \\
\text { para preparar aulas diferentes. }\end{array}$ \\
\hline
\end{tabular}




\begin{tabular}{|c|c|c|}
\hline & & Critica: Aulas teóricas. \\
\hline $4(\mathrm{~F})$. & $\begin{array}{l}\text { Organizar o tempo para fazer } \\
\text { os registros e pesquisar mais. }\end{array}$ & $\begin{array}{l}\text { Elogia: Aulas livres. } \\
\text { Critica: Aula teórica. } \\
\text { Sugere: Mais aulas práticas. }\end{array}$ \\
\hline $5(\mathrm{~F})$. & $\begin{array}{l}\text { Organizar o tempo para fazer } \\
\text { os registros e pesquisar mais. }\end{array}$ & $\begin{array}{l}\text { Elogia: Quando a prof. vê, lê e } \\
\text { comenta os registros dos alunos. } \\
\text { Sugere: Mais cooperação nos } \\
\text { trabalhos em grupo. }\end{array}$ \\
\hline 6 (G.B.) & $\begin{array}{l}\text { Melhorar nos jogos de correr } \\
\text { quando estava cansado. }\end{array}$ & $\begin{array}{l}\text { Elogia: As pessoas que gostam } \\
\text { de jogar. } \\
\text { Critica: Desrespeito às regras. } \\
\text { Sugere: Criar mais jogos. }\end{array}$ \\
\hline 7 (G.R.) & $\begin{array}{l}\text { Lembrar de fazer os registros; } \\
\text { melhorar a corrida, pondo mais } \\
\text { velocidade; saltar e colaborar } \\
\text { com os amigos no trabalho em } \\
\text { grupo. }\end{array}$ & $\begin{array}{l}\text { Elogia: Os jogos. } \\
\text { Sugere: Mais tempo para a aula. }\end{array}$ \\
\hline 8 (G.) & $\begin{array}{l}\text { Lembrar de fazer os registros; } \\
\text { voleio. }\end{array}$ & $\begin{array}{l}\text { Elogia: As aulas práticas. } \\
\text { Sugere: Jogos com materiais } \\
\text { mais diversificados. }\end{array}$ \\
\hline 9 (I.C.) & $\begin{array}{l}\text { Melhorar salto em altura e em } \\
\text { distância. }\end{array}$ & $\begin{array}{l}\text { Elogia: Transformar jogos. } \\
\text { Sugere: Mais aulas de saltar. }\end{array}$ \\
\hline 10 (I.C.) & $\begin{array}{l}\text { Melhorar o jogo peteca; } \\
\text { organizar tempo para registrar; } \\
\text { prestar atenção. }\end{array}$ & Elogia: As aulas práticas. \\
\hline 11 (I.) & Melhorar voleio. & $\begin{array}{l}\text { Elogia: A professora. } \\
\text { Sugere: Mais jogos e dança. } \\
\text { Critica: Poucas pesquisas e } \\
\text { bagunça. }\end{array}$ \\
\hline $12(\mathrm{~J})$. & Não fez. & Não fez. \\
\hline 13 (J.) & $\begin{array}{l}\text { Lembrar dos registros diários e } \\
\text { ser mais organizado. }\end{array}$ & Não fez. \\
\hline
\end{tabular}




\begin{tabular}{|c|c|c|}
\hline 14 (J.B.) & $\begin{array}{l}\text { Melhorar voleio e pesquisar } \\
\text { mais. }\end{array}$ & $\begin{array}{l}\text { Elogia: Jogos. } \\
\text { Sugere: Mais respeito às regras. } \\
\text { Critica: Brigas. }\end{array}$ \\
\hline 15 (J.P.) & Ter mais tempo para registrar. & $\begin{array}{l}\text { Elogia: Dedicação da professora. } \\
\text { Sugere: Ter mais cooperação e } \\
\text { respeito às regras. } \\
\text { Critica: Falta de atenção e } \\
\text { conversas paralelas. }\end{array}$ \\
\hline $16(\mathrm{~K})$. & $\begin{array}{l}\text { Pesquisar mais e cumprir com } \\
\text { a entrega dos registros. }\end{array}$ & $\begin{array}{l}\text { Elogia: Todas as aulas. } \\
\text { Sugere: Mais tempo de jogo. }\end{array}$ \\
\hline 17 (L.) & $\begin{array}{l}\text { Cumprir com a entrega dos } \\
\text { registros; jogos de saltar. }\end{array}$ & $\begin{array}{l}\text { Elogia: A ajuda da professora } \\
\text { aos amigos. } \\
\text { Sugere: Mais jogos } e \\
\text { brincadeiras com cordas. }\end{array}$ \\
\hline 18 (L.) & Melhorar o voleio. & $\begin{array}{l}\text { Elogia: Registros diários. } \\
\text { Sugere: Ter mais oportunidade } \\
\text { para montar jogos. } \\
\text { Critica: Conversas paralelas. }\end{array}$ \\
\hline 19 (L.) & $\begin{array}{l}\text { Organizar tempo para registrar } \\
\text { e pesquisar mais }\end{array}$ & $\begin{array}{l}\text { Elogia: Esforço da professora. } \\
\text { Sugere: Mais aulas práticas. }\end{array}$ \\
\hline 20 (M.) & $\begin{array}{l}\text { Organizar tempo para registrar } \\
\text { e cumprir com a entrega na } \\
\text { data certa. }\end{array}$ & $\begin{array}{l}\text { Elogia: Aulas práticas. } \\
\text { Sugere: Mais tempo de aula. }\end{array}$ \\
\hline 21 (N.M.) & Melhorar o impulso nos saltos. & $\begin{array}{l}\text { Elogia: Aulas práticas, as dicas } \\
\text { dadas pela professora, } \\
\text { cumprimento das regras. } \\
\text { Sugere: Ter mais jogos e menos } \\
\text { registros. }\end{array}$ \\
\hline 22 (N.C.) & $\begin{array}{l}\text { Melhorar o voleio com peteca; } \\
\text { lembrar de fazer os registros }\end{array}$ & $\begin{array}{l}\text { Elogia: Os registros diferentes e } \\
\text { as pesquisas dos amigos. }\end{array}$ \\
\hline
\end{tabular}




\begin{tabular}{|l|l|l|}
\hline $23($ N.) & diários. & Sugere: Fazer mais pesquisas. \\
& $\begin{array}{l}\text { Cumprir com as tarefas de } \\
\text { casa: os registros diários. }\end{array}$ & $\begin{array}{l}\text { Elogia: Jogos. } \\
\text { Sugere: Jogos só para meninos } \\
\text { e só para meninas. }\end{array}$ \\
\hline
\end{tabular}

\section{Observações:}

$\mathrm{Na}$ segunda coleta do portfólio, os dados mais significativos da avaliação das aulas realizada pelos alunos são: sete alunos sugerem mais aulas práticas, seis alunos elogiam a postura da professora e outros seis alunos as aulas práticas. Quanto às críticas, destacam-se três que recriminam as aulas teóricas e outras três o desrespeito às regras.

Esses dados demonstram a preferência dos alunos pelas aulas práticas, que além de serem característica da área são mais motivadoras e é uma estratégia que se diferencia daquelas escolhidas por outras disciplinas, no contexto escolar. Os elogios à postura da professora em aula são pontos positivos para a minha avaliação individual, pois assinalam o meu empenho em trabalhar buscando respeitar os alunos e envolvê-los em seu processo de aprendizagem. As críticas às aulas teóricas demonstram a resistência de alguns alunos a esse tipo de estratégia na aula de Educação Física escolar. Por outro lado, considero esse um dado que aponta aspectos que precisam ser revistos na minha prática pedagógica, pois revela a pouca significância dessas aulas para alguns e o excesso desse tipo aula no decorrer do projeto. Já as críticas à falta de respeito às regras revela que essa é uma dificuldade de alguns alunos, que apontam prejudicar a aprendizagem. Contudo, percebe-se, em relação à última avaliação, que essa dificuldade apresentou melhora no decorrer das aulas.

\section{Observações sobre o mês de agosto de 2006:}

Vale lembrar que em junho o novo projeto da turma tratava do conteúdo dança e não poderiam mais ser utilizadas as aulas desse mês para o projeto que envolvia a construção do portfólio. Sendo assim, decidi organizar minhas observações e comentários nos portfólios dos alunos e realizar a avaliação individual com eles.

No mês de agosto decidimos como ficaria o empreendimento final: a construção do livro de jogos. 
Entretanto, ao ponderar as sugestões dos alunos na avaliação da aula, que revelava $\mathrm{o}$ anseio por mais aulas práticas, comecei a pensar em uma mudança: a construção de um vídeo e não mais do livro. A construção do livro iria demandar muito tempo em sala para que as decisões e seleção de textos, e de acordo com os princípios pedagógicos seguidos precisavam ser realizados de forma coletiva. A opção pelo vídeo não deixaria esse princípio pedagógico de lado, mas não necessitaria de elaborações textuais coletivas, pois as sugestões poderiam ser verbais, filmadas e editadas posteriormente.

Foi apresentada a proposta aos alunos, expondo os motivos da mudança e pedindo a sua opinião, e eles apoiaram a proposta. Adotou-se como estratégia pedir sugestões nos momentos em que fazíamos a roda de conversa no fim da aula para a definição do sumário e do conteúdo do vídeo. A partir da sugestão dos alunos, fiz, com a ajuda de um profissional da área de edição, a seleção de imagens e a organização de títulos e pequenos textos. (prof.) 
ANEXO III - Indícios da primeira pergunta norteadora: O portfólio revelou os conhecimentos trabalhados em aula?

Síntese de conteúdos trabalhados na aula, retirados das notas de campo da professora

Aula 1:

Definições sobre o que é jogo.

Levantamento de características sobre o jogo.

TABELA 23 - Primeira pergunta norteadora - Aula 1

\begin{tabular}{|c|c|c|}
\hline Alunos & $\begin{array}{l}\text { Observações da professora sobre os } \\
\text { registros dos alunos }\end{array}$ & $\begin{array}{l}\text { Conteúdos da aula } \\
\text { identificados nos re- } \\
\text { gistros dos alunos }\end{array}$ \\
\hline $4(\mathrm{~F})$. & $\begin{array}{l}\text { Expressa uma das características levanta- } \\
\text { das sobre o jogo: Não importa perder ou } \\
\text { ganhar o legal é participar. }\end{array}$ & $\begin{array}{l}\text { Levantamento de ca- } \\
\text { racterísticas do jogo. }\end{array}$ \\
\hline $5(\mathrm{~F})$. & $\begin{array}{l}\text { Expressa características levantadas sobre } \\
\text { o jogo: Tem que saber perder ou ganhar. } 0 \\
\text { jogo pode ser mudado se nós não estiver- } \\
\text { mos gostando. }\end{array}$ & $\begin{array}{l}\text { Levantamento de ca- } \\
\text { racterísticas do jogo. }\end{array}$ \\
\hline 6 (G.B.) & $\begin{array}{l}\text { Expressa características do jogo: A gente } \\
\text { pode mudar as regras se estiver chato; } \\
\text { existem jogos parados e em movimentos; } \\
\text { pode usar ou não materiais; é muito diver- } \\
\text { tido e tem bastante movimento. }\end{array}$ & $\begin{array}{l}\text { Levantamento de ca- } \\
\text { racterísticas do jogo. }\end{array}$ \\
\hline 10 (I.C.) & $\begin{array}{l}\text { Expressa características do jogo: É essen- } \\
\text { cial na infância; podem ter objetos como a } \\
\text { queimada, ou não como o pega-pega; } \\
\text { também, é importante para o desenvolvi- } \\
\text { mento do nosso corpo. }\end{array}$ & $\begin{array}{l}\text { Levantamento de ca- } \\
\text { racterísticas do jogo. }\end{array}$ \\
\hline 14 (J.B.) & $\begin{array}{l}\text { Expressa características do jogo: Neces- } \\
\text { sita de regra; respeitar os participantes e } \\
\text { prestar atenção. }\end{array}$ & $\begin{array}{l}\text { Levantamento de ca- } \\
\text { racterísticas do jogo. }\end{array}$ \\
\hline 19 (L.) & Expressa características do jogo: Diverte & Levantamento de ca- \\
\hline
\end{tabular}




\begin{tabular}{|l|l|l|}
\hline & $\begin{array}{l}\text { as pessoas; é necessário respeitar as suas } \\
\text { regras. }\end{array}$ & racterísticas do jogo. \\
\hline 20 (M.) & $\begin{array}{l}\text { Expressa características do jogo: Respeitar } \\
\text { os participantes; esperar a sua vez de fa- } \\
\text { zer ponto. }\end{array}$ & $\begin{array}{l}\text { Levantamento de ca- } \\
\text { racterísticas do jogo. }\end{array}$ \\
\hline 21 & $\begin{array}{l}\text { Expressa características sobre o que é } \\
\text { jogo: é necessário respeitar as suas re- } \\
\text { (N.M.) }\end{array}$ & $\begin{array}{l}\text { Levantamento de ca- } \\
\text { racterísticas do jogo. }\end{array}$ \\
\hline 20 & $\begin{array}{l}\text { Expressa características do jogo: } A \text { gente } \\
\text { pode mudar as regras. }\end{array}$ & $\begin{array}{l}\text { Levantamento de ca- } \\
\text { racterísticas do jogo. }\end{array}$ \\
\hline 21 (N.) & $\begin{array}{l}\text { Expressa características do jogo: } \hat{E} \text { diver- } \\
\text { tido; tem regras que podem ser modifica- } \\
\text { das. }\end{array}$ & $\begin{array}{l}\text { Levantamento de ca- } \\
\text { racterísticas do jogo. }\end{array}$ \\
\hline
\end{tabular}

Síntese de conteúdos trabalhados na aula, retirados das notas de campo da professora

Aula 2:

Jogo pique-bandeira.

Conhecer como se joga.

Habilidades: correr e se desviar com velocidade, em espaço reduzido.

Regras: aceitar quando for pego; não ultrapassar as linhas que delimitam o espaço do jogo; respeitar que todos devem ter o direito de tentar o ponto.

TABELA 24 - Primeira pergunta norteadora - Aula 2

\begin{tabular}{|l|l|l|}
\hline Alunos & $\begin{array}{l}\text { Observações da professora sobre os } \\
\text { registros dos alunos }\end{array}$ & $\begin{array}{l}\text { Conteúdos da aula } \\
\text { identificados nos re- } \\
\text { gistros dos alunos }\end{array}$ \\
\hline 2 (B.) & $\begin{array}{l}\text { Explica o jogo pique-bandeira, } \\
\text { identificando como se joga: Os jogadores } \\
\text { quando for passar não podem deixar ser } \\
\text { pego quando for pegar a bola do outro } \\
\text { lado. Se for pego devolve a bola e volta }\end{array}$ & $\begin{array}{l}\text { Como se jogras: aceitar quando } \\
\text { bandeira. } \\
\text { for pegor, não ultra- } \\
\text { passar linhas que }\end{array}$ \\
\hline
\end{tabular}




\begin{tabular}{|c|c|c|}
\hline & $\begin{array}{l}\text { para o seu lado. } \\
\text { Expõe regra combinada: Aceitar quando } \\
\text { for pego. }\end{array}$ & $\begin{array}{l}\text { delimitam o espaço do } \\
\text { jogo e respeitar que } \\
\text { todos devem ter o di- } \\
\text { reito de tentar o ponto. }\end{array}$ \\
\hline $3(\mathrm{C})$. & $\begin{array}{l}\text { Identifica o nome do jogo que executou: } \\
\text { pique-bandeira. }\end{array}$ & \\
\hline $4(\mathrm{~F})$. & $\begin{array}{l}\text { Explica o jogo pique-bandeira, } \\
\text { identificando como se joga por meio do } \\
\text { desenho. Ele expõe os dois times } \\
\text { posicionados e por meio de setas mostra } \\
\text { o caminho percorrido por vários } \\
\text { jogadores que tentam pegar a bandeira. } \\
\text { Para os jogadores pegos no meio do } \\
\text { percurso ele insere a expressão "peguei" } \\
\text { e para o que consegue pegar a bandeira } \\
\text { e fazer ponto insere "ponto para minha } \\
\text { equipe". } \\
\text { Expõe as regras combinadas: Não ultra- } \\
\text { passar as linhas do jogo e respeitar que } \\
\text { todos devem ter o direito de tentar o } \\
\text { ponto. }\end{array}$ & $\begin{array}{l}\text { Como se joga pique- } \\
\text { bandeira. } \\
\text { Regras: aceitar quando } \\
\text { for pego, não ultra- } \\
\text { passar as linhas que } \\
\text { delimitam o espaço do } \\
\text { jogo e respeitar que } \\
\text { todos devem ter o di- } \\
\text { reito de tentar o ponto. }\end{array}$ \\
\hline $5(\mathrm{~F})$. & Identifica o nome do jogo pique-bandeira. & \\
\hline 6 (G.B.) & $\begin{array}{l}\text { Explica o jogo pique-bandeira, } \\
\text { identificando como se joga: É um jogo } \\
\text { que precisa se movimentar bastante não } \\
\text { pode passar a bola tinha que passar } \\
\text { [atravessar o campo adversário] com ela } \\
\text { nas mãos. }\end{array}$ & $\begin{array}{l}\text { Como se joga pique- } \\
\text { bandeira. }\end{array}$ \\
\hline 7 (G.R.) & $\begin{array}{l}\text { Explica o jogo pique-bandeira, } \\
\text { identificando como se joga: Tem que ter } \\
\text { agilidade e rapidez para se desviar dos } \\
\text { pegadores do outro time ou para pegar } \\
\text { os adversários que invadem nosso }\end{array}$ & $\begin{array}{l}\text { Como se joga pique- } \\
\text { bandeira. } \\
\text { Habilidades: correr e } \\
\text { se desviar com veloci- } \\
\text { dade, em espaço re- }\end{array}$ \\
\hline
\end{tabular}




\begin{tabular}{|c|c|c|}
\hline & $\begin{array}{l}\text { campo. } \\
\text { Expõe regra combinada: Respeitar que } \\
\text { todos devem ter o direito de tentar o } \\
\text { ponto. } \\
\text { Aponta as habilidades envolvidas no } \\
\text { jogo: Correr com velocidade; se desviar } \\
\text { dos pegadores. }\end{array}$ & $\begin{array}{l}\text { duzido. } \\
\text { Regras: aceitar quando } \\
\text { for pego, não ultra- } \\
\text { passar as linhas que } \\
\text { delimitam o espaço do } \\
\text { jogo e respeitar que } \\
\text { todos devem ter o di- } \\
\text { reito de tentar o ponto. }\end{array}$ \\
\hline 10 (I.C.) & $\begin{array}{l}\text { Identifica o nome do jogo que executou: } \\
\text { pique-bandeira. } \\
\text { Expõe regra combinada: Aceitar quando } \\
\text { for pego. }\end{array}$ & $\begin{array}{l}\text { Regras: aceitar quando } \\
\text { for pego, não ultra- } \\
\text { passar as linhas que } \\
\text { delimitam o espaço do } \\
\text { jogo e respeitar que } \\
\text { todos devem ter o di- } \\
\text { reito de tentar o ponto. }\end{array}$ \\
\hline 14 (J.B.) & $\begin{array}{l}\text { Explica o jogo pique-bandeira, } \\
\text { identificando como se joga: É um jogo } \\
\text { que tem que prestar atenção, ter } \\
\text { agilidade e reflexo para não ser pego e } \\
\text { tentar pegar a bandeira [no campo } \\
\text { adversário]. } \\
\text { Expõe as regras combinadas: Aceitar } \\
\text { quando for pego; não ultrapassar as } \\
\text { linhas do jogo e respeitar que todos } \\
\text { devem tero direito de tentaro ponto. } \\
\text { Aponta as habilidades envolvidas no } \\
\text { jogo: correr com velocidade; se desviar } \\
\text { dos pegadores. }\end{array}$ & $\begin{array}{l}\text { Como se joga pique- } \\
\text { bandeira. } \\
\text { Habilidades: correr e } \\
\text { se desviar com veloci- } \\
\text { dade, em espaço re- } \\
\text { duzido. } \\
\text { Regras: aceitar quando } \\
\text { for pego; não ultra- } \\
\text { passar as linhas que } \\
\text { delimitam o espaço do } \\
\text { jogo e respeitar que } \\
\text { todos devem ter o di- } \\
\text { reito de tentar o ponto. }\end{array}$ \\
\hline 15 (J.P.) & $\begin{array}{l}\text { Explica o jogo pique-bandeira, } \\
\text { identificando como se joga: Dois grupos } \\
\text { tinham que atacar o campo da outra } \\
\text { equipe e pegar a bola e levar para o seu } \\
\text { campo, mas se a pessoa te pegar você }\end{array}$ & $\begin{array}{l}\text { Como se joga pique- } \\
\text { bandeira. } \\
\text { Regras: aceitar quando } \\
\text { for pego; não ultra- } \\
\text { passar as linhas que }\end{array}$ \\
\hline
\end{tabular}




\begin{tabular}{|c|c|c|}
\hline & $\begin{array}{l}\text { vira estátua e tem que esperar alguém te } \\
\text { salvar. Acaba o jogo quando alguém leva } \\
\text { a bola até o seu campo. }\end{array}$ & $\begin{array}{l}\text { delimitam o espaço do } \\
\text { jogo e respeitar que } \\
\text { todos devem ter o di- } \\
\text { reito de tentar o ponto. }\end{array}$ \\
\hline 16 (K.) & $\begin{array}{l}\text { Explica o jogo pique-bandeira, identificando } \\
\text { como se joga: Este jogo tem que ser } \\
\text { rápido para não ser pego e perder a } \\
\text { chance de trazer a bandeira para o seu } \\
\text { campo e fazer o ponto. }\end{array}$ & $\begin{array}{l}\text { Como se joga pique- } \\
\text { bandeira. }\end{array}$ \\
\hline 17 (L.) & $\begin{array}{l}\text { Aponta as habilidades envolvidas no } \\
\text { jogo: Correr com velocidade; se desviar } \\
\text { dos pegadores para não ser pego. }\end{array}$ & $\begin{array}{l}\text { Habilidades: correr e } \\
\text { se desviar com veloci- } \\
\text { dade, em espaço re- } \\
\text { duzido. }\end{array}$ \\
\hline 18 (L.) & $\begin{array}{l}\text { Expõe as regras combinadas: Não ultra- } \\
\text { passar as linhas do jogo. } \\
\text { Aponta as habilidades envolvidas no } \\
\text { jogo: Correr com velocidade; se desviar } \\
\text { dos pegadores; }\end{array}$ & $\begin{array}{l}\text { Habilidades: correr e } \\
\text { se desviar com veloci- } \\
\text { dade, em espaço re- } \\
\text { duzido. } \\
\text { Regras: aceitar quando } \\
\text { for pego; não ultra- } \\
\text { passar as linhas que } \\
\text { delimitam o espaço do } \\
\text { jogo e respeitar que } \\
\text { todos devem ter o di- } \\
\text { reito de tentar o ponto. }\end{array}$ \\
\hline 19 (L.) & $\begin{array}{l}\text { Aponta as habilidades envolvidas no } \\
\text { jogo: Correr com velocidade; se desviar } \\
\text { dos pegadores; }\end{array}$ & $\begin{array}{l}\text { Habilidades: correr e } \\
\text { se desviar com veloci- } \\
\text { dade, em espaço re- } \\
\text { duzido. }\end{array}$ \\
\hline 20 (M.) & $\begin{array}{l}\text { Expõe as regras combinadas: Aceitar } \\
\text { quando for pego; não ultrapassar as } \\
\text { linhas do jogo. } \\
\text { Aponta as habilidades envolvidas no }\end{array}$ & $\begin{array}{l}\text { Habilidades: correr e } \\
\text { se desviar com veloci- } \\
\text { dade, em espaço re- } \\
\text { duzido. }\end{array}$ \\
\hline
\end{tabular}




\begin{tabular}{|c|c|c|}
\hline & $\begin{array}{l}\text { jogo: Correr com velocidade; se desviar } \\
\text { dos pegadores; }\end{array}$ & $\begin{array}{l}\text { Regras: aceitar quando } \\
\text { for pego; não ultra- } \\
\text { passar as linhas que } \\
\text { delimitam o espaço do } \\
\text { jogo e respeitar que } \\
\text { todos devem ter o di- } \\
\text { reito de tentar o ponto. }\end{array}$ \\
\hline 21 (N.M.) & $\begin{array}{l}\text { Explica o jogo pique-bandeira, identifi- } \\
\text { cando como se joga por meio de uma } \\
\text { pesquisa sobre o jogo, que expõe figuras } \\
\text { e explicação sobre como se joga. Além } \\
\text { disso, apresenta outras formas de } \\
\text { realizar o mesmo jogo. } \\
\text { Expõe as regras combinadas: Aceitar } \\
\text { quando for pego; respeitar que todos de- } \\
\text { vem ter o direito de tentar o ponto. } \\
\text { Aponta as habilidades envolvidas no } \\
\text { jogo: Correr com velocidade; atenção ao } \\
\text { se desviar para não ser pego. }\end{array}$ & $\begin{array}{l}\text { Como se joga pique- } \\
\text { bandeira. } \\
\text { Habilidades: correr e } \\
\text { se desviar com veloci- } \\
\text { dade, em espaço re- } \\
\text { duzido. } \\
\text { Regras: aceitar quando } \\
\text { for pego; não ultra- } \\
\text { passar as linhas que } \\
\text { delimitam o espaço do } \\
\text { jogo e respeitar que } \\
\text { todos devem ter o di- } \\
\text { reito de tentar o ponto. }\end{array}$ \\
\hline 22 (N.C.) & $\begin{array}{l}\text { Explica o jogo pique-bandeira, } \\
\text { identificando como se joga: É assim tem } \\
2 \text { times cada time tem } 1 \text { bola o time [um } \\
\text { jogador] tenta pegar a bola do outro sem } \\
\text { ser pego. }\end{array}$ & $\begin{array}{l}\text { Como se joga pique- } \\
\text { bandeira. }\end{array}$ \\
\hline
\end{tabular}

Síntese de conteúdos trabalhados na aula, retirados das notas de campo da professora

\section{Aula 3:}

Escolher dois jogos da pesquisa com os pais (alerta e futebol)

Conhecer como se praticam esses jogos (futebol com regras sintetizadas e adaptadas ao grupo). 
As habilidades do jogo alerta: passe de bola, arremesso com as mãos e correr com velocidade.

As habilidades do jogo futebol: troca de passes.

As regras: respeitar que todos devem ter a chance de receber a bola; resolver os problemas conversando.

TABELA 25 - Primeira pergunta norteadora - Aula 3

\begin{tabular}{|c|c|c|}
\hline Alunos & $\begin{array}{l}\text { Observações da professora } \\
\text { sobre os registros dos alunos }\end{array}$ & $\begin{array}{l}\text { Conteúdos da aula identifi- } \\
\text { cados nos registros dos alu- } \\
\text { nos }\end{array}$ \\
\hline 3 (C.) & $\begin{array}{l}\text { Identifica os jogos alerta e } \\
\text { futebol escolhidos na aula. }\end{array}$ & $\begin{array}{l}\text { Escolher dois jogos da pes- } \\
\text { quisa com os pais (alerta e fu- } \\
\text { tebol). }\end{array}$ \\
\hline $4(\mathrm{~F})$. & $\begin{array}{l}\text { Identifica os jogos alerta e } \\
\text { futebol escolhidos na aula. }\end{array}$ & $\begin{array}{l}\text { Escolher dois jogos da pes- } \\
\text { quisa com os pais (alerta e fu- } \\
\text { tebol). }\end{array}$ \\
\hline 6 (G.B.) & $\begin{array}{l}\text { Identifica os jogos alerta e } \\
\text { futebol escolhidos na aula. } \\
\text { Expõe como jogou alerta: Passar } \\
\text { a bola para os amigos, quando } \\
\text { caía quem pegava a bola tinha } \\
\text { que gritar "Alerta". }\end{array}$ & $\begin{array}{l}\text { Escolher dois jogos da pes- } \\
\text { quisa com os pais (alerta e fu- } \\
\text { tebol). } \\
\text { Conhecer como se praticam } \\
\text { esses jogos. }\end{array}$ \\
\hline 8 (G.) & $\begin{array}{l}\text { Identifica os jogos alerta e } \\
\text { futebol escolhidos na aula. }\end{array}$ & $\begin{array}{l}\text { Escolher dois jogos da pes- } \\
\text { quisa com os pais (alerta e fu- } \\
\text { tebol). }\end{array}$ \\
\hline 9 (I.) & $\begin{array}{l}\text { Identifica os jogos alerta e } \\
\text { futebol escolhidos na aula. } \\
\text { Como se joga alerta: Passar a } \\
\text { bola para os amigos, quando ela } \\
\text { caía, a gente corria e quem pe- } \\
\text { gava a bola gritava "Alerta". } \\
\text { Como jogou futebol: A gente } \\
\text { chutava a bola se desviando dos }\end{array}$ & $\begin{array}{l}\text { Escolher dois jogos da pes- } \\
\text { quisa com os pais (alerta e fu- } \\
\text { tebol). } \\
\text { Conhecer como se praticam } \\
\text { esses jogos (futebol com re- } \\
\text { gras sintetizadas e adaptadas } \\
\text { ao grupo). }\end{array}$ \\
\hline
\end{tabular}




\begin{tabular}{|c|c|c|}
\hline & $\begin{array}{l}\text { adversários até chegar no gol e } \\
\text { chutar. }\end{array}$ & \\
\hline 10 (I.C.) & $\begin{array}{l}\text { Identifica os jogos alerta e } \\
\text { futebol escolhidos na aula. } \\
\text { Expõe como jogou alerta: Passar } \\
\text { a bola com as mãos, se ela } \\
\text { caísse tinha que correr e parar } \\
\text { quando ouvia "Alerta". } \\
\text { Expõe como jogou futebol: A } \\
\text { gente chutava a bola se } \\
\text { desviando e passando pelos os } \\
\text { colegas. }\end{array}$ & $\begin{array}{l}\text { Escolher dois jogos da pes- } \\
\text { quisa com os pais (alerta e fu- } \\
\text { tebol). } \\
\text { Conhecer como se praticam } \\
\text { esses jogos (futebol com re- } \\
\text { gras sintetizadas e adaptadas } \\
\text { ao grupo). }\end{array}$ \\
\hline 11 (I.C.) & $\begin{array}{l}\text { Identifica os jogos alerta e } \\
\text { futebol escolhidos na aula. }\end{array}$ & $\begin{array}{l}\text { Escolher dois jogos da pes- } \\
\text { quisa com os pais (alerta e fu- } \\
\text { tebol). }\end{array}$ \\
\hline 13 (J.) & $\begin{array}{l}\text { Identifica os jogos alerta e } \\
\text { futebol escolhidos na aula. } \\
\text { Expõe como jogou alerta: } \\
\text { Passava a bola com as mãos, se } \\
\text { ela caísse corria e só parava } \\
\text { quando ouvia "Alerta". } \\
\text { Expõe como jogou futebol: Chu- } \\
\text { tava a bola até chegar no gol. } \\
\text { Expõe as regras: respeitar que } \\
\text { todos devem ter a chance de re- } \\
\text { ceber a bola e fazer ponto. }\end{array}$ & $\begin{array}{l}\text { Escolher dois jogos da pes- } \\
\text { quisa com os pais (alerta e fu- } \\
\text { tebol). } \\
\text { Conhecer como se praticam } \\
\text { esses jogos (futebol com re- } \\
\text { gras sintetizadas e adaptadas } \\
\text { ao grupo). } \\
\text { As regras: respeitar que todos } \\
\text { devem ter a chance de receber } \\
\text { a bola; resolver os problemas } \\
\text { conversando. }\end{array}$ \\
\hline 14 (J.B.) & $\begin{array}{l}\text { Identifica os jogos alerta e } \\
\text { futebol escolhidos na aula. } \\
\text { Como se executa a habilidade } \\
\text { do jogo alerta, passe de bola: } \\
\text { Ficar na frente do colega que irá } \\
\text { enviar a bola. } \\
\text { Expõe as regras: Passar a bola }\end{array}$ & $\begin{array}{l}\text { Escolher dois jogos da pes- } \\
\text { quisa com os pais (alerta e fu- } \\
\text { tebol). } \\
\text { Conhecer como se joga esses } \\
\text { jogos (futebol com regras sin- } \\
\text { tetizadas e adaptadas ao } \\
\text { grupo). }\end{array}$ \\
\hline
\end{tabular}




\begin{tabular}{|c|c|c|}
\hline & para todos do time. & $\begin{array}{l}\text { As regras: respeitar que todos } \\
\text { devem ter a chance de receber } \\
\text { a bola; resolver os problemas } \\
\text { conversando. }\end{array}$ \\
\hline $16(\mathrm{~K})$. & $\begin{array}{l}\text { Identifica os jogos alerta e } \\
\text { futebol escolhidos na aula. } \\
\text { Identifica as habilidades exigidas } \\
\text { nos jogos: chutar com mira no } \\
\text { gol, passar a bola de frente para } \\
\text { o colega. } \\
\text { Desenha os dois jogos. }\end{array}$ & $\begin{array}{l}\text { Escolher dois jogos da pes- } \\
\text { quisa com os pais (alerta e fu- } \\
\text { tebol). } \\
\text { As habilidades do jogo alerta: } \\
\text { passe de bola, arremesso com } \\
\text { as mãos e correr com veloci- } \\
\text { dade. } \\
\text { As habilidades do jogo futebol: } \\
\text { troca de passes. }\end{array}$ \\
\hline 17 (L.) & $\begin{array}{l}\text { Identifica os jogos alerta e } \\
\text { futebol escolhidos na aula. } \\
\text { Expõe como jogou alerta: } \\
\text { Passava a bola, quando ela caía } \\
\text { corria e parava quando ouvia } \\
\text { "Alerta". } \\
\text { Expõe como jogou futebol: Chu- } \\
\text { tava a bola para as colegas no } \\
\text { gol. }\end{array}$ & $\begin{array}{l}\text { Escolher dois jogos da pes- } \\
\text { quisa com os pais (alerta e fu- } \\
\text { tebol). } \\
\text { Conhecer como se praticam } \\
\text { esses jogos (futebol com re- } \\
\text { gras sintetizadas e adaptadas } \\
\text { ao grupo). }\end{array}$ \\
\hline 18 (L.) & $\begin{array}{l}\text { Identifica os jogos alerta e } \\
\text { futebol escolhidos na aula. }\end{array}$ & $\begin{array}{l}\text { Escolher dois jogos da pes- } \\
\text { quisa com os pais (alerta e fu- } \\
\text { tebol). }\end{array}$ \\
\hline 19 (L.) & $\begin{array}{l}\text { Identifica os jogos alerta e } \\
\text { futebol escolhidos na aula. }\end{array}$ & $\begin{array}{l}\text { Escolher dois jogos da pes- } \\
\text { quisa com os pais (alerta e fu- } \\
\text { tebol). }\end{array}$ \\
\hline 20 (M.) & $\begin{array}{l}\text { Identifica os jogos alerta e } \\
\text { futebol escolhidos na aula. }\end{array}$ & $\begin{array}{l}\text { Escolher dois jogos da pes- } \\
\text { quisa com os pais (alerta e fu- } \\
\text { tebol). }\end{array}$ \\
\hline 21 (N.M.) & $\begin{array}{l}\text { Identifica os jogos alerta e } \\
\text { futebol escolhidos na aula. }\end{array}$ & $\begin{array}{l}\text { Escolher dois jogos da pes- } \\
\text { quisa com os pais (alerta e fu- }\end{array}$ \\
\hline
\end{tabular}




\begin{tabular}{|c|c|c|}
\hline & & tebol). \\
\hline 22 (N.C.) & $\begin{array}{l}\text { Identifica os jogos alerta e } \\
\text { futebol escolhidos na aula. } \\
\text { Expõe como jogou: O jogo alerta } \\
\text { começava com a bola passando } \\
\text { para os amigos em roda, quando } \\
\text { caía quem pegava a bola tinha } \\
\text { que gritar "Alerta". No futebol } \\
\text { tinha que passar a bola para os } \\
\text { amigos e quando chegava perto } \\
\text { do gol tentava chutar forte para } \\
\text { fazer gol. }\end{array}$ & $\begin{array}{l}\text { Escolher dois jogos da pes- } \\
\text { quisa com os pais (alerta e fu- } \\
\text { tebol). } \\
\text { Conhecer como se praticam } \\
\text { esses jogos (futebol com re- } \\
\text { gras sintetizadas e adaptadas } \\
\text { ao grupo). }\end{array}$ \\
\hline 23 (N.) & $\begin{array}{l}\text { Identifica os jogos alerta e } \\
\text { futebol escolhidos na aula. } \\
\text { Identifica as regras: A bola deve } \\
\text { ser passada por todos. }\end{array}$ & $\begin{array}{l}\text { Escolher dois jogos da pes- } \\
\text { quisa com os pais (alerta e fu- } \\
\text { tebol). } \\
\text { As regras: respeitar que todos } \\
\text { devem ter a chance de receber } \\
\text { a bola; resolver os problemas } \\
\text { conversando. }\end{array}$ \\
\hline
\end{tabular}

Síntese de conteúdos trabalhados na aula, retirados das notas de campo da professora

\section{Aula 4:}

Hipóteses sobre a origem do jogo.

TABELA 26 - Primeira pergunta norteadora - Aula 4

\begin{tabular}{|l|l|l|}
\hline Alunos & $\begin{array}{l}\text { Observações da professora sobre os registros } \\
\text { dos alunos }\end{array}$ & $\begin{array}{l}\text { Conteúdos da } \\
\text { aula identificados } \\
\text { nos registros dos } \\
\text { alunos }\end{array}$ \\
\hline 1 (A.B.) & $\begin{array}{l}\text { Identifica algumas hipóteses sobre a origem do } \\
\text { jogo: Os jogos podem ter surgido na Grécia ou } \\
\text { em outros países. }\end{array}$ & $\begin{array}{l}\text { Hipóteses sobre } \\
\text { a origem do jogo. }\end{array}$ \\
\hline
\end{tabular}




\begin{tabular}{|c|c|c|}
\hline 2 (B.) & $\begin{array}{l}\text { Identifica algumas hipóteses sobre a origem do } \\
\text { jogo: Os jogos podem ter nascido na Espanha, } \\
\text { Portugal [Europa] ou na Grécia. }\end{array}$ & $\begin{array}{l}\text { Hipóteses sobre } \\
\text { a origem do jogo. }\end{array}$ \\
\hline 5 (F.) & $\begin{array}{l}\text { Identifica algumas hipóteses sobre a origem do } \\
\text { jogo: A professora explicou exemplos sobre de } \\
\text { onde surgiu o jogo e fez um pequeno teatro e o } \\
\text { que achei mais interessante foi saber que o jogo } \\
\text { pode ter surgido da necessidade das crianças } \\
\text { mostrarem o que queriam. [hipótese sobre a } \\
\text { origem dos jogos exposta por Freud]. }\end{array}$ & $\begin{array}{l}\text { Hipóteses sobre } \\
\text { a origem do jogo. }\end{array}$ \\
\hline 6 (G.B.) & $\begin{array}{l}\text { Identifica algumas hipóteses sobre a origem do } \\
\text { jogo: Hoje aprendemos de onde podem ter nas- } \\
\text { cido os jogos, a primeira hipótese veio dos gre- } \\
\text { gos (...); a segunda veio dos europeus apre- } \\
\text { sentam jogos desde a antiguidade, quando vie- } \\
\text { ram para o Brasil trouxeram vários jogos que } \\
\text { faziam em sua terra. A terceira hipótese é que } \\
\text { um cientista observou crianças pequenas } \\
\text { quando jogavam o carretel longe é porque a } \\
\text { mãe estava longe e quando ela estava perto } \\
\text { elas puxavam o carretel. Ele acha que o jogo } \\
\text { pode ter surgido da necessidade das crianças } \\
\text { mostrar o que sentiam. }\end{array}$ & $\begin{array}{l}\text { Hipóteses sobre } \\
\text { a origem do jogo. }\end{array}$ \\
\hline 7 (G.R.) & $\begin{array}{l}\text { Identifica algumas hipóteses sobre a origem do } \\
\text { jogo: Fizemos um teatro que representou jogos } \\
\text { antigos feitos pelos europeus, e também pale- } \\
\text { ontólogo que descobriu crianças gregas da anti- } \\
\text { guidade que foram enterradas com bonecos nas } \\
\text { mãos, e diz que os jogos podem ter surgido na } \\
\text { Grécia. }\end{array}$ & $\begin{array}{l}\text { Hipóteses sobre } \\
\text { a origem do jogo. }\end{array}$ \\
\hline 8 (G.) & $\begin{array}{l}\text { Identifica algumas hipóteses sobre a origem do } \\
\text { jogo: hoje fizemos teatros de onde surgíramos } \\
\text { jogos e existem várias hipóteses relacionadas }\end{array}$ & $\begin{array}{l}\text { Hipóteses sobre } \\
\text { a origem do jogo. }\end{array}$ \\
\hline
\end{tabular}




\begin{tabular}{|c|c|c|}
\hline & $\begin{array}{l}\text { que pode surgido na Grécia, na Europa ou atra- } \\
\text { vés dos bebês. }\end{array}$ & \\
\hline 9 (I.) & $\begin{array}{l}\text { Identifica algumas hipóteses sobre a origem do } \\
\text { jogo: A professora mostrou a } 1^{\circ} \text { hipótese de } \\
\text { onde pode ter surgido os jogos na Grécia } 4 \text { anos } \\
\text { antes de Cristo, descobriram que as crianças } \\
\text { eram enterradas com brinquedos; a } 2^{\circ} \text { é a da } \\
\text { Europa os jogos podem ter surgido lá. }\end{array}$ & $\begin{array}{l}\text { Hipóteses sobre } \\
\text { a origem do jogo. }\end{array}$ \\
\hline 10 (I.C.) & $\begin{array}{l}\text { Hoje a aula teórica foi muito legal, a professora } \\
\text { nos levou para o auditório e mostrou várias hi- } \\
\text { póteses de onde pode ter surgido os jogos na } \\
\text { Grécia, a hipótese da Europa e a de Freud. }\end{array}$ & $\begin{array}{l}\text { Hipóteses sobre } \\
\text { a origem do jogo. }\end{array}$ \\
\hline 11 (I.C.) & $\begin{array}{l}\text { A gente demonstrou com teatro as hipóteses de } \\
\text { como surgiram os jogos infantis. }\end{array}$ & \\
\hline 13 (J.) & $\begin{array}{l}\text { Os jogos podem ter surgido na Grécia antiga e } \\
\text { se espalharam pelo mundo. }\end{array}$ & $\begin{array}{l}\text { Hipóteses sobre } \\
\text { a origem do jogo. }\end{array}$ \\
\hline 14 (J.B.) & $\begin{array}{l}\text { Identifica algumas hipóteses sobre a origem do } \\
\text { jogo: A professora mostrou } 3 \text { hipóteses de onde } \\
\text { poderiam ter nascido os jogos. A 1ํo hipótese os } \\
\text { paleontólogos encontraram um menino na Gré- } \\
\text { cia } 4 \text { anos antes de Cristo crianças eram enter- } \\
\text { radas com brinquedos, concluíram que os jogos } \\
\text { e as brincadeiras podem ter nascido lá; a } 2^{\circ} \text { é a } \\
\text { da Europa os jogos podem ter surgido lá; } 3^{\circ} \text { um } \\
\text { pesquisador investigando bebês, conclui que o } \\
\text { jogo pode ter surgido da necessidade das crian- } \\
\text { ças para dizer o que querem. }\end{array}$ & $\begin{array}{l}\text { Hipóteses sobre } \\
\text { a origem do jogo. }\end{array}$ \\
\hline 15 (J.P.) & $\begin{array}{l}\text { Identifica hipótese sobre a origem do jogo: Uma } \\
\text { das hipóteses de onde poderiam ter nascido o } \\
\text { jogo é a que os paleontólogos encontraram um } \\
\text { menino na Grécia } 4 \text { anos antes de Cristo enter- } \\
\text { rado com brinquedos, concluíram que os jogos e } \\
\text { as brincadeiras podem ter nascido lá. }\end{array}$ & $\begin{array}{l}\text { Hipóteses sobre } \\
\text { a origem do jogo. }\end{array}$ \\
\hline
\end{tabular}




\begin{tabular}{|c|c|c|}
\hline 17 (L.) & $\begin{array}{l}\text { Identifica algumas hipóteses sobre a origem do } \\
\text { jogo: } 1^{\circ} \text { hipótese os paleontólogos encontraram } \\
\text { um criança grega } 4 \text { anos antes de Cristo que } \\
\text { eram enterradas com brinquedos, concluíram } \\
\text { que os jogos e as brincadeiras podem ter nas- } \\
\text { cido lá; a outra hipótese é que os europeus já } \\
\text { apresentavam jogos desde muito tempo. }\end{array}$ & $\begin{array}{l}\text { Hipóteses sobre } \\
\text { a origem do jogo. }\end{array}$ \\
\hline 18 (L.) & $\begin{array}{l}\text { Identifica hipótese sobre a origem do jogo: Os } \\
\text { jogos podem ter surgido na Europa ou na Gré- } \\
\text { cia. }\end{array}$ & $\begin{array}{l}\text { Hipóteses sobre } \\
\text { a origem do jogo. }\end{array}$ \\
\hline 19 (L.) & $\begin{array}{l}\text { Identifica hipótese sobre a origem do jogo: Fa- } \\
\text { lamos de jogos e vimos que os jogos podem ter } \\
\text { surgido na Europa ou na Grécia. }\end{array}$ & $\begin{array}{l}\text { Hipóteses sobre } \\
\text { a origem do jogo. }\end{array}$ \\
\hline 20 (M.) & $\begin{array}{l}\text { Foi uma aula teórica a professora nos mostrou } 3 \\
\text { exemplos de onde surgiram os jogos. A } 1^{\circ} \text { foi } \\
\text { que surgiram há muito tempo na Grécia, } 2^{\circ} \text { foi } \\
\text { que surgiram na Europa, a } 3^{\circ} \text { foi que surgiram } \\
\text { da necessidade das próprias crianças. }\end{array}$ & $\begin{array}{l}\text { Hipóteses sobre } \\
\text { a origem do jogo. }\end{array}$ \\
\hline $\begin{array}{l}21 \\
\text { (N.M.) }\end{array}$ & $\begin{array}{l}\text { Expõe que a aula tratou sobre algumas hipóte- } \\
\text { ses sobre a origem do jogo. }\end{array}$ & \\
\hline 22 (N.C.) & $\begin{array}{l}\text { Identifica algumas hipóteses sobre a origem do } \\
\text { jogo: Os jogos podem ter nascido na Europa, na } \\
\text { Grécia ou na própria necessidade das crianças. }\end{array}$ & $\begin{array}{l}\text { Hipóteses sobre } \\
\text { a origem do jogo. }\end{array}$ \\
\hline $23(\mathrm{~N})$. & $\begin{array}{l}\text { Identifica hipótese sobre a origem do jogo: Os } \\
\text { jogos podem ter surgido na Europa, na Grécia. }\end{array}$ & $\begin{array}{l}\text { Hipóteses sobre } \\
\text { a origem do jogo. }\end{array}$ \\
\hline
\end{tabular}

Síntese de conteúdos trabalhados na aula, retirados das notas de campo da professora

Aula 5:

Jogos de perseguição:

1) pega-pega cocorô

2) mãe da rua (floresta)

3) barra-manteiga

Conhecer como se pratica cada um dos jogos. 
As habilidades: correr e se desviar com velocidade.

Regras: participar dos jogos se empenhando ao máximo, respeitando as regras dos jogos e não atrapalhando os amigos.

TABELA 27 - Primeira pergunta norteadora - Aula 5

\begin{tabular}{|c|c|c|}
\hline Alunos & $\begin{array}{l}\text { Observações da pro- } \\
\text { fessora sobre os regis- } \\
\text { tros dos alunos }\end{array}$ & $\begin{array}{l}\text { Conteúdos da } \\
\text { identificados nos } \\
\text { gistros dos alunos }\end{array}$ \\
\hline 1 (A.B.) & $\begin{array}{l}\text { Identifica o nome dos } \\
\text { jogos que executou: } \\
\text { 1) pega-pega cocorô; } \\
\text { 2) floresta; } \\
\text { 3) barra-manteiga. }\end{array}$ & $\begin{array}{l}\text { Jogos de perseguição: } \\
\text { 1) pega-pega cocorô; } \\
\text { 2) mãe da rua (floresta); } \\
\text { 3) barra-manteiga. }\end{array}$ \\
\hline 2 (B.) & $\begin{array}{l}\text { Identifica o nome dos } \\
\text { jogos que jogou: } \\
\text { 1) pega-pega cocorô; } \\
\text { 2) floresta; } \\
\text { 3)barra-manteiga, } \\
\text { aplicados na aula. }\end{array}$ & $\begin{array}{l}\text { Jogos de perseguição: } \\
\text { 1) pega-pega cocorô; } \\
\text { 2) mãe da rua (floresta); } \\
\text { 3) barra-manteiga. }\end{array}$ \\
\hline 3 (C.) & $\begin{array}{l}\text { Identifica o nome dos } \\
\text { jogos que jogou: } \\
\text { 1) pega-pega cocorô; } \\
\text { 2) floresta; } \\
\text { 3) barra-manteiga, } \\
\text { aplicados na aula. } \\
\text { Expõe como se cada um } \\
\text { dos jogos. O pega-pega } \\
\text { cocorô era assim, o pe- } \\
\text { gador tinha o direito de } \\
\text { te pegar mas você tinha } \\
\text { o direito de abaixar nisso } \\
\text { o pegador não podia te } \\
\text { pegar. No floresta todos }\end{array}$ & $\begin{array}{l}\text { Jogos de perseguição: } \\
\text { 1) pega-pega cocorô; } \\
\text { 2) mãe da rua (floresta); } \\
\text { 3) barra-manteiga. } \\
\text { Conhecer como se rea- } \\
\text { liza cada um dos jogos. }\end{array}$ \\
\hline
\end{tabular}




\begin{tabular}{|c|c|c|}
\hline & $\begin{array}{l}\text { tinham que ficar parados } \\
\text { e quando o pegador gri- } \\
\text { tava "já" tinha que correr. } \\
\text { No barra-manteiga todos } \\
\text { tinham que estar com a } \\
\text { mão estendida um dos } \\
\text { adversários ia bater na } \\
\text { sua mão se batesse por } \\
\text { último você tinha que ir } \\
\text { atrás dele. } \\
\text { Explica o jogo através } \\
\text { de uma história em qua- } \\
\text { drinhos. }\end{array}$ & \\
\hline $4(\mathrm{~F})$. & $\begin{array}{l}\text { Identifica o nome dos } \\
\text { jogos: } \\
\text { 1) pega-pega cocorô; } \\
\text { 2) mãe da rua; } \\
\text { 3)barra-manteiga, } \\
\text { aplicados na aula. } \\
\text { Expõe como se joga } \\
\text { cada um dos jogos: fo- } \\
\text { mos para a quadra e a } \\
\text { professora dividiu ela } \\
\text { em } 4 \text { partes uma para } \\
\text { jogar pega-pega cocorô } \\
\text { quando o pegador ten- } \\
\text { tasse pegar você podia } \\
\text { se salvar agachando. No } \\
\text { barra-manteiga era for- } \\
\text { mar dois grupos e um } \\
\text { batia na mão do outro e } \\
\text { tinha que sair correndo } \\
\text { para não ser pego, o }\end{array}$ & $\begin{array}{l}\text { Jogos de perseguição: } \\
\text { 1) pega-pega cocorô; } \\
\text { 2) mãe da rua (floresta); } \\
\text { 3) barra-manteiga. } \\
\text { Conhecer como se joga } \\
\text { cada um dos jogos. } \\
\text { As habilidades: correr e } \\
\text { se desviar com veloci- } \\
\text { dade. }\end{array}$ \\
\hline
\end{tabular}




\begin{tabular}{|c|c|c|}
\hline & $\begin{array}{l}\text { grupo que pegar todos } \\
\text { do outro time vence. As } \\
\text { regras da floresta era } \\
\text { uma pessoa ficava no } \\
\text { meio e gritava "já" e todo } \\
\text { mundo saia correndo e a } \\
\text { pessoa que estava no } \\
\text { meio tinha que pegar. } \\
\text { Identifica habilidades do } \\
\text { jogo: Senti dificuldade } \\
\text { no Pique-bandeira ao se } \\
\text { desviar dos colegas, } \\
\text { precisa de mais veloci- } \\
\text { dade. } \\
\text { Usa o desenho para re- } \\
\text { presentar como se joga } \\
\text { cada jogo. }\end{array}$ & \\
\hline 6 (G.B.) & $\begin{array}{l}\text { Identifica o nome dos } \\
\text { jogos: } \\
\text { 1) pega-pega cocorô; } \\
\text { 2) floresta; } \\
\text { 3)barra-manteiga, } \\
\text { aplicados na aula. } \\
\text { Expõe como se joga } \\
\text { cada um dos jogos: na } \\
\text { floresta não pode sair da } \\
\text { parte verde; no pega- } \\
\text { pega cocorô o pegador } \\
\text { na pode pegar as pes- } \\
\text { soas que estiverem } \\
\text { agachadas e no barra- } \\
\text { manteiga na pode pas- } \\
\text { sar a linha da equipe }\end{array}$ & $\begin{array}{l}\text { Jogos de perseguição: } \\
\text { 1) pega-pega cocorô; } \\
\text { 2) mãe da rua (floresta); } \\
\text { 3) barra-manteiga. } \\
\text { Conhecer como se rea- } \\
\text { liza cada um dos jogos. }\end{array}$ \\
\hline
\end{tabular}




\begin{tabular}{|c|c|c|}
\hline & $\begin{array}{l}\text { adversária. } \\
\text { Desenha a estrutura da } \\
\text { aula em circuito e os } \\
\text { jogos que praticou. }\end{array}$ & \\
\hline 8 (G.) & $\begin{array}{l}\text { Identifica o nome dos } \\
\text { jogos: } \\
\text { 1) pega-pega cocorô; } \\
\text { 2) floresta; } \\
\text { 3)barra-manteiga, } \\
\text { aplicados na aula. }\end{array}$ & $\begin{array}{l}\text { Jogos de perseguição: } \\
\text { 1) pega-pega cocorô; } \\
\text { 2) mãe da rua (floresta); } \\
\text { 3) barra-manteiga. }\end{array}$ \\
\hline 9 (I.) & $\begin{array}{l}\text { Identifica o nome dos } \\
\text { jogos: } \\
\text { 1) pega-pega cocorô; } \\
\text { 2) floresta; } \\
\text { 3)barra-manteiga, } \\
\text { aplicados na aula. }\end{array}$ & $\begin{array}{l}\text { Jogos de perseguição: } \\
\text { 1) pega-pega cocorô; } \\
\text { 2) mãe da rua (floresta); } \\
\text { 3) barra-manteiga. }\end{array}$ \\
\hline 10 (I.C.) & $\begin{array}{l}\text { Identifica o nome dos } \\
\text { jogos: } \\
\text { 1) pega-pega cocorô; } \\
\text { 2) floresta; } \\
\text { 3)barra-manteiga, } \\
\text { aplicados na aula. } \\
\text { Expõe como se realiza } \\
\text { cada um dos jogos: } \\
\text { Pega-pega cocorô um } \\
\text { aluno era pegador e os } \\
\text { outros fugiam dele e se } \\
\text { salvavam abaixando se } \\
\text { fosse pego antes de se } \\
\text { abaixar virava pegador; } \\
\text { floresta um de nós ia } \\
\text { para o meio da quadra e } \\
\text { gritava já os outros ti- }\end{array}$ & $\begin{array}{l}\text { Jogos de perseguição: } \\
\text { 1) pega-pega cocorô; } \\
\text { 2) mãe da rua (floresta); } \\
\text { 3) barra-manteiga. } \\
\text { Conhecer como se rea- } \\
\text { liza cada um dos jogos. } \\
\text { Identifica as habilidades } \\
\text { de correr e se desviar } \\
\text { com velocidade, e a re- } \\
\text { gra combinada em aula. }\end{array}$ \\
\hline
\end{tabular}




\begin{tabular}{|c|c|c|}
\hline & $\begin{array}{l}\text { nham que correr para o } \\
\text { outro lado da quadra } \\
\text { sem ser pego; barra- } \\
\text { manteiga o grupo era } \\
\text { separado em dois tipos } \\
\text { um de nós ia no outro } \\
\text { lado e batia na mão do } \\
\text { amigo, amigo tinha que } \\
\text { correr atrás de mim, se } \\
\text { eu passasse a linha do } \\
\text { outro lado eu ganhava } \\
\text { se me pegasse tinha } \\
\text { que era ponto para o } \\
\text { outro time. } \\
\text { Identifica as habilidades } \\
\text { de correr e se desviar } \\
\text { com velocidade. Aponta } \\
\text { a regra: importância de } \\
\text { respeitar as regras com- } \\
\text { binadas. Diz: Houve pro- } \\
\text { blemas de respeito às } \\
\text { regras. Eles foram resol- } \\
\text { vidos com a conversa } \\
\text { entre os amigos e com a } \\
\text { ajuda da professora. }\end{array}$ & \\
\hline 11 (I.C.) & $\begin{array}{l}\text { Identifica o nome dos } \\
\text { jogos: } \\
\text { 1) pega-pega cocorô; } \\
\text { 2) floresta; } \\
\text { 3)barra-manteiga, } \\
\text { aplicados na aula. } \\
\text { Expõe como se realiza } \\
\text { cada um dos jogos, por }\end{array}$ & $\begin{array}{l}\text { Jogos de perseguição: } \\
\text { 1) pega-pega cocorô; } \\
\text { 2) mãe da rua (floresta); } \\
\text { 3) barra-manteiga. } \\
\text { Conhecer como se rea- } \\
\text { liza cada um dos jogos. }\end{array}$ \\
\hline
\end{tabular}




\begin{tabular}{|c|c|c|}
\hline & $\begin{array}{l}\text { meio do desenho: aponta } \\
\text { o espaço dos jogos, } \\
\text { mostra como os joga- } \\
\text { dores devem ficar e in- } \\
\text { sere balões com diálo- } \\
\text { gos para deixar mais } \\
\text { claro como realizou os } \\
\text { jogos. }\end{array}$ & \\
\hline 14 (J.B.) & $\begin{array}{l}\text { Identifica o nome dos } \\
\text { jogos: } \\
\text { 1) pega-pega cocorô; } \\
\text { 2) floresta; } \\
\text { 3)barra-manteiga, } \\
\text { aplicados na aula. } \\
\text { Expõe como se realiza } \\
\text { cada um dos jogos: No } \\
\text { pega-pega cocorô o pe- } \\
\text { gador quando chegar } \\
\text { perto dos que tem fugir } \\
\text { tem que agachar para } \\
\text { não ser pego. Floresta } \\
\text { uma pessoa fica no } \\
\text { meio e as outras fica } \\
\text { num canto e quando a } \\
\text { pessoa que estão no } \\
\text { meio fala já os outros } \\
\text { tem que passar sem ser } \\
\text { pegos. Barra-manteiga } \\
\text { tem dois times um vai ao } \\
\text { time adversário e bate } \\
\text { na palma da mão de } \\
\text { uma pessoa que tem } \\
\text { que sair correndo atrás. }\end{array}$ & $\begin{array}{l}\text { Jogos de perseguição: } \\
\text { 1) pega-pega cocorô; } \\
\text { 2) mãe da rua (floresta); } \\
\text { 3) barra-manteiga. } \\
\text { Conhecer como se rea- } \\
\text { liza cada um dos jogos. }\end{array}$ \\
\hline
\end{tabular}




\begin{tabular}{|c|c|c|}
\hline & $\begin{array}{l}\text { Desenha a estrutura da } \\
\text { aula em circuito e os } \\
\text { jogos que praticou. }\end{array}$ & \\
\hline 15 (J.P.) & $\begin{array}{l}\text { Identifica o nome dos } \\
\text { jogos: } \\
\text { 1) pega-pega cocorô; } \\
\text { 2) floresta; } \\
\text { 3)barra-manteiga, } \\
\text { aplicados na aula. }\end{array}$ & $\begin{array}{l}\text { Jogos de perseguição: } \\
\text { 1) pega-pega cocorô; } \\
\text { 2) mãe da rua (floresta); } \\
\text { 3) barra-manteiga. }\end{array}$ \\
\hline $16(\mathrm{~K})$. & $\begin{array}{l}\text { Identifica o nome dos } \\
\text { jogos: } \\
\text { 1) pega-pega cocorô; } \\
\text { 2) floresta; } \\
\text { 3)barra-manteiga, } \\
\text { aplicados na aula. } \\
\text { Expõe como se realiza } \\
\text { cada um dos jogos: } \\
\text { Aprendi que o pega- } \\
\text { pega cocorô quando } \\
\text { alguém vai te pegar } \\
\text { você abaixa para não } \\
\text { ser pego. O mãe da rua } \\
\text { quem era pego ficava no } \\
\text { meio para tentar pegar } \\
\text { os outros que tentava } \\
\text { passar sem ser pego. E } \\
\text { o outro é o barra-man- } \\
\text { teiga que cada um fica } \\
\text { no seu campo e tem que } \\
\text { bater na mão do outro e } \\
\text { correr para ele não te } \\
\text { pegar até chegar no seu } \\
\text { campo. }\end{array}$ & $\begin{array}{l}\text { Jogos de perseguição: } \\
\text { 1) pega-pega cocorô; } \\
\text { 2) mãe da rua; } \\
\text { 3) barra-manteiga. } \\
\text { Conhecer como se rea- } \\
\text { liza cada um dos jogos. }\end{array}$ \\
\hline
\end{tabular}




\begin{tabular}{|c|c|c|}
\hline 17 (L.) & $\begin{array}{l}\text { Identifica o nome dos } \\
\text { jogos: } \\
\text { 1) pega-pega cocorô; } \\
\text { 2) floresta; } \\
\text { 3)barra-manteiga, } \\
\text { aplicados na aula. } \\
\text { Expõe como se realiza } \\
\text { cada um dos jogos: } \\
\text { Barra-manteiga eu en- } \\
\text { tendi que se faz dois } \\
\text { grupos e que as crian- } \\
\text { ças de cada grupo tem } \\
\text { que ser rápida para não } \\
\text { ser pega depois "do } \\
\text { tapa" na mão. Pega- } \\
\text { pega não pode deixar o } \\
\text { pegador tocar antes de } \\
\text { abaixar. Mãe da rua } \\
\text { precisa ter velocidade } \\
\text { para não te pegarem e } \\
\text { para passar pela rua até } \\
\text { chegar ao outro lado. } \\
\text { ldentifica as habilidades } \\
\text { desse jogo: correr e se } \\
\text { desviar. }\end{array}$ & $\begin{array}{l}\text { Jogos de perseguição: } \\
\text { 1) pega-pega cocorô; } \\
\text { 2) mãe da rua (floresta); } \\
\text { 3) barra-manteiga. } \\
\text { Conhecer como se rea- } \\
\text { liza cada um dos jogos. } \\
\text { As habilidades: correr e } \\
\text { se desviar com veloci- } \\
\text { dade. }\end{array}$ \\
\hline 18 (L.) & $\begin{array}{l}\text { Identifica o nome dos } \\
\text { jogos: } \\
\text { 1) pega-pega cocorô; } \\
\text { 2) floresta; } \\
\text { 3)barra-manteiga, } \\
\text { aplicados na aula. }\end{array}$ & $\begin{array}{l}\text { Jogos de perseguição: } \\
\text { 1) pega-pega cocorô; } \\
\text { 2) mãe da rua (floresta); } \\
\text { 3) barra-manteiga. }\end{array}$ \\
\hline 19 (L.) & $\begin{array}{l}\text { Identifica os nomes dos } \\
\text { jogos: }\end{array}$ & $\begin{array}{l}\text { Jogos de perseguição: } \\
\text { 1) pega-pega cocorô }\end{array}$ \\
\hline
\end{tabular}




\begin{tabular}{|c|c|c|}
\hline & $\begin{array}{l}\text { 1) pega-pega cocorô; } \\
\text { 2) floresta; } \\
\text { 3)barra-manteiga, } \\
\text { aplicados na aula. }\end{array}$ & $\begin{array}{l}\text { 2) mãe da rua (floresta) } \\
\text { 3) barra-manteiga }\end{array}$ \\
\hline 20 (M.) & $\begin{array}{l}\text { Identifica o nome dos } \\
\text { jogos: } \\
\text { 1) pega-pega cocorô; } \\
\text { 2) floresta; } \\
\text { 3)barra-manteiga, } \\
\text { aplicados na aula. }\end{array}$ & $\begin{array}{l}\text { Jogos de perseguição: } \\
\text { 1) pega-pega cocorô; } \\
\text { 2) mãe da rua (floresta); } \\
\text { 3) barra-manteiga. }\end{array}$ \\
\hline 22 (N.C.) & $\begin{array}{l}\text { Identifica os nomes dos } \\
\text { jogos: } \\
\text { 1) pega-pega cocorô; } \\
\text { 2) floresta; } \\
\text { 3)barra-manteiga, } \\
\text { aplicados na aula. } \\
\text { Expõe como se jogam } \\
\text { os jogos: No barra- } \\
\text { manteiga um time fica de } \\
\text { um lado da quadra e } \\
\text { canta barra-manteiga... } \\
\text { 1, } 2 \text {, } 3 \text { batendo na mão } \\
\text { do amigo e quando a } \\
\text { música acaba o último } \\
\text { amigo corre atrás para } \\
\text { pegar quem bateu na } \\
\text { sua mão. Quem for pego } \\
\text { vai para o time adversário. } \\
\text { Floresta é assim, igual } \\
\text { ao mãe da rua, uma } \\
\text { criança fica no meio fala } \\
\text { 1, } 2 \text {, } 3 \text { e já, no meio } \\
\text { tenta pegar alguém }\end{array}$ & $\begin{array}{l}\text { Jogos de perseguição: } \\
\text { 1) pega-pega cocorô; } \\
\text { 2) mãe da rua (floresta); } \\
\text { 3) barra-manteiga. } \\
\text { Conhecer como se joga } \\
\text { os jogos. } \\
\text { As habilidades: correr e } \\
\text { se desviar com velo- } \\
\text { cidade. } \\
\text { Regras: participar dos } \\
\text { jogos se empenhando o } \\
\text { máximo; respeitando as } \\
\text { regras dos jogos. }\end{array}$ \\
\hline
\end{tabular}




\begin{tabular}{|l|l|}
\hline quem for pego vira mão \\
dono da floresta. Iden- \\
tifica as habilidades \\
desse jogo: correr e se \\
desviar. \\
Identifica as regras: se \\
empenhar ao máximo e \\
respeitar as regras com- \\
binadas.
\end{tabular} \mid


ANEXO IV Indícios da segunda pergunta norteadora: O portfólio possibilitou aos alunos identificar as dificuldades de aprendizagem e como fazer para melhorá-las?

TABELA 28 - Segunda pergunta norteadora - Aula 3

\begin{tabular}{|l|l|}
\hline 22 & Nós brincamos de futebol, eu era a goleira houve uns probleminhas \\
(N.C.) & $\begin{array}{l}\text { com a defesa por isso a gente não jogou muito, [os amigos não } \\
\text { entendiam que] o goleiro defende o gol e a defesa que ajuda o } \\
\text { goleiro (...). }\end{array}$ \\
\hline
\end{tabular}

TABELA 29 - Segunda pergunta norteadora - Aula 5

\begin{tabular}{|l|l|}
\hline 4 (F.) & $\begin{array}{l}\text { Identifica os jogos: 1) pega-pega cocorô; 2) mãe da rua; 3) barra- } \\
\text { manteiga, aplicados na aula. } \\
\text { Expõe como se joga cada um dos jogos: Fomos para a quadra e a } \\
\text { professora dividiu ela em } 4 \text { partes uma para jogar pega-pega } \\
\text { cocorô quando o pegador tentasse pegar você podia se salvar } \\
\text { agachando. No barra-manteiga era formar dois grupos e um batia } \\
\text { na mão do outro e tinha que sair correndo para não ser pego, o } \\
\text { grupo que pegar todos do outro time vence. As regras do floresta } \\
\text { era uma pessoa ficava no meio e gritava "já" e todo mundo saia } \\
\text { correndo e a pessoa que estava no meio tinha que pegar. } \\
\text { Identifica habilidades do jogo, quando expõe: Senti dificuldade no } \\
\text { [jogo] floresta ao desviar dos colegas preciso de mais velocidade. }\end{array}$ \\
\hline 10 (I.C.) & $\begin{array}{l}\text { Identifica a importância de respeitar as regras combinadas e diz: } \\
\text { Teve problemas de desrespeito às regras. Eles foram resolvidos } \\
\text { com a conversa entre os amigos e com a ajuda da professora (...). }\end{array}$ \\
\hline
\end{tabular}

TABELA 30 - Segunda pergunta norteadora - Aula 6

\begin{tabular}{|l|l|}
\hline 10 (I.C.) & $\begin{array}{l}\text { Expõe: Na hora de pular no aumenta-aumenta eu não conseguia. } \\
\text { Melhorei quando corri rápido, pulei melhor e mais alto. O problema } \\
\text { foi no quebra-canela as pessoas seguravam muito alto o bastão. } \\
\text { Isto foi resolvido a partir do momento que pudemos dizer qual a } \\
\text { melhor altura para cada um. }\end{array}$ \\
\hline
\end{tabular}




\begin{tabular}{|l|l|}
\hline 17 (L.) & $\begin{array}{l}\text { Aponta que sentiu dificuldade no quebra-canela: Tive um problema, } \\
\text { porque eu pedi para abaixar e não abaixavam. } \\
\text { Diz que resolveu conversando como os amigos. }\end{array}$ \\
\hline 22 & $\begin{array}{l}\text { A aluna escreve: Manter a altura que o amigo pediu quando saltava } \\
\text { (N.C.) a dica que ajudou a melhorar o saltar no quebra-canela. }\end{array}$ \\
\hline
\end{tabular}

TABELA 31 - Segunda pergunta norteadora - Aula 7

\begin{tabular}{|l|l|}
\hline 5 (F.) & $\begin{array}{l}\text { Expõe as dicas que aprendeu na aula para volear bem: Prestar } \\
\text { atenção na peteca; jogar na mão do amigo; correr atrás da peteca; } \\
\text { temos que segurar direito a peteca senão a peteca cai. }\end{array}$ \\
\hline 10 (I.C.) & $\begin{array}{l}\text { A dificuldade que sentiu foi: A peteca caía várias vezes, porque nós } \\
\text { não se concentrava e também batemos com a palma da mão mal. } \\
\text { As dicas que aprendeu na aula: Bater a peteca com a palma da } \\
\text { mão e prestar atenção para ver onde ela vai. }\end{array}$ \\
\hline 19 (L.) & $\begin{array}{l}\text { Sentiu dificuldade para volear: A peteca caía porque ia para outra } \\
\text { direção. } \\
\text { Expõe as dicas: Tem que prestar atenção não só na hora de volear } \\
\text { e de receber a peteca. }\end{array}$ \\
\hline
\end{tabular}

TABELA 32 - Segunda pergunta norteadora - Aula 11

\begin{tabular}{|l|l|}
\hline 2 (B.) & $\begin{array}{l}\text { Expõe a dica mais importante que aprendeu na aula: Fugir } \\
\text { correndo com velocidade para não ser pego. }\end{array}$ \\
\hline 5 (F.) & $\begin{array}{l}\text { Descreve como ficou o jogo transformado. } \\
\text { Expõe as dicas: O objetivo era correr e na brincadeira tinham } 2 \\
\text { pegadores, aí ficou muito fácil, então [foram inseridos mais } \\
\text { pegadores] tiveram muitos pegadores e aí todo mundo correu } \\
\text { bastante. }\end{array}$ \\
\hline 7 (G.R.) & $\begin{array}{l}\text { Expõe a dica que usou para jogar e melhorar suas dificuldades: } \\
\text { Para jogar bem tinha que não ficar parado, correr com velocidade } \\
\text { para não ser pego. }\end{array}$ \\
\hline
\end{tabular}




\begin{tabular}{|c|c|}
\hline 8 (G.) & $\begin{array}{l}\text { Expõe a dica: Tinha que correr com velocidade para jogar bem } \\
\text { esse jogo. }\end{array}$ \\
\hline 11 (I.C.) & $\begin{array}{l}\text { Descreve como jogou. } \\
\text { Expõe um problema: Eu vi gente que andava ao invés de correr se } \\
\text { continuar assim não vou ser pega nunca. As dicas que usou para } \\
\text { melhorar as suas dificuldades: Não ficar parado, correr com } \\
\text { velocidade para não ser pego. Desenha a posição que o fugitivo foi } \\
\text { pego num determinado momento do jogo. }\end{array}$ \\
\hline 12 (J.) & $\begin{array}{l}\text { Descreve como ficou o jogo transformado. Expõe as dicas: Não } \\
\text { podia ficar parado, correr pondo bastante velocidade. Também } \\
\text { apontou as diferenças pontuadas na aula quanto a correr e andar. }\end{array}$ \\
\hline 14 (J.B.) & $\begin{array}{l}\text { Descreve como ficou o jogo transformado. } \\
\text { Expõe a dica: Tinha que se esforçar para não ficar parado e correr } \\
\text { bem rápido. }\end{array}$ \\
\hline 15 (J.P.) & $\begin{array}{l}\text { Descreve como ficou o jogo transformado. } \\
\text { Expõe que aprendeu nesta aula: Quando corremos fazemos } \\
\text { pequenos saltitos e por velocidade, por isso é diferente de andar. } \\
\text { Aponta o problema desse jogo: Tinha que ter mais pegador porque } \\
\text { tinha gente que não corria. }\end{array}$ \\
\hline 18 (L.) & $\begin{array}{l}\text { Descreve como ficou o jogo transformado. } \\
\text { Expõe as dicas que usou para melhorar suas dificuldades no jogo: } \\
\text { Correr rápido, também foi colocado mais pegadores no jogo. }\end{array}$ \\
\hline 19 (L.) & $\begin{array}{l}\text { Expõe: Resolvi os problemas conversando com os amigos que não } \\
\text { cumpriam com as regras e também foi colocado mais pegadores no } \\
\text { jogo. }\end{array}$ \\
\hline $\begin{array}{l}21 \\
(\text { N.C. })\end{array}$ & $\begin{array}{l}\text { Descreve como ficou o jogo transformado. } \\
\text { Aponta que o problema de desrespeito às regras, por parte de } \\
\text { alguns colegas, foi resolvido por meio da conversa e a inserção de } \\
\text { mais pegadores no jogo. }\end{array}$ \\
\hline $\begin{array}{l}22 \\
\text { (N.M.) }\end{array}$ & $\begin{array}{l}\text { Descreve como ficou o jogo transformado. } \\
\text { Expõe: Quando algum amigo não respeitava as regras eu tentava } \\
\text { conversar com ele porque isso atrapalhava o jogo }\end{array}$ \\
\hline
\end{tabular}


TABELA 33 - Segunda pergunta norteadora - Aula 12

\begin{tabular}{|c|c|}
\hline 1 (A.B.) & $\begin{array}{l}\text { Expõe: Como tinham poucos pegadores no jogo isso foi resolvido } \\
\text { colocando mais pegadores, e o jogo ficou mais legal. }\end{array}$ \\
\hline 7 (G.R.) & $\begin{array}{l}\text { Explicita os problemas: No início do jogo só havia um pegador, o } \\
\text { jogo melhorou depois que foram colocados quatro pegadores. } \\
\text { Tinha um pegador que entrava no círculo dos alunos pegos. E } \\
\text { completa: Junto a professora conversamos para deixar claro que } \\
\text { isso não valia. }\end{array}$ \\
\hline 10 (I.C.) & $\begin{array}{l}\text { Explicita todas as dicas que foram discutidas na aula: velocidade } \\
\text { para pegar, fugir e salvar os amigos. E expõe: } O \text { jogo melhorou } \\
\text { depois que se colocou mais quatro pegadores. }\end{array}$ \\
\hline $16(\mathrm{~K})$. & $\begin{array}{l}\text { As dicas para jogar bem esse jogo são: Correr bastante, ter reflexo } \\
\text { e fugir do pegador dando olé [se desviando]. } \\
\text { Expõe: Um pegador era pouco para participar mais e correr mais, } \\
\text { quando colocamos mais } 4 \text { pegadores resolvemos o problema deste } \\
\text { jogo. }\end{array}$ \\
\hline 17 (L.) & Uma dica importante: Ter velocidade na hora de salvar o amigo. \\
\hline 18 (L.) & $\begin{array}{l}\text { Explicita dois problemas: Tinha só um pegador e o jogo melhorou } \\
\text { depois que se colocou quatro pegadores; tinha um pegador que } \\
\text { entrava no círculo dos alunos pegos. }\end{array}$ \\
\hline 21 (N.M.) & $\begin{array}{l}\text { Expõe todas as dicas que foram discutidas na aula: velocidade } \\
\text { para pegar, fugir e salvar os amigos. } \\
\text { Cita: Achei importante tentar resolver os problemas com os amigos } \\
\text { usando a conversa sem ajuda da professora. }\end{array}$ \\
\hline
\end{tabular}

TABELA 34 - Segunda pergunta norteadora - Aula 13

\begin{tabular}{|l|l|}
\hline 10 (I.C.) & $\begin{array}{l}\text { Cita que nessa aula foi falado como se devem fazer os registros } \\
\text { diários e que jogaram pique-bandeira. } \\
\text { Problema identificado: Tinham pessoas que não aceitavam que } \\
\text { eram pegas. A gente conversou e entrou num acordo com o grupo } \\
\text { após pedirem tempo no jogo para resolver este problema }\end{array}$ \\
\hline
\end{tabular}


TABELA 35 - Segunda pergunta norteadora - Aula 14

\begin{tabular}{|l|l|}
\hline 1 (A.B.) & $\begin{array}{l}\text { Cita os problemas: Tinha uma menina que queria pegar a bola, ela } \\
\text { passava por onde não podia. Nós nos reunimos, conversamos e foi } \\
\text { tudo bem. }\end{array}$ \\
\hline 8 (G.) & $\begin{array}{l}\text { Cita: Essa aula mostrou que seguir regras é a melhor coisa para o } \\
\text { jogo dar certo e não ter problemas. }\end{array}$ \\
\hline 10 (I.C.) & $\begin{array}{l}\text { Expõe o que aprendeu: Os problemas devem ser resolvidos na } \\
\text { hora e sem ficar chamando a professora. }\end{array}$ \\
\hline
\end{tabular}

TABELA 36 - Segunda pergunta norteadora - Aula 18

\begin{tabular}{|l|l|}
\hline 4 (F.) & $\begin{array}{l}\text { Explica como jogou, utilizando-se da escrita. } \\
\text { As dificuldades encontradas foram: saltar a cela numa altura maior. } \\
\text { Expõe que aprendeu uma dica para melhorar o saltar: Pegar mais } \\
\text { impulso com a corrida e prestar atenção na altura e na distância } \\
\text { que preciso saltar. }\end{array}$ \\
\hline 5 (F.) & $\begin{array}{l}\text { Escreve e desenha como jogou. O que é interessante em seu } \\
\text { desenho são as divisões de espaço e a prática do jogo realizado } \\
\text { em duplas. } \\
\text { Expõe: Às vezes, quando eu saltava pisava nos bastões e } \\
\text { escorregava. Eu resolvi este problema, só quando diminuí a } \\
\text { distância entre os bastões quando ia saltar. }\end{array}$ \\
\hline 7 (G.R.) & $\begin{array}{l}\text { Explica como se pratica o jogo proposto, utilizando-se da escrita. } \\
\text { Diz: Tive dificuldade no pula-sela por causa dos bastões que havia } \\
\text { entre a sela. Expõe: Melhorei nesta parte do jogo quando pude } \\
\text { saltar de outras maneiras. }\end{array}$ \\
\hline 9 (I.) & $\begin{array}{l}\text { Um problema: } \text { A minha amiga deixava a altura da cela muito baixa. } \\
\text { A solução foi mostrar qual era a altura melhor para mim toda vez } \\
\text { que ia saltar. Outra dificuldade: Fazer o salto afastado na cela. } \\
\text { Melhorou quando a professora deixou a gente criar outras formas } \\
\text { de saltar. }\end{array}$ \\
\hline 11 (I.C.) & $\begin{array}{l}\text { Expõe a dica: Pegar distância para correr e saltar com mais } \\
\text { impulso. } \\
\text { Expõe a dica: A gente precisa correr para pegar impulso, jogar o }\end{array}$ \\
\hline 12 (J.)
\end{tabular}




\begin{tabular}{|l|l|}
\hline & $\begin{array}{l}\text { corpo para frente e apoiar as mãos nas costas do amigo quando } \\
\text { fazia o salto sob a sela. }\end{array}$ \\
\hline 14 (J.B.) & $\begin{array}{l}\text { Expõe a dica mais importante que aprendeu no jogo: Dar impulso } \\
\text { para saltar melhor; escolher a altura da cela que quer saltar; tomar } \\
\text { distância, correr bem rápido e saltar. }\end{array}$ \\
\hline 16 (K.) & Ressalta que foi importante se concentrar para executar esse salto. \\
(N.C.) & $\begin{array}{l}\text { Expõe o que aprendeu: Correr para dar impulso e saltar melhor; } \\
\text { tentar se superar aumentando cada vez mais alto para saltar e que } \\
\text { tem várias formas de saltar. }\end{array}$ \\
\hline
\end{tabular}

TABELA 37 - Segunda pergunta norteadora - Aula 19

\begin{tabular}{|l|l|}
\hline 1 (A.B.) & $\begin{array}{l}\text { Expõe que sentiu dificuldades após pisar na corda e acabou } \\
\text { caindo. Resolveu seu problema de medo de cair tentando } \\
\text { novamente e não desistindo de fazer. }\end{array}$ \\
\hline 2 (B.) & $\begin{array}{l}\text { Expõe a dica: Quando saltar deve jogar o corpo para cima o } \\
\text { máximo que puder. }\end{array}$ \\
\hline 5 (F.) & $\begin{array}{l}\text { Expõe que nessa aula as dicas eram: Escolher a melhor altura que } \\
\text { conseguia saltar; não importar se o amigo ia mais rápido que o } \\
\text { outro o importante era conseguir saltar o melhor que podia. }\end{array}$ \\
\hline 9 (I.) & $\begin{array}{l}\text { Expõe o problema dessa aula: Pessoas que desistiam nas } \\
\text { primeiras tentativas. A solução: Entender que é preciso perder o } \\
\text { medo e não desistir. }\end{array}$ \\
\hline 10 (I.C.) & $\begin{array}{l}\text { Expõe um problema: Uma menina enroscou o pé na corda e não } \\
\text { queria mais participar. Diz que isso foi resolvido por meio da } \\
\text { conversa entre a professora e o grupo: Concluímos que se não } \\
\text { tentarmos jamais conseguiremos superar novos desafios. }\end{array}$ \\
\hline
\end{tabular}

TABELA 38 - Segunda pergunta norteadora - Aula 20

\begin{tabular}{|l|l|}
\hline 2 (B.) & $\begin{array}{l}\text { Cita que venceu as dificuldades para saltar tentando executar as } \\
\text { seguintes dicas: Pegar velocidade e quando saltar fazer o mais alto } \\
\text { possível para não bater nos obstáculos; manter o equilíbrio quando } \\
\text { terminar os saltos. }\end{array}$ \\
\hline 5 (F.) & Expõe: Entendi que para ter mais impulso era só correr bem rápido \\
\hline
\end{tabular}




\begin{tabular}{|l|l|}
\hline 6 (G.B.) & e que é importante amortecer a queda após executar um salto. \\
\hline 9 (I.) & $\begin{array}{l}\text { Cita a dica mais importante que aprendeu nessa aula: saltar na } \\
\text { altura que conseguia e superar os desafios sem desistir. }\end{array}$ \\
\hline 12 (J.) & $\begin{array}{l}\text { Cita que nos jogos a dica mais importante era pegar velocidade } \\
\text { para ter mais impulso e respeitar as regras para que os jogos } \\
\text { dessem certo. }\end{array}$ \\
\hline $\begin{array}{l}\text { 22 } \\
\text { (N.C.) }\end{array}$ & $\begin{array}{l}\text { Cita as dicas mais importantes: Pegar impulso, jogando o corpo } \\
\text { para cima ou para frente. }\end{array}$ \\
\hline
\end{tabular}

TABELA 39 - Segunda pergunta norteadora - Aula 21

\begin{tabular}{|c|c|}
\hline 2 (B.) & $\begin{array}{l}\text { Expõe o que aprendeu: Manter a atenção na bexiga para voleá-la; } \\
\text { resolver os problemas sozinho; anotar na agenda o registro para } \\
\text { não se esquecer de fazê-lo. }\end{array}$ \\
\hline 6 (G.B.) & $\begin{array}{l}\text { Expõe que a dica mais importante dessa atividade era volear com } \\
\text { força a bexiga para cima. }\end{array}$ \\
\hline $9(\mathrm{I})$. & $\begin{array}{l}\text { Expõe por meio do desenho que a dica é bater na bexiga, } \\
\text { empurrando-a para cima. }\end{array}$ \\
\hline 11 (I.C.) & $\begin{array}{l}\text { Expõe a dica: Saltar se fosse preciso para conseguir volear a } \\
\text { bexiga; correr atrás da bexiga; prestar atenção. }\end{array}$ \\
\hline 14 (J.B.) & $\begin{array}{l}\text { Expõe, por meio do desenho, a dica: manter a atenção na bexiga } \\
\text { para voleá-la batendo-a com a palma da mão. }\end{array}$ \\
\hline 15 (J.P.) & $\begin{array}{l}\text { Expõe as dicas: Colocar a mão debaixo da bexiga e empurrar com } \\
\text { a palma das mãos para volear bem; na atividade individual é } \\
\text { necessário pensar que estamos jogando com nós mesmos. }\end{array}$ \\
\hline 18 (L.) & $\begin{array}{l}\text { Expõe a dica: Não ficar parado para volear, é necessário se } \\
\text { deslocar até a bexiga. } \\
\text { Problema: Não conseguia volear para o colega por causa do vento. } \\
\text { Isso foi resolvido mudando o jogo em dupla para outro em que } \\
\text { tinham que jogar sozinhos com a bexiga. }\end{array}$ \\
\hline 19 (L.) & $\begin{array}{l}\text { Expõe a dica: Colocar a mão debaixo da bexiga e empurrar com a } \\
\text { palma das mãos para volear bem. }\end{array}$ \\
\hline $23(\mathrm{~N})$. & iz: Senti dificuldades para receber a bexiga e volear por causa do \\
\hline
\end{tabular}




\begin{tabular}{|l|l|}
\hline $\begin{array}{l}\text { vento, mas isso foi resolvido mudando o jogo em dupla para outro } \\
\text { que a gente jogou sozinho. }\end{array}$ \\
\hline
\end{tabular}

TABELA 40 - Segunda pergunta norteadora - Aula 22

\begin{tabular}{|l|l|}
\hline 5 (F.) & $\begin{array}{l}\text { Diz: Senti dificuldades para receber a bexiga e volear por causa do } \\
\text { vento, mas isso foi resolvido mudando o jogo em dupla para outro } \\
\text { que a gente jogou sozinho. }\end{array}$ \\
\hline 11 (I.C.) & $\begin{array}{l}\text { Desenha e escreve identificando as regras e o objetivo dos jogos } \\
\text { propostos. } \\
\text { Diz: } \text { A dificuldade para volear foi diminuída tentando por em prática } \\
\text { as seguintes dicas: se o voleio é sozinho deve deixar a mão perto } \\
\text { para bater novamente no objeto; se o voleio for feito em dupla é } \\
\text { necessário ir até o objeto e volear mirando no colega. }\end{array}$ \\
\hline 13 (J.) & $\begin{array}{l}\text { Desenha apresentando as dicas: olhar para o objeto, ficar de frente } \\
\text { para o amigo que vai volear ou que irá receber o voleio, pôr a mão } \\
\text { embaixo do balão e volear na direção do amigo. }\end{array}$ \\
\hline 16 (K.) & $\begin{array}{l}\text { Escreve, apresentando as dicas: Tem que fazer de tudo para não } \\
\text { deixar a bola, peteca ou bexiga cair, a gente tem que ver onde vai o } \\
\text { objeto quando for receber. }\end{array}$ \\
\hline 17 (L.) & $\begin{array}{l}\text { Escreve, apresentando a dica: Se o voleio é com dupla agente tem } \\
\text { que ir até o objeto e volear mirando no colega, se esforçar para o } \\
\text { cansaço não deixar a gente parar de jogar. }\end{array}$ \\
\hline 19 (L.) & $\begin{array}{l}\text { Escreve, ressaltando que relembramos os objetivos já atingidos e } \\
\text { aqueles que falta serem alcançados, que os jogos foram } \\
\text { construídos de forma coletiva e identifica as regras e como se } \\
\text { realiza cada um dos jogos propostos. } \\
\text { Diza direcionaro o voleio com a bola de borracha e não ficar parado. } \\
\text { propostos, inserindo o recurso de setas para explicitar como jogou } \\
\text { em cada estação. }\end{array}$ \\
\hline 10
\end{tabular}




\begin{tabular}{|l|l|}
\hline & $\begin{array}{l}\text { Desenha, representando as dicas: a bexiga deve ser voleada } \\
\text { batendo a palma da mão, volear sempre de frente para o amigo, } \\
\text { ver aonde a bola vai. }\end{array}$ \\
\hline
\end{tabular}

TABELA 41 - Segunda pergunta norteadora - Aula 23

\begin{tabular}{|c|c|}
\hline 1 (A.B.) & $\begin{array}{l}\text { Expõe as dicas para melhorar o voleio: A bexiga deve ser voleada } \\
\text { batendo a palma da mão, volear sempre de frente para o amigo, } \\
\text { ver aonde a bola vai. }\end{array}$ \\
\hline 2 (B.) & $\begin{array}{l}\text { Expõe as dicas para melhorar o voleio: A bexiga deve ser voleada } \\
\text { batendo a palma da mão, volear sempre de frente para o amigo. } \\
\text { Diz que os amigos não respeitavam as regras, o que foi resolvido } \\
\text { após conversa da professora com o grupo. }\end{array}$ \\
\hline $3(\mathrm{C})$. & $\begin{array}{l}\text { Expõe as dicas para melhorar o voleio: } A \text { bexiga deve ser voleada } \\
\text { batendo a palma da mão, volear sempre de frente para o amigo. }\end{array}$ \\
\hline $4(\mathrm{~F})$. & $\begin{array}{l}\text { Expõe as dicas para melhorar o voleio: A bexiga deve ser voleada } \\
\text { batendo a palma da mão, volear sempre de frente para o amigo, } \\
\text { ver aonde a bola, peteca ou bexiga vai. }\end{array}$ \\
\hline $5(\mathrm{~F})$. & $\begin{array}{l}\text { Expõe as dicas para melhorar o voleio: A bexiga deve ser voleada } \\
\text { usando a palma da mão, volear sempre de frente para o amigo. } \\
\text { Aponta que alguns amigos não respeitavam as regras, e expõe: } \\
\text { Tentamos conversar com a ajuda da professora do grupo com } \\
\text { estes alunos. }\end{array}$ \\
\hline 6 (G.B.) & $\begin{array}{l}\text { Expõe a dica para melhorar o voleio: Volear sempre de frente para } \\
\text { o amigo. }\end{array}$ \\
\hline 10 (I.C.) & $\begin{array}{l}\text { Expõe as dicas para melhorar o voleio: Volear a bexiga com a } \\
\text { palma da mão, ficar de frente para o amigo. }\end{array}$ \\
\hline 11 (I.C.) & $\begin{array}{l}\text { Dicas para melhorar o voleio: Volear batendo a palma da mão, ficar } \\
\text { de frente para o amigo. } \\
\text { Alguns alunos que não respeitava as regras e melhoramos depois } \\
\text { de conversar com a professora e o grupo. }\end{array}$ \\
\hline $12(\mathrm{~J})$. & $\begin{array}{l}\text { Dica para melhorar o voleio: } A \text { bexiga tem que ser voleada batendo } \\
\text { a palma da mão. }\end{array}$ \\
\hline $13(\mathrm{~J})$. & cas para melhorar o voleio: Volear batendo com a palma da mão \\
\hline
\end{tabular}




\begin{tabular}{|l|l|}
\hline & $\begin{array}{l}\text { e ficar sempre de frente para o amigo. } \\
\text { Havia amigos que não respeitavam as regras, o que foi resolvido } \\
\text { após conversa da professora com o grupo. }\end{array}$ \\
\hline 14 (J.B.) & $\begin{array}{l}\text { Expõe a dica para melhorar o voleio: Volear batendo com a palma } \\
\text { da mão na bexiga. }\end{array}$ \\
\hline 15 (J.P.) & Expõe a dica para melhorar o voleio: usar a palma da mão. \\
\hline 16 (K.) & $\begin{array}{l}\text { Expõe a dica para melhorar o voleio: ficar sempre de frente para o } \\
\text { amigo. }\end{array}$ \\
\hline 20 (M.) & $\begin{array}{l}\text { Expõe a dica para melhorar o voleio: volear batendo com a palma } \\
\text { da mão. }\end{array}$ \\
\hline 21 & Expõe a dica para melhorar o voleio: volear com a palma da mão. \\
(N.M.) & $\begin{array}{l}\text { Para melhorar o voleio: volear batendo a palma da mão e ficar de } \\
\text { frente para o amigo. }\end{array}$ \\
\hline 22 \\
(N.C.)
\end{tabular}


ANEXO V Indícios da terceira pergunta norteadora: A auto-avaliação como mais um instrumento inserido no portfólio dos alunos possibilitou a aprendizagem dos aspectos relacionados à postura de estudante?

TABELA 42 - Aula 8 - Primeira auto-avaliação - Questões 1 e 2

\begin{tabular}{|c|c|c|}
\hline Alunos & $\begin{array}{l}\text { 1. Qual atividade realizada lhe } \\
\text { possibilitou aprender novos } \\
\text { conhecimentos? }\end{array}$ & $\begin{array}{l}\text { 2. Em qual proposta você teve } \\
\text { mais dificuldade e por quê? }\end{array}$ \\
\hline 1 (A.B.) & $\begin{array}{l}\text { Barra mantega. Porque foi com } \\
\text { ele que eu aprendi muitas coizas. }\end{array}$ & $\begin{array}{l}\text { Pique bandera. Porque eu não } \\
\text { sabia oque fazer. }\end{array}$ \\
\hline 2 (B.) & $\begin{array}{l}\text { Sobre as hipoteses da onde veio } \\
\text { os jogos se foi da Grécia de } \\
\text { Portugal ou da Espanha. }\end{array}$ & $\begin{array}{l}\text { A da peteca para que você tem } \\
\text { que } \\
\text { ter mais reflexo, mais } \\
\text { velocidade. }\end{array}$ \\
\hline 3 (C.) & $\begin{array}{l}\text { Um dia meu irmão me ensinou a } \\
\text { jogar peteca e na aula de } \\
\text { educação fízica agente fez o jogo } \\
\text { de peteca na aula joguei mas o } \\
\text { meu par é horrível. }\end{array}$ & $\begin{array}{l}\text { Até agora nenhuma mas não } \\
\text { quer dizer que foi facil. }\end{array}$ \\
\hline $4(\mathrm{~F})$. & $\begin{array}{l}\text { Aprendi o que é jogos, conhecer } \\
\text { jogos da cultura motora, aprender } \\
\text { a jogar para atigir os objetivos, } \\
\text { resolver problemas e etc. }\end{array}$ & $\begin{array}{l}\text { A fazer pesquiza com meus } \\
\text { pais, porque não tinha tempo } \\
\text { para fazer a pesquiza. }\end{array}$ \\
\hline $5(F)$. & $\begin{array}{l}\text { Eu aprendi no dia que o objetivo } \\
\text { era saltar e eu tinha conseguido } \\
\text { saltar em uma distância que eu } \\
\text { nunca tinha conseguido. }\end{array}$ & $\begin{array}{l}\text { No dia que teve pique bandeira } \\
\text { que só tinha eu na defeza e não } \\
\text { dava para defender. }\end{array}$ \\
\hline 6 (G.B.) & $\begin{array}{l}\text { O pique bandeira porque eu não } \\
\text { sabia de augumas coisas e agora } \\
\text { eu sei. }\end{array}$ & $\begin{array}{l}\text { No pique bandeira porque eu } \\
\text { ainda não conhecia algumas } \\
\text { regras desse jogo. }\end{array}$ \\
\hline 7 (G.R.) & $\begin{array}{l}\text { Durante todas essas aulas eu a- } \\
\text { prendi mais sobre a educação físi- }\end{array}$ & $\begin{array}{l}\text { Eu teve mais dificudade poi em } \\
\text { cuase em todas aulas porque eu }\end{array}$ \\
\hline
\end{tabular}




\begin{tabular}{|c|c|c|}
\hline & ca e conheci outros jogos. & $\begin{array}{l}\text { não fazia } e \text { só } \\
\text { comentários. }\end{array}$ \\
\hline 8 (G.) & $\begin{array}{l}\text { O dia que descobrimos o que é } \\
\text { jogo porque isso resumia tudo o } \\
\text { que nos iamos aprender. }\end{array}$ & $\begin{array}{l}\text { A minha maior dificuldade foi } \\
\text { nos registros e ate alguns jogos } \\
\text { porque eu não treinava em casa. }\end{array}$ \\
\hline 9 (I.) & $\begin{array}{l}\text { A brincadeira é aumenta-aumenta. } \\
\text { Porque vai aumentando. }\end{array}$ & $\begin{array}{l}\text { Quando agente joga pula-sela } \\
\text { por que todo mum não } \\
\text { agansava direito. }\end{array}$ \\
\hline 10 (I.C.) & $\begin{array}{l}\text { Quase todos os jogos que a } \\
\text { professora passou na quadra em } \\
\text { aula. Porque os meus amigos me } \\
\text { ajudou muuito em todos os jogos } \\
\text { e também me apoiaaram quando } \\
\text { eu fazia o grupo perde. }\end{array}$ & $\begin{array}{l}\text { Eu senti dificuldade na aula que } \\
\text { nos aprendemos pique- } \\
\text { bandeira, Porque eu tinha } \\
\text { esquecido e eu não sabia que } \\
\text { quando nós pegamos a bola nós } \\
\text { não pode jogar para o amigo. }\end{array}$ \\
\hline 11 (I.C.) & $\begin{array}{l}\text { Um dia a profa nos levou para o } \\
\text { auditório e nos falou de onde pode } \\
\text { ter surgido os jogos infantis. } \\
\text { E ela falou que podia ter sido na } \\
\text { Europa, e eu nem imaginava isso } \\
\text { antes. }\end{array}$ & $\begin{array}{l}\text { No quebra quanela tinha horas } \\
\text { que eu fiqueiva com dificuldade } \\
\text { para pular. }\end{array}$ \\
\hline 12 (J.) & $\begin{array}{l}\text { Aprendi outros jogos em casa e } \\
\text { quadra e aprendi a resolver os } \\
\text { problemas dos jogos e ensinar as } \\
\text { crianças outros jogos. }\end{array}$ & $\begin{array}{l}\text { Não fazer os registros de Ed. } \\
\text { Fisica. }\end{array}$ \\
\hline $13(\mathrm{~J})$. & $\begin{array}{l}\text { Aprendi novas regras e vários } \\
\text { jogos. }\end{array}$ & $\begin{array}{l}\text { Eu tive dificuldade quando foi a } \\
\text { brincadeira quebra canela. }\end{array}$ \\
\hline 14 (J.B.) & $\begin{array}{l}\text { Foi a aula que a professora } \\
\text { mostrou } 3 \text { exemplos onde podem } \\
\text { ter nacido os jogos. Eu aprendi } \\
\text { muito porque a professora nos } \\
\text { deu muito conhecimento. }\end{array}$ & $\begin{array}{l}\text { Eu tive na aula da peteca eu tive } \\
\text { dificuldade em rebater a peteca } \\
\text { para o meu amigo. }\end{array}$ \\
\hline 15 (J.P.) & $\begin{array}{l}\text { No dia que foi aula de pique- } \\
\text { pandeira eu não sabia de }\end{array}$ & $\begin{array}{l}\text { Foi quando a profesora } \\
\text { escreveu umonte de coisa na }\end{array}$ \\
\hline
\end{tabular}




\begin{tabular}{|c|c|c|}
\hline & $\begin{array}{l}\text { aulgumas regras agora eu jogo } \\
\text { direidinho. }\end{array}$ & 10 \\
\hline $16(\mathrm{~K})$. & Eu aprender mais na peteca. & Foi na picbandeira \\
\hline 17 (L.) & $\begin{array}{l}\text { Fazendo os registros. Porque en- } \\
\text { quanto eu ia fazendo os registros } \\
\text { eu fui fazendo eu fui percebendo } \\
\text { que eu estava melhorando porque } \\
\text { os registros vem da nossa sabe- } \\
\text { doria. }\end{array}$ & $\begin{array}{l}\text { Eu tive mais dificuldades nas ati- } \\
\text { vidades aumenta-aumenta, pula- } \\
\text { sela e quebra-canela porque eu } \\
\text { sou muito acostumada e sou } \\
\text { muito pequena e as vezes me } \\
\text { atrapalhava mais vou me } \\
\text { esforçar para melhorar. }\end{array}$ \\
\hline 18 (L.) & $\begin{array}{l}\text { Eu aprendi mais no dia que nós } \\
\text { fomos para o auditório, porque a } \\
\text { professora mostrou algumas hipó- } \\
\text { teses de uma autora que fala sobre } \\
\text { o que é jogo. }\end{array}$ & $\begin{array}{l}\text { Eu tive dificuldade no jogo da } \\
\text { peteca, pois não sabia jogar, } \\
\text { então depois dessa aula e } \\
\text { comecei a jogar peteca em } \\
\text { casa. }\end{array}$ \\
\hline 19 (L.) & $\begin{array}{l}\text { A atividade foi a peteca oque me } \\
\text { ajudou foi a minha vontade. Porque } \\
\text { eu adoro peteca. }\end{array}$ & $\begin{array}{l}\text { Foi quando nós gogamos pega } \\
\text { bandeira. Porque eu não tive } \\
\text { muita "amizade" com esse jogo. }\end{array}$ \\
\hline 20 (M.) & $\begin{array}{l}\text { O registro, porque antes eu não } \\
\text { sabia o que era portifolio mas a } \\
\text { professora me explicou. }\end{array}$ & $\begin{array}{l}\text { Eu tive mais dificuldade em } \\
\text { naquele dia que tivemos que } \\
\text { pular a distância os aumenta- } \\
\text { aumenta. }\end{array}$ \\
\hline 21 (N.M.) & $\begin{array}{l}\text { Foi no dia da entrega da pesquisa, } \\
\text { porque eu reaprendi alguns jogos, } \\
\text { e joguei jogos que eu já sabia mas } \\
\text { com diferentes nomes. }\end{array}$ & $\begin{array}{l}\text { Foi no dia que jogamos petécas, } \\
\text { porque não conseguia rebater, } \\
\text { ou seja, senti muita dificuldade } \\
\text { em rebater a petéca. }\end{array}$ \\
\hline 22 (N.C.) & $\begin{array}{l}\text { A peteca porque eu aprendi a } \\
\text { mirar a rebater. E teve uma } \\
\text { pesquisa que os pais falaram que } \\
\text { eles jogavão quando eram } \\
\text { pequenos. }\end{array}$ & $\begin{array}{l}\text { Teve au gus alunos que } \\
\text { demostraram onde os jogos } \\
\text { surgiram eu não entendi a } \\
\text { esplicasão por que era muita cois. } \\
\text { E deve uma aula que teve } 4 \text { jogos } \\
\text { poriso eu aprendi menos leve } \\
\text { agun proplema. }\end{array}$ \\
\hline
\end{tabular}




\begin{tabular}{|l|l|l|l|}
23 (N.) & $\begin{array}{l}\text { Das hipóteses de onde vieram os } \\
\text { jogos eu escolhi as hipóteses por alerta que os pais jogavam } \\
\text { que eu não sabia tem hipóteses. }\end{array}$ & $\begin{array}{l}\text { quando eram crianças a a } \\
\text { dificuldade que eu senti foi } \\
\text { passar a bola para o amigo do } \\
\text { lado. }\end{array}$ \\
\hline
\end{tabular}

TABELA 43 - Aula 8 - Primeira auto-avaliação - Questões 3 e 4

\begin{tabular}{|c|c|c|}
\hline Alunos & $\begin{array}{l}\text { 3. Comente a participação da } \\
\text { turma na sua aprendizagem e } \\
\text { sua participação na } \\
\text { aprendizagem de seus colegas. }\end{array}$ & $\begin{array}{l}\text { 4. O que você deixou de } \\
\text { fazer? Por quê? }\end{array}$ \\
\hline 1 (A.B.) & $\begin{array}{l}\text { De que tudo que eu passei o que } \\
\text { foi mais difício foi queimada que o } \\
\text { meu amigo meu ajudou a passar } \\
\text { do outro lado. Eu ajudei a minha } \\
\text { amiga a passar para o outro lado } \\
\text { sem ninguém pegar ela. }\end{array}$ & $\begin{array}{l}\text { O registro. Mais foi que não da } \\
\text { tempo mais agora esta bem } \\
\text { melhor. }\end{array}$ \\
\hline 2 (B.) & $\begin{array}{l}\text { Eu aprendi quase tudo a até } \\
\text { jogos precisa velocidade. }\end{array}$ & Os registros e outras coisas. \\
\hline 3 (C.) & $\begin{array}{l}\text { Já ajudaram falando o que teve } \\
\text { na aula para o registro. }\end{array}$ & $\begin{array}{l}\text { Eu só deixo de fazer quando } \\
\text { estou doente. }\end{array}$ \\
\hline $4(\mathrm{~F})$. & $\begin{array}{l}\text { Aprendi com os colegas opiniões } \\
\text { de jogos a participação e eu } \\
\text { aprendi com meus colegas } \\
\text { completando as opiniões. }\end{array}$ & Eu não tive de fazer nenhum. \\
\hline $5(\mathrm{~F})$. & $\begin{array}{l}\text { A minha colega me ajudou na } \\
\text { defesa e a } 9 \text { (I.) também me } \\
\text { ajudou e eu ajudei a } 14 \text { (J.) a } \\
\text { lançar a bola. }\end{array}$ & Nada. \\
\hline 6 (G.B.) & $\begin{array}{l}\text { Eles me isplicaram as regras dos } \\
\text { jogos para eles e eles também } \\
\text { me einsinaram as regras dos } \\
\text { jogos que eu não conhecia. }\end{array}$ & $\begin{array}{l}\text { Pesquisas porque eu achei } \\
\text { que eu não precisava. }\end{array}$ \\
\hline
\end{tabular}




\begin{tabular}{|c|c|c|}
\hline 7 (G.R.) & $\begin{array}{l}\text { Teve um dia que nós jogamos } \\
\text { peteca e tinha algumas } \\
\text { estratégias e habilidades como } \\
\text { rebater, segurar a peteca na } \\
\text { parte vermelha e bater na palma } \\
\text { da mão. }\end{array}$ & $\begin{array}{l}\text { Eu deixei de fazer algumas } \\
\text { lições porque eu esquecia. }\end{array}$ \\
\hline 8 (G.) & $\begin{array}{l}\text { Algumas veses eu fasia errado e } \\
\text { eles me avisarão e algumas veses } \\
\text { eu tambem falei ajudei muitos } \\
\text { amigos e muitos amigas. }\end{array}$ & Eu não deixei de fazer nada. \\
\hline 9 (I.) & $\begin{array}{l}\text { Quando eu estava com de } \\
\text { dificudade quando eu joguei } \\
\text { peteca uma amiga me ajudou e } \\
\text { eu levei uma pesquisa e ajudei a } \\
\text { turma. }\end{array}$ & $\begin{array}{l}\text { Alguns registros não tive } \\
\text { tempo. }\end{array}$ \\
\hline 10 (I.C.) & $\begin{array}{l}\text { Eles me ajudou na aula do pique- } \\
\text { bandeira falando como se jogava } \\
\text { e me explicou que nós não } \\
\text { podemos jogar a bola para o } \\
\text { amigo. Eu ajudei na aula de } \\
\text { queimada e quando as meninas } \\
\text { tinha deixando a bola cair no } \\
\text { chão. }\end{array}$ & Eu nuca dexei de fazer nada. \\
\hline 11- (I.C.) & $\begin{array}{l}\text { Participação dos colegas: um dia } \\
\text { a prof. dividiu a classe em } 4 \\
\text { partes e tabém } 4 \text { brincadeiras e } \\
\text { toda hora trocava de brincadeira. } \\
\text { Teve uma hora que o meu time } \\
\text { teve que jogar barra manteiga e } \\
\text { eu não sabia jogar, eles me } \\
\text { explicaram direitinho a } \\
\text { brincadeira. Minha participação: } \\
\text { um dia a prof. estava explicando }\end{array}$ & $\begin{array}{l}\text { Uma atividade que era para } \\
\text { fazer em casa, mas eu tive } \\
\text { que ajudar a minha mãe com a } \\
\text { mudança. }\end{array}$ \\
\hline
\end{tabular}




\begin{tabular}{|c|c|c|}
\hline & $\begin{array}{l}\text { hipóteses de como pode ter } \\
\text { surgido os jogos infantis, ela falou } \\
\text { que poderia ter vindo da: Europa } \\
\text { e Grécia. Eu tenho um livro sobre } \\
\text { o Egito que tinha uma parte que } \\
\text { falava de brinquedos egípcios } \\
\text { antigos, e ninguém imaginava que } \\
\text { também pode ter vindo do Egito } \\
\text { Antiqo!!! }\end{array}$ & \\
\hline $13(\mathrm{~J})$. & $\begin{array}{l}\text { Quando eu não sabia jogar } \\
\text { peteca. }\end{array}$ & $\begin{array}{l}\text { Quando eu não trouxe } 0 \\
\text { registro. }\end{array}$ \\
\hline 14 (J.B.) & $\begin{array}{l}\text { Nas conversas de final de aula } \\
\text { eles falam muitas coisas e eu } \\
\text { aprendo muito. }\end{array}$ & $\begin{array}{l}\text { Eu não deixei de fazer nenhum } \\
\text { registro. }\end{array}$ \\
\hline 15 (J.P.) & $\begin{array}{l}\text { Ninguém nunca me ajudou, mas } \\
\text { uma vez no futebol eu ajudei } \\
\text { porque falei para uma amiga ir } \\
\text { para um lado. }\end{array}$ & $\begin{array}{l}\text { Eu nunca deixei de fazer oso } \\
\text { registros. }\end{array}$ \\
\hline $16(\mathrm{~K})$. & Foi o grupo do 4 (F.) e do 2 (B.). & $\begin{array}{l}\text { Eu não fiz picbandeira e eu } \\
\text { esqueci de fazer os registros. }\end{array}$ \\
\hline 17 (L.) & $\begin{array}{l}\text { Eles me ajudaram conversando e } \\
\text { dando dica e eu dando dica e } \\
\text { ajudando os amigos. }\end{array}$ & $\begin{array}{l}\text { O registro porque ás vezes eu } \\
\text { esqueço. }\end{array}$ \\
\hline 18 (L.) & $\begin{array}{l}\text { O dia que os meu amigos me } \\
\text { ajudaram foi o dia que teve barra } \\
\text { manteiga. } \\
\text { Eu ajudei os colegas no dia que } \\
\text { teve o futebol. }\end{array}$ & $\begin{array}{l}\text { Não deixei de fazer nada porque } \\
\text { eu participei de todas } \\
\text { atividades. }\end{array}$ \\
\hline 19 (L.) & $\begin{array}{l}\text { Eu ensinei a mimha colega a } \\
\text { jogar peteca e ela me ajudou } \\
\text { falando para eu me concentrar na } \\
\text { peteca. }\end{array}$ & Eu não deixei de fazer nada. \\
\hline
\end{tabular}




\begin{tabular}{|l|l|l|}
\hline 20 (M.) & $\begin{array}{l}\text { No dia que nós demos exemplos } \\
\text { sobre o que é jogo. }\end{array}$ & $\begin{array}{l}\text { As vezes eu isquecia de fazer } \\
\text { o e ficava devendo. }\end{array}$ \\
\hline 21 (N.M.) & $\begin{array}{l}\text { Foi no dia que jogamos } \\
\text { queimada, porque me ajudaram e faltei no dia que a } \\
\text { eu ajudei algumas pessoas. }\end{array}$ & $\begin{array}{l}\text { Eu } \\
\text { professora falou sobre o ortifolio e deixei de fazer } \\
\text { alguns registros. }\end{array}$ \\
\hline 22 (N.C.) & $\begin{array}{l}\text { Eu falei para um amigo correr } \\
\text { mais. } \\
\text { Um amigo falou pra mim jogar na } \\
\text { direção dele. }\end{array}$ & $\begin{array}{l}\text { No comeso do ano eu cai e } \\
\text { tive que ficar sentada no } \\
\text { banco com gelo. }\end{array}$ \\
\hline 23 (N.) & $\begin{array}{l}\text { jogo que meus amigos me } \\
\text { ajudaram foi da floresta que vive } \\
\text { ou mãe da rua eles falaram que } \\
\text { tinha esperar o pegador falasse } \\
\text { já. }\end{array}$ & $\begin{array}{l}\text { Eu não pesquizei nada por que achava nada em } \\
\text { textos, internet. }\end{array}$ \\
\hline
\end{tabular}

TABELA 44 - Aula 8 - Primeira auto-avaliação - Questões 5 e 6

\begin{tabular}{|l|l|l|}
\hline Alunos & $\begin{array}{l}5 . \quad \text { Você pesquisou outros } \\
\text { materiais para complementar o } \\
\text { seu portfólio? }\end{array}$ & $\begin{array}{l}\text { 6. Em que aspectos você ainda } \\
\text { precisa melhorar? }\end{array}$ \\
\hline 1 (A.B.) & Eu não pesquisa nada. & $\begin{array}{l}\text { Eu presiso pesquisar mais e } \\
\text { praticar mais jogo. }\end{array}$ \\
\hline 2 (B.) & Eu não pesquisa nada. & Em meu reflexo. \\
\hline $3($ C.) & $\begin{array}{l}\text { Eu não fiz isso eu só registrei } \\
\text { da aula. }\end{array}$ & $\begin{array}{l}\text { Quando tem algum pega pega } \\
\text { que tinha que falar alguma } \\
\text { coisa no grupo para fazer um } \\
\text { planinho para ganhar. }\end{array}$ \\
\hline 4 (F.) & $\begin{array}{l}\text { Eu não pesquisei mas aprendi } \\
\text { com ela [as pesquisas dos } \\
\text { colegas] conhecer jogos da } \\
\text { cultura motora a ensinar as } \\
\text { crianças, aprender atingir os } \\
\text { objetivos dos jogos, e aprender }\end{array}$ & $\begin{array}{l}\text { Lembrar de fazer os registros, } \\
\text { volear melhor e um pouco } \\
\text { resolver os problemas. }\end{array}$ \\
\hline
\end{tabular}




\begin{tabular}{|c|c|c|}
\hline & a resolver problemas. & \\
\hline $5(\mathrm{~F})$. & $\begin{array}{l}\text { Eu já achei uma pesquisa } \\
\text { sobre os jogos e eu vou ler e } \\
\text { vou trazer. }\end{array}$ & Em lançar a bola. \\
\hline 6 (G.B.) & $\begin{array}{l}\text { Sim sobre os materiais que eu } \\
\text { usei na aula. }\end{array}$ & Correr, pular, saltar, etc. \\
\hline 7 (G.R.) & $\begin{array}{l}\text { Eu usei desenho e aprendi } \\
\text { muita coisa. }\end{array}$ & $\begin{array}{l}\text { Eu preciso melhorar nas lições } \\
\text { de Educação Física. }\end{array}$ \\
\hline 8 (G.) & Não. & $\begin{array}{l}\text { Na cordenação motora e em } \\
\text { outras coisas. }\end{array}$ \\
\hline 9 (I.) & Não. & Jogar. \\
\hline 10 (I.C.) & $\begin{array}{l}\text { Eu coloquei até agora três } \\
\text { coisas que é uma pesquisa de } \\
\text { onde surgiu os jogos, colei } \\
\text { uma peteca de papel e } \\
\text { procurei no dicionário o } \\
\text { significado de peteca. Eu } \\
\text { aprendi que os registros são } \\
\text { mais bonitos com alguma coisa } \\
\text { diferente. }\end{array}$ & $\begin{array}{l}\text { Eu preciso melhorar as minhas } \\
\text { habilidades motoras. }\end{array}$ \\
\hline 11 (I.C.) & $\begin{array}{l}\text { Eu vou dar um jeito de tirar } \\
\text { xerox de } 2 \text { livros que eu tenho, } \\
\text { só ainda não tirei xerox por } \\
\text { que não consegui. }\end{array}$ & $\begin{array}{l}\text { Eu acho que eu preciso } \\
\text { participar mais da brincadeira, e } \\
\text { prestar mais atenção. }\end{array}$ \\
\hline $12(\mathrm{~J})$. & Não. & No portifólio. \\
\hline $13(\mathrm{~J})$. & Ter mas força & Rebater. \\
\hline 14 (J.B.) & Nenhuma pesquiza. & Eu acho que nada. \\
\hline 15 (J.P.) & Eu nunca fiz pesquiza. & \\
\hline $16(\mathrm{~K})$. & Eu deixei de pesquisar. & $\begin{array}{l}\text { Na peteca tem vezes que eu } \\
\text { chuto. }\end{array}$ \\
\hline 17 (L.) & Não. & $\begin{array}{l}\text { Na mira em alguns jogos e } \\
\text { lembrar dos registros. }\end{array}$ \\
\hline 18 (L.) & Eu pesquisei sobre o pique- & Lançar e rebater. \\
\hline
\end{tabular}




\begin{tabular}{|l|l|l|}
\hline & $\begin{array}{l}\text { bandeira. Eu fiquei sabendo } \\
\text { que esses jogos de pegar vem } \\
\text { do pega-pega. }\end{array}$ & $\begin{array}{l}\text { Eu preciso melhorar no jogo } \\
\text { pega bandeira e usar materiais } \\
\text { para fazer o diário de educação } \\
\text { física. }\end{array}$ \\
\hline 19 (L.) & $\begin{array}{l}\text { Eu não uzei material. } \\
\text { Nas aulas teóricas porque } \\
\text { quase não falo. }\end{array}$ \\
\hline 21 (N.M.) & $\begin{array}{l}\text { Eu pesquisei o pique bandeira } \\
\text { de } 4 \text { bolas. }\end{array}$ & $\begin{array}{l}\text { Em alguns registros eu preciso } \\
\text { melhorar e em alguns jogos. }\end{array}$ \\
\hline 22 (N.C.) & Jogos novos e regras novas. & $\begin{array}{l}\text { Eu acho que quando a gente } \\
\text { fala no final da aula sobre a a } \\
\text { aula eu preciso falar mais. }\end{array}$ \\
\hline 23 (N.) & Eu não pesquizei nada. & $\begin{array}{l}\text { Nos registros e lembrar de por o } \\
\text { nome, série. }\end{array}$ \\
\hline
\end{tabular}

TABELA 45 - Aula 25 - Segunda auto-avaliação - Questões 1 e 2

\begin{tabular}{|c|c|c|}
\hline Alunos & $\begin{array}{l}\text { 1. Qual atividade realizada the } \\
\text { possibilitou aprender novos } \\
\text { conhecimentos? }\end{array}$ & $\begin{array}{l}\text { 2. Em qual proposta você teve mais } \\
\text { dificuldade e por quê? }\end{array}$ \\
\hline 1 (A.B.) & $\begin{array}{l}\text { O registro (...) porque ele me fez } \\
\text { aprender mais coisas dos jogos. }\end{array}$ & $\begin{array}{l}\text { Na proposta do Registro. Porque } \\
\text { não registrava. }\end{array}$ \\
\hline 2 (B.) & $\begin{array}{l}\text { A do pega pega mão para } \\
\text { frenteque nós eventamos porque } \\
\text { não aprendi a envitariar. }\end{array}$ & $\begin{array}{l}\text { Da peteca porquê tem que ter mais } \\
\text { velo-cidade. }\end{array}$ \\
\hline 3 (C.) & $\begin{array}{l}\text { Aprender a correr na roda que nós } \\
\text { faziamos antes ou depois da aula, eu } \\
\text { não lembro. } \\
\text { Eu corria muito pouco mas depois } \\
\text { que o G.B. falou que se corresse } \\
\text { nas pontas dos pés e mexendo os } \\
\text { braços...demais. }\end{array}$ & $\begin{array}{l}\text { Olha prô, eu falei que tive } \\
\text { dificuldades nos registros mais são } \\
\text { tão pequenas que nem dá pra ex- } \\
\text { plicar porque. }\end{array}$ \\
\hline
\end{tabular}




\begin{tabular}{|c|c|c|}
\hline 4 (F.) & $\begin{array}{l}\text { Na quadra, porque nós corremos, } \\
\text { pulamos e voleamos e também } \\
\text { pensei que rebater e volear era a } \\
\text { mesma coisa mas aprendi que não } \\
\text { é. }\end{array}$ & $\begin{array}{l}\text { A dificuldade mais difício para mim } \\
\text { foi volear a peteca porque era muito } \\
\text { difício volear rápido com a coisa } \\
\text { pequena. }\end{array}$ \\
\hline $5(\mathrm{~F})$. & $\begin{array}{l}\text { No dia que nós brincamos de } \\
\text { peteca porque a Professora disse } \\
\text { que se chama voleio. }\end{array}$ & $\begin{array}{l}\text { No dia que nós bincamos de Pique } \\
\text { Bandeira de bolar porque o } 13 \text { (J.) } \\
\text { pegava as } 3 \text { bolas de uma vez só. }\end{array}$ \\
\hline \multicolumn{3}{|l|}{6 (G.B.) } \\
\hline 7 (G.R.) & $\begin{array}{l}\text { Na quadra porque a prô em } \\
\text { algumas discuções ela ensinava } \\
\text { coisas novas. }\end{array}$ & $\begin{array}{l}\text { Na proposta de criar um jogo em } \\
\text { grupo. }\end{array}$ \\
\hline 8 (G.) & $\begin{array}{l}\text { Na quadra por que alguns tinham } 4 \\
\text { estacões. }\end{array}$ & $\begin{array}{l}\text { Em atividade com peteca por que } \\
\text { não sei voleiar direito }\end{array}$ \\
\hline $9(\mathrm{I})$. & $\begin{array}{l}\text { Aumenta-Aumenta porque eu não } \\
\text { sabia que esse jogo não essistia e } \\
\text { me envolvel as saltar mas a } \\
\text { distancia. }\end{array}$ & $\begin{array}{l}\text { Voleio eu no conseguia volear mito } \\
\text { bem o balão, peteca e o volei. }\end{array}$ \\
\hline 10 (I.C.) & $\begin{array}{l}\text { A última aula que eu tive que } \\
\text { refalar das dicas e do resto das } \\
\text { coisas, me ajudou a lembrar de } \\
\text { tudo que aprendemos. }\end{array}$ & $\begin{array}{l}\text { Na hora de jogar peteca, eu acho } \\
\text { chato e difícil }\end{array}$ \\
\hline 11 (I.C.) & $\begin{array}{l}\text { Foi na atividade como aprender a } \\
\text { volear, Porque nós aprendemos } \\
\text { que quando nós batemos em um } \\
\text { objeto sem nenhum objeto na mão, } \\
\text { ex.: raquete isso chama voleio, não } \\
\text { rebater. }\end{array}$ & $\begin{array}{l}\text { Eu ainda estou com dificuldade de } \\
\text { como saltar em altura e distancia. }\end{array}$ \\
\hline $12(\mathrm{~J})$. & $\begin{array}{c}\text { Na atividade que nos } \\
\text { transformamos jogos de saltar. }\end{array}$ & Nas atividades de volear. \\
\hline $13(\mathrm{~J})$. & $\begin{array}{c}\text { Aprendi em todas, porque todas me } \\
\text { vez conheser. }\end{array}$ & Nem uma. \\
\hline
\end{tabular}




\begin{tabular}{|c|c|c|}
\hline 14 (J.B.) & Nenhuma, pois todos eu conheço & $\begin{array}{l}\text { Foi no pic bandeira, eu não sabia, } \\
\text { mais depois eu fui aprendendo e } \\
\text { até que eu consegui fazer tudo. }\end{array}$ \\
\hline \multicolumn{3}{|l|}{15 (J.P.) } \\
\hline \multicolumn{3}{|l|}{$16(\mathrm{~K})}$. \\
\hline 17 (L.) & $\begin{array}{l}\text { Peteca, por que consegui me } \\
\text { equilibrar. }\end{array}$ & $\begin{array}{l}\text { Nos jogos de } 4 \text { etapas. Porque não } \\
\text { comseguia saltar. }\end{array}$ \\
\hline 18 (L.) & $\begin{array}{l}\text { Na peteca, porque eu tive } \\
\text { dificuldade para cumprir, o jogo. }\end{array}$ & $\begin{array}{l}\text { Eu não tive dificuldade com nada } \\
\text { porque eu entendi as orientações } \\
\text { do profa. }\end{array}$ \\
\hline 19 (L.) & $\begin{array}{l}\text { Um dia eu no meu apartamento } \\
\text { deci brincar com minha amiga e eu } \\
\text { percebi que aprendi a correr mais. } \\
\text { Porque eu e minha amiga } \\
\text { estavamos brincando de correr e } \\
\text { eu aprendi a ser mais veloz. } \\
\text { Também com as dicas da prô!!!, } \\
\text { mas tem que querer. }\end{array}$ & $\begin{array}{l}\text { Foi um dia que a nossa classe } \\
\text { jogava pega bandeira e eu sinto } \\
\text { dificuldade porque eu não entendia } \\
\text { as regras mas então conversei com } \\
\text { o grupo e eu entendi. }\end{array}$ \\
\hline 20 (M.) & $\begin{array}{c}\text { As aulas práticas, nela aprendo } \\
\text { novos jogos. }\end{array}$ & Os registros, eu esquecia as dicas. \\
\hline 21 (N.M.) & $\begin{array}{l}\text { Foi o jogo Salta Salta, Salta que o } \\
\text { grupo da } 11 \text { (l.C.) transformou e } \\
\text { gostei porque aprendi a correr mais } \\
\text { e a saltar mais. }\end{array}$ & $\begin{array}{l}\text { Tive dificuldades nos jogos das } \\
\text { etações, em bater e rebater a } \\
\text { peteca. }\end{array}$ \\
\hline 22 (N.C.) & $\begin{array}{l}\text { Foi na sala eu fiz um cartaz para a } \\
\text { pro eu pensava que volear usava } \\
\text { instrumentos e ela me explicou que } \\
\text { volear é sem instrumento só com } \\
\text { as mãos. }\end{array}$ & $\begin{array}{l}\text { Para saltar porque eu não } \\
\text { consequia impulsionar o corpo ou } \\
\text { não sabia a distânsia era pra pular. }\end{array}$ \\
\hline $23(\mathrm{~N})$. & $\begin{array}{l}\text { Porque eu pude aprender novos } \\
\text { jogos, novas regras e saber o que } \\
\text { melhorar. }\end{array}$ & \\
\hline
\end{tabular}


TABELA 46 - Aula 25 - Segunda auto-avaliação - Questões 3 e 4

\begin{tabular}{|c|c|c|}
\hline Alunos & $\begin{array}{l}\text { 3. Comente a participação da } \\
\text { turma na sua aprendizagem e } \\
\text { sua participação na } \\
\text { aprendizagem de seus colegas. }\end{array}$ & $\begin{array}{l}\text { 4. O que você deixou de fazer? } \\
\text { Por quê? }\end{array}$ \\
\hline 1 (A.B.) & $\begin{array}{l}\text { Quando era a ves de eu falar } \\
\text { eles } \\
\text { não escutaram mas alguns } \\
\text { escutavam. }\end{array}$ & $\begin{array}{l}\text { Eu deixei de fazer pesquisas } \\
\text { registros a minha irma não } \\
\text { deixava. }\end{array}$ \\
\hline $2(\mathrm{~B})$ & Está muito bem. & $\begin{array}{l}\text { Os registros porque não tenho } \\
\text { muito tempo. }\end{array}$ \\
\hline $3(\mathrm{C})$. & $\begin{array}{l}\text { Um dia eu ajudei uma parceira a } \\
\text { correr mais, e ela mesmo me } \\
\text { lembrou de uma coisa um dia } \\
\text { que não podia fazer. }\end{array}$ & $\begin{array}{l}\text { Ás vezes quando a professora } \\
\text { falou que no pega-pega não } \\
\text { podia parar de correr mas eu } \\
\text { cansei muito... }\end{array}$ \\
\hline $4(\mathrm{~F})$. & $\begin{array}{l}\text { Acho que os colegas e eu } \\
\text { aprendemos a respeitar o amigo } \\
\text { e resolver os problemas sem } \\
\text { chamar a professora, resolver } \\
\text { conversando. }\end{array}$ & $\begin{array}{l}\text { Registros e pesquisas. } \\
\text { Pesquisas porque não achei, os } \\
\text { registros não dá tempo, faço só } \\
\text { às vezes. }\end{array}$ \\
\hline $5(\mathrm{~F})$. & $\begin{array}{l}\text { O meu colega me ensinou a } \\
\text { correr para trás e eu ensinei a } \\
\text { minha colega a rebater a bola. }\end{array}$ & \\
\hline \multicolumn{3}{|l|}{6 (G.B.) } \\
\hline 7 (G.R) & $\begin{array}{l}\text { Os meus amigos as vezes } \\
\text { brigavam por exemplo: Um dia a } \\
\text { prô disse que era aula livre e aí } \\
\text { jogamos futebol e teve muita } \\
\text { briga. }\end{array}$ & $\begin{array}{l}\text { Eu deixei de fazer os regitros } \\
\text { porque eu esquecia. }\end{array}$ \\
\hline 8 (G.) & $\begin{array}{l}\text { Em alguinhas veses eles me } \\
\text { falavam o que era para fazer e } \\
\text { eu tambem fazia isto. }\end{array}$ & $\begin{array}{l}\text { Muitos registros por que eu não } \\
\text { lembrava. }\end{array}$ \\
\hline
\end{tabular}




\begin{tabular}{|c|c|c|}
\hline 9 (I.) & $\begin{array}{l}\text { Quando eu levei uma pesquisa } \\
\text { de onde surgiu o jogos. Quando } \\
\text { a minha amiga levou uma } \\
\text { pesquisa. }\end{array}$ & $\begin{array}{l}\text { Os registos porque eu tinha } \\
\text { viajado. }\end{array}$ \\
\hline 10 (I.C.) & & $\begin{array}{l}\text { Já deixei de fazer vário } \\
\text { registros por que não deu } \\
\text { tempo. }\end{array}$ \\
\hline 11 (I.C.) & $\begin{array}{l}\text { No dia do jogo pula-sela com } \\
\text { banco, eu ajudei um amigo a } \\
\text { pular melhor o banco eu falei } \\
\text { para ele mudar o seu jeito de } \\
\text { pular e isso deu certo e ele } \\
\text { conseguiu pular o banco. No dia } \\
\text { que nós jogamos o aumenta- } \\
\text { aumenta com corda elástica, a } \\
\text { professora me deu uma díca } \\
\text { correr mais rapido, iria ajudar eu } \\
\text { melhorar o meu salto. }\end{array}$ & Nada \\
\hline $12(\mathrm{~J})$. & Nenhuma. & Pesquisar. \\
\hline $13(\mathrm{~J})$. & $\begin{array}{l}\text { Alguns conversavam mas eu } \\
\text { tambem converso muito e isso } \\
\text { atrapalha. }\end{array}$ & $\begin{array}{l}\text { De vez enquando eu esquecia } \\
\text { de fazer o registro e de vez } \\
\text { enquando não dava tempo. }\end{array}$ \\
\hline 14 (J.B.) & $\begin{array}{l}\text { Todos da equipe é muito legal e } \\
\text { todos procuram ajudar todos. }\end{array}$ & $\begin{array}{l}\text { Variar coisas no registro, às } \\
\text { vezes eu esquecia de fazer } \\
\text { porque eu viajava. }\end{array}$ \\
\hline \multicolumn{3}{|l|}{15 (J.P.) } \\
\hline \multicolumn{3}{|l|}{$16(\mathrm{~K})}$. \\
\hline 17 (L.) & $\begin{array}{l}\text { A minha aprendisagem com os } \\
\text { meus colegas foi ótima eles me } \\
\text { ajudaram e eu ajudei eles. }\end{array}$ & Registro porque esquecía. \\
\hline 18 (L.) & $\begin{array}{l}\text { Me ajudaram na atividade de } \\
\text { voleada. Ajudei o grupo na }\end{array}$ & $\begin{array}{l}\text { Não deixei de fazer nada, } \\
\text { cumpri todas os tarefas dadas }\end{array}$ \\
\hline
\end{tabular}




\begin{tabular}{|c|c|c|}
\hline & atividade da peteca. & pela prof \\
\hline 19 (L.) & $\begin{array}{l}\text { Um dia a minha amiga não } \\
\text { conseguia entender o jogo e eu } \\
\text { expliquei e ela entendeu. }\end{array}$ & $\begin{array}{l}\text { Eu deixei de fazer pesquisas, } \\
\text { poque não tinha tempo, mas } \\
\text { agora me organizei. }\end{array}$ \\
\hline 20 (M.) & $\begin{array}{l}\text { Nos jogos nós ajudavamos para } \\
\text { vencer. }\end{array}$ & As vezes os registros. \\
\hline 21 (N.M.) & & $\begin{array}{l}\text { Registro porque esquecia e não } \\
\text { dava tempo. }\end{array}$ \\
\hline 22 (N.C.) & $\begin{array}{l}\text { O grupo estava unido mas eu } \\
\text { não lembro de ter ajudado } \\
\text { alguém nem niguém ter me } \\
\text { ajudado. }\end{array}$ & $\begin{array}{l}\text { Uma vez la perto do começo do } \\
\text { ano não fiz o registro. }\end{array}$ \\
\hline 23 (N.) & & $\begin{array}{l}\text { Eu deixei de fazer os registros } \\
\text { porque eu esquecia. }\end{array}$ \\
\hline
\end{tabular}

TABELA 47 - Aula 25 - Segunda auto-avaliação - Questões 5 e 6

\begin{tabular}{|l|l|l|}
\hline Alunos & $\begin{array}{l}\text { 5. Você pesquisou outros materiais } \\
\text { para complementar seu portfólio? }\end{array}$ & $\begin{array}{l}\text { 6. Em que aspectos você } \\
\text { ainda precisa melhorar? }\end{array}$ \\
\hline 1 (A.B.) & $\begin{array}{l}\text { Eu não levava pesquisa e não utilizei } \\
\text { esse material e ulilizei o meu } \\
\text { conhecimento. }\end{array}$ & $\begin{array}{l}\text { Eu preciso ainda melhorar a } \\
\text { resolver os problemas que } \\
\text { fico chamando a professora } \\
\text { toda a hora. }\end{array}$ \\
\hline 2 (B.) & $\begin{array}{l}\text { Muito. } \\
\text { Na reflexo. }\end{array}$ \\
\hline 4 (C.) & $\begin{array}{l}\text { Eu fiz uma cartolina explicando } \\
\text { melhor, eu aprendi as flexibilidades } \\
\text { desses jogos. }\end{array}$ & $\begin{array}{l}\text { Acho que pular em um pé } \\
\text { só. }\end{array}$ \\
\hline 5 (F.) & Não. & $\begin{array}{l}\text { Lempuisei esses materiais. de fazero os } \\
\text { resgistros, volear melhor e } \\
\text { um poco a resolver os } \\
\text { problemas. }\end{array}$ \\
\hline
\end{tabular}




\begin{tabular}{|c|c|c|}
\hline 6 (G.B.) & Não fez. & Não fez. \\
\hline 7 (G.R.) & Não usei outros materiais. & Na corrida no salto. \\
\hline 8 (G.) & Não. & Voleiar melhor as petecas. \\
\hline 9 (I.) & Não. & No voleio. \\
\hline 10 (I.C.) & $\begin{array}{l}\text { Eu já levei } 2 \text { livros falando sobre } \\
\text { jogos gregos e egípcios, com tudo } \\
\text { isto cheguei a conclusão que der de } \\
\text { que o Mundo é Mundo as crianças }\end{array}$ & Ter + diciplina. \\
\hline 11 (I.C.) & $\begin{array}{l}\text { Sim, eu fiz uma maquete de } \\
\text { massinha, eu aprendi que você pode } \\
\text { fazer o registro de outra forma sem } \\
\text { ser escrevendo. }\end{array}$ & $\begin{array}{l}\text { Eu preciso melhorar o meu } \\
\text { salto. }\end{array}$ \\
\hline $12(\mathrm{~J})$. & Não pesquisei nada. & Na de volear \\
\hline 13 (J.) & $\begin{array}{l}\text { Olha eu pesquisei uma vez, mas eu } \\
\text { aprendi. }\end{array}$ & Na peteca. \\
\hline 14 (J.B.) & Não porque eu não sabia. & Mãe da rua. \\
\hline 15 (J.P.) & Não fez. & Não fez. \\
\hline $16(\mathrm{~K})$. & Não fez. & Não fez. \\
\hline 17 (L.) & Não. & Correr. \\
\hline 18 (L.) & $\begin{array}{l}\text { Sim, completaram as informações } \\
\text { que tive sobre os diferentes jogos e } \\
\text { brincadeiras. }\end{array}$ & Voleada. \\
\hline 19 (L.) & Não. & Saltar. \\
\hline 20 (M.) & Não pesquisei. & Pesquisas e registros. \\
\hline 21 (N.M.) & Não. & $\begin{array}{lll}\text { Correr, } & \text { prestar mais } \\
\text { atenção. } & & \\
\end{array}$ \\
\hline 22 (N.C.) & $\begin{array}{l}\text { Pesquisei uma coisa errada mas } \\
\text { aprendi muita coisa. Aprendi que } \\
\text { volear se joga como a mão. }\end{array}$ & $\begin{array}{l}\text { Pretar mais atenção na } \\
\text { aula. }\end{array}$ \\
\hline
\end{tabular}




\begin{tabular}{|l|l|l|}
\hline $23(\mathrm{~N})$. & $\begin{array}{l}\text { Ouvir o que a professora e } \\
\text { os amigos falam. }\end{array}$ \\
\hline
\end{tabular}


ANEXO VI Indícios da quarta pergunta norteadora: O portfólio possibilitou à professora reflexão sobre a sua prática pedagógica?

4a) Aula 3: Diário da aula

Percebeu-se que permitir fazer registros utilizando diferentes linguagens motivou os alunos a buscarem outras formas de registrar, pois uma das reclamações era o fato de ter que produzir registros escrevendo.

4b) Aula 3: Observações da professora sobre os registros dos alunos

Os jogos escolhidos da pesquisa realizada com os pais motivaram os alunos tanto na aula quanto na produção dos seus registros, pois a maioria fez o registro cumprindo com os critérios preestabelecidos na aula.

4c) Aula 7: Diário da aula

Percebi que a construção do mapa conceitual possibilitou observar o que os alunos haviam aprendido e revelar o que não ficou muito claro.

TABELA 48 - Quarta pergunta norteadora - Observações sobre a primeira coleta do porttólio

\begin{tabular}{|l|l|}
\hline Alunos & Avaliação das aulas realizada pelos alunos \\
\hline 1 (A.B.) & $\begin{array}{l}\text { Elogia: A professora que ensina muitos jogos. } \\
\text { Sugere: Diminuir as brigas. }\end{array}$ \\
\hline 2 (B.) & $\begin{array}{l}\text { Elogia: Os jogos que exigem velocidade, reflexo. } \\
\text { Sugere: Futebol todo dia. }\end{array}$ \\
\hline 3 (C.) & $\begin{array}{l}\text { Elogia: A motivação da professora. } \\
\text { Sugere: Respeito àquele que está falando. }\end{array}$ \\
\hline 4 (F.) & $\begin{array}{l}\text { Elogia: Jogo de correr. } \\
\text { Critica: Aulas teóricas, brigas entre amigos. } \\
\text { Sugere: Menos aulas teóricas. }\end{array}$ \\
\hline 5 (F.) & $\begin{array}{l}\text { Elogia: Quando o jogo dá certo. } \\
\text { Sugere: Mais participação e cooperação. }\end{array}$ \\
\hline 6 (G.B.) & $\begin{array}{l}\text { Elogia: O respeito entre amigos. } \\
\text { Sugere: Fazer um jogo que tivesse um pouco de cada coisa dos jogos } \\
\text { feitos nas últimas aulas. }\end{array}$ \\
\hline
\end{tabular}




\begin{tabular}{|c|c|}
\hline 7 (G.R.) & $\begin{array}{l}\text { Elogia: Os jogos. } \\
\text { Sugere: Regras mais claras, mais tempo para a aula. }\end{array}$ \\
\hline 8 (G.) & $\begin{array}{l}\text { Elogia: as aulas de educação Física. } \\
\text { Sugere: que os alunos possam escolher os jogos e diversificar os } \\
\text { materiais. }\end{array}$ \\
\hline 9 (I.C.) & $\begin{array}{l}\text { Elogia: Discussões na aula. } \\
\text { Critica: A falta de respeito às regras. }\end{array}$ \\
\hline 10 (I.C.) & $\begin{array}{l}\text { Elogia: Atenção e compreensão da professora. } \\
\text { Sugere: Escolher os jogos da aula. }\end{array}$ \\
\hline 11 (I.) & $\begin{array}{l}\text { Elogia: A professora. } \\
\text { Sugere: Mais jogos. } \\
\text { Critica: Amigos que não tinham cuidado com os colegas no pula-sela. }\end{array}$ \\
\hline 12 (J.) & $\begin{array}{l}\text { Elogia: Jogos de correr. } \\
\text { Sugere: Mais jogos de correr e saltar. }\end{array}$ \\
\hline 13 (J.) & $\begin{array}{l}\text { Elogia: Jogos de correr e com bola. } \\
\text { Sugere: Diminuição das brigas, e que todos cumpram com as tarefas } \\
\text { de casa. }\end{array}$ \\
\hline 14 (J.B.) & $\begin{array}{l}\text { Elogia: Jogos. } \\
\text { Sugere: Mais respeito às regras. } \\
\text { Critica: Brigas. }\end{array}$ \\
\hline 15 (J.P.) & $\begin{array}{l}\text { Elogia: Respeito às regras. } \\
\text { Sugere: Ter mais cooperação. } \\
\text { Critica: Brigas. }\end{array}$ \\
\hline $16(\mathrm{~K})$. & $\begin{array}{l}\text { Elogia: A professora porque ajuda e é legal. } \\
\text { Sugere: Mais futebol, pega-pega, mais tempo de aula. }\end{array}$ \\
\hline 17 (L.) & $\begin{array}{l}\text { Elogia: A forma como é feita as aulas. } \\
\text { Sugere: Mais tempo e aprender mais jogos. }\end{array}$ \\
\hline 18 (L.) & $\begin{array}{l}\text { Elogia: Registros diários. } \\
\text { Sugere: Ter mais pesquisas. } \\
\text { Critica: Brigas. }\end{array}$ \\
\hline 19 (L.) & Não fez. \\
\hline 20 (M.) & $\begin{array}{l}\text { Elogia: Aulas práticas e teóricas. } \\
\text { Sugere: Mais tempo de aula e conhecer mais jogos. }\end{array}$ \\
\hline
\end{tabular}




\begin{tabular}{|l|l|}
\hline 21 (N.C.) & $\begin{array}{l}\text { Elogia: Aulas práticas. } \\
\text { Sugere: Ter mais jogos infantis, ex.: mamãe polenta. } \\
\text { Crítica: Aulas teóricas. }\end{array}$ \\
\hline 22 (N.M.) & Não fez. \\
\hline 23 (N.) & $\begin{array}{l}\text { Elogia: Jogos de saltar. } \\
\text { Sugere: Jogos menos demorados e mais futebol. }\end{array}$ \\
\hline
\end{tabular}

4e) Aula 12: Observações da professora sobre os registros dos alunos Nota-se que os alunos têm se empenhado mais na produção dos registros. Considero, de maneira geral, que os fatores que contribuem para isso são:

1. já se acostumaram a fazer os registros como tarefas de casa;

2. os critérios de avaliação exposto aos alunos estão mais simplificados e aproximam-se da linguagem dos alunos;

3. compreenderam que a utilização de outras formas de linguagem diminui o trabalho de escrever e possibilita a expressão da criatividade;

4. as propostas de aulas práticas mostram-se significativas para os alunos.

4f) Aula 18: Diário da aula

Após essa etapa, perguntei aos alunos o que acharam dos resultados apresentados na primeira parte do projeto em seus portfólios. Eu queria saber se haviam lido em casa e muitos responderam que gostaram dos resultados. Porém, a aluna 22 (N.C.) surpreendeu com a sua resposta: Eu achei que ele [o portfólio] mostrou uma avaliação mais justa.

4g) Aula 18: Observações da professora sobre os registros dos alunos Percebe-se em alguns registros que o aluno aguarda os meus comentários para ver o que achei da sua produção.

4h) Aula 20: Observações da professora sobre os registros dos alunos Percebi que o formato da aula por meio de tarefas organizadas em circuito foi significativo para os alunos, pois na maioria dos registros dos alunos essa organização dos jogos executados foi expressa com muitos detalhes.

4i) Aula 21: Observações da professora sobre os registros dos alunos 
Percebo nos registros que, para os alunos, estabelecer relações com outras informações de fora da escola é uma tarefa difícil. Essa dificuldade ocorre, talvez porque não conseguem entender a importância de buscar outras informações para ampliar seus conhecimentos sobre os conteúdos propostos em aula.

4j) Aula 22: Observações da professora sobre os registros dos alunos

Nessa aula apareceram registros que impressionaram pela organização das idéias expostas. Os alunos relataram as estratégias escolhidas por seu grupo no jogo, as dicas para melhorar e os problemas que enfrentaram com os colegas. Percebe-se que eles usam com mais tranqüilidade a escrita e o desenho, e outros até se arriscam a utilizar outras formas de registro, como cartazes, colagem, pesquisas e maquetes. Eu considero que nesse momento os alunos estavam começando a entender a proposta, pois eles demonstraram que a prática dos registros era uma forma de sistematizar o que aprenderam e aquilo em que sentiram dificuldade.

Os registros apontam que os alunos foram desenvolvendo algumas habilidades ao longo do projeto, como refletir sobre o que fazem e expor o que pensam; melhorou a qualidade de sua participação em aula, opinando e sabendo ouvir nos momentos de discussão em grupo.

\section{I) Aula 24: Diário da aula}

Observo nos registros que as discussões realizadas na roda de conversa organizam as idéias, sistematizam o que os alunos aprenderam e estabelecem novas relações, pois as discussões realizadas nesses momentos da aula são sempre mencionadas pelos alunos.

4m) Aula 25: Diário da aula

O espaço em que ocorreu essa aula (sala de leitura) auxiliou a manter os alunos concentrados na atividade proposta, possibilitando situações de uns auxiliarem os outros.

TABELA 49 - Quarta pergunta norteadora - Observações sobre a segunda coleta do portfólio dos alunos 


\begin{tabular}{|c|c|}
\hline Alunos & Avaliação das aulas realizada pelos alunos \\
\hline 1 (A.B.) & $\begin{array}{l}\text { Elogia: Fazer registros. } \\
\text { Sugere: Mais aulas práticas. } \\
\text { Critica: Aulas teóricas. }\end{array}$ \\
\hline $3(\mathrm{C})$. & $\begin{array}{l}\text { Elogia: o capricho da professora para preparar a aulas diferentes. } \\
\text { Critica: Aulas teóricas. }\end{array}$ \\
\hline $4(\mathrm{~F})$. & $\begin{array}{l}\text { Elogia: Aulas livres. } \\
\text { Critica: Aula teórica. } \\
\text { Sugere: Mais aulas práticas. }\end{array}$ \\
\hline $5(\mathrm{~F})$. & $\begin{array}{l}\text { Elogia: Quando a prof. vê, lê e comenta os registros dos alunos. } \\
\text { Sugere: Mais cooperação nos trabalhos em grupo. }\end{array}$ \\
\hline 6-G.B. & $\begin{array}{l}\text { Elogia: as pessoas que gostam de jogar. } \\
\text { Critica: desrespeito às regras. } \\
\text { Sugere: criar mais jogos. }\end{array}$ \\
\hline 7 (G.R.) & $\begin{array}{l}\text { Elogia: Os jogos. } \\
\text { Sugere: Mais tempo para a aula. }\end{array}$ \\
\hline 8 (G.) & $\begin{array}{l}\text { Elogia: As aulas práticas. } \\
\text { Sugere: Jogos com materiais mais diversificados. }\end{array}$ \\
\hline 9 (I.C.) & $\begin{array}{l}\text { Elogia: Transformar jogos. } \\
\text { Sugere: Mais aulas de saltar. }\end{array}$ \\
\hline 10 (I.C.) & Elogia: As aulas práticas. \\
\hline 11 (I.) & $\begin{array}{l}\text { Elogia: A professora. } \\
\text { Sugere: Mais jogos e dança. } \\
\text { Critica: Poucas pesquisas e bagunça. }\end{array}$ \\
\hline 14 (J.B.) & $\begin{array}{l}\text { Elogia: Jogos. } \\
\text { Sugere: Mais respeito às regras. } \\
\text { Critica: Brigas. }\end{array}$ \\
\hline 15 (J.P.) & $\begin{array}{l}\text { Elogia: Dedicação da professora. } \\
\text { Sugere: Ter mais cooperação e respeito às regras. } \\
\text { Critica: Falta de atenção e conversas paralelas. }\end{array}$ \\
\hline
\end{tabular}




\begin{tabular}{|l|l|}
\hline 16 (K.) & $\begin{array}{l}\text { Elogia: Todas as aulas. } \\
\text { Sugere: Mais tempo de jogo. }\end{array}$ \\
\hline 17 (L.) & $\begin{array}{l}\text { Elogia: A ajuda da professora aos amigos. } \\
\text { Sugere: Mais jogos e brincadeiras com corda. }\end{array}$ \\
\hline 18 (L.) & $\begin{array}{l}\text { Elogia: } \text { Registros diários. } \\
\text { Sugere: Ter mais oportunidade para montar jogos. } \\
\text { Critica: } \text { Conversas paralelas. }\end{array}$ \\
\hline 19 (L.) & $\begin{array}{l}\text { Elogia: Esforço da professora. } \\
\text { Sugere: Mais aulas práticas. }\end{array}$ \\
\hline 20 (M.) & $\begin{array}{l}\text { Elogia: Aulas práticas. } \\
\text { Sugere: Mais tempo de aula. }\end{array}$ \\
\hline 22 (N.M.) & $\begin{array}{l}\text { Elogia: Aulas práticas, as dicas dadas pela professora, o cumprimento } \\
\text { das regras. } \\
\text { Sugere: Ter mais jogos e menos registros. }\end{array}$ \\
\hline 23 (N.) & $\begin{array}{l}\text { Elogia: Os registros diferentes e as pesquisas dos amigos. } \\
\text { Sugere: Fazer mais pesquisas. }\end{array}$ \\
\hline
\end{tabular}


ANEXO VII Indícios da quinta pergunta norteadora: O portfólio indicou as dificuldades da professora no processo de ensino $\mathrm{e}$ aprendizagem?

5a) Aula 1: Observações da professora sobre os registros dos alunos

Percebi que os registros dos alunos são realizados sempre por meio da escrita; poucos usam outros materiais, talvez porque não sabem como fazer isso! Não têm modelos ou referências para fazerem diferente.

TABELA 50 - Quinta pergunta norteadora - Aula 2 - Observações sobre os registros dos alunos

18 (L.) $\quad$ A dificuldade foi passar para o outro time. (...) Eu não entendi por que os amigos falaram que não pode passar a bola.

TABELA 51 - Quinta pergunta norteadora - Aula 2 - Observações sobre os registros dos alunos

23 (N.) Eu não entendi por que não pode jogar a bola pro amigo no piquebandeira?

TABELA 52 - Quinta pergunta norteadora - Aula 5 - Observações sobre os registros dos alunos

23 (N.) Senti dificuldade no jogo floresta porque eu não sabia que no jogo tinha que esperar o pegador falar já.

5e) Aula 8: Diário da aula

Admito que a insegurança e a falta de maturidade com esse tipo de trabalho me fizeram conduzir as ações dos alunos.

5f) Aula 9: Observações da professora sobre os registros dos alunos

Ao olhar os portfólios dos alunos, fiquei surpresa ao ver que 15 alunos não haviam entregado, e os outros alunos que entregaram fizeram o registro sem contemplar os critérios combinados na aula.

5g) Aula 9: Observações da professora sobre os registros dos alunos 
Percebo que quando os alunos fazem os registros de maneira incompleta ou, simplesmente não os trazem, isso pode ser conseqüência da forma como as explicações estão sendo apresentadas aos alunos. É necessário tomar cuidado com a forma que se usa para explicar tarefas de casa, pois não se está atingindo a compreensão dos alunos. Muitos saem da aula sem entender ao certo o que devem fazer.

5h) Aula 10: Observações da professora sobre os registros dos alunos Sinto falta de discutir com alguém da área as estratégias que tenho utilizado na prática do portfólio. Gostaria muito de dividir minhas dúvidas e tomar decisões em conjunto com alguém. Talvez isso diminuísse a minha ansiedade e as atitudes impensadas.

5i) Aula 11: Observações da professora sobre os registros dos alunos Percebi que os critérios de avaliação fornecidos aos alunos estavam com uma linguagem difícil para eles entenderem o que seria avaliado e quais itens deveriam ter em seu portfólio.

5j) Aula 16: Diário da aula

Percebi que os registros que os alunos esquecem de fazer e acabam entregando atrasados são compostos apenas de registros escritos e poucos são os critérios contemplados. 
ANEXO VIII Indícios da sexta pergunta norteadora: O portfólio possibilitou à professora conhecimento sobre como melhorar as suas dificuldades?

6a) Aula 9: Observações da professora sobre os registros dos alunos A comunicação entre professora e alunos precisava ser melhorada, ou seja, as explicações precisavam ser mais claras e adequadas às características dos alunos.

A iniciativa que escolhi para melhorar esse problema foi escrever orientações individuais sobre o que eles precisavam melhorar nos registros inseridos em seu portfólio. Utilizava papeizinhos coloridos que eram grudados nos registros para chamar a atenção dos alunos sobre os critérios que estavam faltando e o que eles precisavam melhorar.

6b) Aula 11: Diário da aula

Após a exposição dos elementos que os alunos e a professora consideraram que melhoraram e outros que precisavam melhorar, construímos uma lista de itens que poderiam melhorar as dificuldades do grupo, como segue:

\section{O que fazer para melhorar?}

- Correr mais;

- saltar melhor;

- chutar com mais mira;

- aprender a rebater;

- aprender a receber melhor a bola ou peteca;

- pesquisar mais;

- lembrar de fazer os registros;

- escrever o que sentiu dificuldade;

- participar mais das discussões;

- resolver problemas com os amigos sem ajuda da professora;

- prestar atenção nas discussões da aula. 
Obs.: Considero que esse tipo de esquema norteia os alunos com relação ao trabalho, pois retoma os objetivos, define os itens que distinguem os avanços, as dificuldades e o que fazer para melhorar.

6c) Aula 11: Observações da professora sobre os registros dos alunos Percebi que os critérios de avaliação fornecidos aos alunos estavam com uma linguagem difícil para eles entenderem o que seria avaliado nos registros inseridos no portfólio. A estratégia utilizada para melhorar esse problema foi procurar outra maneira de fornecer os critérios: por meio de perguntas que os alunos pudessem responder, construindo seu registro de forma mais completa. Tive a idéia de construir essas perguntas atreladas ao objetivo que tinha para atingir como empreendimento final no projeto, relacionado à construção de um livro de jogos para presentear a um amigo. Desse modo, as perguntas ficaram da seguinte maneira:

1-Como você ensinaria a um amigo o jogo...?

2-Quando você e seus amigos estavam jogando..., você sentiu alguma dificuldade?

3-Qual foi essa dificuldade?

4-O que você fez, ou é possível ser feito, para melhorar a dificuldade?

5-Durante o jogo... aconteceu algum problema e de que forma você e o grupo resolveram?

6d) Aula 13: Diário da aula

Após os alunos lerem os meus apontamentos em seu registro, a estratégia escolhida foi fazer coletivamente esse registro, contemplando os critérios combinados na aula e eu atuando como escriba. A intenção era fornecer aos alunos sugestões sobre como fazer um registro de forma escrita, desenhada e com colagem de figuras pesquisadas em livros e revistas.

TABELA 53 - Sexta pergunta norteadora - Aula 13 - Observações sobre os registros dos alunos

1 (A.B.) Identifica o jogo realizado e cita que a professora ensinou como fazer o registro diário de Educação Física. 


\begin{tabular}{|l|l|}
\hline Expõe que as dicas mais importantes que aprendeu nessa aula foram: \\
prestar mais atenção na aula; não olhar para os problemas que \\
acontecem entre os jogadores da outra equipe. \\
Disse que o jogo ficou mais fácil sendo jogado com menos pessoas. \\
Também cita que fazer o registro de maneira coletiva foi bom para \\
quem tinha dúvidas. \\
Utilizou o desenho para explicar com jogou.
\end{tabular}

6e) Aula 16: Diário da aula

Percebi que nos registros que os alunos esquecem de fazer e acabam entregando atrasados poucos são os critérios contemplados.

Pergunto-me o que preciso fazer para melhorar essa situação.

Resolvi retomar a discussão com os alunos sobre por que é importante registrar. Três pontos foram levantados pelos próprios alunos:

1) para saber e lembrar o que aprendeu ou não;

2) para melhorar aquilo em que sentiu dificuldade;

3) para ajudar a professora a avaliar o que deu certo ou errado na aula. 